CLAUDIO MENDONÇA BRAGA

\title{
O NOVO MARCO REGULATÓRIO COMO INSTRUMENTO PARA A EFETIVAÇÃO DE POLÍTICAS PÚBLICAS DE DEMOCRATIZAÇÃO DO ACESSO À EDUCAÇÃO SUPERIOR
}

\author{
Tese de Doutorado
}

Orientador: Professor Emérito Dalmo de Abreu Dallari

FACULDADE DE DIREITO DA UNIVERSIDADE DE SÃO PAULO

SÃO PAULO

2013 
CLAUDIO MENDONÇA BRAGA

\section{O NOVO MARCO REGULATÓRIO COMO INSTRUMENTO PARA A EFETIVAÇÃO DE POLÍTICAS PÚBLICAS DE DEMOCRATIZAÇÃO DO ACESSO À EDUCAÇÃO SUPERIOR}

Tese de Doutorado apresentada no Programa de Pós-Graduação Stricto Sensu da Faculdade de Direito da Universidade de São Paulo, como requisito para a obtenção do título de Doutor em Direito do Estado, sob a orientação do Professor Emérito Dalmo de Abreu Dallari.

FACULDADE DE DIREITO DA UNIVERSIDADE DE SÃO PAULO

SÃO PAULO

2013 
A minha mãe e educadora,

Oswalda Rodrigues Mendonça,

por ocasião de sua aposentadoria, após

52 anos ininterruptos como professora em sala de aula. 
"O ser humano só pode tornar-se ser humano pela educação. Ele não é nada além do que aquilo que a educação faz dele."

"Der Mensch kann nur Mensch werden durch Erziehung. Er ist nichts, als was die Erziehung aus ihm macht."

(Immanuel Kant, Über Pädagogik, Königsberg: Friedrich Theodor Rinf, 1803, p. 11) 


\section{AGRADECIMENTOS}

Os presentes agradecimentos não se restringem às pessoas citadas, mas são estendidos a todos que, de alguma forma, contribuíram para a elaboração deste trabalho. Escuso-me, desta maneira, pelas omissões causadas pela traição da memória.

Primeiramente, agradeço a meu orientador, Professor Dalmo de Abreu Dallari, jurista notável por sua brilhante trajetória, na qual soube, como poucos professores e advogados, conciliar teoria e prática, com sua sólida formação cultural e profunda preocupação social. Seu exemplo certamente me acompanhará por toda a vida, em termos acadêmicos e pessoais.

Agradeço também, de forma efusiva, aos professores Gilberto Bercovici e Sebastião Botto de Barros Tojal, pelas importantes críticas e sugestões que fizeram, por ocasião do exame de qualificação, que, certamente, contribuíram muito para o resultado final deste trabalho.

Apresento, também, meu cordial agradecimento à Professora Maria Paula Dallari Bucci, verdadeira fonte de interpretação autêntica da regulação da educação superior, pelo apoio, críticas e sugestões que foram muito importantes no presente trabalho.

Agradeço também ao Professor Virgílio Afonso da Silva, por contribuir com minha iniciação científica, por meio da orientação no meu curso de Mestrado. Certamente, muitas das lições que aprendi com ele colaboraram para esse novo passo na minha vida acadêmica.

Ao jovem acadêmico Reinaldo Ghesso, novo aluno do programa de Mestrado em Direito do Estado na Faculdade de Direito da USP, agradeço pela colaboração durante a pesquisa e na atividade docente. Certamente, ele será um brilhante professor e pesquisador em futuro próximo. 
Agradeço, outrossim, ao amigo Danilo Tavares da Silva, companheiro de momentos acadêmicos e pessoais, pelas importantes críticas feitas a respeito do trabalho e pelas palavras de estímulo nos momentos difíceis.

Por meio das Arcadas do Largo de São Francisco, local de imensa inspiração, apresento meus agradecimentos a todos os colegas, professores e funcionários, que foram fundamentais para o meu desenvolvimento pessoal e acadêmico durante o Bacharelado, Mestrado e Doutorado.

Agradeço à Universidade São Judas Tadeu, na pessoa do Diretor da Faculdade de Direito, Professor Fernando Herren Aguillar, pela confiança depositada e pelo estímulo proporcionado em um ambiente saudável de prática acadêmica.

Fundamental também é o agradecimento a todas as pessoas com quem tive a honra de participar, em algum momento, da construção do marco regulatório da educação superior, em especial: Fernando Haddad, Henrique Paim, Luis Fernando Massonetto, João Paulo Bachur, Ronaldo Mota, Reynaldo Fernandes, Dilvo Ilvo Ristoff, Dirceu do Nascimento, Paulo Wollinger, José Rubens Rebelatto, Marta Wendel Abramo, Paula Branco de Mello, Iguatemy Maria de Lucena Martins, Carolina Gabas Stucchi, Frederico Normanha Ribeiro de Almeida, Maria Aparecida Azevedo de Abreu, Ademir Picanço de Figueiredo, Patricia Parra Ferreira dos Santos, Mauro César Santiago Chaves, Samuel Martins Feliciano, Simone Horta Andrade, Jaime Giolo, Gustavo Henrique Moraes, Karin Maria Pflaune Schoen, Maria Lúcia Rehder de Andrade, Ricardo Corrêa Coelho, entre muitos outros.

Agradeço também a minha enteada Nara Torrecilha, jovem - e já experiente acadêmica, pelas contribuições e incentivo em vários momentos desta jornada acadêmica.

Agradeço à memória de meu pai, Samuel Braga, que apreciaria muito esse trabalho, e a minha mãe, Oswalda Rodrigues Mendonça, professora que dedicou a vida à educação fundamental. A eles devo as bases de minha formação cultural e moral, que carregarei por toda a vida.

Agradeço, especialmente, a minha companheira Thelma Torrecilha, pelo incentivo, ajuda, compreensão e carinho nos momentos mais difíceis do desenvolvimento desta tese. Sem o seu apoio, esse empreendimento não poderia ter sido realizado. 
Por fim, agradeço a meu filho Gabriel Torrecilha Braga, pelo estímulo proveniente de cada sorriso, comentário ou brincadeira, que tornam a vida mais bonita e iluminada, e me dá a esperança de que podemos sonhar com um mundo melhor! 


\section{RESUMO}

O presente estudo tem por objeto o estudo do marco regulatório da educação superior e de sua relação com a garantia de acesso à educação superior no Brasil. Para tanto, o direito à educação é estudado para que seja estabelecida sua relação com o direito da educação - um conjunto de normas jurídicas que disciplinam a atividade educacional. Posteriormente, o direito da educação superior é analisado, com destaque na necessidade de autorização estatal e avaliação de qualidade. São estudados, também, os fundamentos da atividade regulatória do estado e a natureza jurídica da atividade educacional. Em seguida, é estudado o sistema regulatório da educação superior no Brasil, por meio de processo administrativo que, após a realização de avaliação de qualidade, expede atos administrativos regulatórios. Por fim, é analisada a relação da regulação da educação superior com políticas públicas de garantia de acesso à educação superior.

Palavras-chave: Direito à educação. Educação superior. Avaliação da educação superior. Regulação da educação superior. 


\section{ZUSAMMENFASSUNG}

Diese These stellt sich die Aufgabe, das Studium der Regulierung der Hochschulbildung und ihre Beziehung zur Bereitstellung des Zugangs zu höherer Bildung in Brasilien. Daher wird das Recht auf Bildung und ihre Beziehung mit dem pädagogische Recht untersucht sein. Anschließend wird das Recht der Hochschulen analysiert, die die Notwendigkeit für staatliche Zulassung und Qualitätssicherung. Die Fundamente der regulierung aktivität des Staates und der Rechtsnatur des erzieherischen Tätigkeit werden ebenfalls untersucht.. Dann wird das regulatorische System der höheren Bildung in Brasilien durch Verwaltungsverfahren studiert, durch die Beurteilung und Expedition von regulatorischen Verwaltungsakte. Schließlich untersuchten wir die Beziehung der Regulierung der Hochschulbildung mit der Politik, den Zugang zu höherer Bildung.

Stichwörter: Recht auf Bildung. Hochschulbildung. Hochschulbildung Auswertung. Verordnung der Hochschulbildung. 


\begin{abstract}
This thesis has as its object the study of the regulation of higher education and its relation to the provision of access to higher education in Brazil. Therefore, the right to education is studied for their relationship to be established with the right education - a set of legal rules governing the educational activity. Subsequently, the right of higher education is analyzed, highlighting the need for state authorization and quality assessment. The foundations of the regulatory activity of the state and the legal nature of the educational activity are also studied. Then, the regulatory system of higher education in Brazil is studied by means of administrative procedure, by assessing, and expedition of regulatory administrative acts. Finally, we analyzed the relationship of regulation of higher education with policies ensuring access to higher education.
\end{abstract}

Keywords: Right to education. Higher education. Higher education evaluation. Regulation of higher education. 


\section{SUMÁRIO}

INTRODUÇÃO

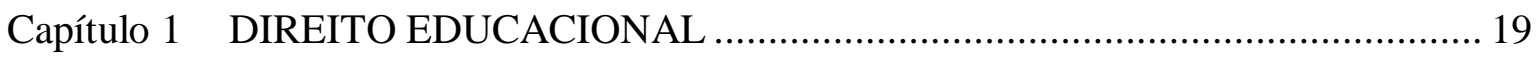

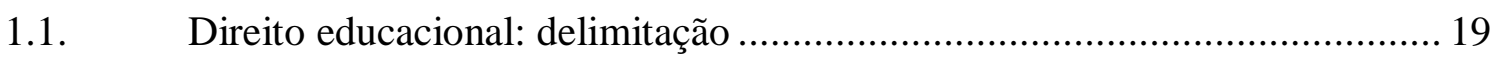

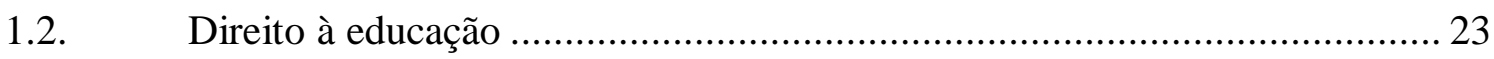

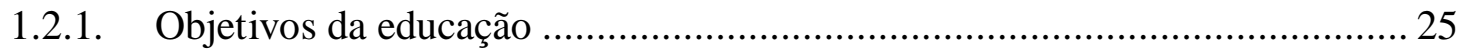

1.2.2. Educação como direito fundamental social............................................. 28

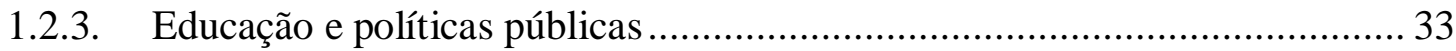

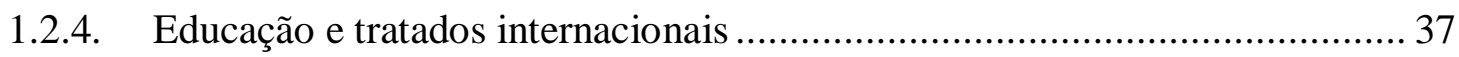

1.2.5. Tratamento constitucional do direito à educação ...................................... 40

1.2.5.1. Evolução constitucional do tratamento da educação ........................... 40

1.2.5.2. Educação na Constituição de 1988 .................................................... 43

1.2.6. Educação como direito público subjetivo ................................................. 48

1.2.7. Educação e desenvolvimento ................................................................ 49

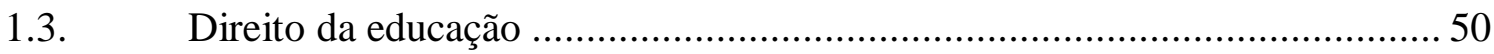

1.3.1. Lei de Diretrizes e Bases da Educação Nacional (LDB) ............................ 51

1.3.1.1. Sistemas de ensino estabelecidos pela LDB ................................... 52

1.3.1.2. Níveis e modalidades de educação estabelecidos na LDB ................... 57

1.3.1.3. Financiamento público de instituições educacionais privadas .............. 58

1.3.2. Plano Nacional de Educação .................................................................. 59

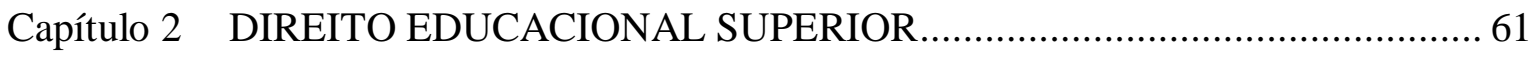

2.1. Educação Superior no Brasil: evolução histórica de seu tratamento jurídico 61

2.2. Educação Superior na Constituição de 1988 …......................................... 67

2.2.1. Liberdade à iniciativa privada e avaliação de qualidade pelo Poder Público 67

2.2.2. Universidades, centros universitários e autonomia universitária .................. 69

2.3. Educação superior na Lei de Diretrizes e Bases da Educação ...................... 75

2.3.1. Conceitos fundamentais relativos à educação superior .............................. 76

2.3.1.1. Conceitos relativos a instituições educacionais ................................. 77

2.3.1.2. Conceitos relativos a cursos superiores.......................................... 79 
2.3.1.3. Conceitos relativos a docentes e alunos

2.3.2. Garantia de padrão de qualidade e regulação da educação superior 83

2.4. Plano Nacional de Educação e as metas relativas à educação superior 85

Capítulo 3 FUNDAMENTOS DA REGULAÇÃO DA EDUCAÇÃO SUPERIOR....... 90

3.1. Natureza jurídica da atividade educacional ........................................... 90

3.2. Fundamentos da atividade regulatória do Estado .................................... 101

3.2.1. Regulação: administração pública ordenadora e fomento .......................... 103

3.2.2. Regulação econômica e regulação social................................................ 105

3.3. Análise de impacto regulatório - AIR .................................................... 109

3.3.1. Programa de Fortalecimento da Capacidade Institucional para Gestão em Regulação - PRO-REG

3.3.2. Análise de impacto regulatório na educacional superior

3.4. Mecanismos de controle da atividade educacional pela sociedade e pelas corporações profissionais 116

3.5. Panorama da regulação da educação superior no mundo 119

Capítulo 4 MARCO REGULATÓRIO DA EDUCAÇÃO SUPERIOR ...................... 125

4.1. Marco regulatório da educação superior: delimitação ................................ 125

4.2. Expansão da educação superior no Brasil ................................................. 129

4.3. Sistema Nacional de Avaliação da Educação Superior (SINAES) ............. 131

4.4. Aparelhamento do Estado brasileiro para a atividade regulatória da educação

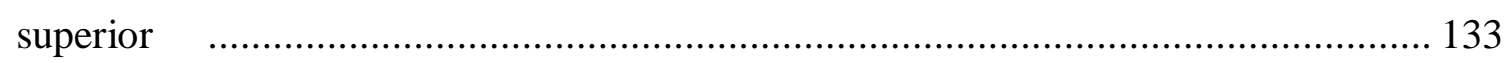

4.5. Regulamentação infralegal da atividade regulatória da educação superior . 133

4.5.1. Decreto $\mathrm{n}^{\mathrm{o}}$ 5.773, de 9 de maio de 2006 ................................................. 134

4.5.2. Portaria Normativa/MEC no 40, de 12 de dezembro de 2007 .................... 135

4.6. Posicionamento do Judiciário a respeito do novo marco regulatório ........... 136

4.7. Projeto de Lei $n^{\circ} 4.372 / 2012$ : criação Instituto Nacional de Supervisão e Avaliação da Educação Superior - INSAES...................................................... 138

\section{Capítulo 5 PROCEDIMENTO ADMINISTRATIVO DE REGULAÇÃO DA}

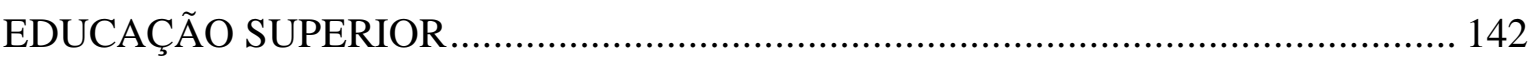

5.1. Procedimentalização da atividade administrativa.................................... 142

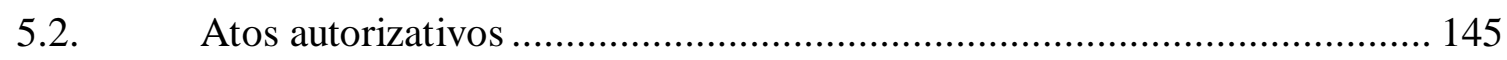


5.3. Processo administrativo eletrônico: o Sistema e-MEC.............................. 149

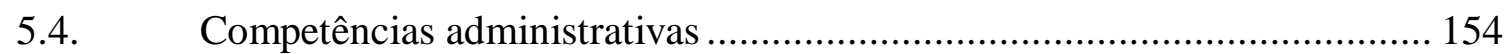

5.4.1. Ministro de Estado da Educação ............................................................ 155

5.4.2. Conselho Nacional de Educação (CNE) ................................................ 155

5.4.3. Comissão Nacional de Avaliação da Educação Superior (CONAES) ........ 157

5.4.4. Instituto Nacional de Estudos e Pesquisas Educacionais Anísio Teixeira

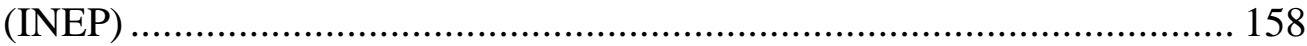

5.4.5. Secretaria de Regulação e Supervisão da Educação Superior (SERES) ...... 160

5.4.6. Síntese do sistema de competências administrativas na regulação da educação

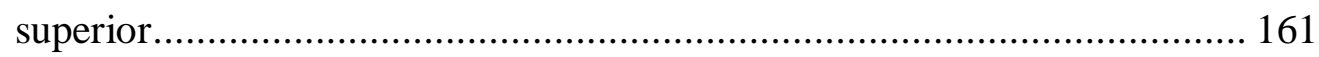

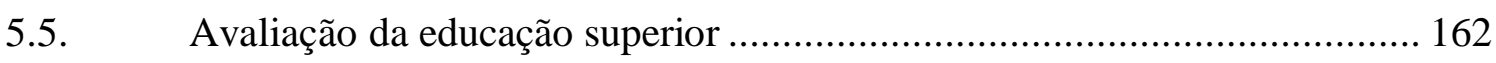

5.5.1. Elementos fundamentais para avaliação da educação superior ................... 163

5.5.1.1. Exame Nacional de Desempenho dos Estudantes (ENADE) .............. 163

5.5.1.2. Banco de avaliadores (Basis) ........................................................ 165

5.5.1.3. Instrumentos de avaliação .......................................................... 167

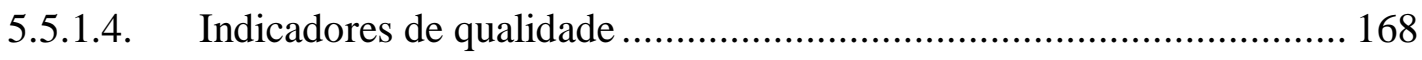

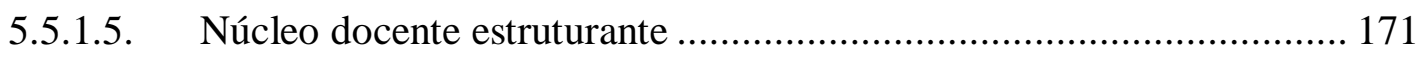

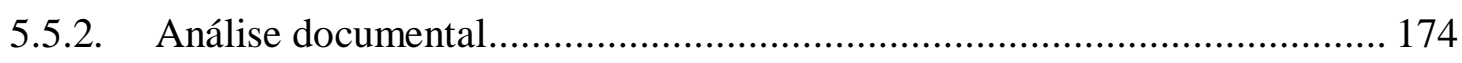

5.5.2.1. Análise documental nos processos de credenciamento e recredenciamento

5.5.2.2. Análise documental nos processos de autorização, reconhecimento e

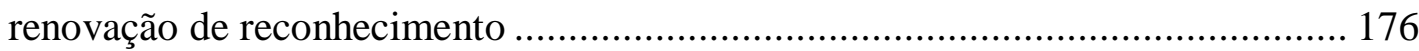

5.5.2.3. Decisão e recurso na fase de análise documental ............................. 177

5.5.3. Dispensa da avaliação in loco, visitas por amostragem e possibilidade de prorrogação da validade de atos autorizativos....................................... 178

5.5.4. Avaliação in loco realizada pelo INEP .................................................. 180

5.5.4.1. Impugnação do resultado da avaliação............................................. 182

5.5.4.2. Avaliação como referencial para a regulação em sentido estrito......... 183 5.6. Regulação em sentido estrito da educação superior: decisão administrativa e

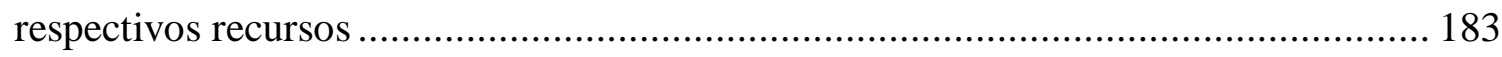

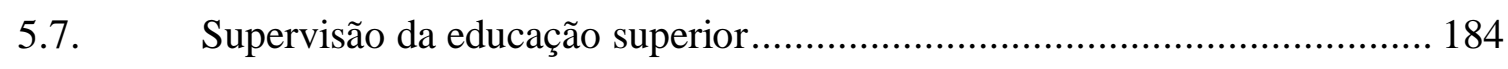

5.8. Termo de saneamento de deficiências e protocolo de compromisso........... 187 


\section{Capítulo 6 REGULAÇÃO COMO GARANTIA DO DIREITO À EDUCAÇÃO}

SUPERIOR 190

6.1. Regulação e sua relação com as políticas públicas de democratização do

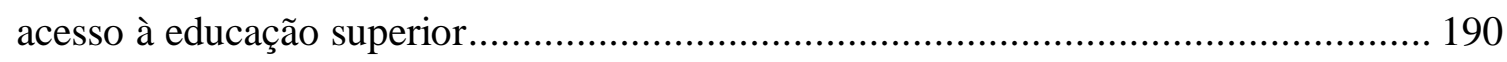

6.1.1. Programa Universidade para Todos (ProUni) ........................................ 191

6.1.2. Fundo de Financiamento ao Estudante do Ensino Superior (FIES) ............ 194

6.2. Regulação da educação superior e diminuição de desigualdades regionais na

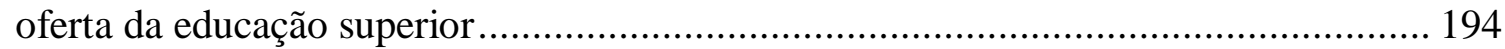

6.3. Regulação da educação superior e sua relação com políticas de efetivação do

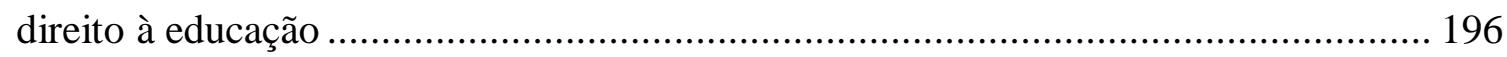

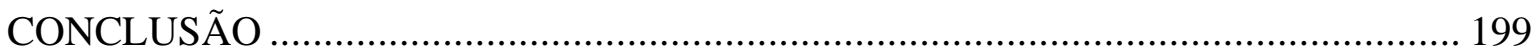

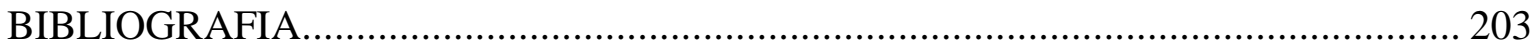

ANEXO: Legislação e normas pertinentes à regulação da educação superior................. 216 


\section{INTRODUÇÃO}

A presente tese visa ao estudo do novo marco regulatório como instrumento para a efetivação de políticas públicas de democratização do acesso à educação superior. Entende-se por novo marco regulatório da educação superior uma série de inovações normativas destinadas a dotar o Poder Público de mecanismos para efetivar o dispositivo contido no artigo 209 da Constituição, que condiciona o desempenho da atividade educacional pela iniciativa privada à avaliação de qualidade e autorização estatal.

Dessa maneira, o presente trabalho busca estabelecer a relação existente entre a consolidação desse marco regulatório e a instrumentalização do Poder Público para a implementação de políticas públicas de acesso à educação superior, como salienta Maria Paula Dallari Bucci:

"O direito à educação, inequivocamente estruturante da cidadania, segundo os arts. $6^{\circ}$ e 205 e seguintes da Constituição, não se realiza senão nos termos do direito da educação, isto é, segundo o conjunto de normas (e a aplicação que delas se faz) que concretamente regem o funcionamento das instituições educacionais de nível superior”. ${ }^{1}$

O presente estudo procura analisar em que medida a instituição do marco regulatório pode contribuir com a efetivação do direito à educação superior no país, estabelecendo a relação entre o direito $d a$ educação superior com o direito à educação superior, com a consciência de que o primeiro se trata de meio para que seja atingido o segundo, como fim.

Para a consecução do objetivo dessa pesquisa, é preciso estudar o conteúdo e a estrutura normativa do direito à educação, bem como os fundamentos da atividade regulatória do Estado, como ferramentas teóricas para analisar e sistematizar a regulação da educação superior, a fim de estabelecer a sua relação com a efetividade do direito à educação superior.

A presente tese apresenta questão original à ciência jurídica brasileira, uma vez que tem por objeto de análise sistemática do novo marco regulatório da educação superior

\footnotetext{
${ }^{1}$ Maria Paula Dallari Bucci, "O art. 209 da Constituição 20 anos depois. Estratégias do Poder Executivo para a efetivação da diretriz da qualidade da educação superior", in Gustavo Binenbojm / Daniel Sarmento / Cláudio Pereira de Souza Neto (orgs.). Vinte Anos da Constituição Federal de 1988. Rio de Janeiro: Lumen Juris, 2008, p. 786.
} 
no Brasil, que está com sua implementação em curso e, dessa maneira, não possui ainda significativo tratamento doutrinário no campo jurídico. A doutrina relativa à regulação da educação superior - compreendendo avaliação, regulação em sentido estrito e supervisão é encontrada na área da Educação, na grande maioria dos casos, sem o enfoque adequado nos aspectos normativos.

Em grande medida, a regulação da educação superior no Brasil não foi tratada pelo mundo jurídico. Enquanto a área da regulação econômica desenvolveu-se muito nas últimas décadas, no que se refere a serviços públicos delegados por meio de concessão ou permissão, no que diz respeito à educação superior, não houve o mesmo grau de desenvolvimento. Uma explicação possível é o fato da atividade há muito tempo ser livre à iniciativa privada, sem que houvesse uma preocupação em se aprofundar o tratamento sobre seu regime regulatório. Outra razão pode ser o fato de não ter sido criada uma agência reguladora específica, como no caso dos serviços delegados, a demandar uma doutrina apta a fixar seus marcos teórico-normativos.

O fato é que a regulação da educação superior, cujo marco regulatório é recente, necessita do tratamento jurídico doutrinário aprofundado. Nessa linha, o presente trabalho busca realizar a consolidação teórica do novo marco regulatório da educação superior, não por meio de um viés tecnicista e formalista, tendo a atividade regulatória com um fim em si mesma, mas à luz de possibilitar a instrumentalização do Estado para a busca da efetivação do direito fundamental à educação.

Portanto, o estudo sistemático do sistema regulatório da educação superior, como dimensão do Direito Educacional - ramo do direito em fase de consolidação constitui-se como contribuição original à ciência jurídica brasileira, pois estabelece a relação entre o direito $d a$ educação (conjunto de regras que disciplinam a atividade estatal e de agentes particulares em matéria educacional) para a garantia do direito à educação (direito fundamental, de cunho social, que garante a todas as pessoas o pleno desenvolvimento de suas potencialidades).

É importante partirmos do pressuposto de que a educação superior ainda é restrita a uma pequena parcela da população. Desde o início de sua evolução, o aspecto elitista da educação superior no Brasil está marcadamente presente. Quando surgiram os cursos superiores no país, no século XIX, havia uma forte relação entre o ensino estatal e o monopólio da formação de determinadas profissões. Luiz Antônio Cunha aborda essa 
questão, afirmando que, na época, se acreditava que o aumento do número de diplomados poderia reduzir o "valor intrínseco do diploma, em termos de poder, prestígio e remuneração". ${ }^{2}$ Esse valor intrínseco do diploma é um fator cultural muito peculiar e forte no Brasil, que deve ser considerado na organização do sistema de regulação desse setor, bem como na formulação de políticas públicas.

A relevância desse estudo é demonstrada pela existência do seguinte desafio que se impõe ao país: garantir a efetividade do direito à educação superior, por meio da busca do estabelecimento de um padrão de ensino de qualidade, a ser acessível à população como um todo, e não garantidora de um privilégio consubstanciado no diploma, como no século XIX. Não será efetiva a inclusão de setores excluídos da sociedade em cursos ou instituições de baixa qualidade, pois isso não contribuiria para o objetivo emancipatório do direito à educação.

Pelos aspectos apresentados, a presente tese está estruturada em seis capítulos, cujos conteúdos seguem a seguir sucintamente descritos.

No Capítulo 1, buscaremos a delimitação do conceito de Direito Educacional, a partir do qual é realizada a análise do direito à educação. Para tanto, são abordados os objetivos da educação e a configuração desta como direito fundamental social, a ensejar a implementação de políticas públicas para sua efetivação. Analisaremos, também, o tratamento dado ao direito à educação por tratados internacionais e pela Constituição brasileira. Posteriormente, abordaremos o direito da educação, por meio do estudo de normas que disciplinam o sistema educacional brasileiro e estabelecem suas metas: a Lei de Diretrizes e Bases da Educação e o Plano Nacional de Educação.

O Capítulo 2 terá como objeto o Direito Educacional Superior, por meio do estudo da evolução histórica de seu tratamento jurídico, bem como da atual disciplina constitucional e legal, com ênfase nos seguintes aspectos: liberdade à iniciativa privada, avaliação de qualidade pelo Poder Público e autonomia universitária.

O Capítulo 3 apresentará os fundamentos da regulação da educação superior, a partir da análise de sua natureza jurídica e dos fundamentos da atividade regulatória do Estado. Será apresentada, também, a análise de impacto regulatório e a tentativa de sua

\footnotetext{
${ }^{2}$ Luiz Antônio Cunha, A universidade temporãa: o ensino superior, da Colônia à Era Vargas, 3. ed., São Paulo: UNESP, 2007, p. 86.
} 
implementação no Brasil por meio do Programa de Fortalecimento da Capacidade Institucional para Gestão em Regulação - PRO-REG, bem como sua relação com a educação superior. Além disso, serão tratados os mecanismos de controle da atividade educacional pela sociedade e pelas corporações profissionais e o panorama da regulação da educação superior no mundo.

O Capítulo 4 terá como objeto a institucionalização do marco regulatório da educação superior por meio da criação do Sistema Nacional de Avaliação da Educação Superior (SINAES) e do aparelhamento do Estado brasileiro para a atividade regulatória da educação superior, pela regulamentação infralegal da atividade regulatória da educação superior, em especial, pela edição do Decreto n ${ }^{0}$ 5.773, de 9 de maio de 2006, e da Portaria Normativa/MEC no 40, de 12 de dezembro de 2007. Além disso, será abordado o posicionamento do Judiciário a respeito do novo marco regulatório e serão tecidos comentários sobre o Projeto de Lei $\mathrm{n}^{\mathrm{o}} 4.372 / 2012$, que pretende criar o Instituto Nacional de Supervisão e Avaliação da Educação Superior - INSAES.

No Capítulo 5, o objeto de análise será a sistematização do procedimento administrativo de regulação da educação superior, com destaque no fenômeno da procedimentalização da atividade administrativa e no conceito de atos autorizativo. Em seguida, serão estudados com detalhe, os processos administrativos de avaliação, regulação e supervisão da educação superior, desenvolvidos eletronicamente no Sistema e-MEC.

Por fim, o Capítulo 6 buscará estabelecer a relação entre a regulação da educação superior e políticas públicas de democratização do acesso a este nível educacional: o Programa Universidade para Todos (ProUni) e o Fundo de Financiamento ao Estudante do Ensino Superior (FIES). Além disso, será analisado de que forma a regulação da educação superior pode contribuir para a diminuição de desigualdades regionais na sua oferta, bem como para efetivação do direito à educação. 


\section{Capítulo 1 DIREITO EDUCACIONAL}

\subsection{Direito educacional: delimitação}

Preliminarmente, uma vez que o presente trabalho vincula-se à área de Direito do Estado, convém adotarmos uma conceituação preliminar de "Estado". Dessa maneira, parte-se da definição de Dalmo de Abreu Dallari, que aborda aspectos jurídicos e não jurídicos do fenômeno. Para o autor, Estado é “a ordem jurídica soberana que tem por fim o bem comum de um povo em determinado território". 3

Dessa definição, pode-se extrair que a finalidade do Estado é buscar o bem comum. Embora se trate de conceito jurídico indeterminado, sua aplicação é determinável no plano concreto. Para tanto, interessante é trazer a contribuição do Papa João XXIII a respeito dessa definição: "O bem comum consiste no conjunto de todas as condições de vida social que consintam e favoreçam o desenvolvimento integral da personalidade humana."4

Não pode ser outra a conclusão dessa exposição preliminar: é dever do Estado propiciar ao ser humano a possibilidade do desenvolvimento integral de sua personalidade. Trata-se, portanto, de direito fundamental de alcance universal, conforme proclamado na Declaração Universal dos Direitos Humanos, de 1948, em seu artigo XXVI, que estabelece, em relação ao direito à educação, o ensino elementar obrigatório e gratuito, a generalização da instrução técnico-profissional e a igualdade de acesso ao ensino superior. ${ }^{5}$

O direito à educação é reconhecido como direito social pela Constituição de 1988, que, em seu artigo 205, estabelece a educação como direito de todos e dever do Estado e da família, bem como que será promovida e incentivada com a colaboração da sociedade. $\mathrm{O}$ mesmo dispositivo acrescenta que seus objetivos são o pleno desenvolvimento da pessoa, seu preparo para o exercício da cidadania e qualificação para

\footnotetext{
${ }^{3}$ Dalmo de Abreu Dallari, Elementos de Teoria Geral do Estado. 29. ed. São Paulo: Saraiva, 2010, p. 119.

${ }^{4}$ Papa João XXIII, Pacem in Terris (Encíclica, II, 58) apud Dalmo de Abreu Dallari, Elementos de Teoria Geral do Estado, p. 24.

${ }^{5}$ Cf. Fábio Konder Comparato, A afirmação histórica dos direitos humanos, 3. ed., São Paulo, Saraiva, 2003, p. 227.
} 
o trabalho. Trata-se, portanto, de direito social, integrante do rol de direitos e garantias fundamentais, assim reconhecido expressamente no artigo $6^{\circ}$.

Da mesma maneira, a educação mostra-se fundamental para a consecução dos objetivos da República Federativa do Brasil, estabelecidos no artigo $3^{\circ}$, pois, indubitavelmente, é instrumento imprescindível para: (a) construir uma sociedade livre, justa e solidária; (b) garantir o desenvolvimento nacional; (c) erradicar a pobreza e a marginalização e reduzir as desigualdades sociais e regionais; e (d) promover o bem de todos, sem preconceitos de origem, raça, sexo, cor, idade e quaisquer outras formas de discriminação.

Por essa razão, o estudo do Direito Educacional, que vem ganhando contornos doutrinários próprios, relaciona-se diretamente com a cidadania, ocupando um importante espaço no âmbito do direito público. A Constituição da República Federativa do Brasil dedicou uma seção à educação (artigos 205 a 214), estabelecendo, em síntese, seus princípios, suas garantias fundamentais e o arranjo institucional para a sua prestação. Dado o tratamento constitucional a respeito da educação, com o estabelecimento de princípios e regras, em grande medida, abstratas para a organização da atividade estatal nessa área, fazse necessária a instituição de uma normatização infraconstitucional apta a efetivar o direito à educação. É o que, no presente trabalho, se denomina direito da educação.

Nesse sentido, Jorge Miranda aponta para o caminho da autonomia do Direito Educacional, pois para ele, no interior do que constitui o que denomina "Constituição cultural", 6 "a região mais importante, de mais forte influência e mais pronta a ser autonomizada vem a ser a Constituição da educação". ${ }^{7}$ Partindo-se da posição de que o Direito Educacional é dotado de autonomia científica, Elias de Oliveira Motta aponta três formas de enfocar seu conceito:

“1) o conjunto de normas reguladoras dos relacionamentos entre as partes envolvidas no processo ensino-aprendizagem; 2) a faculdade atribuída a todo ser humano e que se constitui na prerrogativa de aprender, de ensinar e de se aperfeiçoar; e 3) o ramo da ciência jurídica especializado na área educacional."

\footnotetext{
${ }^{6}$ Para o autor, "Constituição cultural" corresponde ao "conjunto de princípios e regras constitucionais respeitantes aos direitos e deveres culturais e às correspondentes incumbências e instituições do Estado e da sociedade" (cf. Jorge Miranda, Manual de Direito Constitucional, Tomo IV, 3. ed., Coimbra: Coimbra Editora, 2000, p. 429).

${ }^{7}$ Jorge Miranda, Manual de Direito Constitucional, p. 429.

${ }^{8}$ Elias de Oliveira Motta, Direito Educacional e educação no século XXI, p. 51.
} 
A distinção entre direito público e direito privado remonta ao Direito Romano. ${ }^{9}$ Hans Kelsen aponta que não há uma definição dos conceitos de direito público e direito privado que não seja ambígua, e que a base tradicional dessa distinção é a sistematização do Direito. ${ }^{10}$ No mesmo sentido, para Tércio Sampaio Ferraz Júnior "a distinção entre a esfera pública e a privada, confusa e sem nitidez, faz da separação entre direito público e privado uma tarefa difícil de realizar". ${ }^{11}$ No entanto, até os dias de hoje, a distinção entre direito público e direito privado é utilizada para fins didáticos, para sistematização do Direito. Nesse sentido, tradicionalmente se estabelece como elemento diferenciador o titular do direito: direito público regula as relações em que o Estado é parte, e direito privado disciplina as relações entre particulares. ${ }^{12}$

Com base nessa dicotômica, o Direito Educacional situa-se no âmbito do direito público, uma vez que trata de assunto que constitui um dever do Estado constitucionalmente estabelecido, embora seja parcialmente submetido ao regime privado, quando a atividade educacional é desenvolvida pelo particular. Dentro das grandes áreas do direito, relaciona-se, de forma principal, com o Direito Constitucional, tendo em vista sua disciplina constitucional detalhada, tanto no que diz respeito ao direito à educação, quanto no que se refere ao dever do Poder Público de organizar os sistemas educacionais, na consolidação do que neste trabalho se denomina direito da educação. Daí a sua relação direta com o Direito Administrativo, por conta da necessidade da organização administrativa do Estado, em todos os níveis federativos, para o desenvolvimento de atividades educacionais.

Mesmo antes da promulgação da Constituição de 1988, que conferiu tratamento constitucional mais detalhado e sistemático à educação brasileira, Esther de Figueiredo Ferraz já apontava a necessidade do Direito Educacional merecer um tratamento jurídico específico:

"De maneira que existe o direito educacional no sentido objetivo, ou seja, no sentido de um conjunto, de um riquíssimo conjunto de normas e princípios jurídicos regulamentadores da

\footnotetext{
${ }^{9}$ A esse respeito, é famoso o trecho de Ulpiano (Digesto, 1.1.1.2): "Publicum jus est quod ad statum rei romanae sppectat, privatum, quod ad singulorum utilitatem" ("O direito público diz respeito ao estado da coisa romana, à polis ou civitas, o privado à utilidade dos particulares”) (cf. Tércio Sampaio Ferraz Júnior, Introdução ao estudo do direito: técnica, decisão, dominação, 2. ed., São Paulo: Atlas, 1994, p. 134).

${ }^{10}$ Cf. Hans Kelsen, Teoria geral do Direito e do Estado, (tradução de Luís Carlos Borges), São Paulo: Martins Fontes, 2005, p. 289.

${ }^{11}$ Tércio Sampaio Ferraz Júnior, Introdução ao estudo do direito, p. 138.

${ }^{12}$ Cf. Maria Helena Diniz, Compêndio de introdução à ciência do direito, 18 ed., São Paulo: Saraiva, 2006, p. 254 .
} 
atividade educacional, desenvolvidas pelo Estado e pelas pessoas e entidades particulares, por eles autorizadas e fiscalizadas.

Tais normas e princípios possuem uma suficiente especificidade para merecer um tratamento científico por parte de dogmática jurídica, sendo considerados uma categoria e um capítulo do direito administrativo, quando não numa linha mais ambiciosa, um ramo dessa disciplina, ou até mesmo, uma disciplina autônoma, exatamente porque a matéria tratada por essas leis - a educação - é de uma tal especificidade, de uma tal dignidade, diz tão de perto o respeito ao maior interesse da criatura humana, que é a educação, que deveria ser regulada em capítulo à parte, para bem, até mesmo, do Poder Judiciário, na hora de aplicar a lei." ${ }^{\text {13 }}$

Renato Alberto Teodoro Di Dio, em tese de livre docência apresentada na Faculdade de Educação da Universidade de São Paulo, há mais de trinta anos já apontava a existência do Direito Educacional como ramo jurídico autônomo:

"Direito Educacional é o conjunto de normas, princípios, leis e regulamentos, que versam sobre as relações de alunos, professores, administradores, especialistas e técnicos, enquanto envolvidos, mediata ou imediatamente, no processo ensino-aprendizagem..". ${ }^{14}$

Na mesma linha, Paulo Nader também defende a autonomia do Direito Educacional, indicando a estreita ligação entre Educação e Direito:

"É através da educação que se pode dotar o corpo social de um status intelectual, capaz de promover a superação de seus principais problemas. Para assegurar o conhecimento, a cultura, a pesquisa, o Estado utiliza-se de numerosas leis que organizam a educação em todos os seus níveis. [...] Tal a presença da educação no Direito Positivo, que já se fala na existência de um Direito Educacional. $" 15$

Edivaldo Boaventura indica que o Direito Educacional já dispõe de amplo volume de doutrinas, princípios e normas, bem como de método próprio para conhecimento de seu objeto, ${ }^{16}$ mas reconhece, no entanto - em análise realizada no ano de promulgação da Lei de Diretrizes e Bases da Educação atualmente em vigência - que se tratava de matéria tratada por legislação ainda assistemática e dispersa. ${ }^{17}$

${ }^{13}$ Esther de Figueiredo Ferraz, Alternativas da educação, Rio de Janeiro: José Olympio, 1969, p. 53 apud Edivaldo M. Boaventura, "Um ensaio de sistematização do direito educacional", Revista de Informação Legislativa 131 (1996), p. 39.

${ }^{14}$ Renato Alberto Teodoro Di Dio, Contribuição à sistematização do direito educacional, p. 25 apud Nelson Joaquim, Direito educacional brasileiro: história, teoria e prática, Rio de Janeiro: Livre Expressão, 2009, p. 113.

${ }^{15}$ Paulo Nader, Introdução ao estudo do direito, 24. ed., Rio de Janeiro: Forense, 2004, p. 55.

${ }^{16}$ Cf. Edivaldo M. Boaventura, "Um ensaio de sistematização do direito educacional", p. 42.

${ }^{17}$ Cf. Edivaldo M. Boaventura, "Um ensaio de sistematização do direito educacional", p. 45. 
Segundo Regina Garcia de Paiva, a sistematização das normas jurídicas educacionais está em estágio avançado, mas ainda constitui o que ela denomina como Direito Educacional "de fato", necessitando da consolidação do Direito Educacional "de direito", como ramo especializado da ciência jurídica. ${ }^{18} \mathrm{Na}$ realidade, o Direito Educacional está em fase de consolidação, por meio da edição sistemática de normas jurídicas, ${ }^{19}$ bem como por meio do estudo sistemático de seus diversos aspectos por parte da doutrina. ${ }^{20}$

De fato, o Direito Educacional possui suas normas jurídicas fundamentais: a Constituição apresenta seus objetivos, princípios e normas organizacionais fundamentais; a Lei de Diretrizes e Bases da Educação fornece, no plano legal, a sua disciplina jurídica fundamental, com maior grau de detalhamento e integração. No plano doutrinário, há uma longa tradição de homogeneização de entendimentos jurídicos peculiares à educação por meio de decisões proferidas pelo Conselho Federal de Educação e, posteriormente, Conselho Nacional de Educação, ${ }^{21}$ bem como pelos conselhos estaduais de educação.

O presente trabalho tem por objetivo colaborar para a consolidação desse ramo jurídico, por meio da análise e sistematização de um de seus aspectos relevantes: a atividade regulatória da educação superior.

Por essa razão, trabalha-se com o seguinte conceito de Direito Educacional: um conjunto de normas jurídicas de direito público que disciplinam o direito à educação, bem como as relações jurídicas e a organização das atividades administrativas destinadas a sua efetivação, nos diversos níveis, por parte do Estado, por meio da prestação direta ou por meio da regulação da qualidade de sua prestação pela iniciativa privada.

\subsection{Direito à educação}

Esse subcapítulo buscará compreender o direito à educação em seus diversos aspectos. Por essa razão, a fim de compreender o conteúdo do direito à educação, é

\footnotetext{
${ }^{18}$ Cf. Regina Garcia de Paiva, "Direito educacional: do fato para o Direito", in André Trindade (coord.), Direito educacional em uma ótica sistêmica, Curitiba: Juruá, 2010, p. 95.

${ }_{19}$ Pode-se mencionar, como exemplo, a consolidação do marco regulatório da educação superior, objeto específico do presente trabalho.

${ }^{20}$ Nesse aspecto, merece destaque o lançamento da Revista de Direito Educacional, de periodicidade semestral, editada pela Editora Revista dos Tribunais.

${ }^{21}$ A Revista Documenta é a publicação oficial das decisões do antigo Conselho Federal de Educação (CFE) e do atual Conselho Nacional de Educação (CNE).
} 
necessário conceituar a educação, que, para Dalmo de Abreu Dallari "é um processo de aprendizagem e aperfeiçoamento, por meio do qual as pessoas se preparam para a vida". ${ }^{22}$ Maria Garcia entende que a educação "abrange o conjunto de processos pelos quais a pessoa descobre e desenvolve capacidades, vocação e atitudes, como formas de conduta de valor positivo para si mesma e para a sociedade em que vive". ${ }^{23}$ Para a autora, a educação "vem a significar o processo do desenvolvimento da capacidade física, intelectual e moral da criança e do ser humano em geral, visando à sua melhor integração individual e social". ${ }^{24}$ De fato, a educação tem como elemento fundamental a relação entre a maximização das potencialidades humanas e sua projeção ao mundo exterior. Essa noção está presente na etimologia da palavra educação, que deriva da expressão em latim educare - ligada a educere, verbo composto pelo prefixo ex (fora) e por ducere (conduzir levar) - que significa literalmente "conduzir para fora", ou seja, preparar o indivíduo para o mundo. ${ }^{25} \mathrm{Na}$ mesma linha, Mônica Sifuentes aponta os dois objetivos a serem alcançados pela educação fundamental:

“1. Educação para si - correspondente à meta de cada indivíduo no seu aperfeiçoamento pessoal, pelo desenvolvimento da capacidade própria de aprendizagem, a compreensão do ambiente natural, social e político em que vive, da tecnologia, artes e valores em que se fundamenta a sociedade; 2. Educação para o outro - com vistas à educação como prática social, como instrumento de aprimoramento da vida em sociedade. Nessa ótica, o legislador coloca como objetivos a serem alcançados o desenvolvimento da capacidade de aprender com vista à formação de atitudes e valores, além do fortalecimento dos laços familiares, da solidariedade e da tolerância recíproca em que se assenta a convivência social."26

Esse duplo aspecto - educação para si e para o outro - fundamental para o estabelecimento de uma convivência harmônica em sociedade, também é ressaltado por Elias de Oliveira Motta em sua definição de educação:

“A Educação constitui-se, portanto, no processo pelo qual o ser humano, por um lado, adquire conhecimentos e desenvolve sua capacidade intelectual, sua sensibilidade afetiva e suas habilidades psicomotoras. Por outro lado, é também o processo pelo qual ele transmite tudo isso para outra pessoa. A Educação engloba, pois, de forma indissociável, tanto os processos de

22 Dalmo de Abreu Dallari, Direitos humanos e cidadania, São Paulo: Editora Moderna, 1998, p. 47.

${ }^{23}$ Maria Garcia, "Educação, Cultura e Desporto, (arts. 205 a 217)", in Sônia Yuriko Kanashiro Tanaka (org.), Direito Constitucional. São Paulo: Malheiros, 2009, p. 180.

${ }^{24}$ Maria Garcia, "Educação, Cultura e Desporto, (arts. 205 a 217)”, p. 181.

25 Cf. André Trindade / Edval Luiz Mazzari Júnior, "Autonomia universitária e direito educacional", in André Trindade (coord.), Direito universitário e educação contemporânea, Porto Alegre: Livraria do Advogado, 2009, p. 11.

${ }^{26}$ Mônica Sifuentes, Direito fundamental à educação, 2. ed., Porto Alegre: Núria Fabris Editora, 2009, p. 42. 
aprendizagem quanto os de ensino, e envolve, normalmente, dois interlocutores, o educando e o educador, ou o educando e algum meio educativo. ${ }^{27}$

Por se apresentar de tal maneira fundamental para a vida em sociedade, José Afonso da Silva afirma que "a educação, como processo de reconstrução da experiência, é um atributo da pessoa humana, e, por isso, tem que ser comum a todos". ${ }^{28}$

A Lei $\mathrm{n}^{\circ}$ 9.394, de 20 de dezembro de 1996 (Lei de Diretrizes e Bases da Educação Nacional - LDB) apresenta o conceito legal de educação: "a educação abrange os processos formativos que se desenvolvem na vida familiar, na convivência humana, no trabalho, nas instituições de ensino e pesquisa, nos movimentos sociais e organizações da sociedade civil e nas manifestações culturais". ${ }^{29}$ A LDB esclarece que seu objeto é disciplinar apenas um aspecto da educação: a educação escolar - aquela que se desenvolve por meio do ensino em instituições próprias, ${ }^{30}$ tendo em vista que a educação constitui também dever da família e desenvolvimento em colaboração com a sociedade. ${ }^{31}$

Por conta do papel fundamental que cumpre, a educação constitui objeto de análise no presente trabalho, a fim de compreender seu tratamento normativo dado pelo ordenamento jurídico brasileiro, por meio de normas constitucionais, tratados internacionais, leis e normas infralegais. Essa análise terá caráter mais genérico no presente capítulo, sendo aprofundado nos capítulos seguintes no que se refere à educação superior.

\subsubsection{Objetivos da educação}

A Constituição brasileira de 1988 estabelece os objetivos fundamentais da educação: o pleno desenvolvimento da pessoa, seu preparo para o exercício da cidadania e sua qualificação para o trabalho. ${ }^{32}$ Dalmo de Abreu Dallari aponta que uma característica fundamental do ser humano, a diferenciá-lo das outras espécies animais, é a possibilidade de promover seu próprio desenvolvimento, o que, para Pico Della Mirandola, no século XV, caracterizaria a essência da dignidade humana. ${ }^{33}$ Dessa maneira, o que

${ }^{27}$ Elias de Oliveira Motta, Direito Educacional e educação no século XXI: com comentários à nova Lei de Diretrizes e Bases da Educação Nacional. Brasilia: UNESCO, 1997, p. 75.

${ }^{28}$ José Afonso da Silva, Comentário contextual à Constituição, 7. ed., São Paulo: Malheiros, 2010, p. 800.

${ }^{29} \mathrm{LDB}$, artigo $1^{\circ}$, caput.

${ }^{30} \mathrm{LDB}$, artigo $1^{\mathrm{o}}, \S 1^{\mathrm{o}}$.

${ }^{31}$ Constituição da República Federativa do Brasil, artigo 205.

${ }^{32}$ Constituição da República Federativa do Brasil, art. 205.

${ }^{33}$ Cf. Dalmo de Abreu Dallari, "Educação e Preparação para a Cidadania", p 324. 
caracteriza o ser humano é o seu potencial enorme para ser desenvolvido. ${ }^{34}$ A educação, entendida como processo, é o mecanismo que deve proporcionar os meios para que a pessoa possa desenvolver todas as suas potencialidades, envolvendo aspectos materiais e imateriais das necessidades próprias de cada um, a fim de efetivar os direitos da igualdade e da liberdade. ${ }^{35}$ A educação se apresenta, dessa maneira, como metadireito fundamental, pois se apresenta como condição necessária para a efetivação dos demais diretos fundamentais.

No que se refere à educação como preparação para o exercício da cidadania, ao comentar os dispositivos da Constituição de 1946, Sampaio Dória estabeleceu a relação direta entre a educação e democracia:

"Nas autocracias, quanto mais afundar-se o povo na ignorância, melhor. Quando muito, monopolizar o governo a educação, para fanatizar a massas, e silenciá-las no trabalho.

Nas democracias, quanto mais educado o povo na escola da liberdade, melhor. Quando muito, intervenha o Estado, para suprir as deficiências individuais em educação.

Tendo proclamado, no art. $1^{\circ}$ da Constituição, para si, o regime democrático, o que cumpre em consequiência ao país é tudo fazer para que o povo se eduque na escola da liberdade, na consciência do seu destino, na capacidade para o trabalho.

Sem educação popular intensa e extensa, o voto com que se constitua o poder, será antes flagelo que providência. A educação é o problema básico da democracia." ${ }^{„ 36}$

Para Theodor W. Adorno, a educação é fundamental para a produção de uma consciência verdadeira, pressuposto para a emancipação, entendida como decisão consciente e independente de cada pessoa em particular, ${ }^{37}$ condição básica para o funcionamento da democracia:

"Isto seria inclusive da maior importância política; sua idéia, se é permitido dizer assim, é uma exigência política. Isto é: uma democracia com o dever de não apenas funcionar, mas operar conforme seu conceito, demanda pessoas emancipadas. Uma democracia efetiva só pode ser imaginada enquanto uma sociedade de quem é emancipado. ${ }^{38}$

${ }^{34}$ Cf. Dalmo de Abreu Dallari, "Educação e Preparação para a Cidadania", p. 324.

${ }^{35}$ Cf. Maria Garcia, "Educação, Cultura e Desporto, (arts. 205 a 217)", p. 179.

${ }^{36}$ Antônio de Sampaio Dória, Direito constitucional: comentários à Constituição de 1946 (arts. 141, § 11 a 218). Vol. 4. São Paulo, Max Limonad, 1960, pp. 765-766.

${ }^{37}$ Cf. Theodor W. Adorno, Educação e emancipação. (tradução de Wolfgang Leo Maar). Rio de Janeiro: Paz e Terra, 2010, p. 142.

${ }^{38}$ Theodor W. Adorno, Educação e emancipação, pp. 141-142. 
Nesse sentido, a educação, como direito social - além de possui uma estreita relação com os demais direitos fundamentais, tanto no que se refere aos chamados de primeira ou aos de segunda geração ${ }^{39}$ - vincula-se diretamente, como visto, com o próprio funcionamento da democracia e do Estado, conforme aponta Dalmo de Abreu Dallari:

"Um dos objetivos fundamentais da educação, que deve ser proporcionada a todos os seres humanos, em benefício do indivíduo mas também de toda a humanidade, é o preparo para a convivência ativa, o que pode ser traduzido, em termos modernos, como preparação para o exercício da cidadania." 40

Mas o autor alerta para o fato de que a preparação para a cidadania não se resume a informações a respeito do funcionamento do sistema eleitoral e do exercício do direito ao voto:

"mas também informar e despertar a consciência sobre o valor da pessoa humana, suas características essenciais, sua necessidade de convivência e a obrigação de respeitar a dignidade de todos os seres humanos, independentemente de sua condição social ou de atributos pessoais." 41

Fábio Konder Comparato também aponta a ligação direta entre educação e política: "Falar sobre educação e política faz sentido dentro de uma perspectiva histórica: são problemas que se realizam, que se põem, que se resolvem ou não se resolvem, numa sequiência de fatos e situações históricos." ${ }^{42}$

A qualificação da pessoa para o trabalho também constitui um dos objetivos fundamentais da atividade educacional, uma vez que tem relação direta com o desenvolvimento da pessoa e o exercício de todos os seus direitos fundamentais - dentre os quais, de forma direta, o direito ao trabalho. Além disso, existe a inegável externalidade positiva da educação, ${ }^{43}$ pois a somatória das qualificações individuais contribui significativamente para o desenvolvimento econômico e social do país, acarretando benefícios para a sociedade como um todo. Esse aspecto foi tratado pela Lei de Diretrizes e

\footnotetext{
${ }^{39}$ Cf. 1.2.2.

${ }^{40}$ Dalmo de Abreu Dallari, "Educação e Preparação para a Cidadania", p. 325.

${ }^{41}$ Dalmo de Abreu Dallari, "Educação e Preparação para a Cidadania", p. 345.

${ }^{42}$ Fábio Konder Comparato, Educação, Estado e Poder, São Paulo: Brasiliense, 1987, p. 94.

${ }^{43}$ Há externalidade sempre que uma relação jurídica produz efeitos - geralmente não-mensuráveis - para sujeitos que dela não participam, podendo ser positivas ou negativas (cf. Calixto Salomão Filho, Regulação da atividade econômica, p. 198). Um exemplo de externalidade positiva é a vacinação, pois quando um indivíduo é vacinado, além de ser beneficiado, colabora com a coletividade, uma vez que não será mais transmissor da respectiva doença. Um exemplo de externalidade negativa é a poluição industrial, que não atinge necessariamente os consumidores diretos, mas sim os moradores das áreas próximas (cf. Calixto Salomão Filho, Regulação da atividade econômica, p. 198).
} 
Bases da Educação Nacional, que estabeleceu que a educação escolar deve vincular-se ao mundo do trabalho e à prática social. ${ }^{44}$

\subsubsection{Educação como direito fundamental social}

Tendo em vista o fato de que a educação é elevada à condição de direito fundamental social, faz-se necessário estudo a respeito do conceito de direitos sociais, que foram tratados pela Constituição brasileira com forte influência do constitucionalismo luso-espanhol, que, apegado à doutrina alemã, confere forte ênfase aos direitos fundamentais. ${ }^{45}$ A esse respeito, é importante frisar que o tratamento dado à educação pela Constituição de 1988 está inserido no título relativo à Ordem Social, tendo em vista a sua relação direta com outros direitos sociais. No que se refere ao estudo da Ordem Econômica, dado o seu reflexo na atividade regulatória do Estado, será abordado no presente trabalho estudo a respeito da natureza jurídica da atividade educacional. ${ }^{46}$

O desafio do Estado brasileiro, de efetivar o Estado Social instituído constitucionalmente pela Constituição de 1988, a fim de atingir determinados objetivos de natureza social, é bem explicado por Gilberto Bercovici:

“O Estado Brasileiro constituído após a Revolução de 1930 é, portanto, um Estado estruturalmente heterogêneo e contraditório. É um Estado Social sem nunca ter conseguido instaurar uma sociedade de bem-estar: moderno e avançado em determinados setores da economia, mas tradicional e repressor em grande parte das questões sociais."47

O constitucionalismo que adveio após a Segunda Guerra, inaugurado pela Lei Fundamental da Alemanha, inovou no que diz respeito a direitos sociais, uma vez que não apenas os estruturou em regras e princípios, de forma generosa, mas também alterou o seu paradigma ao instituir os tribunais constitucionais - sendo pioneiro, mais uma vez, o

\footnotetext{
${ }^{44} \mathrm{LDB}$, artigo $1^{\mathrm{o}}, \S 2^{\mathrm{o}}$.

${ }^{45}$ Cf. Marcus Aurélio de Freitas Barros, Controle jurisdicional de políticas públicas: parâmetros objetivos e tutela coletiva, Porto Alegre: Sérgio Antonio Fabris, 2008, p. 21, e Mônica Sifuentes, Direito fundamental à educação, p. 19. A esse respeito, vide Lurdes Keiko Oyama, "O Direito à Educação na Constituição Portuguesa", Revista de Direito Educacional 1 (2010), 171-205.

${ }^{46}$ Nesse aspecto, é importante frisar que a atividade educacional não se insere no regime jurídico das atividades econômicas em sentido estrito, fundamentadas no artigo 173 da Constituição, nem no regime jurídico dos serviços públicos, previsto no artigo 175 da Constituição, por ser livre à iniciativa privada, independentemente de licitação. Dado esse aspecto peculiar, a natureza jurídica da atividade educacional merece estudo específico (cf. 3.1).

47 Gilberto Bercovici, "Desenvolvimento, Estado e Administração Pública", in José Eduardo Martins Cardozo / João Eduardo Lopes Queiroz / Márcia Walquíria Batista dos Santos (orgs.), Curso de Direito Administrativo Econômico. Vol II. São Paulo: Malheiros, 2006, p. 33.
} 
Tribunal Constitucional da Alemanha de $1950 .{ }^{48}$ Os tribunais constitucionais constituem um importante mecanismo institucional para a efetivação dos direitos fundamentais sociais.

Gilberto Bercovici aponta que a relação entre a dignidade da pessoa humana e a constituição econômica tem origem na Constituição de Weimar - assim como quase tudo que diz respeito ao constitucionalismo contemporâneo. $\mathrm{Na}$ segunda parte dessa Constituição ("Dos direitos fundamentais dos alemães”), foi incluído pela primeira vez na história constitucional europeia, um capítulo dedicado à ordem econômica ("Da vida econômica"), cujo dispositivo inaugural - artigo 151, caput - prescrevia que a vida econômica era fundada nos limites da justiça e da existência digna. A Constituição de Weimar influenciou as demais constituições brasileiras democráticas: de 1934 (artigo 115, caput), 1946 (artigo 145) e 1988 (170, caput). A partir da vinculação entre constituição econômica e dignidade humana, vários autores desenvolveram a ideia de mínimo existencial. ${ }^{49}$ No entanto, segundo o autor:

"Alguns dos mais influentes autores que defendem o mínimo existencial partem de uma concepção liberal e individualista de garantia mínima pelo Estado de condições de existência humana para o exercício das liberdades., 50

Por essa razão, a discussão a respeito do mínimo existencial mais adequada à Constituição de 1988 é a que tem por base os direitos sociais - tendo em vista o caráter social dessa constituição, vinculando a dignidade humana à realização da democracia econômica e social. ${ }^{51}$

Uma vez caracterizado o direito à educação como direito social, ilustrativa é a contribuição de José Afonso da Silva, para quem direitos sociais constituem uma dimensão dos direitos fundamentais do homem, que se relaciona com o princípio da igualdade, tomado em sua dimensão material:

“direitos sociais, como dimensão dos direitos fundamentais do homem, são prestações positivas proporcionadas pelo Estado direta ou indiretamente, enunciadas em normas

\footnotetext{
${ }^{48}$ Cf. Maria Paula Dallari Bucci, "O conceito de política pública em direito”, p. 5-6.

${ }^{49}$ Cf. Gilberto Bercovici, "Constituição econômica e dignidade da pessoa humana", Revista da Faculdade de Direito da Universidade de São Paulo 102 (2007), pp. 457-460.

${ }^{50}$ Gilberto Bercovici, "Constituição econômica e dignidade da pessoa humana", p. 460.

${ }^{51}$ Cf. Gilberto Bercovici, "Constituição econômica e dignidade da pessoa humana”, pp. 461-462.
} 
constitucionais, que possibilitam melhores condições de vida aos mais fracos, direitos que tendem a realizar a igualização de situações sociais desiguais." ${ }^{.52}$

Para Robert Alexy, os direitos fundamentais sociais (sozialen Grundrechte) são direitos à prestação em sentido estrito (Leistungsrechte im engeren Sinne), assim definidos:

"Direitos a prestação em sentido estrito são direitos do indivíduo perante o Estado a algo que o indivíduo, se dispusesse de meios financeiros suficientes e se houvesse uma oferta suficiente pelo mercado, poderia também obter de privados. Quando se fala em direitos fundamentais sociais, como direitos a assistência à saúde, ao trabalho, à moradia e à educação, se esta referindo, em primeiro lugar, a direitos a prestação em sentido estrito."53

Os direitos fundamentais sociais são, por essa razão, direitos-meio, cuja principal função é assegurar que toda pessoa tenha condições de gozar os direitos individuais de primeira geração. ${ }^{54}$

A distinção dos direitos fundamentais em gerações se deve, em grande medida, pelo fato dos direitos fundamentais de segunda geração se distinguirem dos de primeira geração - direitos civis e políticos - por exigirem uma ação efetiva do Estado para sua implementação, mas também devido aos momentos diferentes em que foram tratados na história do constitucionalismo. Isto porque as constituições passaram a tratar sistematicamente de questões relativas à intervenção do Estado na ordem econômica e social a partir da Constituição mexicana de 1917. No Brasil, a Constituição de 1934 foi a que primeiro trouxe disposições relativas a essa matéria, influenciada, em grande medida, pela Constituição alemã de Weimar, de $1919 .{ }^{55}$ A partir desse momento histórico, os direitos sociais passaram a ser tratados pela ordem constitucional.

Segundo Paulo Bonavides, os direitos de segunda geração - que nasceram "abraçados ao princípio da igualdade" 56 - passaram, inicialmente, por um ciclo de baixa normatividade ou tiveram eficácia duvidosa, não chegando, nos dias de hoje, a ser tão justiciáveis quanto os da primeira geração, embora com a tendência de a tornarem-se. ${ }^{57}$ Para Fábio Konder Comparato, o reconhecimento dos direitos econômicos e sociais "foi o

\footnotetext{
${ }^{52}$ José Afonso da Silva, Curso de direito constitucional positivo. 32. ed. São Paulo: Malheiros, 2010, p. 286.

${ }^{53}$ Robert Alexy, Theorie der Grundrechte, p. 454.

${ }^{54}$ Cf. Maria Paula Dallari Bucci, "O conceito de política pública em direito", in Maria Paula Dallari (org.), Políticas públicas: reflexões sobre o conceito jurídico, São Paulo: Saraiva, 2006, p. 3.

${ }^{55}$ Cf. José Afonso da Silva, Curso de direito constitucional positivo, p. 285.

${ }^{56}$ Paulo Bonavides, Curso de direito constitucional. 26. ed. São Paulo: Malheiros, 2011, p. 564.

${ }^{57}$ Cf. Paulo Bonavides, Curso de direito constitucional, pp. 564-565.
} 
principal benefício que a humanidade recolheu do movimento socialista, iniciado na primeira metade do século XIX”. 58

No que se refere à estrutura normativa, os direitos sociais se caracterizam por exigirem, em sua maioria, prestações positivas do Estado impostas pela Constituição, ${ }^{59}$ estando inseridos no espaço essencial do cidadão, independentemente da possibilidade de sua imediata exequibilidade, por se tratarem de direitos originários, ou seja, fundados diretamente na Constituição. ${ }^{60}$

José Joaquim Gomes Canotilho aponta que, do ponto de vista jurídicoconstitucional, existem quatro possíveis conformações jurídicas dos direitos sociais, econômicos e culturais: como normas programáticas, como normas de organização, como garantias institucionais e como direitos públicos subjetivos. ${ }^{61}$ Nas normas programáticas, condensam-se os princípios definidores dos fins do Estado, de cunho eminentemente social. As normas de organização destinadas à realização de certos direitos sociais. ${ }^{62}$ As garantias institucionais traduzem-se numa imposição dirigida ao legislador, obrigando-o a respeitar a essência das instituições e, ao mesmo tempo, protegê-la. Embora considere todas essas dimensões, o autor entende que "os direitos sociais são compreendidos como autênticos direitos subjectivos inerentes ao espaço existencial do cidadão, independentemente da sua justiciabilidade e exeqüibilidade imediatas." ${ }^{\circ 3} \mathrm{O}$ direito à educação apresenta-se nas quatro dimensões apontadas pelo autor.

Por essa razão, o direito à educação é um direito social completo (“Grundrecht als Ganzes") - um feixe de posições de direitos fundamentais ("ein Bündel von grundrechtlichen Positionen") de diferentes conteúdos e estruturas, segundo a doutrina de Robert Alexy. ${ }^{64}$

O sistema constitucional brasileiro, ao buscar efetivar um conceito de educação integral, deu a ela o tratamento de direito social, relacionando-a com os demais direitos

\footnotetext{
${ }^{58}$ Cf. Fábio Konder Comparato, A afirmação histórica dos direitos humanos, p. 53.

${ }^{59}$ Cf. José Afonso da Silva, Aplicabilidade das normas constitucionais, 6. ed., São Paulo: Malheiros, 2003, p. 151.

${ }^{60}$ Cf. José Joaquim Gomes Canotilho, Constituição dirigente e vinculação do legislador: contributo para a compreensão das normas constitucionais programáticas, 2. ed., Coimbra: Coimbra Editora, 2001, p. 371.

${ }^{61}$ Cf. José Joaquim Gomes Canotilho, Direito constitucional e teoria da Constituição, 7. ed., Coimbra: Almedina, 2003, pp. 474-475.

${ }^{62}$ Cf. José Joaquim Gomes Canotilho, Direito constitucional e teoria da Constituição, pp. 474-475.

${ }^{63}$ José Joaquim Gomes Canotilho, Direito constitucional e teoria da Constituição, p. 476.

${ }^{64}$ Robert Alexy, Theorie der Grundrechte, pp. 224-229.
} 
fundamentais. A educação, assim, situa-se, ao mesmo tempo como um direito-fim, a ser efetivado por seu valor intrínseco, e como um direito-meio, como instrumento para a efetivação dos demais direitos fundamentais. ${ }^{65}$

No que se refere à educação em si, trata-se de direito humano essencial, e é por essa razão que o direito à educação é estabelecido expressamente pela Constituição, como:

"reconhecimento de que, sem a possibilidade de desenvolvimento intelectual, da obtenção e ampliação de conhecimentos, do estímulo ao desenvolvimento psíquico, e sem receber ensinamentos sobre a convivência e as formas de integração social, a pessoa não chegará a ser livre e não será tratada como igual" ${ }^{66}$

A Declaração da Conferência Regional de Educação Superior na América Latina e no Caribe, de 2008, preparatória da Conferência Mundial sobre o Ensino Superior, realizada pela UNESCO, em 2009, afirmou a educação superior como direito humano e bem público social, acarretando deveres para os Estados, as sociedades e as comunidades acadêmicas:

“A Educação Superior é um direito humano e um bem público social. Os Estados têm o dever fundamental de garantir este direito. Os Estados, as sociedades nacionais e as comunidades acadêmicas devem ser os atores que definem os princípios básicos nos quais se fundamenta a formação dos cidadãos e cidadãs, cuidando para que ela seja pertinente e de qualidade.,67

Dessa maneira, o direito à educação deve ser considerado como direito fundamental social, à luz da ideologia contida na Constituição de 1988, de caráter social. A educação tratada com base em uma ideologia liberal incorre no grave risco de se tornar mais uma mercadoria no setor de serviços, perdendo seu caráter social de promotora da efetivação dos demais direitos. ${ }^{68}$ Competem ao Estado e à sociedade a implementação de políticas públicas que efetivem, de forma progressiva, o direito à educação, em todos os níveis, não apenas de forma quantitativa, pela ampliação de acesso, mas também por meio

65 A esse respeito, muito pertinente é a seguinte obra, que apresenta diversos artigos que relacionam a educação com outros direitos humanos específicos: Cf. Richard Pierre Claude / George Andreopoulos (orgs.), (tradução de Ana Luiza Pinheiro), Educação em direitos humanos para o século XXI, São Paulo: EDUSP, 2007.

${ }^{66}$ Dalmo de Abreu Dallari, "Educação e Preparação para a Cidadania", p. 343.

${ }^{67}$ Declaração da Conferência Regional de Educação Superior na América Latina e no Caribe. Avaliação 14 (2009), p. 237.

${ }^{68}$ Cf. Eliane Ferreira de Sousa, Direito à educação: requisito para o desenvolvimento do país, São Paulo: Saraiva, 2010, p. 69. 
da garantia de contínua melhoria dos padrões de qualidade, consagrado como princípio setorial da educação. ${ }^{69}$

\subsubsection{Educação e políticas públicas}

Os direitos sociais exigem prestações positivas por parte do Estado, que só podem ser implementadas por meio de ações coordenadas que visem a atingir objetivos constitucionalmente predeterminados. Dessa maneira, um importante papel é desempenhado pelas políticas públicas, assunto que apenas recentemente vem sendo estudado pelo universo jurídico brasileiro. As políticas públicas têm importância nuclear para efetivação dos direitos fundamentais sociais, que exigem concretização pela via coletiva, ultrapassando o espectro da tutela individual. ${ }^{70}$

Nesses termos, passa-se a buscar a conceituação de políticas públicas. Ronald Dworkin, partindo da crítica ao positivismo jurídico de Herbert Hart, classifica as normas jurídicas como regras, políticas ("policies") ou princípios, ${ }^{71}$ apresentando o seguinte conceito de policy: ${ }^{72}$

\footnotetext{
"Denomino "política" aquele tipo de padrão que estabelece um objetivo a ser alcançado, em geral uma melhoria em algum aspecto econômico, político ou social da comunidade (ainda que certos objetivos sejam negativos pelo fato de estipularem que algum estado atual deve ser protegido contra mudanças adversas)." ${ }^{, 73}$
}

Dworkin aponta como fundamento das políticas públicas o objetivo a ser alcançado, da mesma maneira que Fabio Konder Comparato, em um dos primeiros trabalhos no Brasil, que tratou do assunto com enfoque jurídico. Para ele, as políticas públicas, do ponto de vista jurídico, se apresentam como um conjunto organizado de normas e atos tendentes à realização de um objetivo determinado. ${ }^{74}$

\footnotetext{
${ }^{69}$ Constituição da República Federativa do Brasil, artigo 206, VII.

${ }^{70}$ Cf. Marcus Aurélio de Freitas Barros, Controle jurisdicional de políticas públicas, p. 22.

${ }^{71}$ Cf. Ronald Dworkin, Levando os direitos a sério. (tradução de Jefferson Luiz Camargo). 2 ed. São Paulo: Martins Fontes, 2007, pp. 35-36.

${ }^{72} \mathrm{O}$ termo policy, tradicionalmente, é traduzido para o português como programas governamentais, enquanto o termo politics, significa atividade política em sentido amplo (cf. Maria Paula Dallari Bucci, "O conceito de política pública em direito", p. 11).

${ }^{73}$ Ronald Dworkin, Levando os direitos a sério, p. 36.

${ }^{74}$ Cf. Fábio Konder Comparato, "Ensaio sobre o juízo de constitucionalidade de políticas públicas", Revista de Informação Legislativa 138 (1998), 39-48, p. 45.
} 
Maria Paula Dallari Bucci, uma das pioneiras no estudo jurídico das políticas públicas no Brasil, aponta que para se atingir tais objetivos, é necessária uma ação governamental coordenada:

"Políticas públicas são programas de ação governamental visando a coordenar os meios à disposição do Estado e as atividades privadas, para a realização de objetivos socialmente relevantes e politicamente determinados. Políticas públicas são "metas coletivamente conscientes" e, como tais, um problema de direito público, em sentido lato."75

As políticas públicas constituem assunto relativamente recente estudado pelo Direito, se tratando de temática oriunda da Ciência Política e da Ciência da Administração Pública. Dessa maneira, para definir as políticas públicas como objeto de estudo jurídico, exige-se a abertura do Direito para a interdisciplinaridade. No campo jurídico, vem sendo tratada pela Teoria do Estado, pelo Direito Constitucional, pelo Direito Administrativo e pelo Direito Financeiro, principalmente. ${ }^{76}$

José Reinaldo de Lima Lopes procura estabelecer uma classificação das políticas públicas, que trazem como objetivo, em grande medida, a efetivação de direitos fundamentais sociais:

"As políticas públicas agrupam-se também em gêneros diversos: existem (1) as políticas sociais, de prestação de serviços essenciais e públicos (tais como saúde, educação, segurança e justiça, etc.), (2) as políticas sociais compensatórias (tais como a previdência e assistência social, seguro desemprego, etc.), (3) as políticas de fomento (créditos, incentivos, preços mínimos, desenvolvimento industrial, tecnológico, agrícola, etc.), (4) as reformas de base (reforma urbana, agrária, etc.), (5) políticas de estabilização monetária, e outras mais especificas ou genéricas."77

Uma questão importante para o direito é estabelecer se as políticas públicas constituem uma categoria jurídica própria. Conforme visto, Ronald Dworkin entende que as políticas públicas constituem categoria jurídica própria. Por outro lado, para Maria Paula Dallari Bucci, o critério de suporte normativo próprio pode ser falho, uma vez que a exteriorização da política pública não apresenta um padrão jurídico uniforme e claramente apreensível pelo sistema jurídico: ${ }^{78}$

\footnotetext{
${ }^{75}$ Maria Paula Dallari Bucci, Direito Administrativo e políticas públicas. São Paulo: Saraiva, 2002, p. 241.

${ }^{76}$ Maria Paula Dallari Bucci, "O conceito de política pública em direito”, p. 1.

${ }^{77}$ José Reinaldo de Lima Lopes, "Direito subjetivo e direito sociais: o dilema do Judiciário no Estado Social de Direito", in José Eduardo Faria (org.), Direitos Humanos, Direitos Sociais e Justiça, São Paulo: Malheiros, 1994, p. 133.

${ }^{78}$ Cf. Maria Paula Dallari Bucci, “O conceito de política pública em direito”, pp. 19-22.
} 
“As políticas públicas não são, portanto, categoria definida e instituída pelo direito, mas arranjos complexos, típicos da atividade político-administrativa, que a ciência do direito deve estar apta a descrever, compreender e analisar, de modo a integrar à atividade política os valores e métodos próprios do universo jurídico.,79

Na mesma linha, José Reinaldo de Lima Lopes indica, do ponto de vista jurídico, que as políticas públicas compõem um conjunto heterogêneo de medidas, ${ }^{80}$ constituindo "um complexo de decisões e normas de natureza variada". ${ }^{81}$

As políticas públicas, na medida em que se prestam a instituir uma ação coordenada e planejada para o alcance de determinados objetivos, possuem relação direta com a demanda pela implementação dos direitos fundamentais sociais - que se caracterizam por necessitar desse tipo de ação estatal para garantir sua efetivação - fruto de mudanças sociais e institucionais que culminaram na consolidação do Estado Social de Direito, conforme apontam Gilberto Bercovici e Luís Fernando Massonetto:

"Do ponto de vista da organização racional do Estado, o afloramento da contradição e as demandas por direitos das classes exploradas vai dar ensejo a uma pletora de programas, projetos e atividades, constitutivos do que se convencionou chamar políticas públicas.. ${ }^{82}$

Nesse sentido, o advento do Estado Social criou a necessidade da organização do Estado para a implementação de políticas públicas destinadas à efetivação de direitos sociais (government by policies), indo além do Estado Liberal, que tinha como característica fundamental a manutenção da segurança jurídica (government by law). ${ }^{83}$ Nesse contexto, no Estado Social "governar passou a não ser mais a gerência de fatos conjunturais, mas, também, e sobretudo, o planejamento do futuro, com o estabelecimento de políticas de médio e longo prazo". 84

O Poder Judiciário tem competência para controlar a legalidade e a constitucionalidade das políticas públicas que expressem direitos - tendo em vista que a lei não excluirá da apreciação do Poder Judiciário lesão ou ameaça a direito (artigo 5,

\footnotetext{
${ }^{79}$ Maria Paula Dallari Bucci, "O conceito de política pública em direito”, p. 31.

${ }^{80}$ Cf. José Reinaldo de Lima Lopes, “Direito subjetivo e direito sociais”, p. 134.

${ }^{81}$ José Reinaldo de Lima Lopes, "Direito subjetivo e direito sociais, p. 131.

${ }^{82}$ Gilberto Bercovici / Luís Fernando Massonetto, "Breve história da incorporação dos direitos sociais nas constituições democráticas brasileiras", Revista do Departamento de Direito do Trabalho e da Seguridade Social 3 (2007), p. 62.

${ }^{83}$ Cf. Gilberto Bercovici, Constituição econômica e desenvolvimento: uma leitura a partir da Constituição de 1988, São Paulo: Malheiros, 2005, pp. 57-58.

${ }^{84}$ Gilberto Bercovici, Constituição econômica e desenvolvimento, p. 57.
} 
XXXV, da Constituição) - excluindo-se juízos acerca de qualidade e adequação, ${ }^{85}$ submetidos à discricionariedade administrativa conferida pela legislação. A delimitação do papel do Poder Judiciário é uma das questões mais importantes do direito público contemporâneo, conforme aponta Marcus Aurélio de Freitas Barros:

"O grande desafio do estudo das políticas públicas, enfim, é delimitar as bases do contraste jurisdicional, devendo-se clarificar critérios e parâmetros que permitam a garantia dos direitos sem asfixiar a missão dos poderes políticos. ${ }^{86}$

Nesse sentido, um dos aspectos mais atuais e controversos a respeito das políticas públicas diz respeito aos limites do controle judicial a seu respeito, em especial, quando se trata de efetivação de direitos sociais. ${ }^{87} \mathrm{O}$ cerne da questão está no fato de que

${ }^{85}$ Cf. Maria Paula Dallari Bucci, “O conceito de política pública em direito”, p. 35.

${ }^{86}$ Marcus Aurélio de Freitas Barros, Controle jurisdicional de políticas públicas, p. 78.

${ }^{87}$ A esse respeito: Maria Paula Dallari Bucci. "Controle judicial de políticas públicas: possibilidades e limites", in Maria Victoria de Mesquita Benevides / Gilberto Bercovici / Claudineu de Melo (orgs.), Direitos Humanos, Democracia e República, São Paulo: Quartier Latin, 2009, 693-711; Sebastião Botto de Barros Tojal, "Controle judicial da regulamentação de políticas públicas", Revista da Academia Brasileira de Direito Constitucional 3 (2003), 185-194; Ingo Wolfgang Sarlet, "O papel da jurisdição constitucional na realização do Estado Social", Revista da Academia Brasileira de Direito Constitucional 3 (2003), 355-365; José Eduardo Faria, "O Judiciário e os direitos humanos e sociais: notas para uma avaliação da justiça brasileira", in José Eduardo Faria (org.), Direitos Humanos, Direitos Sociais e Justiça, São Paulo: Malheiros, 1994, 94-112; José Joaquim Gomes Canotilho, "O direito dos pobres no activismo judiciário", in José Joaquim Gomes Canotilho / Marcus Orione Gonçalves Correia / Érica Paula Barcha Correia (coords.), Direitos fundamentais sociais. São Paulo: Saraiva, 2010, 33-35; Flávia Piovesan, "Justiciabilidade dos direitos sociais e econômicos: desafios e perspectivas", in José Joaquim Gomes Canotilho / Marcus Orione Gonçalves Correia / Érica Paula Barcha Correia (coords.), Direitos fundamentais sociais. São Paulo: Saraiva, 2010, 53-69; Claudio Pereira de Souza Neto, "A justiciabilidade dos direitos sociais: críticas e parâmetros", in Cláudio Pereira de Souza Neto / Daniel Sarmento (coord.), Direitos sociais: fundamentos, judicialização e direitos sociais em espécie. Rio de Janeiro: Lumen Juris, 2008, 515-551; Ana Paula de Barcellos, "Neoconstitucionalismo, direitos fundamentais e controle das políticas públicas", Revista de Direito Administrativo 240 (2005), 83-103; Ana Paula de Barcellos, "Constitucionalização das políticas públicas em matéria de direitos fundamentais: o controle político-social e o controle jurídico no espaço democrático", Revista de Direito do Estado 3 (2006), 17-54; Virgílio Afonso da Silva, "O Judiciário e as políticas públicas: entre transformação social e obstáculo à realização dos direitos sociais". In Cláudio Pereira de Souza Neto / Daniel Sarmento (coord.), Direitos sociais: fundamentos, judicialização e direitos sociais em espécie, Rio de Janeiro: Lumen Juris, 2008, 587-599; José Joaquim Gomes Canotilho, "Um olhar jurídico-constitucional sobre a judicialização da política, Revista de Direito Administrativo 245 (2007), 87-95; Daniel Wei Liang Wang, "Escassez de recursos, custos dos direitos e reserva do possível na jurisprudência do STF", Revista Direito GV 4(2) (2008), 539-568; Daniel Wei Liang Wang, "Poder Judiciário e políticas públicas de saúde: participação democrática e equidade", Cadernos Gestão Pública e Cidadania 54 (2009), 51-87; Fernanda Vargas Terrazas, "O Poder Judiciário como voz institucional dos pobres: o caso das demandas judiciais de medicamentos", Revista de Direito Administrativo 253 (2010), 79-115; Daniel Wei Liang Wang / Juliana Bonacorsi de Palma / Daniel Gama e Colombo, "Revisão judicial dos atos das agências reguladoras: uma análise da jurisprudência brasileira", in Mario Gomes Schapiro (coord.), Direito econômico regulatório, São Paulo: Saraiva, 2010, 269-328; Eduardo Pannunzio, "O Judiciário e o direito à educação", in Nina Beatriz Stocco Ranieri (coord.). Direito à educação: aspectos constitucionais. São Paulo: EDUSP, 2009, 61-88; Mônica Sifuentes, "Direito da educação e função dos juízes", in António Pedro Barbas Homem (coord.), Temas de direito da educação, Coimbra: Almedina, 2006, 41-44; André Ramos Tavares, "Direito Fundamental à educação", in Cláudio Pereira de Souza Neto / Daniel Sarmento (coord.), Direitos sociais: fundamentos, judicialização e direitos sociais em espécie. Rio de Janeiro: Lumen Juris, 2008, 771-787; Clèmerson Merlin Clève, "O desafio da efetividade dos direitos fundamentais sociais", Revista da Academia Brasileira de Direito Constitucional 3 (2003), 289-300. 
as políticas públicas nessa área demandam concretização pela via coletiva, enquanto o Poder Judiciário, estruturalmente, está organizado para a solução de litígios individuais, em que pese o desenvolvimento em curso de mecanismos de tutela jurisdicional coletiva desenvolvido nas últimas décadas, principalmente após a Constituição de 1988.

Diante do quadro teórico apresentado, o presente trabalho considera que as políticas públicas não constituem categoria jurídica própria, uma vez que podem ser implementadas por meio de um conjunto normativo heterogêneo, incluindo normas constitucionais, leis, bem como procedimentos e atos administrativos de natureza variada. Assim conjunto de normas, de diferentes níveis, que compõem o marco regulatório da educação superior, compõem uma ferramenta jurídica para a implementação de políticas públicas nessa área. ${ }^{88}$ Embora o estudo da judicialização das políticas públicas não seja o foco do presente trabalho, o posicionamento do Poder Judiciário a respeito da regulação da educação superior será aqui apresentado. ${ }^{89}$

\subsubsection{Educação e tratados internacionais}

A Declaração Universal dos Direitos Humanos de 1948, elaborada pela Organização das Nações Unidas, na opinião de Fábio Konder Comparato, retomou os ideais da Revolução Francesa, uma vez que "representou a manifestação histórica de que se formara, enfim, em âmbito universal, o reconhecimento dos valores supremos da igualdade, da liberdade e da fraternidade entre os homens". ${ }^{90}$ Esse documento, como já mencionado, consagrou em seu artigo XXVI o direito fundamental à educação:

“1. Todo homem tem direito à educação. A educação deve ser gratuita, pelo menos nos graus elementares e fundamentais. A instrução elementar será obrigatória. A instrução técnicoprofissional será generalizada; o acesso aos estudos superiores será igual para todos, em função dos méritos respectivos.

2. A instrução será orientada no sentido do pleno desenvolvimento da personalidade humana e do fortalecimento do respeito pelos direitos do homem e pelas liberdades fundamentais. A instrução promoverá a compreensão, a tolerância e a amizade entre todas as nações e grupos raciais ou religiosos, e coadjuvará as atividades das Nações Unidas em prol da manutenção da paz.

\footnotetext{
${ }^{88}$ Cf. Capítulo 4.

${ }^{89}$ Cf. 4.6 .

${ }^{90}$ Fábio Konder Comparato, A afirmação histórica dos direitos humanos, p. 223.
} 
3. Os pais têm prioridade de direito $n$ escolha do gênero de instrução que será ministrada a seus filhos." ${ }^{91}$

O processo iniciado pela Declaração de 1948 foi completado por meio da aprovação pela Assembleia Geral das Nações Unidas, em 1966, de dois pactos, ${ }^{92}$ um sobre direitos civis e políticos ${ }^{93}$ e outro sobre direitos econômicos, sociais e culturais, ${ }^{94}$ ambos tendo ingressado definitivamente no ordenamento jurídico brasileiro apenas em 1992. ${ }^{95}$ Dalmo de Abreu Dallari aponta que a Constituição brasileira, em grande medida, apresenta a influência dos dois pactos de 1966, ressaltando que se tratou de influência indireta, por meio do constitucionalismo português, uma vez que, por ocasião da elaboração da Constituição de 1988, o Brasil ainda não havia ratificado os mencionados documentos. ${ }^{96}$

\section{É importante ressaltar que o Pacto Internacional sobre Direitos Econômicos,} Sociais e Culturais, que, basicamente proclama três direitos fundamentais (educação, saúde e trabalho em condições dignas e justas), ${ }^{97}$ em seu artigo $2^{\circ}$, alínea $1,{ }^{98}$ afirma que os direitos nele declarados têm por objeto a implementação de programas de ação estatais, a serem realizados progressivamente até o máximo de recursos disponíveis de cada Estado. ${ }^{99}$ Outros documentos internacionais a respeito de direitos fundamentais, abordando a questão da educação, foram adotados pelo Brasil, como a Convenção relativa à Luta contra a

\footnotetext{
${ }^{91}$ Organização das Nações Unidas, Declaração Universal dos Direitos Humanos, 1948 apud Fábio Konder Comparato, A afirmação histórica dos direitos humanos, p. 236.

${ }_{92}^{92}$ Fábio Konder Comparato, A afirmação histórica dos direitos humanos, p. 222.

${ }^{93}$ Trata-se do Pacto Internacional sobre Direitos Civis e Políticos, ratificado pelo Brasil pelo Decreto Legislativo $\mathrm{n}^{\circ} 226$, de 12 de dezembro de 1991, e promulgado pelo Decreto ${ }^{\circ} 592$, de 6 de dezembro de 1992 (cf. Fábio Konder Comparato, A afirmação histórica dos direitos humanos, p. 275).

${ }^{94}$ Trata-se do Pacto Internacional sobre Direitos Econômicos, Sociais e Culturais, ratificado pelo Brasil pelo Decreto Legislativo $\mathrm{n}^{\circ}$ 226, de 12 de dezembro de 1991, e promulgado pelo Decreto $\mathrm{n}^{\circ}$ 592, de 6 de dezembro de 1992 (cf. Fábio Konder Comparato, A afirmação histórica dos direitos humanos, p. 275).

${ }^{95}$ Fábio Konder Comparato, A afirmação histórica dos direitos humanos, p. 275.

${ }^{96}$ Cf. Dalmo de Abreu Dallari, "Os direitos fundamentais na Constituição brasileira", Revista da Faculdade de Direito da Universidade de São Paulo 88 (1993), p. 431.

${ }^{97}$ Cf. Dalmo de Abreu Dallari, "Educação e Preparação para a Cidadania", in Maria Victoria de Mesquita / Gilberto Bercovici / Claudineu de Melo (orgs.), Direitos Humanos, Democracia e República, São Paulo: Quartier Latin, 2009, pp. 343-344.

${ }_{98}$ Assim dispõe o artigo $2^{\circ}$, alínea 1: "Cada Estado-Parte do presente Pacto compromete-se a adotar medidas, tanto por esforço próprio como pela assistência e cooperação internacionais, principalmente nos planos econômico e técnico, até o máximo de seus recursos disponíveis, que visem a assegurar, progressivamente, por todos os meios apropriados, o pleno exercício dos direitos reconhecidos no presente Pacto, incluindo, em particular, a adoção de medidas legislativas. (Organização das Nações Unidas, Pacto Internacional sobre Direitos Econômicos, Sociais e Culturais, 1966 apud Fábio Konder Comparato, A afirmação histórica dos direitos humanos, p. 284.

${ }^{99}$ Cf. Fábio Konder Comparato, A afirmação histórica dos direitos humanos, p. 276.
} 
Discriminação no campo do Ensino, adotada pela Conferência Geral da UNESCO (1960), ${ }^{100}$ e a Convenção Americana de Direitos Humanos (1969). ${ }^{101}$

Conforme já mencionei em artigo que analisou a Convenção da UNESCO relativa à luta contra a discriminação no campo do ensino, ${ }^{102}$ para compreensão dos princípios trazidos por tratados internacionais sobre a educação, norteadores do combate à discriminação no campo educacional, faz-se necessária a análise da posição que ocupam tais documentos no ordenamento jurídico brasileiro, a fim de estabelecer sua relação com as disposições contidas na Constituição brasileira de 1988.

A Emenda Constitucional no 45, de 30 de dezembro de 2004, que promoveu a chamada Reforma do Judiciário, buscou solucionar a controvérsia existente a respeito da posição hierárquica ocupada pelos tratados internacionais sobre direitos humanos, ao inserir o $\S 3^{\circ}$, no artigo $5^{\circ}$ da Constituição, ${ }^{103}$ estabelecendo a possibilidade de ratificação de tratados internacionais sobre direitos fundamentais em procedimento idêntico ao da aprovação de emendas à Constituição, ${ }^{104}$ para que eles tenham natureza jurídica equivalente a estas. Por essa razão, os tratados internacionais sobre direitos humanos ratificados por esse procedimento adquirem posição jurídica de normas constitucionais. ${ }^{105}$ Por outro lado, tradicionalmente, o Supremo Tribunal Federal entendia que os tratados internacionais a respeito de direitos fundamentais, aprovados pelo processo legislativo ordinário, constituíam normas infraconstitucionais.

\footnotetext{
${ }^{100}$ Promulgada pelo Brasil por meio do Decreto $\mathrm{n}^{\circ}$ 63.223, de setembro de 1968 (cf. Claudio Mendonça Braga, "A Convenção da UNESCO contra a discriminação no ensino e as ações afirmativas no Brasil", in Nina Beatriz Stocco Ranieri (coord.), Direito à educação: igualdade e discriminação no ensino. São Paulo: EDUSP, 2010, pp. 93).

${ }^{101}$ Promulgada pelo Brasil por meio do Decreto nº 678, de 6 de novembro de 1992 (cf. Fábio Konder Comparato, A afirmação histórica dos direitos humanos, p. 362).

${ }^{102}$ Cf. Claudio Mendonça Braga, “A Convenção da UNESCO contra a discriminação no ensino e as ações afirmativas no Brasil”, pp. 95-96.

${ }^{103}$ Constituição Federal:

"Art. $5^{\circ}[\ldots]$

$\S 3^{\circ}$ Os tratados e convenções internacionais sobre direitos humanos que forem aprovados, em cada Casa do Congresso Nacional, em dois turnos, por três quintos dos votos dos respectivos membros, serão equivalentes às emendas constitucionais."

${ }_{104}^{104}$ Constituição da República Federativa do Brasil, artigo 60, $\S 2^{\circ}$.

105 A Convenção sobre os Direitos das Pessoas com Deficiência e seu Protocolo Facultativo, assinados em Nova York, em 30 de março de 2007, foi ratificado pelo Congresso Nacional brasileiro por meio do Decreto Legislativo $n^{\circ} 186$, de 9 de julho de 2008, conforme o procedimento do $\S 3^{\circ}$ do artigo $5^{\circ}$ da Constituição, e foi promulgado por meio do Decreto $\mathrm{n}^{\circ}$ 6.949, de 25 de agosto de 1999. Trata-se, portanto, de norma de status constitucional.
} 
No entanto, recentes decisões do Supremo Tribunal Federal ${ }^{106}$ superaram a tese anteriormente firmada, passando entender, por maioria de votos, ${ }^{107}$ que tratados internacionais sobre direitos fundamentais possuem status jurídico infraconstitucional, porém supralegal. Encontram-se, portanto, em posição hierárquica inferior às normas constitucionais, porém acima da legislação ordinária.

Dessa maneira, ainda que se considere que tratados internacionais a respeito de educação (que se configura como direito fundamental) não tenham ingressado no ordenamento jurídico brasileiro com o status de norma constitucional, de acordo com o posicionamento atual do Supremo Tribunal Federal, eles são dotadas de supralegalidade, o que a torna hierarquicamente superior a qualquer outra norma legal brasileira. Portanto, a legislação ordinária não poderá afastar a aplicação desses documentos, uma vez que se trata de direito vigente, com eficácia supralegal.

\subsubsection{Tratamento constitucional do direito à educação}

Passa-se, então, a analisar a evolução do tratamento constitucional dado à educação ao longo de suas constituições e as disposições a respeito contidas na atual Constituição vigente.

\subsubsection{Evolução constitucional do tratamento da educação}

O presente subcapítulo buscará apresentar, de forma geral, as principais disposições constitucionais brasileiras relativas à educação, a partir do estudo da evolução do tratamento da matéria dado historicamente pelas constituições brasileiras, culminando nas normas contidas na atual Constituição - a que confere maior detalhamento do assunto. O estudo do tratamento constitucional dado à educação é ilustrativo para a percepção de sua evolução, dada a peculiaridade existente no Brasil da ocorrência de substituição da constituição a cada ruptura institucional. Essa característica brasileira se distingue da tradição de outros países latino-americanos, como a Argentina, na qual rupturas institucionais frequentes não provocaram a alteraram da ordem constitucional vigente.

\footnotetext{
${ }^{106}$ STF, RE 466343, julgado em conjunto com RE 349703, HC 87585e HC92566 (DJ 05.06.2009).

$107 \mathrm{O}$ voto vencido, do Min. Celso de Mello, posicionava-se no sentido de considerar que tratados internacionais de direitos humanos, aprovados antes da EC 45/2004, teriam status de norma materialmente constitucional (cf. STF, RE 466343, pp. 1211-1265).
} 
A ordem jurídica constitucional brasileira foi inaugurada em 1824 com a Constituição do Império, outorgada por Dom Pedro I após a dissolução da Assembleia Constituinte. Essa Constituição, de cunho eminentemente liberal, apresenta poucas normas relativas à educação, sendo certo que, limitou-se a garantia da gratuidade de instrução do ensino primário e atribuiu aos colégios e universidades o ensino das ciências, belas artes e letras. ${ }^{108}$ Apesar da previsão do direito ao ensino fundamental, a efetivação desse direito foi mínima no período de vigência dessa constituição.

Posteriormente, após a proclamação da República, foi promulgada a Constituição 1891, de cunho eminentemente liberal, que operou a separação entre Estado e Igreja. Essa medida repercutiu no campo da educação, com o estabelecimento do ensino leigo nos estabelecimentos públicos. ${ }^{109}$ Além disso, em matéria educacional, foi atribuída à União a competência legislativa privativa para o estabelecimento de normas organizativas do ensino superior, ${ }^{110}$ e a de, por meio do Congresso Nacional, criar instituições de ensino superior e prover a instrução secundária no Distrito Federal - competências estas não privativas. $^{111}$

A Constituição promulgada em 1934 inovou no ordenamento jurídico brasileiro ao estabelecer no plano constitucional a existência de direitos sociais, ${ }^{112}$ sob influência da Constituição de Weimar, de 1919. ${ }^{113}$ Essa Constituição foi a primeira a tratar a educação de forma sistematizada e detalhada, prescrevendo uma planificação nacional, por meio de um plano nacional de educação, com vigência determinada e renovável, ${ }^{114}$ e a competência privativa da união para traçar as diretrizes da educação nacional, ${ }^{115}$ atribuição foi sendo mantida pelas sucessivas constituições. Além disso, previu-se a criação do Conselho de Nacional de Educação, ${ }^{116}$ bem como foram estabelecidas regras principiológicas e de organização, ${ }^{117}$ que orientavam a o desenvolvimento da educação, podendo ser destacadas: a gratuidade de ensino fundamental e a tendência de gratuidade dos demais níveis educacionais. Apesar de o Estado manter-se como laico, houve a

${ }^{108}$ Constituição Política do Império do Brasil, 1824, artigo 179, XXXII e XXXIII.

${ }^{109}$ Constituição da República dos Estados Unidos do Brasil, de 1891, artigo 72, § $6^{\circ}$.

${ }^{110}$ Constituição da República dos Estados Unidos do Brasil, de 1891, artigo 34, $30^{\circ}$.

${ }^{111}$ Constituição da República dos Estados Unidos do Brasil, de 1891, artigo 35, $3^{\circ}$ e $4^{\circ}$.

112 Paradoxalmente, apesar de incluir direitos sociais - ligados à dignidade da pessoa humana - a

Constituição de 1934 trouxe a previsão de estímulo à educação eugênica (artigo 138, “b”).

${ }^{113}$ Cf. 1.2.2.

${ }^{114}$ Constituição da República dos Estados Unidos do Brasil, 1934, artigo 150, "a".

${ }^{115}$ Constituição da República dos Estados Unidos do Brasil, 1934, artigo 5º XIV.

${ }^{116}$ Constituição da República dos Estados Unidos do Brasil, 1934, artigo 152.

${ }^{117}$ Constituição da República dos Estados Unidos do Brasil, 1934, artigos 149 e 150. 
previsão de ensino religioso de matrícula facultativa, ${ }^{118}$ disposição que seria mantida nas seguintes constituições.

A Constituição de 1934 trouxe as primeiras disposições a respeito da atividade de regulação da educação superior, ao estabelecer, como competência da União, "determinar as condições de reconhecimento oficial dos estabelecimentos de ensino secundário e complementar deste e dos institutos de ensino superior, exercendo sobre eles a necessária fiscalização"119. Além disso, foi prevista a primeira disposição constitucional relativa à necessidade de reconhecimento de estabelecimentos particulares de ensino, mas que não se referia diretamente à busca da qualidade, mas se vinculava à observância dos direitos sociais dos professores, por meio do "reconhecimento dos estabelecimentos particulares de ensino somente quando assegurarem a seus professores a estabilidade, enquanto bem servirem, e uma remuneração condigna". ${ }^{120}$

A Constituição de 1937, outorgada por Getúlio Vargas, manteve a competência privativa da União para fixar bases e determinar os quadros da educação nacional, ${ }^{121}$ mas apresentou retrocesso em relação ao ensino primário, estabelecendo restrições à gratuidade. ${ }^{122}$ Sem estabelecer normas de regulação, estabeleceu-se que o ensino seria livre à iniciativa individual e à de associações ou pessoas coletivas, públicas e particulares. ${ }^{123}$

A Constituição de 1946 manteve como atribuição da União legislar sobre diretrizes e bases da educação, ${ }^{124}$ mantendo a obrigatoriedade do ensino primário e restabelecendo sua gratuidade nos estabelecimentos oficiais. ${ }^{125}$ Foi mantida a liberdade de desenvolvimento de atividades educacionais pela iniciativa privada, respeitadas as leis regulamentadoras. ${ }^{126}$ Dessa forma, embora não contivesse normas relativas à regulação da educação, a Constituição de 1946, de forma expressa, delegou sua disciplina ao legislador infraconstitucional.

\footnotetext{
${ }^{118}$ Constituição da República dos Estados Unidos do Brasil, 1934, artigo 153.

${ }^{119}$ Constituição da República dos Estados Unidos do Brasil, 1934, artigo 150, "b".

${ }^{120}$ Constituição da República dos Estados Unidos do Brasil, 1934, artigo 150, "f".

${ }^{121}$ Constituição dos Estados Unidos do Brasil, 1937, artigo 15, IX, e artigo 16, XXIV.

122 Constituição dos Estados Unidos do Brasil, 1937, artigo 130.

${ }^{123}$ Constituição dos Estados Unidos do Brasil, 1937, artigo 28.

${ }^{124}$ Constituição dos Estados Unidos do Brasil, 1946, artigo 5, XV, "d" e artigo 31, V,"b".

${ }^{125}$ Constituição dos Estados Unidos do Brasil, 1946, artigo 168, I e II.

${ }^{126}$ Constituição dos Estados Unidos do Brasil, 1946, artigo 167.
} 
A Constituição de 1967 manteve a competência da União para estabelecer planos nacionais de educação e legislar sobre diretrizes e bases da educação nacional. ${ }^{127}$ Prescreveu-se, também, que o ensino dos sete aos catorze anos era obrigatório para todos e gratuito nos estabelecimentos primários oficiais. ${ }^{128}$ A liberdade da atividade educacional desenvolvida pela iniciativa privada foi mantida, com a previsão de amparo técnico e financeiro dos poderes públicos, inclusive mediante a concessão de bolsas de estudo. ${ }^{129}$

A Emenda Constitucional $\mathrm{n}^{\mathrm{o}}$ 1, de 17 de outubro de 1969, que para muitos estudiosos tratou-se de uma nova constituição, ${ }^{130}$ por ter reformulado a maior parte da constituição vigente, praticamente repetiu as disposições contidas na Constituição de 1967, com pequenas alterações de redação.

Percebe-se que a disciplina constitucional da educação no Brasil se desenvolveu desde a primeira constituição, ganhando maior atenção e sistematização a partir da Constituição de 1934, com um capítulo totalmente a ela dedicado, influenciada por pensadores do movimento dos pioneiros da Escola Nova, tendo à frente Fernando de Azevedo e Anísio Teixeira. ${ }^{131}$ A evolução da compreensão do fenômeno da educação pode ser percebida pela evolução da terminologia progressivamente utilizada nas constituições brasileiras: instrução, ensino e educação, que, embora muitas vezes sejam tratados como se termos sinônimos fossem, apresentam dimensões distintas: o conceito de educação é mais amplo do que o de ensino, e o deste, mais amplo do que o da mera instrução. ${ }^{132}$ Essa evolução culminou na Constituição de 1988, que conferiu tratamento mais detalhado, e para alguns até, conflitante, ${ }^{133}$ à educação.

\subsubsection{Educação na Constituição de 1988}

No Brasil, pela Constituição de 1988, o direito à educação atualmente é reconhecido como direito social informado pelo princípio da universalidade, ${ }^{134}$ uma vez

\footnotetext{
${ }^{127}$ Constituição do Brasil, 1967, artigo 8, XVI e XVII, “q”.

${ }^{128}$ Constituição do Brasil, 1967, artigo 168, $\$ 3^{\circ}$, I e II.

${ }^{129}$ Constituição do Brasil, 1967, artigo $168, \S 2^{\circ}$.

${ }^{130}$ Para José Afonso da Silva, "teórica e tecnicamente não se tratou de emenda, mas de nova constituição" (cf. José Afonso da Silva, Curso de direito constitucional positivo, p. 87).

${ }^{131}$ Cf. Edivaldo M. Boaventura, "A Constituição e a educação brasileira”, p. 30.

${ }^{132}$ Mônica Sifuentes, Direito fundamental à educação, p. 37.

${ }^{133}$ Cf. Edivaldo M. Boaventura, "A Constituição e a educação brasileira", p. 30.

134 José Afonso da Silva, Comentário contextual à Constituição, 7. ed., São Paulo: Malheiros, 2010, p. 801.
} 
que a educação constitui-se em direito de todos e dever do Estado e da família, bem como deve ser promovida e incentivada com a colaboração da sociedade. ${ }^{135}$

O tratamento da educação como fenômeno complexo é verificado na Constituição brasileira de 1988 , que trouxe a opção pela formação integral, ${ }^{136}$ ao estabelecer que a educação tem três objetivos fundamentais: (a) o pleno desenvolvimento da pessoa, (b) o preparo da pessoa para o exercício da cidadania e (c) a qualificação da pessoa para o trabalho. ${ }^{137}$ Estes objetivos, que integram, respectivamente, valores antropológico-culturais, políticos e profissionais, ${ }^{138}$ relacionam-se entre si, a fim de estabelecer uma compreensão global da educação.

É fundamental a contextualização dos objetivos específicos relativos à educação em relação aos objetivos fundamentais da República Federativa do Brasil: (a) construir uma sociedade livre, justa e solidária; (b) garantir o desenvolvimento nacional; (c) erradicar a pobreza e a marginalização e reduzir as desigualdades sociais e regionais; e (d) promover o bem de todos, sem preconceitos de origem, raça, sexo, cor, idade e quaisquer outras formas de discriminação. ${ }^{139}$ Indubitavelmente, educação exerce papel fundamental para que se alcance estes objetivos, possuindo relação direta com cada um deles. $^{140}$

Para atingir tais objetivos, a Constituição estabelece os princípios constitucionais setoriais ou especiais ${ }^{141}$ relativos à atividade educacional, indicando as bases sobre as quais o ensino deve ser ministrado: (a) igualdade de condições para o acesso e permanência na escola; (b) liberdade de aprender, ensinar, pesquisar e divulgar o pensamento, a arte e o saber; (c) pluralismo de ideias e de concepções pedagógicas, e coexistência de instituições públicas e privadas de ensino; (d) gratuidade do ensino público em estabelecimentos oficiais; (e) valorização dos profissionais da educação escolar, garantidos, na forma da lei, planos de carreira, com ingresso exclusivamente por concurso

\footnotetext{
${ }^{135}$ Constituição da República Federativa do Brasil, artigo 205, caput.

${ }_{136}^{136}$ Mônica Sifuentes, Direito fundamental à educação, p. 29.

${ }^{137}$ Constituição da República Federativa do Brasil, artigo 205, caput.

${ }^{138}$ Cf. José Afonso da Silva, Comentário contextual à Constituição. 7. ed. São Paulo: Malheiros, 2010, p. 801.

${ }^{139}$ Constituição da República Federativa do Brasil, artigo $3^{\circ}$.

${ }^{140}$ Cf. Claudio Mendonça Braga, "A Convenção da UNESCO contra a discriminação no ensino e as ações afirmativas no Brasil", p. 97.

${ }^{141}$ Princípios constitucionais setoriais ou especiais são aqueles incidem sobre um conjunto determinado de normas (cf. Luís Roberto Barroso / Ana Paula de Barcellos, "O começo da História: a nova interpretação constitucional e o papel dos princípios no Direito brasileiro", in Virgílio Afonso da Silva (org.),
} Interpretação constitucional, São Paulo: Malheiros, 2005, p. 305). 
público de provas e títulos, aos das redes públicas; (f) gestão democrática do ensino público, na forma da lei; (g) garantia de padrão de qualidade; e (h) piso salarial profissional nacional para os profissionais da educação escolar pública, nos termos de lei federal. ${ }^{142}$

Luiz Alberto David Araújo e Vidal Serrano Nunes Júnior indicam a importância do estabelecimento desses princípios, como norteadores de toda atividade educacional:

"Nesse sentido o art. 206 da Constituição contempla a principiologia do ensino, princípios pródigos em cientificidade e largos em seus objetivos, que servirão de vetores para toda a atividade legislativa, administrativa e judiciária, não podendo nunca qualquer um dos titulares dessas atividades agir em desacordo com tais princípios." ${ }^{143}$

Em relação à efetivação da prestação da atividade educacional por parte do Estado, a Constituição apresenta as seguintes garantias: ${ }^{144}$ (a) educação básica obrigatória e gratuita dos quatro aos dezessete anos de idade, assegurada inclusive sua oferta gratuita para todos os que a ela não tiveram acesso na idade própria; ${ }^{145}$ (b) progressiva universalização do ensino médio gratuito; ${ }^{146}$ (c) atendimento educacional especializado aos portadores de deficiência, preferencialmente na rede regular de ensino; (d) educação infantil, em creche e pré-escola, às crianças até cinco anos de idade ${ }^{147}$ (e) acesso aos níveis mais elevados do ensino, da pesquisa e da criação artística, segundo a capacidade de cada um; (f) oferta de ensino noturno regular, adequado às condições do educando; (g) atendimento ao educando, em todas as etapas da educação básica, por meio de programas suplementares de material didático-escolar, transporte, alimentação e assistência à saúde. ${ }^{148}$

Além disso, em busca da efetividade do direito à educação, prescreve-se que o acesso ao ensino obrigatório e gratuito é direito público subjetivo, bem como que o nãooferecimento do ensino obrigatório pelo Poder Público, ou sua oferta irregular, importa responsabilidade da autoridade competente. ${ }^{149}$

\footnotetext{
${ }^{142}$ Constituição da República Federativa do Brasil, artigo 206.

${ }^{143}$ Luiz Alberto David Araújo / Vidal Serrano Nunes Júnior, Curso de direito constitucional, 9. ed., São Paulo: Saraiva, 2005, p. 475.

${ }^{144}$ Constituição da República Federativa do Brasil, artigo 208.

${ }^{145}$ Com redação dada pela Emenda Constitucional no 59 , de 2009.

${ }^{146}$ Com redação dada pela Emenda Constitucional no 14, de 1996.

${ }^{147}$ Com redação dada pela Emenda Constitucional no 53 , de 2006.

${ }^{148}$ Com redação dada pela Emenda Constitucional no 59 , de 2009.

${ }^{149}$ Constituição da República Federativa do Brasil, artigo 208, $\S \S 1^{\circ}$ e $2^{\circ}$.
} 
Nota-se que o artigo 208 sofreu muitas alterações por meio de emendas constitucionais, que se guiaram no sentido de, progressivamente, aumentar o dever do Estado de prestar o serviço de educação, uma vez que certas etapas do cumprimento da obrigação do Estado já tivessem sido minimamente cumpridas. É o caso do ensino fundamental, que, por ter sido quase universalizado no país, passou a demandar do Estado a universalização da etapa seguinte do sistema educacional: o ensino médio. Por essa razão, a reforma constitucional que estabeleceu como educação básica obrigatória e gratuita aquela prestada às pessoas dos quatro aos dezessete anos de idade, estabelecendo como direito público subjetivo a educação básica, que compreende os ensinos fundamental e médio, e não apenas ao ensino fundamental, conforme previsão do texto constitucional original.

No entanto, é necessário ressaltar que o estabelecimento da educação básica obrigatória e gratuita dos quatro aos dezessete anos de idade deverá ser implementado progressivamente, até 2016, nos termos do Plano Nacional de Educação e com apoio técnico e financeiro da União, ${ }^{150}$ o que vem a corroborar a ideia de progressividade dos direitos fundamentais e nos permite vislumbrar a possibilidade de que, no futuro, o ensino superior também se configure como direito público subjetivo.

A Constituição também prescreve o princípio da autonomia universitária, consubstanciada na autonomia didático-científica, administrativa e de gestão financeira e patrimonial de que dispõe as instituições educacionais organizadas desta maneira, com a obediência ao princípio da indissociabilidade entre ensino, pesquisa e extensão. ${ }^{151}$ Trata-se de princípio muito importante a ser estudado pelo presente trabalho. ${ }^{152}$

Além dos princípios mencionados, existe a previsão contida no artigo 209 da Constituição, que estabelece que o ensino é livre à iniciativa privada, atendidas as seguintes condições: (a) cumprimento das normas gerais da educação nacional, e (b) autorização e avaliação de qualidade pelo Poder Público. Trata-se do dispositivo fundamental no presente trabalho: de que maneira o marco regulatório que dispõe sobre a relação existente entre a avaliação da qualidade e a regulação da atividade educacional por meio de atos autorizativos pode servir para consolidar a efetivação dos demais princípios relativos ao direito à educação?

\footnotetext{
${ }^{150}$ Cf. artigo 6 ${ }^{\circ}$, da Emenda Constitucional no 59/2009.

${ }^{151}$ Constituição da República Federativa do Brasil, artigo 207, caput.

${ }^{152}$ Cf. 2.2.2.
} 
A Constituição brasileira de 1988 estabeleceu a educação como direito social, visando à consecução de determinados objetivos, observando o atendimento de determinados princípios, a ser atendido por meio de um sistema que envolve todas as entidades integrantes da Federação, que detém competências legislativas e materiais para, estabelecerem normas jurídicas que regulem a atividade educacional, bem como que organizem estruturas administrativas aptas a atingir as finalidades constitucionalmente estabelecidas em matéria educacional.

No que diz respeito às competências legislativas, foi mantida a competência da União para legislar sobre diretrizes e bases da educação nacional, ${ }^{153}$ tornando a competência legislativa a respeito do assunto concorrente entre a União - limitada à produção de normas gerais - e os Estados e o Distrito Federal, competentes para suplementar a competência federal. ${ }^{154}$ A esse respeito, cabe aos Municípios suplementar a legislação federal e estadual no que couber, a fim de atender ao interesse local. ${ }^{155}$

No que diz respeito às competências materiais relativas à educação, a Constituição estabelece que a União, os Estados, o Distrito Federal e os Municípios organizarão em regime de colaboração seus sistemas de ensino. ${ }^{156}$ Nesse sentido, cabe à União financiar as instituições de ensino públicas federais (de educação superior) e exercer, em matéria educacional, função redistributiva e supletiva, de forma a garantir equalização de oportunidades educacionais e padrão mínimo de qualidade do ensino mediante assistência técnica e financeira aos Estados, ao Distrito Federal e aos Municípios. ${ }^{157}$ Aos Estados e ao Distrito Federal cabe a atuação prioritária no ensino fundamental e médio ${ }^{158}$ ao passo que aos Municípios cabe a atuação prioritária no ensino fundamental e na educação infantil. ${ }^{159}$ Esses dispositivos estabelecem os parâmetros para o estabelecimento dos sistemas de ensino de cada unidade da Federação. ${ }^{160}$

A fim de que haja recursos necessários para o desenvolvimento dessas importantes atividades, de forma a resguardar a atividade educacional das conjunturas políticas que potencialmente poderiam reduzir o volume de investimentos nessa área, a

\footnotetext{
${ }^{153}$ Constituição da República Federativa do Brasil, artigo 22, XXIV.

${ }^{154}$ Constituição da República Federativa do Brasil, artigo 24, IX.

155 Constituição da República Federativa do Brasil, artigo 30, I e II.

${ }^{156}$ Constituição da República Federativa do Brasil, artigo 211, caput.

${ }^{157}$ Constituição da República Federativa do Brasil, artigo 211, § $1^{\text {o }}$.

${ }^{158}$ Constituição da República Federativa do Brasil, artigo 211, § $3^{\circ}$.

${ }^{159}$ Constituição da República Federativa do Brasil, artigo 211, § $2^{\circ}$.

${ }^{160}$ Cf. 1.3.1.1.
} 
Constituição estabelece uma aplicação mínima da receita anual resultante de impostos na manutenção e desenvolvimento do ensino - dezoito por cento, para União, e vinte e cinco por cento, para os Estados, o Distrito Federal e os Municípios. ${ }^{161}$

\subsubsection{Educação como direito público subjetivo}

A Constituição brasileira de 1988 estabelece que o acesso ao ensino obrigatório e gratuito é direito público subjetivo. ${ }^{162}$ Trata-se de um importante dispositivo, tendo em vista a controvérsia jurídica existente a respeito da configuração dos direitos sociais como direito público subjetivo. No caso da educação - ensino obrigatório e gratuito - sua caracterização como direito subjetivo não pode ser negada - caracterizando-se tal prestação como serviço público essencial, ${ }^{163}$ que deve ser prestado de forma regular. ${ }^{164}$ Ressalte-se que até 1988, apesar da obrigatoriedade de matrícula, a educação fundamental não constituía direito público subjetivo, uma vez que não havia instrumento jurídico hábil a garantia de sua exigibilidade. ${ }^{165}$

No entanto, embora a doutrina trate o direito público subjetivo à educação no nível fundamental, por conta da Emenda Constitucional no 59, de 11 de novembro de 2009, o acesso ao ensino médio também constitui direito público subjetivo, a ser efetivado progressivamente até $2016 .^{166}$

Por se tratar de direito público subjetivo, a prestação da educação básica é dever do Estado, fazendo com que a Constituição brasileira tenha estabelecido uma vinculação mínima de receitas, bem como a responsabilização da autoridade competente. A esse respeito, Esther de Figueiredo Ferraz, mesmo sob a égide da Constituição anterior, estabelecia a relação necessária entre o direito subjetivo à educação e o dever do Estado em prestá-la: “o direito à educação só adquire consistência quando se haja firmado o correspondente dever de dar educação, e dá-la gratuitamente aos que, de outra forma, não poderiam exercê-lo". ${ }^{167}$

\footnotetext{
${ }^{161}$ Constituição da República Federativa do Brasil, artigo 212.

162 Constituição da República Federativa do Brasil, artigo 208, § $1^{\text {o }}$.

${ }^{163}$ Cf. Mônica Sifuentes, Direito fundamental à educação, p. 128.

${ }^{164}$ Cf. Mônica Sifuentes, Direito fundamental à educação, pp. 133-134.

${ }^{165}$ Cf. Mônica Sifuentes, Direito fundamental à educação, pp. 126-127.

${ }^{166}$ Cf. 1.3.1.2.

${ }^{167}$ Esther de Figueiredo Ferraz, Alternativas da educação, Rio de Janeiro: José Olympio, 1976, p. 9.
} 
Clarice Seixas Duarte aponta o tratamento diferenciado dado para o ensino fundamental (e, atualmente, ao médio também) em relação ao conferido aos demais direitos sociais:

"Na realidade, o fato de a Constituição atual ter enunciado de forma expressa o direito público subjetivo como regime específico do direito ao ensino fundamental conferiu aos indivíduos, irrecusavelmente, uma pretensão e uma ação para exigirem seus direitos, o que, no caso de outros direitos sociais, vem suscitando maiores objeções, pois o seu objeto primário é a realização de políticas públicas."

A educação superior não é tratada de forma expressa pela Constituição como direito público subjetivo, mas, dado o caráter progressivo dos direitos sociais, poderá vir a sê-lo, a exemplo do que ocorreu com o ensino médio. No entanto, ao menos pode-se invocar como direito subjetivo o direito à implementação de políticas públicas pelo Estado visando à efetivação de tais direitos. ${ }^{169}$

\subsubsection{Educação e desenvolvimento}

Conforme visto, a educação tem relação direta com a consecução dos objetivos da República Federativa do Brasil, entre os quais se encontra o desenvolvimento nacional, uma vez que uma das externalidades positivas da atividade educacional é a relação direta entre níveis educacionais e desenvolvimento econômico e social. Essa relação, segundo Esther de Figueiredo Ferraz, já é percebida há muito tempo:

“Já há quase 200 anos Adam Smith, na Escócia, e há cerca de 100 anos Alfred Marshall, na Inglaterra, haviam intuído o fato de que a educação, além de bem de consumo, é um autêntico investimento, quando afirmaram, o primeiro, que uma nação deveria esforçar-se, em benefício próprio, para que seu povo fosse inteligente, engenhoso e dinâmico, e o segundo, que o mais valioso capital é o que se investe em seres humanos, "in people”.,"170

Nesse sentido, há uma relação de interdependência entre educação e desenvolvimento, pois, se sem educação não há desenvolvimento, por outro lado, "o desenvolvimento é condição necessária para a realização do bem-estar social. O Estado é,

${ }^{168}$ Clarice Seixas Duarte, "Direito público subjetivo e políticas educacionais”, São Paulo em Perspectiva 18 (2004), p. 116.

${ }_{169}$ Cf. Clarice Seixas Duarte, "Direito público subjetivo e políticas educacionais", p. 117.

${ }^{170}$ Esther de Figueiredo Ferraz, Alternativas da educação, pp. 10-11. 
através do planejamento, o principal promotor do desenvolvimento". ${ }^{171}$ Por esse motivo, cabe ao Estado o papel de coordenação, tendo em vista a dimensão política da superação do subdesenvolvimento - explicitada pelos objetivos nacionais e prioridades sociais enfatizados pelo próprio Estado, ${ }^{172}$ que, para desempenhar essa função, deve ter autonomia frente aos grupos sociais, bem como ampliar suas funções e readequar seus órgãos e estrutura. $^{173}$

Pinto Ferreira entende que a educação é o maior fator do desenvolvimento, tendo em vista que os países desenvolvidos têm um alto nível de saber, conhecimento e tecnologia avançada. Por essa razão são grandes as vantagens oferecidas pela educação de qualidade oferecida em todos os níveis. ${ }^{174} \mathrm{Na}$ mesma linha, apontam Carlos Tünnermann Bernheim e Marilena de Souza Chauí:

\begin{abstract}
"Uma das características da sociedade contemporânea é o papel central do conhecimento nos processos de produção, ao ponto do qualificativo mais freqüente hoje empregado ser o de sociedade do conhecimento. Estamos assistindo à emergência de um novo paradigma econômico e produtivo no qual o fator mais importante deixa de ser a disponibilidade de capital, trabalho, matérias-primas ou energia, passando a ser o uso intensivo de conhecimento e informação." 175
\end{abstract}

A relação entre o desenvolvimento da educação de qualidade e o desenvolvimento nacional demanda a necessidade do aparelhamento do Estado para exercer sua função. Nesse aspecto, a educação superior de qualidade possui um relevante papel de indutor do desenvolvimento nacional, merecendo, dessa maneira, um tratamento jurídico adequado. ${ }^{176}$

\title{
1.3. Direito da educação
}

Tendo em vista que o direito à educação, como direito fundamental social, acarreta o dever do Estado em prover sua prestação de forma organizada, há a necessidade

${ }^{171}$ Gilberto Bercovici, Constituição econômica e desenvolvimento: uma leitura a partir da Constituição de 1988. São Paulo: Malheiros, 2005, p. 51.

${ }^{172}$ Cf. Gilberto Bercovici, Constituição econômica e desenvolvimento, p. 51.

173 Cf. Gilberto Bercovici, "Desenvolvimento, Estado e Administração Pública", in José Eduardo Martins Cardozo / João Eduardo Lopes Queiroz / Márcia Walquíria Batista dos Santos (orgs.), Curso de Direito Administrativo Econômico. Vol II. São Paulo: Malheiros, 2006, p. 26.

${ }^{174}$ Cf. Pinto Ferreira, "Educação e Constituinte", Revista de Informação Legislativa 92 (1986), p. 174.

175 Carlos Tünnermann Bernheim / Marilena de Souza Chauí, Desafios da universidade na sociedade do conhecimento: cinco anos depois da conferência mundial sobre educação superior, Brasília: UNESCO, 2008, p. 7.

${ }^{176}$ Cf. Capítulo 4. 
de estruturação de um arcabouço de normas jurídicas, que aqui é denominado direito da educação, que disciplina a forma pela qual a educação deve ser prestada. ${ }^{177}$ As disposições jurídicas fundamentais que disciplinam a prestação da atividade educacional como um todo passa a ser analisada no presente subcapítulo.

\subsubsection{Lei de Diretrizes e Bases da Educação Nacional (LDB)}

A Lei no 9.394/1996, conhecida como Lei de Diretrizes e Bases da Educação Nacional (LDB), fornece a disciplina jurídica básica da educação escolar. Trata-se de lei nacional, fundamentada na competência da União em legislar sobre diretrizes e bases da educação nacional, que organiza a educação como sistema que envolve todos os entes federativos.

A promulgação dessa lei resultou de um amplo debate, que envolveu não apenas o Congresso Nacional, mas também a sociedade em geral, com destaque para o meio acadêmico. Ao final, foi aprovado o projeto de lei substitutivo, de autoria do Senador Darcy Ribeiro, que, no que se refere à educação superior, incorporou a avaliação como instrumento central e a autonomia como elemento-chave da universidade. ${ }^{178}$

A LDB apresenta, inicialmente, a disciplina jurídica dos princípios e fins da educação nacional, ${ }^{179}$ bem como do direito à educação e do dever de educar. ${ }^{180}$ Em grande medida, essas disposições traduzem os preceitos constitucionalmente estabelecidos para a matéria. Além disso, a LDB traz disposições relativas à organização da educação nacional, ${ }^{181}$ disciplinando a competência de cada ente da Federação em matéria educacional, criando os sistemas de ensino, ${ }^{182}$ bem como classificando as instituições privadas que prestam a atividade educacional. ${ }^{183}$ A LDB também estabelece as os níveis e modalidades de ensino, que serão abordados em subcapítulo próprio. ${ }^{184}$

\footnotetext{
${ }^{177}$ Cf. 1.1 .

${ }^{178}$ Cf. Magno Federici Gomes, "Educação superior privada como serviço de utilidade pública”, p. 267.

${ }^{179} \mathrm{LDB}$, artigos $2^{\circ}$ e $3^{\circ}$.

${ }^{180} \mathrm{LDB}, \operatorname{artigos} 4^{\circ}$ a $7^{\circ}$.

${ }^{181} \mathrm{LDB}, \operatorname{artigos} 8^{\circ}$ a 20 .

${ }^{182}$ Cf. 1.3.1.1.

${ }^{183}$ Cf. 2.3.1.

${ }^{184}$ CF. 1.3.1.2
} 


\subsubsection{Sistemas de ensino estabelecidos pela LDB}

Um aspecto importante da LDB a ser estudado no âmbito do presente trabalho é a organização da educação nacional, com o tratamento legal dado às competências federativas estabelecidas na Constituição, por meio da organização dos sistemas de ensino (federal, estadual e municipal), com a previsão da necessária colaboração entre eles. ${ }^{185}$ Para tanto, cabe à União a coordenação da política nacional de educação, articulando os diferentes níveis e sistemas e exercendo função normativa, redistributiva e supletiva em relação às demais instâncias educacionais. José Joaquim Gomes Canotilho apresenta a seguinte definição de sistema:

\footnotetext{
“ De forma deliberadamente abstracta e independente de qualquer "teoria sistémica" particular (ex: Easton, Luhmann) poderemos caracterizar um sistema como um conjunto de elementos em interacção, organizado em totalidade, que reage às interacções de tal forma que, quer ao nível dos elementos constitutivos quer ao nível do conjunto, aparecem fenómenos e qualidades novas não reconduzíveis aos elementos isolados ou à sua simples soma."186
}

Nesse sentido, tanto podem ser caracterizados como sistema a organização nacional da educação, envolvendo todos os níveis, quanto o campo de organização de cada ente da Federação na matéria. Por essa visão, os sistemas federal, estadual e municipal de ensino devem ser considerados subsistemas do sistema educacional nacional. Portanto, a configuração da organização do sistema nacional de educação no Brasil se apresenta como exemplo de federalismo cooperativo, ${ }^{187}$ compreendendo os sistemas educacionais de cada ente da Federação, que devem articular políticas públicas educacionais para atingir os objetivos comuns traçados no Plano Nacional de Educação. ${ }^{188}$

Pela LDB, compete à União: (a) elaborar o Plano Nacional de Educação, em colaboração com os Estados, o Distrito Federal e os Municípios; (b) organizar, manter e desenvolver os órgãos e instituições oficiais do sistema federal de ensino e o dos Territórios; (c) prestar assistência técnica e financeira aos Estados, ao Distrito Federal e aos Municípios para o desenvolvimento de seus sistemas de ensino e o atendimento prioritário à escolaridade obrigatória, exercendo sua função redistributiva e supletiva; (d)

\footnotetext{
${ }^{185}$ LDB, artigo $8^{\circ}$, caput.

${ }^{186}$ José Joaquim Gomes Canotilho, Direito constitucional, 6. ed., Coimbra: Almedina, 1993, p. 45.

${ }^{187}$ Segundo Gilberto Bercovici, no federalismo cooperativo, cada ente federado não pode atuar isoladamente, mas todos devem exercer suas competências conjuntamente com os demais, com a existência de um interesse comum (cf. Gilberto Bercovici, Desigualdades regionais, Estado e Constituição, São Paulo: Max Limonad, 2003, pp. 152-153).

${ }^{188}$ Cf. 1.3 .2 e 2.4 .
} 
estabelecer, em colaboração com os Estados, o Distrito Federal e os Municípios, competências e diretrizes para a educação infantil, o ensino fundamental e o ensino médio, que nortearão os currículos e seus conteúdos mínimos, de modo a assegurar formação básica comum; (e) coletar, analisar e disseminar informações sobre a educação; (f) assegurar processo nacional de avaliação do rendimento escolar no ensino fundamental, médio e superior, em colaboração com os sistemas de ensino, objetivando a definição de prioridades e a melhoria da qualidade do ensino; (g) baixar normas gerais sobre cursos de graduação e pós-graduação; (h) assegurar processo nacional de avaliação das instituições de educação superior, com a cooperação dos sistemas que tiverem responsabilidade sobre este nível de ensino; e (i) autorizar, reconhecer, credenciar, supervisionar e avaliar, respectivamente, os cursos das instituições de educação superior e os estabelecimentos do seu sistema de ensino. ${ }^{189}$ Além disso, a União deve em sua estrutura um Conselho Nacional de Educação, ${ }^{190}$ com funções normativas e de supervisão e atividade permanente. ${ }^{191}$ A LDB reforça, portanto, a competência coordenadora da União em matéria de política nacional de educação, prevista em diversos dispositivos da Constituição. ${ }^{192}$

Como área de atuação da competência da União, a LDB estabelece que o sistema federal de ensino compreende: (a) as instituições de ensino mantidas pela União; (b) as instituições de educação superior criadas e mantidas pela iniciativa privada; (c) os órgãos federais de educação. ${ }^{193}$

Aos Estados, segundo a LDB, compete: (a) organizar, manter e desenvolver os órgãos e instituições oficiais dos seus sistemas de ensino; (b) definir, com os Municípios, formas de colaboração na oferta do ensino fundamental, as quais devem assegurar a distribuição proporcional das responsabilidades, de acordo com a população a ser atendida e os recursos financeiros disponíveis em cada uma dessas esferas do Poder Público; (c) elaborar e executar políticas e planos educacionais, em consonância com as diretrizes e planos nacionais de educação, integrando e coordenando as suas ações e as dos seus Municípios; (d) autorizar, reconhecer, credenciar, supervisionar e avaliar, respectivamente, os cursos das instituições de educação superior e os estabelecimentos do seu sistema de

\footnotetext{
${ }^{189} \mathrm{LDB}$, artigo $9^{\circ}$.

${ }^{190}$ A competência do Conselho Nacional de Educação, no que se refere à regulação da educação superior, será abordada em subcapítulo próprio (cf. 5.4).

${ }^{191} \mathrm{LDB}$, artigo $9^{\circ}, \S 1^{\circ}$.

${ }^{192}$ Cf. Nina Beatriz Stocco Ranieri, "Os Estados e o direito à educação: comentários acerca da jurisprudência do Supremo Tribunal Federal", in Nina Beatriz Stocco Ranieri (coord.), Direito à educação: aspectos constitucionais, São Paulo: EDUSP, 2009, p. 42.

${ }^{193} \mathrm{LDB}$, artigo 16.
} 
ensino; (e) baixar normas complementares para o seu sistema de ensino; (f) assegurar o ensino fundamental e oferecer, com prioridade, o ensino médio a todos que o demandarem; ${ }^{194}$ (g) assumir o transporte escolar dos alunos da rede estadual. ${ }^{195}$

Conforme prescreve a LDB, ${ }^{196}$ ao Distrito Federal aplicam-se as competências referentes aos Estados e aos Municípios, conforme previsão constitucional. ${ }^{197}$ Por essa razão, esse diploma legal estabelece o sistema de ensino dos estados - e do Distrito Federal - para fins de exercício de suas competências, compreendendo: (a) as instituições de ensino mantidas, respectivamente, pelo Poder Público estadual e pelo Distrito Federal; (b) as instituições de educação superior mantidas pelo Poder Público municipal; (c) as instituições de ensino fundamental e médio criadas e mantidas pela iniciativa privada; (d) os órgãos de educação estaduais e do Distrito Federal, respectivamente. ${ }^{198}$ Ressalte-se que, como decorrência do acúmulo de competências estaduais e municipais, no Distrito Federal, as instituições de educação infantil, criadas e mantidas pela iniciativa privada, integram seu sistema de ensino. ${ }^{199}$

Os Municípios têm as seguintes competências, segundo a LDB: (a) organizar, manter e desenvolver os órgãos e instituições oficiais dos seus sistemas de ensino, integrando-os às políticas e planos educacionais da União e dos Estados; (b) exercer ação redistributiva em relação às suas escolas; (c) baixar normas complementares para o seu sistema de ensino; (d) autorizar, credenciar e supervisionar os estabelecimentos do seu sistema de ensino; (e) oferecer a educação infantil em creches e pré-escolas, e, com prioridade, o ensino fundamental, permitida a atuação em outros níveis de ensino somente quando estiverem atendidas plenamente as necessidades de sua área de competência e com recursos acima dos percentuais mínimos vinculados pela Constituição Federal à manutenção e desenvolvimento do ensino; e (f) assumir o transporte escolar dos alunos da rede municipal. ${ }^{200}$

Como área de atuação da competência dos Municípios, a LDB estabelece que o sistema municipal de ensino compreende: (a) as instituições do ensino fundamental, médio

\footnotetext{
${ }^{194}$ Dispositivo com redação dada pela Lei n ${ }^{\circ} 12.061$, de 2009.

${ }^{195} \mathrm{LDB}$, artigo $9^{\circ}, \S 1^{\circ}$.

${ }^{196}$ LDB, artigo 10, parágrafo único.

${ }^{197}$ Constituição da República Federativa do Brasil, artigo 32, $\S 1^{\circ}$.

${ }^{198}$ LDB, artigo 17.

${ }^{199}$ LDB, artigo 17, parágrafo único.

${ }^{200}$ LDB, artigo 11.
} 
e de educação infantil mantidas pelo Poder Público municipal; (b) os órgãos municipais de educação. $^{201}$

Nota-se que, para fins de estabelecimento dos sistemas de ensino, a LDB leva em consideração o conceito de mantença, ou seja, integram o sistema de cada unidade federativa as instituições por ela mantidas.

No que se refere à educação superior, portanto, consagrou-se que a regulação compete à União, no que se refere a suas instituições, bem como para as instituições criadas e mantidas pela iniciativa privada. No entanto, apesar da clareza das disposições constitucionais e legais, restavam dúvidas acerca do assunto.

Uma controvérsia a esse respeito existia por conta do disposto no artigo 82, § $1^{\circ}$, II, do Ato das Disposições Constitucionais Transitórias da Constituição do Estado de Minas Gerais, que previa a possibilidade de existência de instituições de educação superior criadas pelo Estado, mas mantidas pela iniciativa privada e submetidas à atividade regulatória estadual. ${ }^{202}$ Essa questão foi submetida ao Supremo Tribunal Federal, por meio da Ação Direta de Inconstitucionalidade no 2501, que julgou inconstitucional o dispositivo constitucional estadual mencionado, por meio de acórdão relatado pelo Ministro Joaquim Barbosa, que, de forma tecnicamente correta, adotou o conceito de mantença para definir a o sistema de ensino:

“3. O alcance da expressão "supervisão pedagógica", contida no inciso II do art. 82 do ADCT da Constituição Estadual de Minas Gerais, vai além do mero controle do conteúdo acadêmico dos cursos das instituições superiores privadas mineiras. Na verdade, a aplicação do dispositivo interfere no próprio reconhecimento e credenciamento de cursos superiores de universidades que são, atualmente, em sua integralidade privadas, pois extinto o vínculo com o Estado de Minas Gerais.

\footnotetext{
${ }^{201}$ LDB, artigo 18.

${ }^{202}$ Constituição do Estado de Minas Gerais, Ato das Disposições Constitucionais Transitórias, artigo 82:

“Art. 82 - Ficam mantidas as atuais instituições de ensino superior integrantes da Administração Pública Estadual.

$\S 1^{\circ}$ - As fundações educacionais de ensino superior instituídas pelo Estado ou com sua participação poderão manifestar-se no prazo de cento e oitenta dias contados da promulgação da Constituição por uma das seguintes opções:

I - absorção, como unidades, pela Universidade do Estado de Minas Gerais, na forma prevista no $\S 1^{\circ}$ do artigo anterior;

II - submissão à política educacional do Estado, mesmo que venham, mediante alteração dos seus estatutos, a extinguir seus vínculos com o poder público estadual, permanecendo sob a supervisão pedagógica do Conselho Estadual de Educação e obrigando-se, na forma da lei, a fornecer bolsas de estudos para os alunos carentes."
} 
4. O simples fato de a instituição de ensino superior ser mantida ou administrada por pessoas físicas ou jurídicas de direito privado basta à sua caracterização como instituição de ensino privada, e, por conseguinte, sujeita ao Sistema Federal de Ensino.

5. Portanto, as instituições de ensino superior originalmente criadas pelo estado de Minas Gerais, mas dele desvinculadas após a Constituição estadual de 1989, e sendo agora mantidas pela iniciativa privada, não pertencem ao Sistema Estadual de Educação e, consequentemente, não estão subordinadas ao Conselho Estadual de Educação, em especial no que tange à criação, ao credenciamento e descredenciamento, e à autorização para o funcionamento de cursos.

6. Invade a competência da União para legislar sobre diretrizes e bases da educação a norma estadual que, ainda que de forma indireta, subtrai do Ministério da Educação a competência para autorizar, reconhecer e credenciar cursos em instituições superiores privadas. 7. Inconstitucionalidade formal do art. 82, § $1^{\circ}$, II da Constituição do Estado de Minas Gerais que se reconhece por invasão de competência da União para legislar sobre diretrizes e bases da educação (art. 22, XXIV da CF/88). Inconstitucionalidade por arrastamento dos $\S 4^{\circ}$, $\S 5^{\circ}$ e $\S 6^{\circ}$ do mesmo art. 82, inseridos pela Emenda Constitucional Estadual 70/2005.

8. A autorização, o credenciamento e o reconhecimento dos cursos superiores de instituições privadas são regulados pela lei federal 9.394/1996, Lei de Diretrizes e Bases da Educação. Portanto, a presente decisão não abrange as instituições de ensino superior estaduais, criadas e mantidas pelo Estado de Minas Gerais - art. 10, IV c/c art. 17, I e II da lei 9.394/1996.”

No entanto, dado o caráter de excepcional interesse coletivo, o acórdão em questão atribuiu a modulação dos efeitos da declaração de inconstitucionalidade, conferindo ao Ministério da Educação o dever de regularizar a situação das instituições de educação superior que, equivocadamente, pertenciam ao sistema de ensino estadual mineiro:

"9. Tendo em vista o excepcional interesse social, consistente no fato de que milhares de estudantes freqüentaram e freqüentam cursos oferecidos pelas instituições superiores mantidas pela iniciativa privada no Estado de Minas Gerais, é deferida a modulação dos efeitos da decisão (art. 27 da lei 9.868/1999), a fim de que sejam considerados válidos os atos (diplomas, certificados, certidões etc.) praticados pelas instituições superiores de ensino atingidas por essa decisão, até a presente data, sem prejuízo do ulterior exercício, pelo Ministério da Educação, de suas atribuições legais em relação a essas instituições superiores."

A fim de dar cumprimento à decisão do Supremo Tribunal Federal, para regularizar a situação das instituições mineiras, bem como de instituições privadas que também estivessem, de forma errônea submetida a sistemas de ensino estaduais, o Ministério da Educação, por meio da Secretaria de Regulação e Supervisão da Educação 
Superior, publicou o Edital SERES/MEC n 01, de 09 de agosto de 2011, que instituiu regras para "migração de sistemas" de instituições de educação superior privadas.

Esse Edital regulamentou os procedimentos pelos quais as instituições de educação superior preponderantemente mantidas e/ou geridas pela iniciativa privada, que se encontravam submetidas aos sistemas estaduais de ensino, seriam submetidas ao sistema regulatório federal. Para tanto, foi estabelecido um prazo para que tais instituições solicitassem, por meio do sistema e-MEC, ${ }^{203}$ a abertura de procedimento administrativo para a emissão dos regulares atos autorizativos (credenciamento, recredenciamento, autorização de curso, reconhecimento de curso e renovação de reconhecimento de curso).

Tendo em vista o fato de nem todas as instituições que se encontravam nessa condição terem realizado a solicitação de "migração de sistema", no ano seguinte, foi publicado novo edital disciplinando esse procedimento - o Edital SERES/MEC ${ }^{\circ} 1$, de 14 de agosto de 2012.

\subsubsection{Níveis e modalidades de educação estabelecidos na LDB}

O presente subcapítulo busca apontar uma visão geral e sucinta sobre os níveis e modalidades educacionais, importante para localizar a posição do ensino superior - foco do presente trabalho, que será estudado com maior profundidade em subcapítulo próprio ${ }^{204}$ - no todo da educação.

A LDB estabelece como dois níveis escolares principais, que se desdobram em outros secundários: (a) a educação básica, formada pela educação infantil, ensino fundamental e ensino médio; e (b) a educação superior. ${ }^{205}$

Conforme previsão da LDB, o ensino médio poderá ser oferecido da forma tradicional ou em caráter técnico-profissional. De acordo com diversos dispositivos previstos na LDB, a educação superior compreende os seguintes cursos ou programas: curso sequencial por campo de saber; de extensão; de graduação (compreendendo bacharelado, licenciatura e tecnológico); de pós-graduação (compreendendo programas de mestrado, doutorado, especialização e aperfeiçoamento).

\footnotetext{
${ }^{203}$ Cf. 5.3 .

${ }^{204}$ Cf. Capítulo 4.

${ }^{205}$ LDB, artigo 21.
} 
Dessa maneira, em linhas gerais, o sistema educacional brasileiro compreende os seguintes níveis educacionais:

a) educação básica

$$
\begin{aligned}
& \text { a.1) educação infantil } \\
& \text { a.2 ensino fundamental } \\
& \text { a.3) ensino médio }
\end{aligned}
$$$$
\text { b.1) curso sequencial por campo de }
$$$$
\text { saber }
$$$$
\text { b.2) extensão }
$$$$
\text { b.3) graduação }
$$

b) educação superior

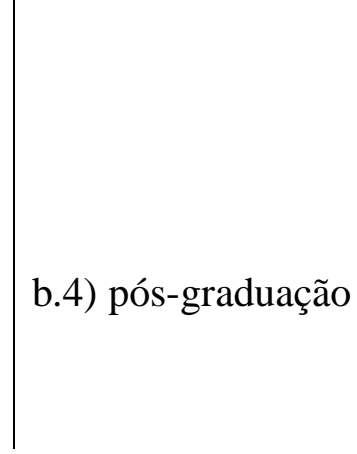

$$
\begin{aligned}
& \text { a.3.1) tradicional } \\
& \text { a.3.2) técnico-profissional }
\end{aligned}
$$

\begin{tabular}{l|l|l} 
b) educação superior & $\begin{array}{l}\text { b.1) curso sequencial por campo de } \\
\text { saber } \\
\text { b.2) extensão }\end{array}$ & $\begin{array}{l}\text { b.3.1) bacharelado } \\
\text { b.3) graduação }\end{array}$ \\
& b.3.3) licenciatura \\
b.4) pós-graduação & b.4.1) aperfeiçoamento \\
& b.4.2) especialização \\
& b.4.3) mestrado \\
& b.4.4) doutorado
\end{tabular}

O presente trabalho, com base na classificação apresentada, tem como objeto de análise os cursos superiores de graduação. A disciplina jurídica da educação superior, nesse nível, será estudada de forma mais profunda e específica em capítulo próprio. ${ }^{206}$

\subsubsection{Financiamento público de instituições educacionais privadas}

A Constituição estabelece que os recursos públicos são destinados às escolas públicas, podendo ser dirigidos a escolas comunitárias, confessionais ou filantrópicas, definidas em lei, que comprovem finalidade não-lucrativa e que apliquem seus excedentes financeiros em educação, bem como que assegurem a destinação de seu patrimônio a outra escola comunitária, filantrópica ou confessional, ou ao Poder Público, no caso de 
encerramento de suas atividades. ${ }^{207}$ A LDB repetiu o dispositivo constitucional, em seu artigo 77.

Essas disposições que tratam da destinação de recursos públicos a escolas confessionais, comunitárias ou filantrópicas tem caráter de fomento, e devem ser compreendidas em conjugação com a disposição constitucional, contida no artigo 205, que incentiva a colaboração da sociedade na educação, bem como com a permissão expressa de seu oferecimento pela iniciativa privada, desde que observadas as normas gerais e a existência de autorização e avaliação pelo Poder Público, nos termos do artigo $209 .{ }^{208}$

\subsubsection{Plano Nacional de Educação}

Constituição determina que o estabelecimento por lei o plano nacional de educação, de duração decenal, com o objetivo de articular o sistema nacional de educação em regime de colaboração e definir diretrizes, objetivos, metas e estratégias de implementação para assegurar a manutenção e desenvolvimento do ensino em seus diversos níveis, etapas e modalidades por meio de ações integradas dos poderes públicos das diferentes esferas federativas. ${ }^{209}$

Para dar cumprimento ao mandamento constitucional, foi promulgada a Lei $\mathrm{n}^{\mathrm{o}}$ 10.172/2001, que aprovou o Plano Nacional de Educação, para o período 2001-2010, que, em relação à educação superior, apresentou metas ambiciosas: prover, até o final da década, a oferta de educação superior para, pelo menos, 30\% da faixa etária de 18 a 24 anos, ${ }^{210}$ estabelecer uma política de expansão que diminua as desigualdades de oferta existentes entre as diferentes regiões do País $;{ }^{211}$ institucionalizar um amplo e diversificado sistema de avaliação interna e externa que englobe os setores público e privado, e promova a melhoria da qualidade do ensino, da pesquisa, da extensão e da gestão acadêmica; ${ }^{212}$ estabelecer sistema de recredenciamento periódico das instituições e reconhecimento periódico dos cursos superiores, apoiado no sistema nacional de avaliação. ${ }^{213}$

\footnotetext{
${ }^{207}$ Constituição Federal, artigo 213, caput.

${ }^{208}$ Cf. Nina Beatriz Stocco Ranieri, "Os Estados e o direito à educação", p. 44.

${ }^{209}$ Constituição da República Federativa do Brasil, artigo 214.

${ }^{210}$ Plano Nacional de Educação (2001-2010), Educação Superior, Meta 1.

${ }^{211}$ Plano Nacional de Educação (2001-2010), Educação Superior, Meta 3.

212 Plano Nacional de Educação (2001-2010), Educação Superior, Meta 6.

${ }^{213}$ Plano Nacional de Educação (2001-2010), Educação Superior, Meta 9.
} 
É importante, no entanto, ressalvar que a disposição do PNE que estabeleceu a meta de matrículas na educação superior - e não foi cumprida - prescrevia um substancial incremento dos gastos público com educação - atingindo o montante de 7\% do Produto Interno Bruto - a serem ampliados, anualmente, à razão de $0,5 \%$ do PIB, nos quatro primeiros anos e de $0,6 \%$ no quinto ano. Contudo, essa meta do plano foi vetada pelo Presidente da República, impedindo que a ampliação das vagas pusesse ser realizada fundamentalmente pelo Poder Público, passando a expansão planejada a depender quase que exclusivamente da expansão do setor privado. ${ }^{214}$

Encontra-se em tramitação o projeto de lei que visa à aprovação do Plano Nacional de Educação para o decênio 2011-2020. A análise dos dispositivos relativos à educação superior será realizada em subcapítulo próprio. ${ }^{215}$

${ }^{214}$ Cf. Eliezer Pacheco / Dilvo I. Ristoff, Educação superior: democratizando o acesso. Brasília: INEP, 2004, p. 8. ${ }^{215}$ Cf. 2.4 . 


\section{Capítulo 2 DIREITO EDUCACIONAL SUPERIOR}

\subsection{Educação Superior no Brasil: evolução histórica de seu tratamento jurídico}

A evolução histórica da educação superior no Brasil apresentou-se de maneira tardia, não apenas em relação à Europa, mas também se comparada à dos países da América de colonização espanhola. A diferença existente, nesse aspecto, entre as colonizações portuguesa e espanhola é reflexo do modelo centralizado de Portugal, em contraposição à descentralização espanhola nas Américas, que, além de organizar-se em vice-reinados, reproduziu muitas instituições em suas colônias, dentre as quais, as universidades, tendo sido a primeira delas criada em $1538 .{ }^{216}$

No momento da independência, a América espanhola contava com dezenove universidades, ao passo que o Brasil "só contou, no período colonial, com um arremedo de universidade na Bahia", ${ }^{217}$ criado em 1808, quando da mudança da sede da Coroa Portuguesa ao Brasil. Dessa maneira, desde sua gênese, a educação superior brasileira apresenta como fator importante para sua compreensão o papel centralizador do Estado, que também detinha o monopólio da formação de determinadas profissões, fator que contribuiu para o desenvolvimento da educação superior pautado fundamentalmente na formação profissional.

Desde o início do século XIX, o desenvolvimento do ensino superior se organizou com base em estabelecimentos isolados, ${ }^{218}$ constituídos por escolas profissionais de direito, de medicina e de artes militares e de engenharia. ${ }^{219}$ As universidades seriam criadas apenas no século XX. Os números demonstram quão insipiente era o sistema de educação superior brasileiro no final do século XIX: quando da proclamação da República, havia no país apenas cinco faculdades, sendo duas de Direito (São Paulo e Pernambuco), duas de Medicina (Bahia e Rio de Janeiro, e uma de Engenharia (Rio de Janeiro), com um total de 2.300 estudantes matriculados. ${ }^{220}$

\footnotetext{
${ }^{216}$ Cf. Gladys Beatriz Barreyro, Mapa do ensino superior privado, Brasília: INEP, 2008, p. 15.

${ }^{217}$ Darcy Ribeiro, A universidade necessária, 5. ed., São Paulo, Paz e Terra, 1991, p. 88.

${ }^{218}$ Cf. Gladys Beatriz Barreyro, Mapa do ensino superior privado, p. 15.

${ }^{219}$ Anísio Teixeira, A universidade de ontem e de hoje, p. 70.

${ }^{220}$ Cf. Darcy Ribeiro, A universidade necessária, p. 90.
} 
Após a proclamação da República, acompanhando a tendência de descentralização política por conta da adoção do modelo federativo de Estado, a educação superior foi, em parte, descentralizada em favor dos Estados, com a permissão de criação de instituições particulares e o reconhecimento nacional de tais diplomas, desde que atendidos os requisitos curriculares dos cursos federais. ${ }^{221}$ A partir da Constituição de 1891 é que se pode falar de ensino superior privado no Brasil com o surgimento das primeiras instituições particulares, geralmente de confissão católica ou criadas por elites locais. ${ }^{222}$

Após uma fase de tentativas locais de criação de universidades, que tiveram duração passageira, no Paraná, no Amazonas e em São Paulo, a União foi autorizada, em 1915, a criar uma universidade no Rio de Janeiro, por meio da reunião de escolas isoladas. No entanto, isso só se concretizou em 1920, com a criação da Universidade do Rio de Janeiro, a primeira do país. ${ }^{223}$. Essa técnica de criação de universidades por meio de aglutinação gerou um "mero conglomerado de escolas que continuavam a ser tão isoladas quanto antes". ${ }^{224}$ Anísio Teixeira denomina esse fenômeno de "federação de escolas profissionais", 225 apontando que, nessa época: "tivemos copiosa retórica sobre universidade, mas a estrutura não mudou. Continuamos a ter uma série de escolas profissionais frouxamente coordenadas por uma reitoria mais simbólica do real", 226

A partir de então, as instituições universitárias seriam criadas, predominantemente, de forma nacionalizada, integrada ao serviço público e subordinada ao Estado, uma vez que criada em benefício da estabilidade deste. Esse modelo de instituição ficou conhecido como universidade napoleônica, e foi adotado por muitos países de tradição administrativa francesa, dentre os quais o Brasil. ${ }^{227}$ Esse modelo de organização se caracterizava por ser um conglomerado de instituições autárquicas ${ }^{228}$ e foi o predominante na formação das universidades brasileiras.

A educação superior volta a ter o seu rumo condicionado aos fatores condicionantes da política nacional a partir de 1930, com o retorno a um maior grau de

${ }^{221}$ Cf. Nina Beatriz Stocco Ranieri, Educação Superior, Direito e Estado: na Lei de Diretrizes e Bases (Lei $n^{o}$ 9.394/96), São Paulo: Editora da Universidade de São Paulo, Fapesp, 2000, p. 45.

${ }^{222}$ Cf. Gladys Beatriz Barreyro, Mapa do ensino superior privado, p. 15.

${ }^{223}$ Luiz Antônio Cunha, A universidade temporã, pp. 177-190.

${ }^{224}$ Luiz Antônio Cunha, A universidade temporã, p. 194.

${ }^{225}$ Anísio Teixeira, A universidade de ontem e de hoje, p. 70.

${ }^{226}$ Anísio Teixeira, A universidade de ontem e de hoje, p. 70.

${ }^{227}$ Cf. Nina Beatriz Stocco Ranieri, Educação Superior, Direito e Estado, p. 41.

${ }^{228}$ Cf. Darcy Ribeiro, A universidade necessária, p. 105. 
centralização, consubstanciado, inicialmente, pela criação do Ministério da Educação e Saúde Pública em 1930. Ainda logo após a Revolução de 1930, o Decreto no 19.851, de 11 de abril de 1931, vigente até 1961, buscou organizar o ensino superior no Brasil, permitindo sua prestação por meio de instituições organizadas sob a forma de universidades ou de institutos isolados. As primeiras poderiam ser públicas (federais ou estaduais) ou privadas, mantidas por fundações ou associações. ${ }^{229}$

Na década de 1930, surgiram as Faculdades de Filosofia, Ciências e Letras, destinadas a ampliar o quadro universitário com os estudos dessas disciplinas, até então mantidos em nível secundário. No entanto, ao lado desse desenvolvimento houve, em maior grau, o desenvolvimento de escolas profissionais, como de engenharia, veterinária, agronomia, economia, contabilidade, enfermagem, belas-artes e serviço social, por exemplo. $^{230}$

O fenômeno da dispersão de cursos, mesmo no interior de uma mesma universidade, observado nessa época, por Anísio Teixeira, é, em grande medida persistente até os dias de hoje, em especial nas instituições públicas: "No Brasil temos uma série de oligarquias (congregações) isoladas e independentes, unidas por uma reivindicação comum em torno do orçamento, que é federal e feito e votado fora da universidade." ${ }^{231}$

Em 1948, pouco tempo após a promulgação da Constituição de 1946, foram iniciados a tramitação e os debates a respeito da Lei de Diretrizes e Bases da Educação, com a discussão do Projeto Mariani, sucedido pelo Substitutivo Lacerda. Ao longo das discussões, estabeleceu-se o confronto entre os privatistas, que defendiam a iniciativa particular na educação, e os defensores da educação pública gratuita e laica. ${ }^{232}$ Em 1961, foi promulgada a primeira Lei de Diretrizes e Bases da Educação (Lei n 4.024, de 20 de dezembro de 1961), que adotou uma solução conciliatória, ao permitir o desenvolvimento de atividades educacionais pela iniciativa privada, estabelecer a gratuidade do ensino e permitir que o Estado subvencionasse e financiasse instituições privadas. ${ }^{233}$

Além disso, a LDB de 1961 estabeleceu a competência de cada ente da federação em matéria educacional, determinando o campo de atuação de cada sistema de

\footnotetext{
${ }^{229}$ Cf. Gladys Beatriz Barreyro, Mapa do ensino superior privado, p. 16.

${ }^{230}$ Cf. Anísio Teixeira, A universidade de ontem e de hoje, pp. 71-72.

${ }^{231}$ Anísio Teixeira, A universidade de ontem e de hoje, p. 73.

${ }^{232}$ Cf. Pinto Ferreira, "Educação e Constituinte", p. 175.

${ }^{233}$ Cf. Pinto Ferreira, "Educação e Constituinte", p. 176.
} 
ensino. Em relação à educação superior, a Lei no 4.024/1961 trouxe para o plano legal a atividade regulatória do Poder Público, ao estabelecer a competência da União para reconhecer e inspecionar os estabelecimentos particulares de ensino superior. ${ }^{234}$

No que se refere à organização do ensino superior, as instituições poderiam ser agrupadas ou não em universidades, com a cooperação de institutos de pesquisa e centros de treinamento profissional. ${ }^{235}$ As universidades seriam constituídas pela reunião de cinco ou mais instituições isoladas, ${ }^{236}$ sob a forma de autarquias, fundações ou associações, ${ }^{237}$ formas essas também exigidas para a constituição dos estabelecimentos isolados. ${ }^{238}$

Alguns anos após a promulgação da Lei de Diretrizes e Bases da Educação de 1961, foi editada uma lei específica a respeito da educação superior: a Lei no 5.540 , de 28 de novembro de 1968, que ficou conhecida como a reforma universitária de $1968 .{ }^{239}$ Esse diploma legal, sem revogar expressamente a LDB de 1961, buscou organizar o sistema de educação superior, com a estabelecimento da indissociabilidade do ensino e da pesquisa, bem como com o estabelecimento da regra de que seu oferecimento seria proporcionado por universidades, admitida, excepcionalmente, a existência de estabelecimentos isolados, organizados como instituições de direito público ou privado. ${ }^{240}$ Era também estabelecido que as universidades e os estabelecimentos de ensino superior isolados públicos deveriam se constituir como autarquias de regime especial ou fundações de direito público, e as instituição particulares sob a forma de fundações ou associações. ${ }^{241}$ Segundo esta lei, a autorização $^{242}$ ou o reconhecimento ${ }^{243}$ de universidade ou estabelecimento isolado de

${ }^{234}$ Lei no 4.024/1961, artigo 14: “Art. 14. É da competência da União reconhecer e inspecionar os estabelecimentos particulares de ensino superior."

${ }^{235}$ Lei no 4.024/1961, artigo 67: "Art. 67. O ensino superior será ministrado em estabelecimentos, agrupados ou não em universidades, com a cooperação de institutos de pesquisa e centros de treinamento profissional."

${ }^{236}$ Lei no 4.024/1961, artigo 79: “Art. 79. As universidades constituem-se pela reunião, sob administração comum, de cinco ou mais estabelecimentos de ensino superior." É interessante mencionar que, no final desse dispositivo, foi vetada pelo Presidente da República a expressão "um dos quais deve ser uma faculdade de filosofia, ciências e letras".

${ }^{237}$ Lei $\mathrm{n}^{\circ}$ 4.024/1961, artigo 81: “Art. 81. As universidades serão constituídas sob a forma de autarquias, fundações ou associações. A inscrição do ato constitutivo no registro civil das pessoas jurídicas será precedido de autorização por decreto do governo federal ou estadual."

${ }^{238}$ Lei $n^{\circ}$ 4.024/1961, artigo 85: "Art. 85. Os estabelecimentos isolados serão constituídos sob a forma de autarquias, de fundações ou associações

${ }^{239}$ Essa lei ainda tem dispositivos vigentes, relativos à escolha de dirigentes de instituições educacionais.

${ }^{240}$ Lei $n^{\circ} 5.540 / 1968 / 1961$, artigo $2^{\circ}$ : “Art. $2^{\circ}$. O ensino superior, indissociável da pesquisa, será ministrado em universidades e, excepcionalmente, em estabelecimentos isolados, organizados como instituições de direito público ou privado.

${ }^{241}$ Lei $^{\circ}$ '5.540/1968/1961, artigo 4: “Art. 4 As universidades e os estabelecimentos de ensino superior isolados constituir-se-ão, quando oficiais, em autarquias de regime especial ou em fundações de direito público e, quando particulares, sob a forma de fundações ou associações."

${ }^{242}$ Expressão que à época era utilizada para o atual conceito de credenciamento. 
ensino superior era efetivado por decreto do Poder Executivo, após prévio parecer favorável do Conselho Federal de Educação. ${ }^{244}$

Pouco tempo depois, essa lei passou a ser aplicada de acordo com as disposições do Decreto-Lei $n^{\circ}$ 464, de 11 de fevereiro de 1969, que trouxe, para o plano legal, aspectos regulatórios, ao dispor que seria negada a autorização para o funcionamento de instituição, quando, embora satisfizesse os mínimos requisitos para sua criação, não correspondesse "às exigências do mercado de trabalho, em confronto com as necessidades do desenvolvimento nacional ou regional". ${ }^{245}$ Além disso, estabeleceu que o reconhecimento $^{246}$ das instituições deveria ser renovado periodicamente, de acordo com normas fixadas pelo Conselho Federal de Educação. ${ }^{247}$

Embora, como visto, a legislação buscasse a homogeneização do sistema, com a consolidação de um modelo baseado em instituições universitárias, com indissociabilidade entre ensino e pesquisa, o efeito produzido foi diferente, ${ }^{248}$ uma vez que a maior parte da grande expansão do ensino superior no país, entre a década de 1970 e 1990, se deu por meio de instituições privadas não universitárias. Tem-se, portanto, um quadro em que a atuação regulatória do poder público de caráter meramente cartorial, por meio da expedição de atos autorizativos de entrada ou manutenção de instituições no sistema educacional superior, que não teve preocupação com o estabelecimento de padrões de qualidade.

De fato, até o início da década de 1980, não havia grande interesse acadêmico e administrativo a respeito da avaliação da educação superior no Brasil. Em 1983, surgiu a primeira proposta de avaliação da educação superior no Brasil, o Programa de Avaliação da Reforma Universitária (PARU). Esse programa constituiu-se de questionários enviados a estudantes, dirigentes universitários e docentes destinados a analisar o impacto da Lei $\mathrm{n}^{\circ}$

\footnotetext{
${ }^{243}$ Expressão que à época era utilizada para o atual conceito de recredenciamento.

${ }^{244}$ Lei no 5.540/1968/1961, artigo 47: “Art. 47. A autorização ou o reconhecimento de universidade ou estabelecimento isolado de ensino superior será tornado efetivo, em qualquer caso, por decreto do Poder Executivo, após prévio parecer favorável do Conselho Federal de Educação, observado o disposto no artigo 44 desta Lei."

245 Decreto-lei no 464/1969, art. 2º, caput: “Art 2 Será negada autorização para funcionamento de universidade instituída diretamente ou estabelecimento isolado de ensino superior quando, satisfeitos embora os mínimos requisitos prefixados a sua criação não corresponda às exigências do mercado de trabalho, em confronto com as necessidades do desenvolvimento nacional ou regional."

${ }^{246}$ Expressão que à época era utilizada para o atual conceito de recredenciamento.

${ }^{247}$ Decreto-lei n ${ }^{\circ} 464 / 1969$, art. $2^{\circ}, \S 2^{\text {o: }}$ " Art. $2^{\circ}[\ldots]$

$\S 2^{\circ} \mathrm{O}$ reconhecimento das universidades e dos estabelecimentos isolados de ensino superior deverá ser renovado periòdicamente, de acôrdo com as normas fixadas pelo Conselho Federal de Educação.".

${ }^{248}$ Cf. Nina Beatriz Stocco Ranieri, Educação Superior, Direito e Estado, p. 53.
} 
5.540/1968 sobre o sistema de educação superior. ${ }^{249}$ Embora não tendo obtido resultados práticos, essa o PARU trouxe a discussão da avaliação da educação superior para o debate, em uma época que afloraram as discussões a respeito, por ocasião da Assembleia Nacional Constituinte, de 1987-1988.

Ao longo de todo esse período em que a educação foi livre à iniciativa privada, no entanto, foi mantido o entendimento que não admitia a existência de finalidade lucrativa no desempenho dessa atividade, ${ }^{250}$ expressamente estabelecido pela Resolução ${ }^{\circ} 29$, de 16 de junho de 1974, do Conselho Federal de Educação, que estabelecia, em seu artigo $2^{\circ}$, parágrafo único, que "as associações criadas para a manutenção de universidades não poderão ter fins lucrativos". ${ }^{251}$ Esse entendimento doutrinário também foi expresso no Parecer $n^{\circ} 780 / 1979$, do Conselho Federal de Educação, de lavra do Conselheiro Caio Tácito:

"Tornou-se tradicional, na jurisprudência do Conselho, a afirmativa de que a atividade educacional deve ser, necessariamente, uma atividade não lucrativa. É certamente razoável, a concepção de que a educação e a cultura não são artigos de comércio, em que a perseguição do lucro é a finalidade legítima e precípua do empresário, sujeito às limitações legais ou administrativas cabíveis. Todavia, o conceito não se pode extremar a rigores do absolutismo, a ponto de tornar cada empreendimento de ensino superior um complexo de benemerência e liberalidade, senão mesmo de prodigalidade. Temos para nós que o assunto, em todos os seus graus, é um serviço de utilidade pública, cuja exploração, dependente de autorização estatal, deve ficar sujeita, em sua prestação, a rigoroso controle de disciplina, que não lhe permitia ares de mercancia." 252

Dessa maneira, a educação superior no Brasil desenvolveu-se com a coexistência entre instituições públicas e privadas. Estas, no entanto, não poderiam ter finalidade lucrativa. A aceitação de regime lucrativo nas instituições privadas só se efetivou na década de 1990

${ }^{249}$ Cf. SINAES - Sistema Nacional de Avaliação da Educação Superior: da concepção à regulamentação, 4. ed., Brasília: INEP, 2007, p. 22.

${ }^{250}$ Cf. Carlos Roberto Jamil Cury, "O público e o privado na história da educação brasileira: concepções e práticas educativas", in José Claudinei Lombardi / Mara Regina M. Jacomeli / Tânia Mara T. da Silva (orgs.), O público e o privado na história da educação brasileira: concepções e práticas educativas, Campinas: Autores Associados, Histedbr, Unisal, 2005, pp. 20-21.

${ }^{251}$ Cf. Carlos Roberto Jamil Cury, "O público e o privado na história da educação brasileira", p. 20.

${ }^{252}$ Cf. Carlos Roberto Jamil Cury, "O público e o privado na história da educação brasileira”, p. 21. 


\subsection{Educação Superior na Constituição de 1988}

Em relação à educação superior, a Constituição estabelece, entre as garantias à efetivação do dever do Estado com a educação, o acesso aos níveis mais elevados do ensino, da pesquisa e da criação artística, segundo a capacidade de cada um. ${ }^{253}$ Esse dispositivo é fundamental para a discussão a respeito da adoção de ações afirmativas por parte do Estado em relação à educação superior.

A Constituição brasileira também acrescenta dois importantes dispositivos que tratam da educação superior: a liberdade de atuação da iniciativa privada no ensino com avaliação de qualidade pelo Poder Público (para a educação em todos os níveis), bem como a autonomia universitária.

\subsubsection{Liberdade à iniciativa privada e avaliação de qualidade pelo Poder Público}

A atividade educacional não poderá atingir suas finalidades se não gozar de um nível de qualidade satisfatório. Para tanto, dentre os princípios constitucionais setoriais da educação, encontra-se o da garantia do padrão de qualidade. Ao mesmo tempo, mantendo uma longa tradição, foi consagrado como igualmente como princípio da educação a coexistência de instituições públicas e privadas de ensino. Ambos os princípios mencionados encontram-se no artigo 206 da Constituição:

“Art. 206. O ensino será ministrado com base nos seguintes princípios:

$[\ldots]$

III - pluralismo de ideias e de concepções pedagógicas, e coexistência de instituições públicas e privadas de ensino;

$[\ldots]$

VII - garantia de padrão de qualidade.”

A fim de compatibilizar esses princípios, a Constituição estabeleceu o dispositivo fundamental para o desenvolvimento da presente tese:

“Art. 209. O ensino é livre à iniciativa privada, atendidas as seguintes condições:

I - cumprimento das normas gerais da educação nacional;

II - autorização e avaliação de qualidade pelo Poder Público.”

${ }^{253}$ Constituição da República Federativa do Brasil, artigo 208, V. 
Nota-se, assim, que pelo dispositivo transcrito: a atividade educacional é permitida à iniciativa privada, desde que esta: (a) observe a legislação nacional; (b) disponha de ato autorizativo por parte do Poder Público; e (c) se submeta à avaliação de qualidade pelo Poder Público. Dessa maneira, há uma relação de vinculação entre as duas últimas condições, o desempenho da atividade educacional pela iniciativa privada fica condicionado à avaliação de qualidade e autorização estatal. Esta relação deve ser regulamentada pelo legislador infraconstitucional, por meio de um marco regulatório (direito da educação) apto a instrumentalizar o Poder Público para desempenhar essa atividade, em busca da efetivação do direito à educação. Trata-se do dispositivo que fundamenta a atividade regulatória do Estado na educação superior.

Nesse sentido, a regime constitucional brasileiro parte da premissa da liberdade da iniciativa privada para atuação na área educacional. Comentando dispositivo similar existente na Constituição brasileira de 1946, Sampaio Dória assim afirmou: "O monopólio do ensino pelo Estado só se compreende nos regimes autocráticos, e, ainda assim, em termos. ${ }^{, 254}$ No entanto, a Constituição brasileira deixa clara sua preferência pelo ensino público, estabelecendo a participação da iniciativa privada, nesse campo, livre, mas secundária e condicionada. ${ }^{255}$

Apesar da longa tradição de não lucratividade na atividade educacional desenvolvida pela iniciativa privada, a Constituição de 1988 apresenta dispositivos que podem possibilitar a modificação desse entendimento: o artigo 213, que prevê que recursos públicos podem ser, sob determinadas condições destinados a escolas comunitárias, confessionais ou filantrópicas, que comprovem finalidade não-lucrativa; e o artigo 150, VI, “c”, que veda a instituição de impostos sobre patrimônio, renda ou serviços das instituições de educação sem fins lucrativos. Se a Constituição traz disposições aplicáveis a instituições educacionais privadas, desde que sejam sem fins lucrativos, é porque admite a possibilidade de existência de instituições com finalidade lucrativa. ${ }^{256}$

Dessa maneira, dentro de um contexto de Estado Social e Democrático de Direito, a Constituição preceituou que o ensino deveria ser ministrado com base no pluralismo de ideias e de concepções pedagógicas, garantindo, assim, a coexistência de

\footnotetext{
${ }^{254}$ Antônio de Sampaio Dória, Direito constitucional: comentários à Constituição de 1946, p. 769.

${ }^{255}$ José Afonso da Silva, Comentário contextual à Constituição, 7. ed., São Paulo: Malheiros, 2010, p. 810.

${ }^{256}$ Nesse sentido, Carlos Roberto Jamil Cury aponta que, "por oposição lógica, haveria a espécie das que poderiam ter finalidade lucrativa", cf. Carlos Roberto Jamil Cury, "O público e o privado na história da educação brasileira", p. 23).
} 
instituições públicas e privadas de ensino, ${ }^{257}$ no mesmo espírito de um dos pontos do texto aprovado em 2009 na Conferência Mundial sobre Ensino Superior - As Novas Dinâmicas do Ensino Superior e Pesquisas para a Mudança e o Desenvolvimento Social:

"10. A sociedade do conhecimento precisa de diversidade nos sistemas de educação superior com uma gama de instituições que tenha uma variedade de ordens e abranja tipos diferentes de alunos. Além de instituições públicas, o ensino superior privado que busca objetivos públicos desempenha um papel importante."

\subsubsection{Universidades, centros universitários e autonomia universitária}

A Constituição brasileira também estabelece a autonomia universitária, ao prescrever que as universidades gozam de autonomia didático-científica, administrativa e de gestão financeira e patrimonial, e que obedecerão ao princípio de indissociabilidade entre ensino, pesquisa e extensão. ${ }^{258}$ A LDB, em observância à Constituição, define as universidades como instituições pluridisciplinares de formação dos quadros profissionais de nível superior, de pesquisa, de extensão e de domínio e cultivo do saber humano, ${ }^{259}$ caracterizando-as por: (a) ter produção intelectual institucionalizada mediante o estudo sistemático dos temas e problemas mais relevantes, tanto do ponto de vista científico e cultural, quanto regional e nacional; (b) ter um terço do corpo docente, pelo menos, com titulação acadêmica de mestrado ou doutorado; (c) um terço do corpo docente em regime de tempo integral; sendo possível a criação de universidades especializadas por campo do saber. $^{260}$

Assim sendo, a LDB inova ao condicionar, de forma clara, o desenvolvimento de atividades de ensino, pesquisa e extensão, com a produção científica comprovada, como condição necessária para seu credenciamento de uma instituição como universidade. ${ }^{261}$ Além disso, estabelece padrões mínimos de exigência no que diz respeito à titulação e ao regime de trabalho do corpo docente.

As universidades cumprem, assim, um papel importante para a consecução dos objetivos da educação superior constitucionalmente estabelecidos, tendo em vista que, por

257 Vladmir Oliveira da Silveira / Irene Patrícia Nohara, "Supervisão do ensino superior de direito no contexto federativo e complexidades do controle da pós-graduação stricto sensu - tensões do discurso do desempenho em face do objetivo da democratização", Revista de Direito Educacional 5 (2012), p. 278.

${ }^{258}$ Constituição da República Federativa do Brasil, art. 207

${ }^{259}$ LDB, artigo 52, caput.

${ }^{260}$ LDB, artigo 52.

${ }^{261}$ Cf. Solange Alfinito, Educação superior no Brasil: análise do histórico recente (1994-2003), p. 11. 
meio de suas atividades de ensino, pesquisa e extensão, exercem papel fundamental no desenvolvimento das ciências, das letras e das artes, na formação de profissionais qualificados e na prestação de serviços à comunidade. ${ }^{262}$

Apesar da crítica que se faz às universidades, de suposta excessiva prioridade à pesquisa, desprestigiando seu papel de ensino de graduação, na realidade, a melhoria da qualidade do ensino se faz por meio de sua articulação com a pesquisa e extensão. Caso contrário, o ensino tende a se guiar por uma lógica meramente profissionalizante, alheia à necessidade não só da formação científica, mas também de uma densa e consistente formação política". ${ }^{263}$

Por essa razão, embora de acordo com a disposição constitucional apenas as universidades tenham a obrigação de realizar pesquisa e extensão institucionalizadas, dada sua importância para a educação superior, as normas de regulação da educação superior passaram a exigir, por meio de seus instrumentos de avaliação, a realização de atividades organizadas de pesquisa e extensão inclusive de instituições organizadas como faculdades, em níveis de exigência inferiores, no entanto, em relação às instituições universitárias.

Apesar de não haver previsão na LDB, no ano seguinte a sua promulgação, foi criada uma nova categoria de estabelecimentos de ensino superior, por meio do Decreto $\mathrm{n}^{\mathrm{o}}$ 2.306, de 19 de agosto de 1997: o centro universitário, para o qual era exigida excelência de ensino e, em contrapartida, conferidas algumas atribuições relativas à autonomia universitária. ${ }^{264}$ Atualmente, o mencionado decreto foi revogado e a disciplina a respeito dos centros universitários, e de sua autonomia, está no Decreto no 5.786 , de 24 de maio de 2006 , que estabelece critérios quantitativos em relação ao corpo docente. ${ }^{265}$

\footnotetext{
${ }^{262}$ Cf. Esther de Figueiredo Ferraz, Alternativas da educação, p. 141.

${ }^{263}$ Cf. Antônio Joaquim Severino, "Expansão do ensino superior: contextos, desafios, possibilidades", p. 258.

${ }^{264}$ Decreto no $2.306 / 1997$, artigo 12:

“Art. 12. São centros universitários as instituições de ensino superior pluricurriculares, abrangendo uma ou mais áreas do conhecimento, que se caracterizam pela excelência do ensino oferecido, comprovada pela qualificação do seu corpo docente e pelas condições de trabalho acadêmico oferecidas à comunidade escolar, nos termos das normas estabelecidas pelo Ministro de Estado da Educação e do Desporto para o seu credenciamento.

$\S 1^{\circ}$ Fica estendida aos centros universitários credenciados autonomia para criar, organizar e extinguir, em sua sede, cursos e programas de educação superior, assim como remanejar ou ampliar vagas nos cursos existentes.

$\S 2^{\circ}$ Os centros universitários poderão usufruir de outras atribuições da autonomia universitária, além da que se refere o parágrafo anterior, devidamente definidas no ato de seu credenciamento, nos termos do $\S 2^{\circ}$ do art. 54 da Lei n ${ }^{\circ} 9.394$, de 1996.".

${ }^{265}$ Decreto no $^{\circ} 5.786 / 2006$, artigo $1^{\text {o: }}$.
} 
Apesar do estabelecimento de exigências quantitativas relativas à titulação e regime de dedicação do corpo docente para as universidades e centros universitários, pela LDB e pelo Decreto $\mathrm{n}^{\circ} 5.786 / 2006$, respectivamente, em momento posterior, por meio de Resoluções, o Conselho Nacional de Educação estabeleceu critérios mais exigentes para o credenciamento e recredenciamento de universidades ${ }^{266}$ e centros universitários. ${ }^{267}$

Com a nova regulamentação, a os centros universitários são criados a partir de faculdades já credenciadas, com, no mínimo, seis anos de funcionamento e que tenham obtido conceito igual ou superior a quatro, na avaliação institucional externa, no ciclo avaliativo do Sistema Nacional de Avaliação da Educação Superior (SINAES) imediatamente anterior, ${ }^{268}$ e apresentando, ainda, as seguintes condições: (a) mínimo de $20 \%$ (vinte por cento) do corpo docente contratado em regime de tempo integral; (b) mínimo de $33 \%$ (trinta e três por cento) do corpo docente com titulação acadêmica de mestrado ou doutorado; (c) mínimo de 8 (oito) cursos de graduação reconhecidos e com conceito satisfatório obtido na avaliação realizada pelo Ministério da Educação; (d) plano de desenvolvimento institucional e proposta de estatuto compatíveis com a solicitação de transformação em Centro Universitário; (e) programa de extensão institucionalizado nas áreas do conhecimento abrangidas por seus cursos de graduação; (f) programa de iniciação científica com projeto orientado por professores doutores ou mestres, podendo também oferecer programas de iniciação profissional ou tecnológica e de iniciação à docência; $(\mathrm{g})$ plano de carreira e política de capacitação docente implantados; (h) biblioteca com integração efetiva na vida acadêmica da Instituição e que atenda às exigências dos cursos em funcionamento, com planos fundamentados de expansão física e de acervo; (i) não ter firmado, nos últimos 3 (três) anos, termo de saneamento de deficiências ou protocolo de compromisso com o Ministério da Educação, relativamente à própria Instituição ou qualquer de seus cursos; (j) não ter sofrido qualquer das penalidades relativa ao sistema de regulação da educação superior. ${ }^{269}$

\footnotetext{
"Art. $1^{\circ}$ Os centros universitários são instituições de ensino superior pluricurriculares, que se caracterizam pela excelência do ensino oferecido, pela qualificação do seu corpo docente e pelas condições de trabalho acadêmico oferecidas à comunidade escolar.

Parágrafo único. Classificam-se como centros universitários as instituições de ensino superior que atendam aos seguintes requisitos:

I - um quinto do corpo docente em regime de tempo integral; e

II - um terço do corpo docente, pelo menos, com titulação acadêmica de mestrado ou doutorado.".

${ }^{266}$ Por meio da Resolução CNE/CES n ${ }^{\circ}$ 3, de 14 de outubro de 2010.

${ }^{267}$ Por meio da Resolução CNE/CES no 1 , de 20 de janeiro de 2010.

${ }^{268}$ Resolução CNE/CES n ${ }^{\circ} 1$, de 20 de janeiro de 2010, artigo $2^{\circ}$.

${ }^{269}$ Resolução CNE/CES n ${ }^{\circ} 1$, de 20 de janeiro de 2010, artigo $3^{\circ}$.
} 
Dessa forma, apesar de ter mantido as exigências quantitativas contidas no Decreto $\mathrm{n}^{\mathrm{o}}$ 5.786/2006, a Resolução CNE/CES $\mathrm{n}^{\mathrm{o}}$ 1/2010 passou a exigir, para o credenciamento de centros universitários, importantes requisitos qualitativos, com a vinculação à avaliação institucional realizada no âmbito do SINAES, bem como a institucionalização da pesquisa e extensão e o estabelecimento de um número mínimo de cursos.

De maneira similar, para o credenciamento de universidades, a Resolução CNE/CES n 3, de 14 de outubro de 2010 apresentou as condições para o requerimento do credenciamento de uma instituição como universidade: (a) um terço do corpo docente, com titulação de mestrado ou doutorado; (b) um terço do corpo docente em regime de tempo integral; (c) Conceito Institucional (CI) igual ou superior a 4 (quatro) na última Avaliação Institucional Externa do SINAES; (d) Índice Geral de Cursos (IGC) igual ou superior a 4 (quatro) na última divulgação oficial do Instituto Nacional de Estudos e Pesquisas Anísio Teixeira (INEP); (e) oferta regular de, no mínimo, 60\% (sessenta por cento) dos cursos de graduação reconhecidos ou em processo de reconhecimento devidamente protocolado, no prazo regular; (f) oferta regular de, pelo menos, 4 (quatro) cursos de mestrado e 2 (dois) de doutorado, reconhecidos pelo Ministério da Educação (MEC); (g) compatibilidade do Plano de Desenvolvimento Institucional (PDI) e do Estatuto com a categoria de universidade; e (h) não ter sofrido, nos 5 (cinco) anos anteriores, penalidades administrativas do sistema de regulação da educação superior. ${ }^{270}$

Conforme visto, as exigências contidas na LDB relativas à titulação e dedicação do corpo docente foram mantidas, mas estabeleceram-se exigências relativas a indicadores de qualidade aferidos durante o processo de avaliação das instituições e cursos. Além disso, a exigência de um número mínimo de programas de mestrado e doutorado, além de dificultar o credenciamento de novas universidades, poderá comprometer a manutenção dessa condição por parte de universidades já existentes. Isso porque as atuais universidades deverão buscar o atendimento dessa exigência até 2016, por meio de uma regra de transição: poderão ser recredenciadas, em caráter excepcional, desde que ofertem regularmente, pelo menos, 3 (três) cursos de mestrado e 1 (um) de doutorado até o ano de 2013 , e de 4 (quatro) mestrados e 2 (dois) doutorados até o ano de $2016 .{ }^{271}$

\footnotetext{
${ }^{270}$ Resolução CNE/CES n ${ }^{\circ} 3$, de 14 de outubro de 2010, artigo $3^{\circ}$.

${ }^{271}$ Resolução CNE/CES n ${ }^{\circ} 3$, de 14 de outubro de 2010, artigo 11 .
} 
Esse aspecto tem grande relação com a atividade regulatória do Estado, pois a legislação estabelece critérios mínimos de exigência para o credenciamento de universidades, sendo permitido o estabelecimento progressivo de exigências superiores de qualidade. Há uma relação direta aqui entre políticas de regulação da educação superior relativa a cursos de graduação e de pós-graduação, desenvolvida pela Coordenação de Aperfeiçoamento de Pessoal de Nível Superior - CAPES: a exigência de um número mínimo de programas de mestrado e doutorado para o credenciamento de universidades poderá acarretar o número de programas nesse nível. O aumento da oferta de cursos de pós-graduação stricto sensu poderá permitir o aumento da exigência de professores com esse tipo de titulação nos cursos de graduação. ${ }^{272}$

Em linhas gerais, as exigências quantitativas e qualitativas relativas a universidades e centros universitários mostram-se pertinentes, tendo em vista que a existência de condições mínimas de qualificação do corpo docente e de regime de trabalho e a presença de indicadores de qualidade elevados são fundamentais para o desenvolvimento de atividades de pesquisa e extensão, características das instituições que gozam das prerrogativas de autonomia universitária. ${ }^{273}$

Apesar de ter a sua previsão constitucional discutida desde a Assembleia Geral Constituinte de $1823,{ }^{274}$ a autonomia universitária só foi estabelecida no plano constitucional pela Constituição de 1988, ganhando tratamento mais detalhado na LDB, que assegura às universidades, para seu exercício, as seguintes atribuições: (a) criar, organizar e extinguir, em sua sede, cursos e programas de educação superior previstos nesta Lei, obedecendo às normas gerais da União e, quando for o caso, do respectivo sistema de ensino; (b) fixar os currículos dos seus cursos e programas, observadas as diretrizes gerais pertinentes; (c) estabelecer planos, programas e projetos de pesquisa científica, produção artística e atividades de extensão; (d) fixar o número de vagas de acordo com a capacidade institucional e as exigências do seu meio; (e) elaborar e reformar os seus estatutos e regimentos em consonância com as normas gerais atinentes; (f) conferir graus, diplomas e outros títulos; (g) firmar contratos, acordos e convênios; (h) aprovar e executar planos, programas e projetos de investimentos referentes a obras, serviços e

\footnotetext{
${ }^{272} \mathrm{O}$ aumento da integração do sistema da regulação da educação superior no nível de pós-graduação stricto sensu - desenvolvido pela CAPES e já consolidado em padrões de qualidade reconhecidos internacionalmente - com o SINAES é uma tendência, que pode ser percebida com o fato de um membro da CAPES ter assento na Comissão Nacional de Avaliação da Educação Superior - CONAES (cf. 5.4.3).

${ }^{273}$ Cf. Solange Alfinito, Educação superior no Brasil: análise do histórico recente (1994-2003), p. 12.

${ }^{274}$ Edivaldo M. Boaventura, “A constitucionalização da autonomia universitária”, p. 299.
} 
aquisições em geral, bem como administrar rendimentos conforme dispositivos institucionais; (i) administrar os rendimentos e deles dispor na forma prevista no ato de constituição, nas leis e nos respectivos estatutos; (j) receber subvenções, doações, heranças, legados e cooperação financeira resultante de convênios com entidades públicas e privadas. ${ }^{275}$ As prerrogativas de autonomia dos centros universitários, que estão previstos em normas infraconstitucionais, são mais limitadas do que a das universidades.

Tendo em vista a atribuição dessas prerrogativas às universidades e centros universitários, evidentemente, a margem de regulação estatal é reduzido em relação às atividades educacionais desenvolvidas por essas instituições. Por outro lado, para que instituições possam vir a ser credenciadas como universidades ou centros universitários, deverão passar por um crivo regulatório mais forte.

A ideia de autonomia universitária, como poder das universidades de dirigir suas atividades e seus destinos, está ligada a suas remotas origens e tem-se mantido, ao longo de sua história, como uma exigência permanente que emana da própria natureza da instituição universitária: "a gênese da universidade medieval pode ser caracterizada como uma luta, por vezes dramática, para afirmar sua autonomia". ${ }^{276}$ Isso se deve ao fato de que as universidades europeias surgiram em momento histórico anterior aos Estados nacionais, e, por essa razão, com grande grau de autonomia, em uma época de fragmentação espacial do poder político. ${ }^{277}$

No entanto, no caso brasileiro, as universidades, em sua maioria, foram criadas pelo Estado tardiamente, com as prerrogativas de autonomia das entidades da administração indireta, ou pela iniciativa privada, após cumprir as exigências impostas pelo Estado. A diferença de contexto histórico entre o surgimento das universidades europeias e brasileiras apresenta problemas na aplicação da doutrina internacional a respeito de autonomia universitária. A peculiaridade do conceito de autonomia universitária na realidade brasileira é exposta por Nina Beatriz Stocco Ranieri:

“A rigor, a recepção da autonomia universitária pela Constituição Federal, exige a utilização de formas institucionais mais consentâneas à realidade jurídica que se encerra nas competências assim outorgadas às universidades estatais, realidade que as especializa no conjunto da administração pública e que lhes confere natureza particular: a de entes autônomos que,

\footnotetext{
${ }^{275}$ LDB, artigo 53.

${ }^{276}$ Cf. Edivaldo M. Boaventura, “A Constituição e a educação brasileira”, p. 35.

277 Sobre esse fenômeno, vide Nina Beatriz Stocco Ranieri, Autonomia universitária, São Paulo: EDUSP, 1994, pp. 35-48.
} 
embora sob a égide do Estado, exercem poder político derivado e instrumental em matéria didático-científica, administrativa e de gestão financeira e patrimonial." ${ }^{278}$

Um exemplo importante de restrição ao regime da autonomia universitária imposta pelo sistema regulatório da educação superior é a limitação à criação de cursos de graduação nas áreas direito, medicina, odontologia e psicologia, que ficam condicionadas à autorização prévia do MEC, mesmo para universidades e centros universitários. ${ }^{279} \mathrm{O}$ procedimento de autorização para esses cursos prevê a manifestação do Conselho Federal da Ordem dos Advogados do Brasil (para o curso de direito) ou do Conselho Nacional de Saúde (para os demais). Nesses casos, a autonomia é mitigada para concretizar outras disposições normativas.

O Sistema Único de Saúde - do qual o Conselho Nacional de Saúde faz parte tem a competência de "ordenar a formação de recursos humanos na área de saúde". ${ }^{280}$ Por essa razão, ao Conselho Nacional de Saúde ${ }^{281}$ - tem a competência de "articular-se com o Ministério da Educação quanto à criação de novos cursos de ensino superior na área de saúde, no que concerne à caracterização das necessidades sociais". ${ }^{282}$ Ao Conselho Federal da Ordem dos Advogados do Brasil compete "colaborar com o aperfeiçoamento dos cursos jurídicos, e opinar, previamente, ${ }^{283}$ nos pedidos apresentados aos órgãos competentes para criação, reconhecimento ou credenciamento desses cursos". 284

Esse é um exemplo do potencial de colisão entre o estabelecimento das prerrogativas de autonomia universitária e a consolidação de um sistema nacional de regulação da educação superior.

\subsection{Educação superior na Lei de Diretrizes e Bases da Educação}

Segundo a LDB a educação superior tem por finalidade: (a) estimular a criação cultural e o desenvolvimento do espírito científico e do pensamento reflexivo; (b) formar diplomados nas diferentes áreas de conhecimento, aptos para a inserção em setores

\footnotetext{
278 Nina Beatriz Stocco Ranieri, Autonomia universitária, p. 31.

${ }^{279}$ Decreto 5.839, de 11 de julho de 2006, artigo 28, § 2 .

${ }^{280}$ Constituição da República Federativa do Brasil, artigo 200, III.

281 A manifestação do Conselho Nacional de Saúde nos procedimentos regulatórios é disciplinada pela Resolução CNS nº 350, de 09 de junho de 2005.

${ }^{282}$ Decreto $^{\circ} 5.839 / 2006$, artigo $2^{\circ}$, VIII.

${ }^{283} \mathrm{O}$ procedimento de manifestação do Conselho Federal da Ordem dos Advogados do Brasil é disciplinado pela Instrução Normativa OAB n ${ }^{\text {o }} 1$, de 06 de dezembro de 2008.

${ }^{284}$ Lei no 8.906, de 4 de julho de 1994, artigo 54, XV.
} 
profissionais e para a participação no desenvolvimento da sociedade brasileira, e colaborar na sua formação contínua; (c) incentivar o trabalho de pesquisa e investigação científica, visando ao desenvolvimento da ciência e da tecnologia e da criação e difusão da cultura, e, desse modo, desenvolver o entendimento do homem e do meio em que vive; (d) promover a divulgação de conhecimentos culturais, científicos e técnicos que constituem patrimônio da humanidade e comunicar o saber através do ensino, de publicações ou de outras formas de comunicação; (e) suscitar o desejo permanente de aperfeiçoamento cultural e profissional e possibilitar a correspondente concretização, integrando os conhecimentos que vão sendo adquiridos numa estrutura intelectual sistematizadora do conhecimento de cada geração; (f) estimular o conhecimento dos problemas do mundo presente, em particular os nacionais e regionais, prestar serviços especializados à comunidade e estabelecer com esta uma relação de reciprocidade; $(\mathrm{g})$ promover a extensão, aberta à participação da população, visando à difusão das conquistas e benefícios resultantes da criação cultural e da pesquisa científica e tecnológica geradas na instituição. ${ }^{285}$

Nota-se que tais finalidades possuem estreita relação com os objetivos da República Federativa do Brasil, principalmente em relação à promoção do desenvolvimento socioeconômico do país e à diminuição das desigualdades sociais e regionais. Disso decorre a relevância do estudo jurídico da educação superior.

\subsubsection{Conceitos fundamentais relativos à educação superior}

A LDB apresenta os conceitos fundamentais a respeito da educação superior. No entanto, dado o seu caráter geral e abstrato, há uma série de conceitos relativos à atividade educacional que necessitaram de definição infralegal, uma vez que apresentavam ambiguidades, que se tornaram objeto de controvérsias. ${ }^{286}$ Por essa razão, a Portaria Normativa $\mathrm{n}^{\mathrm{o}} 40$, de 12 de dezembro de 2007, com as alterações trazidas pela Portaria Normativa $\mathrm{n}^{\mathrm{o}} 23$, de $1^{\circ}$ de dezembro de 2010, apresenta, em seu Anexo, um quadro de conceitos de referência para as bases de dados do Ministério da Educação sobre educação

\footnotetext{
${ }^{285}$ LDB, artigo 43.

${ }^{286}$ A esse respeito, ilustrativo é o debate a respeito do conceito de hora-aula. Apesar de seu conteúdo ser determinado em seu próprio termo, havia controvérsia a respeito da possibilidade da contabilização da "hora de 50 minutos", costumeiramente utilizada, como uma hora-aula, para fins de carga horária de integralização do curso. A Resolução CNE/CES n ${ }^{\circ}$, de 2 de julho de 2007, estabeleceu que "a definição quantitativa em minutos do que consiste a hora-aula é uma atribuição das Instituições de Educação Superior, desde que feita sem prejuízo ao cumprimento das respectivas cargas horárias totais dos cursos" (artigo $1^{\circ}, \S 2^{\circ}$ ), reafirmando a convenção universalmente aceita de que uma hora é equivalente a 60 minutos.
} 
superior, fundamentais para a compreensão do sistema regulatório da educação superior, complementando conceitos contidos na LDB. Alguns desses conceitos, por constarem em atos autorizativos, relatórios e instrumentos de avaliação, precisam se mostrar unívocos, a fim de não gerarem dúvidas a respeito de seu alcance.

\subsubsection{Conceitos relativos a instituições educacionais}

Um importante conceito a ser considerado na atividade regulatória da educação superior é o de mantença da instituição. Segundo a Portaria Normativa $n^{0}$ 40/2007, Anexo, itens 1.1 e 1.2, mantenedora é a pessoa jurídica que provê os recursos necessários ao funcionamento da instituição de ensino e a representa legalmente; e mantida é a instituição de ensino superior que realiza a oferta da educação superior ${ }^{287}$ Nesse sentido, a mantença da instituição constitui-se na relação entre mantenedora e mantida, no que se refere ao provimento de recursos necessários ao desenvolvimento das atividades educacionais. O critério de mantença é utilizado pela LDB para classificar as instituições educacionais quanto à sua categoria administrativa. Para tanto, inicialmente, distinguem-se duas categorias administrativas de instituições: (a) as públicas, assim entendidas as criadas ou incorporadas, mantidas e administradas pelo Poder Público; e (b) as privadas, assim entendidas as mantidas e administradas por pessoas físicas ou jurídicas de direito privado. $^{288}$

Com base no conceito de mantença, as instituições educacionais são classificadas de acordo com sua categoria administrativa. As instituições públicas podem ser federais, estaduais, distritais ou municipais, segundo o critério de mantença, e devem ter gratuidade de matrículas e mensalidades. ${ }^{289}$ No entanto, deve ser ressaltada a hipótese excepcional e transitória de exceção ao princípio da gratuidade do ensino em estabelecimentos oficiais, por meio de instituições educacionais especiais, criadas por lei estadual ou municipal, e existentes na data da promulgação desta Constituição, que não sejam total ou preponderantemente mantidas com recursos públicos. ${ }^{290}$

\footnotetext{
${ }^{287}$ Portaria Normativa $n^{\circ} 40 / 2007$, Anexo, itens 1.1 e 1.2 .

${ }^{288}$ LDB, artigo 19.

${ }^{289}$ Portaria Normativa no 40/2007, Anexo, itens 2.1.1, 2.1.2 e 2.1.3.

${ }^{290}$ Constituição da República Federativa do Brasil, artigo 242, caput.
} 
Em relação às instituições educacionais privadas, a LDB estabelece as seguintes categorias administrativas: ${ }^{291}$ (a) comunitárias, assim entendidas as que sejam instituídas por grupos de pessoas físicas ou por uma ou mais pessoas jurídicas, inclusive cooperativas educacionais, sem fins lucrativos, que incluam na sua entidade mantenedora representantes da comunidade; ${ }^{292}$ (b) confessionais, assim entendidas as que atendam aos requisitos exigidos para as instituições comunitárias, e ainda sejam instituídas por grupos de pessoas físicas ou por uma ou mais pessoas jurídicas que atendem a orientação confessional e ideologia específicas; (c) filantrópicas, que atendam aos requisitos estabelecidos em legislação própria; e (d) particulares em sentido estrito, de conceituação residual, pois são entendidas como aquelas instituídas e mantidas por uma ou mais pessoas físicas ou jurídicas de direito privado que não se configurem como comunitárias, confessionais ou filantrópicas.

A Portaria Normativa $n^{0}$ 40/2007 traz outra classificação em relação às entidades privadas, que tem por critério a finalidade lucrativa e a caracterização como beneficente. Por essa classificação, as instituições privadas podem ser: ${ }^{293}$ (a) com fins lucrativos, quando mantidas por ente privado, com fins lucrativos; (b) sem fins lucrativos não beneficentes, quando mantidas por ente privado, sem fins lucrativos (podendo ser confessional ou comunitária); e (c) beneficentes, quando mantidas por ente privado, sem fins lucrativos, detentora de Certificado de Assistência Social, nos termos de legislação própria.

Tendo em vista a possível confusão entre os conceitos de instituição particular e o de privada, expressões que, na linguagem comum, aparentam sinonímia, ${ }^{294}$ o presente trabalho adota conceitualmente o modelo trazido pela LDB. Dessa maneira, compreende-se como conceito de instituição privada aquele tomado em seu sentido amplo (incluindo comunitárias, confessionais, filantrópicas e particulares em sentido estrito), e como conceito de instituição particular aquele compreendido em sentido estrito (excluindo-se as comunitárias, confessionais e filantrópicas).

\footnotetext{
${ }^{291}$ LDB, artigo 20.

${ }^{292}$ Com definição dada pela Lei no 12.020 , de 2009.

${ }^{293}$ Portaria Normativa $n^{\circ}$ 40/2007, Anexo, itens 2.2.1, 2.2.2 e 2.2.3.

${ }^{294}$ De acordo com o Dicionário Houaiss Eletrônico, versão junho de 2009, a palavra "particular" tem como segunda acepção "próprio ou de uso exclusivo por alguém, privativo, privado".
} 
Em relação à organização acadêmica das instituições, em observância à legislação e à regulamentação infralegal, as instituições podem se caracterizar como: ${ }^{295}$ (a) faculdade, que inclui institutos e organizações equiparadas; (b) centro universitário, dotado de autonomia para a criação de cursos e vagas na sede e obrigado a manter um terço de mestres ou doutores e um quinto do corpo docente em tempo integral; (c) universidade, dotada de autonomia na sede, podendo criar campus fora de sede no âmbito do Estado e obrigada a manter um terço de mestres ou doutores e um terço do corpo docente em tempo integral; (d) instituto federal de educação ciência e tecnologia, que, para efeitos regulatórios, equipara-se a universidade tecnológica; e (e) centro federal de educação tecnológica, que, para efeitos regulatórios, equipara-se a centro universitário. ${ }^{296}$

\subsubsection{Conceitos relativos a cursos superiores}

Segundo a LDB, a educação superior abrange os seguintes cursos $\boldsymbol{e}$ programas: (a) cursos sequenciais por campo de saber, de diferentes níveis de abrangência, abertos a candidatos que atendam aos requisitos estabelecidos pelas instituições de ensino, desde que tenham concluído o ensino médio ou equivalente; (b) cursos de graduação, abertos a candidatos que tenham concluído o ensino médio ou equivalente e tenham sido classificados em processo seletivo; (c) cursos de pós-graduação, compreendendo programas de mestrado e doutorado, cursos de especialização, aperfeiçoamento e outros, abertos a candidatos diplomados em cursos de graduação e que atendam às exigências das instituições de ensino; (d) cursos de extensão, abertos a candidatos que atendam aos requisitos estabelecidos em cada caso pelas instituições de ensino. $^{297}$

Cumpre delimitar que a presente tese tem como objeto a atividade regulatória estatal sobre os cursos de graduação, sendo que, para tanto, estudará, também, normas infralegais disciplinadoras desses cursos.

Em relação aos turnos de oferta de cursos, os cursos superiores podem ser classificados como: (a) matutinos, cursos em que a maior parte da carga horária é oferecida até às $12 \mathrm{~h}$ todos os dias da semana; (b) vespertinos, cursos em que a maior parte da carga

\footnotetext{
${ }^{295}$ As universidades e centros universitários foram abordados em subcapítulo próprio (cf. 2.2.2).

${ }^{296}$ Portaria Normativa no 40/2007, Anexo, item 3.

${ }^{297}$ LDB, artigo 44.
} 
horária é oferecida entre $12 \mathrm{~h}$ e $18 \mathrm{~h}$ todos os dias da semana; (c) noturnos, cursos em que a maior parte da carga horária é oferecida após as 18h todos os dias da semana; e (d) integrais, cursos ofertados inteira ou parcialmente em mais de um turno (manhã e tarde, manhã e noite, ou tarde e noite) exigindo a disponibilidade do estudante por mais de 6 horas diárias durante a maior parte da semana. ${ }^{298}$

O conceito de temporalidade dos cursos busca trazer a noção de periodicidade, ou seja, do intervalo de tempo em que se organizam as atividades de ensino, perfazendo a carga horária determinada pelo projeto pedagógico do curso para um conjunto de componentes curriculares. As formas mais usuais são as semestral ou anual, embora, em casos específicos, justificados pelas características do projeto pedagógico, possa haver outro regime, como trimestral ou quadrimestral. Entende-se por integralização a duração do curso, ou seja, o prazo previsto para que o estudante receba a formação pretendida, cujo tempo total deve ser descrito em anos ou fração. ${ }^{299}$

No que diz respeito à modalidade dos cursos, tem-se (a) a presencial, que pressupõe a presença física do estudante nas atividades didáticas e avaliações; e (b) a $a ̀$ distância, no qual a mediação nos processos de ensino e aprendizagem ocorre com a utilização de meios e tecnologias de informação e comunicação, com estudantes e professores desenvolvendo atividades educativas em lugares ou tempos diversos. ${ }^{300}$

Um aspecto extremamente relevante, dado seu importante impacto na atividade regulatória da educação superior se refere aos locais de oferta dos cursos, que podem ser: (a) campus, local onde se oferece uma gama ampla de atividades administrativas e educacionais da instituição, incluindo espaços para oferta de cursos, bibliotecas, laboratórios e áreas de prática para estudantes e professores, e também reitorias, próreitorias, coordenação de cursos, secretaria, funcionamento de colegiados acadêmicos e apoio administrativo; (b) unidade, local secundário da instituição, onde se exercem apenas atividades educacionais ou administrativas; (c) campus sede, local principal de funcionamento da instituição, incluindo os órgãos administrativos e acadêmicos centrais, a oferta dos cursos e as demais atividades educacionais. (para fins regulatórios, o Município em que se situa a sede da instituição delimita o exercício de prerrogativas de autonomia, no caso de universidades e centros universitários); (d) campus fora de sede, local secundário

\footnotetext{
${ }^{298}$ Portaria Normativa no 40/2007, Anexo, item 5.

${ }^{299}$ Portaria Normativa n ${ }^{\circ} 40 / 2007$, Anexo, item 6.

${ }^{300}$ Portaria Normativa n ${ }^{\circ} 40 / 2007$, Anexo, item 7.
} 
de funcionamento da instituição, fora do Município onde se localiza a sede da instituição e se oferecem cursos e realizam atividades administrativas (é restrito às universidades e depende de credenciamento específico, em regra não gozando de prerrogativas de autonomia); (e) unidade educacional na sede, local secundário de oferta de cursos e atividades educacionais no Município em que funciona a sede da instituição; (f) unidade educacional fora de sede, local secundário de oferta de cursos e atividades educacionais em Município distinto daquele em que funciona a sede da instituição, incluindo fazendas, hospitais e qualquer outro espaço em que se realizem atividades acadêmicas, conforme previsão no ato de credenciamento do campus fora de sede; (g) unidade administrativa, local secundário de realização de atividades exclusivamente administrativas; (h) núcleo de educação à distância (EAD), unidade responsável pela estruturação da oferta de EAD na instituição, compreendendo as atividades educacionais e administrativas, incluídas a criação, gestão e oferta de cursos com suporte tecnológico, bem como a administração, produção de materiais didáticos e recursos próprios da EAD; (i) polo de apoio presencial de $E A D$, unidade operacional para o desenvolvimento descentralizado de atividades pedagógicas e administrativas relativas aos cursos e programas ofertados a na modalidade de educação a distância; e (j) agrupador, endereço principal de um campus ou unidade educacional, que agrega endereços vizinhos ou muito próximos, no mesmo município, no qual as atividades acadêmicas ou administrativas se dão com algum nível de integração. ${ }^{301}$

As diretrizes curriculares nacionais, que vieram substituir aos antigos currículos mínimos dos cursos de graduação, constituem orientações para a elaboração dos currículos, que devem ser respeitadas pelas instituições de ensino superior, inclusive pelas universidades, no exercício de sua autonomia ${ }^{302}$. As diretrizes curriculares nacionais se diferenciam dos parâmetros curriculares, que são referenciais curriculares detalhados e não obrigatórios. Compete ao Conselho Nacional de Educação deliberar sobre as diretrizes curriculares propostas pelo Ministério da Educação para os cursos de graduação. ${ }^{303}$

\subsubsection{Conceitos relativos a docentes e alunos}

O corpo docente é uma importante dimensão de avaliação de instituições e cursos. Sua titulação e regime de contratação constituem requisitos fundamentais para o

\footnotetext{
${ }^{301}$ Portaria Normativa n ${ }^{\circ}$ 40/2007, Anexo, item 8.

${ }^{302}$ LDB, artigo 53, II.

${ }^{303}$ Lei n ${ }^{\circ} 9.131 / 1995$, artigo 90, $§ 2^{\circ}$, “c".
} 
credenciamento de universidades e centros universitários. ${ }^{304}$ No que diz respeito a seu regime de contratação, os professores podem ser enquadrados como: (a) em tempo integral, contratados com 40 horas semanais de trabalho na mesma instituição, reservado o tempo de pelo menos 20 horas semanais a estudos, pesquisa, trabalhos de extensão, gestão, planejamento, avaliação e orientação de estudantes; (b) em tempo parcial, contratados para atuação com 12 ou mais horas semanais de trabalho na mesma instituição, reservado pelo menos $25 \%$ do tempo para estudos, planejamento, avaliação e orientação de estudantes; e (c) horistas, contratados pela instituição exclusivamente para ministrar aulas, independentemente da carga horária contratada, ou que não se enquadrem nos outros regimes de trabalho acima definidos. ${ }^{305}$

Além disso, o núcleo docente estruturante (NDE) é o conjunto de professores da instituição responsável pela formulação do projeto pedagógico do curso, sua implementação e desenvolvimento, detalhado em subcapítulo próprio. ${ }^{306}$

A matrícula dos estudantes, que constitui o vínculo formal do estudante a um curso superior, pode ser (a) ativa, que corresponde à realização de disciplinas ou atividades previstas no projeto pedagógico ou ainda à conclusão do curso no ano de referência; ou (b) inativa, sem correspondência com atividades acadêmicas. Matriculado é o estudante vinculado formalmente a curso superior. Ingressante é o estudante que efetiva a matrícula inicial no curso, (a) por meio de processo seletivo, quando a primeira matrícula no curso é efetivada após a realização deste; ou (b) por outras formas de ingresso que dispensam processo seletivo, quando o estudante realiza a matrícula no curso na condição de portador de diploma de curso superior ou em virtude de mudança de curso dentro da mesma instituição, transferência de outra instituição, ou acordo internacional. Concluinte é o estudante que tenha expectativa de concluir o curso no ano de referência, considerando o cumprimento de todos os requisitos para a integralização do curso em todos os componentes curriculares. Inscrito é o estudante que se inscreve para participar de processo seletivo de ingresso em curso superior. Desistente é o estudante que interrompe o vínculo formal com o curso em que estava matriculado. ${ }^{307}$

\footnotetext{
${ }^{304}$ Cf. 2.2.2.

${ }^{305}$ Portaria Normativa n ${ }^{\circ} 40 / 2007$, Anexo, item 9.

${ }^{306}$ Cf. 5.5.1.5.

${ }^{307}$ Portaria Normativa no 40/2007, Anexo, item 10.
} 
No que diz respeito às vagas, importante aspecto regulatório da educação superior, tem-se, como (a) autorizadas, o número de lugares destinados ao ingresso de estudantes em curso superior, expressas em ato autorizativo, correspondente ao total anual, que a instituição pode distribuir em mais de um processo seletivo (no caso das instituições autônomas, consideram-se autorizadas as vagas aprovadas pelos colegiados acadêmicos competentes e regularmente informadas ao Ministério da Educação); e como (b) oferecidas, o número total de vagas disponibilizadas nos processos seletivos constantes dos editais expedidos pela instituição. ${ }^{308}$

\subsubsection{Garantia de padrão de qualidade e regulação da educação superior}

Conforme visto, ${ }^{309}$ a Constituição estabelece o princípio da garantia de padrão da qualidade na educação, ${ }^{310}$ explicitado também pela LDB, por meio do estabelecimento de padrões mínimos de qualidade de ensino, definidos como a variedade e quantidade mínimas, por aluno, de insumos indispensáveis ao desenvolvimento do processo de ensinoaprendizagem. ${ }^{311}$ Para tanto, devem ser estabelecidos parâmetros objetivos que servem como orientação nesta matéria, tais como o grau de formação dos professores, a disponibilidade de material didático e de apoio, a adequação de currículos à realidade local, a implantação de sistemas de avaliação, bem como a melhoria da remuneração e condições de trabalho dos professores. ${ }^{312}$

O estabelecimento do princípio da garantia de padrão da qualidade na educação superior, estabelecido na Constituição e na legislação brasileiras, se coaduna com os objetivos apresentados na Conferência Mundial sobre Ensino Superior, de 2009, que, nos termos do documento As Novas Dinâmicas do Ensino Superior e Pesquisas para a Mudança e o Desenvolvimento Social:

“19. Expandir o acesso traz desafios à qualidade do ensino superior. Garantia de qualidade é uma função fundamental na educação superior contemporânea e deve envolver investidores. Qualidade requer estabelecer sistemas que garantam a qualidade e padrões de avaliação assim como promover a qualidade cultural dentro das instituições.

\footnotetext{
${ }^{308}$ Portaria Normativa n ${ }^{\circ}$ 40/2007, Anexo, item 11.

${ }^{309}$ Cf. 1.2.5.2.

${ }^{310}$ Constituição da Republica Federativa do Brasil, artigo 206, VII.

${ }^{311} \mathrm{Cf}$. LDB, artigo $4^{\circ}$, IX.

${ }^{312}$ Cf. Clarice Seixas Duarte, "A educação como um direito fundamental de natureza social”, Educação \& Sociedade 100 (2007), p. 706.
} 
20. Mecanismos que garantem a qualidade e promovem acesso e criam condições para a conclusão dos estudos devem ser postos em prática em todo o setor de ensino superior.

21. Critérios de qualidade devem refletir todos os objetivos da educação superior, notavelmente o propósito de cultivar o pensamento crítico e independente nos estudantes e a capacidade de aprender por toda a vida. Eles devem estimular a inovação e a diversidade. Garantir a qualidade do ensino superior requer o reconhecimento da importância de se atrair e reter uma equipe de ensino e pesquisa comprometida, talentosa e qualificada."

Nesse sentido, a LDB apresenta, em seu artigo 46, o dispositivo fundamental para o estabelecimento da atividade regulatória da educação superior com vistas à garantia de padrões de qualidade, por meio da expedição de atos autorizativos e da concessão de prazo para saneamento de deficiências:

“Art. 46. A autorização e o reconhecimento de cursos, bem como o credenciamento de instituições de educação superior, terão prazos limitados, sendo renovados, periodicamente, após processo regular de avaliação.

$\S 1^{\circ}$ Após um prazo para saneamento de deficiências eventualmente identificadas pela avaliação a que se refere este artigo, haverá reavaliação, que poderá resultar, conforme o caso, em desativação de cursos e habilitações, em intervenção na instituição, em suspensão temporária de prerrogativas da autonomia, ou em descredenciamento.

$\S 2^{\text {o }}$ No caso de instituição pública, o Poder Executivo responsável por sua manutenção acompanhará o processo de saneamento e fornecerá recursos adicionais, se necessários, para a superação das deficiências."

Aqui estão presentes os elementos fundamentais da atividade regulatória estatal em matéria educacional, que regulamentam, no plano legal, o artigo 209 da Constituição: (a) a necessidade dos atos administrativos regulatórios, de caráter autorizativo (autorização e o reconhecimento de cursos, bem como o credenciamento de instituições de educação superior); (b) o prazo limitado de tais atos, ensejando a necessidade de sua renovação periódica; (c) a existência do processo regular de avaliação para a expedição desses atos; (d) a possibilidade de saneamento de eventuais deficiências apontadas no processo de avaliação, durante um prazo determinado; e (e) a possibilidade da aplicação de sanções administrativas (desativação de cursos e habilitações, intervenção na instituição, suspensão temporária de prerrogativas da autonomia, ou descredenciamento, conforme o caso). 
Essas bases da atividade regulatória educacional são completadas pela Lei $\mathrm{n}^{\circ}$ 10.861, de 14 de abril de 2004 - Lei do SINAES - e por regulamentação administrativa infralegal, que será estudada detalhadamente em capítulo próprio. ${ }^{313}$

\subsection{Plano Nacional de Educação e as metas relativas à educação superior}

A Lei n 10.172/2001, que aprovou o Plano Nacional de Educação (PNE), com duração de dez anos, estabeleceu objetivos e metas a serem atingidos. Merecem destaque alguns deles, relativos à educação superior:

“4.3 Objetivos e Metas

1. Prover, até o final da década, a oferta de educação superior para, pelo menos, $30 \%$ da faixa etária de 18 a 24 anos.

$[\ldots]$

3. Estabelecer uma política de expansão que diminua as desigualdades de oferta existentes entre as diferentes regiões do País.

$[\ldots]$

6. Institucionalizar um amplo e diversificado sistema de avaliação interna e externa que englobe os setores público e privado, e promova a melhoria da qualidade do ensino, da pesquisa, da extensão e da gestão acadêmica.

$[\ldots]$

9. Estabelecer sistema de recredenciamento periódico das instituições e reconhecimento periódicos dos cursos superiores, apoiado no sistema nacional de avaliação.”

Apesar da ampliação expressiva do acesso à educação superior nas duas últimas décadas, o país ainda se encontra muito aquém da meta quantitativa estabelecida pelo PNE, assim como não foram plenamente atingidas às metas de diminuição da desigualdade regional da oferta. É certo que a ampliação desejada deve se concretizar, em parte significativa, por vagas na rede pública, mas também pela oferta por meio do setor privado. Nesse sentido, cabe ao Estado, principalmente, (a) ampliar a oferta de educação superior pela rede pública; (b) regular a expansão da oferta, zelando pela qualidade dos cursos e instituições públicas e privadas; e (c) implementar políticas públicas de democratização do acesso à educação superior, por meio da criação de mecanismos de ingresso e permanência de estudantes de baixa renda.

${ }^{313}$ Cf. Capítulo 4. 
O Poder Executivo enviou à Câmara dos Deputados o Projeto de Lei $\mathrm{n}^{\circ}$ 8.035/2010, que visa à aprovação do Plano Nacional de Educação para o decênio 20112020, estabelecendo metas e estratégias, sem estabelecer uma divisão tópica entre os níveis educacionais. Em linhas gerais, as metas são estabelecidas para a sociedade como um todo, e as estratégias competem ao Poder Público, por meio de políticas públicas integradas. Em relação direta com o objeto do presente trabalho, tem-se a Meta 12, de caráter quantitativo:

"Meta 12: Elevar a taxa bruta de matrícula na educação superior para 50\% e a taxa líquida para $33 \%$ da população de 18 a 24 anos, assegurando a qualidade da oferta."

Para que tal meta quantitativa seja alcançada, são estabelecidas, entre outras, as seguintes estratégias:

“12.6) Expandir o financiamento estudantil por meio do Fundo de Financiamento ao estudante do Ensino Superior - FIES, de que trata a Lei $\mathrm{n}^{\circ}$ 10.260, de 12 de julho de 2001, por meio da constituição de fundo garantidor do financiamento de forma a dispensar progressivamente a exigência de fiador.

\section{$[\ldots]$}

12.9) Ampliar a participação proporcional de grupos historicamente desfavorecidos na educação superior, inclusive mediante a adoção de políticas afirmativas, na forma da lei.

12.10) Assegurar condições de acessibilidade nas instituições de educação superior, na forma da legislação.

12.11) Fomentar estudos e pesquisas que analisem a necessidade de articulação entre formação, currículo e mundo do trabalho, considerando as necessidades econômicas, sociais e culturais do País.

$[\ldots]$

12.14) Mapear a demanda e fomentar a oferta de formação de pessoal de nível superior considerando as necessidades do desenvolvimento do país, a inovação tecnológica e a melhoria da qualidade da educação básica.”

Ao lado da meta quantitativa, o projeto prescreve a Meta 13, de caráter qualitativo:

"Meta 13: Elevar a qualidade da educação superior pela ampliação da atuação de mestres e doutores nas instituições de educação superior para 75\%, no mínimo, do corpo docente em efetivo exercício, sendo, do total, $35 \%$ doutores.”

Para que tal meta qualitativa seja alcançada, são estabelecidas as seguintes estratégias: 
“13.1) Aprofundar e aperfeiçoar o Sistema Nacional de Avaliação da Educação Superior SINAES, de que trata a Lei $n^{\circ} 10.861$, de 14 de abril de 2004, fortalecendo as ações de avaliação, regulação e supervisão.

13.2) Ampliar a cobertura do Exame Nacional de Desempenho de Estudantes - ENADE, de modo a que mais estudantes, de mais áreas, sejam avaliados no que diz respeito à aprendizagem resultante da graduação.

13.3) Induzir processo contínuo de auto-avaliação das instituições superiores, fortalecendo a participação das comissões próprias de avaliação, bem como a aplicação de instrumentos de avaliação que orientem as dimensões a serem fortalecidas, destacando-se a qualificação e a dedicação do corpo docente.

13.4) Induzir a melhoria da qualidade dos cursos de pedagogia e licenciaturas, por meio da aplicação de instrumento próprio de avaliação aprovado pela CONAES, de modo a permitir aos graduandos a aquisição das competências necessárias a conduzir o processo de aprendizagem de seus futuros alunos, combinando formação geral e prática didática.

13.5) Elevar o padrão de qualidade das universidades, direcionando sua atividade de modo que realizem, efetivamente, pesquisa institucionalizada, na forma de programas de pós-graduação stricto sensu.

13.6) Substituir o Exame Nacional de Desempenho dos Estudantes - ENADE aplicado ao final do primeiro ano do curso de graduação pelo Exame Nacional do Ensino Médio - ENEM, a fim de apurar o valor agregado dos cursos de graduação.

13.7) Fomentar a formação de consórcios entre universidades públicas de educação superior com vistas a potencializar a atuação regional, inclusive por meio de plano de desenvolvimento institucional integrado, assegurando maior visibilidade nacional e internacional às atividades de ensino, pesquisa e extensão.”

Após quase dois anos de tramitação, a Câmara dos Deputados aprovou o projeto de lei, com alterações. No que se refere aos dispositivos acima transcritos, além de pequenas alterações de redação, pode-se destacar as seguintes alterações substanciais aprovadas:

(a) Meta 12: o aumento estabelecido nas taxas brutas e líquidas de matrícula deve se realizar com pelo menos $40 \%$ (quarenta por cento) das novas matrículas em instituições públicas ${ }^{314}$ indicando uma política de expansão da educação superior que tenha papel significativo das instituições públicas; ${ }^{315}$ ${ }^{314}$ Projeto de Lei $\mathrm{n}^{\circ}$ 8.035/2010 aprovado pela Câmara dos Deputados: "Meta 12: elevar a taxa bruta de
matrícula na educação superior para 50\% (cinquenta por cento) e a taxa líquida para $33 \%$ (trinta e três por 
(b) Meta 13: alteração da expressão "ampliação da atuação de mestres $e$ doutores" para "ampliação da proporção de mestres e doutores do corpo docente em efetivo exercício", ${ }^{316}$ a fim de deixar clara a necessidade do estabelecimento de indicadores quantitativos da atuação de docentes com essa titulação;

(c) Estratégia 13.1: em relação ao SINAES, alteração da expressão "aprofundar e aperfeiçoar" por "aperfeiçoar", 317 apontando para a concepção de que esse sistema já tem o seu campo de atuação definido;

(d) Estratégia 13.5: no que diz respeito às universidades a substituição da determinação de que a pesquisa institucionalizada deve se dar "na forma de programas de pós-graduação stricto sensu", ${ }^{318}$ para a determinação de que ela deve ser "articulada" a tais programas, possivelmente com a intenção de que possam vir a ser consideradas atividades de pesquisa realizada em parceria com programas de pós-graduação de outras universidades.

O projeto de lei aprovado pela Câmara dos Deputados foi encaminhado ao Senado Federal, onde atualmente tramita como Projeto de Lei no 103/2012. Embora não se trate de lei aprovada, o Plano Nacional de Educação provavelmente será aprovado nesse ano. De modo geral, o projeto aprovado pela Câmara não alterou um sistema diretamente relacionado com o objeto do presente trabalho: a articulação entre as metas quantitativas e qualitativas, estabelecendo o desafio de conciliar a ampliação quantitativa do acesso ampliando a efetividade do direito à educação superior - com a consolidação de um sistema regulatório que garanta a elevação da qualidade nesse nível educacional. Para o cumprimento dessas metas, é importante que a lei que venha a instituir o plano mantenha o

cento) da população de 18 (dezoito) a 24 (vinte e quatro) anos, assegurada a qualidade da oferta e expansão para, pelo menos, $40 \%$ (quarenta por cento) das novas matrículas, no segmento público".

${ }^{315}$ Essa modificação relaciona-se com outra alteração aprovada pela Câmara dos Deputados do projeto de lei original: o estabelecimento do percentual de $10 \%$ do Produto Interno Bruto na educação pública, até o final da vigência do plano, ante o percentual de $7 \%$ originalmente estabelecido.

316 Projeto de Lei no 8.035/2010 aprovado pela Câmara dos Deputados: "Meta 13: elevar a qualidade da educação superior pela ampliação da proporção de mestres e doutores do corpo docente em efetivo exercício no conjunto do sistema de educação superior para $75 \%$ (setenta e cinco por cento), sendo, do total, no mínimo 35\% (trinta e cinco por cento) doutores".

317 Projeto de Lei $\mathrm{n}^{\circ}$ 8.035/2010 aprovado pela Câmara dos Deputados: “13.1) aperfeiçoar o Sistema Nacional de Avaliação da Educação Superior - SINAES, de que trata a Lei nº 10.861, de 14 de abril de 2004, fortalecendo as ações de avaliação, regulação e supervisão".

${ }^{318}$ Projeto de Lei n 8.035/2010 aprovado pela Câmara dos Deputados: "13.5) elevar o padrão de qualidade das universidades, direcionando sua atividade, de modo que realizem, efetivamente, pesquisa institucionalizada, articulada a programas de pós-graduação stricto sensu". 
estabelecimento do percentual de $10 \%$ (dez por cento) do Produto Interno Bruto na educação pública, até o final de sua vigência. 


\title{
Capítulo 3 FUNDAMENTOS DA REGULAÇÃO DA EDUCAÇÃO SUPERIOR
}

\subsection{Natureza jurídica da atividade educacional}

Um importante aspecto a ser analisado, a fim de que seja delimitada a atividade regulatória sobre a educação superior, refere-se à natureza jurídica da atividade educacional, que apresenta muita controvérsia doutrinária, principalmente em relação a seu exercício por instituições educacionais privadas.

Tradicionalmente, a fim de se analisar a natureza jurídica de determinada atividade que tem algum conteúdo econômico, parte-se dos regimes jurídicos estabelecidos pelos artigos 173 e 175 da Constituição, que tratam, respectivamente, da atividade econômica e do serviço público, ambos situados no capítulo que trata dos princípios gerais da atividade econômica:

\author{
“TÍTULO VII \\ Da Ordem Econômica e Financeira \\ CAPÍTULO I \\ DOS PRINCÍPIOS GERAIS DA ATIVIDADE ECONÔMICA
}

$[\ldots]$

Art. 173. Ressalvados os casos previstos nesta Constituição, a exploração direta de atividade econômica pelo Estado só será permitida quando necessária aos imperativos da segurança nacional ou a relevante interesse coletivo, conforme definidos em lei.

$[\ldots]$

Art. 175. Incumbe ao Poder Público, na forma da lei, diretamente ou sob regime de concessão ou permissão, sempre através de licitação, a prestação de serviços públicos.”

A fim de superar a ambiguidade do texto constitucional - que trata atividade econômica como gênero e espécie, Eros Roberto Grau defende posição de que atividade 
econômica em sentido amplo, como gênero, engloba a atividade econômica em sentido estrito (objeto do artigo 173) e o serviço público (tratado pelo artigo 175). ${ }^{319}$

No entanto, essa distinção não é suficiente para a compreensão da atividade educacional, que não se situa sob a disciplina do artigo 173 (uma vez que a prestação dessa atividade pelo Estado é principal e obrigatória, nos termos da Constituição), tampouco se submete ao artigo 175, já que sua prestação por parte do particular não se faz por meio de concessão ou permissão, precedida de licitação, mas, nos termos do artigo 209, é livre à iniciativa privada, por meio de autorização, desde que haja cumprimento das normas gerais da educação nacional, sendo submetido à avaliação de qualidade pelo Poder Público.

Dessa maneira, a educação não se trata de atividade econômica em sentido estrito, submetida ao artigo 173, tampouco de serviço público, nos estritos termos do artigo 175. Essa situação demonstra que não há apenas esses dois regimes jurídicos, mas também outros previstos no próprio texto constitucional.

No que se refere às atividades econômicas em sentido estrito, há uma série de regimes jurídicos diferentes no que se refere ao condicionamento de sua exploração por particulares. Algumas dessas atividades exigem autorização estatal para que o particular possa desenvolver.

Da mesma forma, há também diferentes regimes jurídicos para a prestação de serviços públicos, diferentes daquele previsto no artigo 175 da Constituição. Por essa razão, o conceito de serviço público tem se mostrado extremamente controvertido, ensejando atualmente um intenso debate doutrinário para sua delimitação. O presente trabalho não pretende esgotar esse assunto, mas busca trazer algumas diferentes visões desse assunto, a fim de procurar compreender a natureza jurídica da atividade educacional.

Maria Sylvia Zanella di Pietro apresenta o seguinte conceito de serviço público em sentido amplo, a fim de distinguí-lo das demais atividades administrativas de natureza pública: "toda atividade material que a lei atribui ao Estado para que a exerça diretamente

\footnotetext{
${ }^{319}$ Cf. Eros Roberto Grau, A ordem econômica na Constituição de 1988. 14. ed. São Paulo: Malheiros, 2010, p. 101-102.
} 
ou por meio de seus delegados, com o objetivo de satisfazer concretamente às necessidades coletivas, sob regime jurídico total ou parcialmente público." ${ }^{320}$

Marçal Justen Filho apresenta um conceito de serviço público que, no que diz respeito a seu aspecto material, ressalta sua relação com a efetivação de direitos fundamentais:

\begin{abstract}
"Serviço público é uma atividade pública administrativa de satisfação concreta de necessidades individuais ou transindividuais, materiais ou imateriais, vinculadas diretamente a um direito fundamental, insuscetíveis de satisfação adequada mediante os mecanismos da livre iniciativa privada, destinada a pessoas indeterminadas, qualificada legislativamente e executada sob regime de direito público.",321
\end{abstract}

Alexandre Santos de Aragão, de forma didática, apresenta diferentes concepções de serviço público tendo por referência a amplitude do conceito e demonstrando o quão diverso pode ser esse conceito. Segundo o autor, o serviço público, segundo o tratamento constitucional, pode apresentar as concepções amplíssima, ampla, restrita e restritíssima. ${ }^{322}$ Por essa visão, a concepção amplíssima de serviço público decorre da escola clássica do serviço público, de Léon Duguit, pois abrangeria todas as atividades exercidas pelo Estado. ${ }^{323}$ A concepção ampla do serviço público, por seu turno, corresponderia às atividades prestacionais, em geral, desenvolvidas pelo Estado: "funções que exerce para proporcionar diretamente aos indivíduos comodidades e utilidades, independentemente de poderem deles ser cobradas individualmente ou não, ou de serem de titularidade exclusiva do Estado". ${ }^{324} \mathrm{Na}$ visão do autor, essa categoria incluiria os serviços públicos econômicos, remunerados por taxas ou tarifas, os serviços sociais, que podem ser sem pela iniciativa privada, sem a necessidade de delegação, e os serviços uti universi, sem beneficiários identificáveis com exatidão. ${ }^{325}$ Por seu turno, a concepção restrita de serviço público incluiria "apenas as atividades prestacionais que tivessem um liame imediato com os indivíduos, podendo os seus beneficiários ser identificados e a sua fruição quantificada", ${ }^{326}$ excluindo-se, portanto, os serviços uti universi. Por último, a concepção restritíssima de serviço público, teria por base os artigos 145, II, e 175, da Constituição,

\footnotetext{
${ }^{320}$ Maria Sylvia Zanella di Pietro, Direito administrativo, 25. ed., São Paulo: Atlas, 2012, p. 106.

${ }^{321}$ Marçal Justen Filho, Curso de Direito Administrativo, p. 687.

${ }^{322}$ Cf. Alexandre Santos de Aragão, Direito dos serviços públicos, 2. ed., Rio de Janeiro: Forense, 2008, pp. 144-149.

${ }^{323}$ Cf. Alexandre Santos de Aragão, Direito dos serviços públicos, p. 144.

${ }^{324}$ Alexandre Santos de Aragão, Direito dos serviços públicos, p. 148.

${ }^{325}$ Cf. Alexandre Santos de Aragão, Direito dos serviços públicos, p. 148.

${ }^{326}$ Alexandre Santos de Aragão, Direito dos serviços públicos, p. 148.
} 
incluindo os serviços que podem ser remunerados especificamente por meio de taxa ou tarifa, bem como que são de titularidade exclusiva do Estado, exploráveis pela iniciativa privada apenas mediante concessão ou permissão. ${ }^{327}$

Analisando-se as quatro concepções de serviço público apresentada pelo autor, percebe-se que os serviços sociais - educação e saúde - estariam excluídos apenas da última - concepção restritíssima de serviço público. Para o autor, o terceiro conceito seria “o mais operacional por contemplar um conjunto de atividades [...] que, apesar de não terem regimes jurídicos idênticos [...], possuem um mínimo de pontos em comum ("unidade de sentido") capaz de justificar sua inclusão no mesmo conceito". ${ }^{328}$ Nessa linha, Alexandre Santos de Aragão apresenta o seguinte conceito de serviço público, ressaltando a importância da responsabilidade do Estado sobre a prestação, com ou sem reserva de titularidade, ${ }^{329}$ para sua caracterização:

"Serviços públicos são as atividades de prestação de utilidades econômicas a indivíduos determinados, colocadas pela Constituição ou pela Lei a cargo do Estado, com ou sem reserva de titularidade, e por ele desempenhadas diretamente ou por seus delegatários, gratuita ou remuneradamente, com vistas ao bem estar da coletividade., 330

O conceito acima apresentado compreende a atividade educacional, uma vez que esta, mesmo sem apresentar reserva de titularidade estatal, constitui utilidade econômica a indivíduos determinados, é colocada pela Constituição sob a responsabilidade do Estado. Entretanto, o autor, de forma expressa, entende que tal atividade constituem atividades econômicas privadas:

\footnotetext{
"Entendemos, no entanto, [...] que [...] essas atividades (saúde, educação etc.) devem ser denominadas em seu conjunto como "serviços compartidos", sendo que, quando exploradas pelos particulares, são atividades econômicas privadas, eventualmente de interesse público ou regulamentadas [...], e, quando exploradas pelo Poder Público, são serviços públicos sociais, espécie classificatória do gênero serviço público caracterizada, ao contrário dos demais serviços públicos, pela inexistência da reserva da titularidade estatal." ${ }^{331}$
}

Existe uma profunda controvérsia no que se refere à natureza jurídica da atividade educacional quando desenvolvida pela iniciativa privada. Há doutrinadores que

\footnotetext{
${ }^{327}$ Cf. Alexandre Santos de Aragão, Direito dos serviços públicos, p. 149.

${ }^{328}$ Alexandre Santos de Aragão, Direito dos serviços públicos, p. 157.

${ }^{329}$ Cf. Alexandre Santos de Aragão, Direito dos serviços públicos, p. 161.

${ }^{330}$ Alexandre Santos de Aragão, Direito dos serviços públicos, p. 157.

${ }^{331}$ Alexandre Santos de Aragão, Direito dos serviços públicos, p. 185.
} 
entendem que a educação é serviço público somente quando prestada pelo Estado - sendo, portanto, atividade econômica em sentido estrito. Outros estudiosos que a atividade educacional se consubstancia sempre como serviço público, dada sua relação com a efetividade dos direitos sociais. ${ }^{332}$

$\mathrm{Na}$ posição de que tem natureza jurídica de atividade econômica em sentido estrito a atividade educacional desenvolvida pela iniciativa privada, Carlos Ari Sundfeld classifica a educação como serviço social, que se diferenciam dos serviços públicos por não serem de titularidade estatal: ${ }^{333}$

"Tais serviços se desenvolvem, portanto, em setores não reservados ao Estado, mas livres aos particulares. Daí uma importante consequência: quando prestados pelo Poder Público, submetem-se ao regime de direito público; quando prestados pelos particulares, sujeitam-se ao regime de direito privado." 334

Na mesma linha, Paulo Modesto entende que a educação não é serviço público quando desempenhada por particulares, pois a Constituição incluiu determinadas atividades na categoria de serviços públicos apenas quando prestadas pelo Estado, como saúde e educação. ${ }^{335}$

Nina Beatriz Ranieri entende que, embora a atividade educacional desenvolvida pela iniciativa privada não possa ser caracterizada como serviço público, pelo fato de não haver a necessidade de delegação ao particular, nesse caso, a natureza pública da atividade educacional determina a derrogação parcial de prerrogativas inerentes ao regime privado, por normas de direito público. Dessa forma, se via de regra, há grande liberdade para exercício das atividades econômicas em geral, isso não se verifica na área educacional. $^{336}$

Há, no entanto, posicionamento doutrinário no sentido de que a atividade educacional não pode ser considerada como serviço público, tampouco como atividade econômica em sentido estrito. Para Fernando Herren Aguillar, na ordem constitucional, há uma nítida divisão entre serviços públicos - que competem em regra ao Estado (artigo

\footnotetext{
332 Vladmir Oliveira da Silveira / Irene Patrícia Nohara, "Supervisão do ensino superior de direito no contexto federativo e complexidades do controle da pós-graduação stricto sensu", pp. 283-284.

${ }_{333}$ Cf. Carlos Ari Sundfeld, Fundamentos de direito público, 5. ed., São Paulo: Malheiros, 2012, pp. 83-84.

${ }^{334}$ Carlos Ari Sundfeld, Fundamentos de direito público, p. 84.

${ }^{335}$ Cf. Paulo Modesto, "Reforma administrativa e marco legal das organizações sociais no Brasil", pp. 208209.

${ }^{336}$ Cf. Nina Beatriz Stocco Ranieri, Educação Superior, Direito e Estado, pp. 129-135.
} 
175), e atividades econômicas em sentido estrito - que cabem, em regra, aos particulares (artigo 173). ${ }^{337}$ Segundo o autor, "se uma atividade puder ser desempenhada por particulares sem concessão ou permissão, ela não pode ser considerada serviço público". 338 Por essa linha de raciocínio, as atividades relativas à saúde e à educação são serviços públicos quando desempenhadas pelo Estado, mas não o são quando desempenhadas pela iniciativa privada. ${ }^{339}$ Por essa razão, o autor classifica a educação e a saúde como "funções irrenunciáveis do Estado, [...] mas que na atual sistemática constitucional podem ser desempenhadas livremente pela iniciativa privada", 340 conforme explica:

“Os serviços de saúde e de educação são necessariamente desenvolvidos pelo Estado, que não pode deixar de fazê-lo. Porém na atual sistemática constitucional, saúde e educação são atividades livres aos particulares que desejarem explorá-las." 341

Por outro lado, há posicionamentos doutrinários no sentido de que a atividade educacional, mesmo quando desenvolvida por particulares, constitui serviço público. Nesse sentido, Floriano Peixoto Marques Neto expõe um universo amplo de serviços públicos, que podem ser classificados de acordo com o regime jurídico a que se submetem: (a) aqueles delegáveis a particulares por opção do poder público; ${ }^{342}$ (b) aqueles que devem ser objeto de delegação ao menos parcial; ${ }^{343}$ e (c) aqueles para os quais se admite a participação da iniciativa privada em caráter complementar ou suplementar. ${ }^{344}$

Por essa classificação, os serviços públicos para os quais se admite a participação da iniciativa privada em caráter complementar ou suplementar seriam os de saúde e educação (regidos pelos artigos 199 e 209, da Constituição, respectivamente). São atividades que, embora consideradas como serviço público, levaram o Constituinte a limitar a discricionariedade do poder público, prevendo sua exploração pelo particular, sem necessidade de concessão ou permissão, mas com a exigência, em alguns casos, de autorização, submetido a um regime regulatório forte. ${ }^{345}$

\footnotetext{
${ }^{337}$ Cf. Fernando Herren Aguillar, Controle social dos serviços públicos, São Paulo: Max Limonad, 1999, p. 125.

${ }^{338}$ Fernando Herren Aguillar, Controle social dos serviços públicos, p. 138.

${ }^{339}$ Cf. Fernando Herren Aguillar, Controle social dos serviços públicos, p. 139.

${ }^{340}$ Fernando Herren Aguillar, Controle social dos serviços públicos, p. 139.

${ }^{341}$ Fernando Herren Aguillar, Controle social dos serviços públicos, p. 152.

342 Regidos pelo regime do artigo 175 da Constituição.

${ }^{343}$ Regidos pelo regime do artigo 223 da Constituição (serviço de radiodifusão sonora e de sons e imagens).

${ }^{344}$ Cf. Floriano Peixoto Marques Neto, "Concessão de serviço público sem ônus para o usuário", in Luiz Guilherme da Costa Wagner Júnior, Direito Público - Estudos em homenagem ao Professor Adilson Abreu Dallari, Belo Horizonte, Del Rey, 2004, p. 334.

${ }^{345}$ Cf. Floriano Peixoto Marques Neto, "Concessão de serviço público sem ônus para o usuário”, p. 336.
} 
Celso Antônio Bandeira de Mello, de maneira parecida, apresenta uma classificação de serviços públicos, que inclui a atividade educacional. Para ele, de acordo com o regime constitucional estabelecido, os serviços públicos podem ser distinguidos pelas seguintes características: ${ }^{346}$ (a) serviços de prestação obrigatória e exclusiva do Estado ${ }^{347}$ (b) serviços de prestação obrigatória do Estado e em que também é obrigatório outorgar em concessão a terceiros; ${ }^{348}$ (c) serviços de prestação obrigatória pelo Estado, mas sem exclusividade; ${ }^{349}$ e (d) serviços de prestação não obrigatória pelo Estado, mas que, não os prestando, o obriga a promover-lhes a prestação, tendo, pois que outorgá-los em concessão ou permissão a terceiros. ${ }^{350}$

Nesse sentido, há outros autores que entendem que a atividade educacional, mesmo quando prestada por particular, se configura como serviço público. Eros Roberto Grau distingue serviços públicos privativos de serviços públicos não privativos: os primeiros são aqueles cuja prestação é privativa do Estado, ainda que se admita a possibilidade do setor privado desenvolvê-los, apenas em regime de concessão ou permissão, nos termos do artigo 175, da Constituição. Os serviços públicos não privativos, diferentemente, são aqueles que podem ser desenvolvidos pelo Estado, quanto pelo setor privado, ${ }^{351}$ tendo como exemplos típicos a prestação dos serviços de educação e saúde: ${ }^{352}$

"Seja como for, temos que serviços de educação e saúde, em qualquer hipótese, quer estejam sendo prestados pelo Estado, quer por particulares, configuram serviço público - serviço público não privativo, como vimos." 353

Magno Federici Gomes aponta que, apesar de não ser atividade exclusiva do Poder Público, a educação satisfaz uma pretensão coletiva, a ser desenvolvida com a colaboração mútua do Estado, segmento particular, sociedade e família, tratando-se, assim, de um serviço público em sentido amplo, ${ }^{354}$ permitindo sua prestação por autorizatários,

\footnotetext{
${ }^{346}$ Cf. Celso Antônio Bandeira de Mello, Curso de direito administrativo. 27. ed. São Paulo: Malheiros, 2010, p. 688-690.

${ }^{347}$ É o caso do serviço postal e correio aéreo nacional.

${ }^{348}$ É o caso da radiodifusão sonora ou de som e imagens.

${ }^{349}$ É o caso da educação, da saúde, da previdência social e da assistência social.

${ }^{350}$ É o caso de todos os demais.

${ }^{351}$ É importante ressaltar que o autor modificou seu entendimento anterior de que essas atividades teriam substrato de atividade econômica, e, portanto, constituiriam serviço público quando desenvolvidas pelo Estado, e atividade econômica em sentido estrito, quanto pelo setor privado.

${ }^{352}$ Cf. Eros Roberto Grau, A ordem econômica na Constituição de 1988, 14. ed., São Paulo: Malheiros, 2010, pp. 122-123.

${ }_{353}$ Eros Roberto Grau, A ordem econômica na Constituição de 1988, 14. ed., p. 123.

354 Cf. Magno Federici Gomes, "Educação superior privada como serviço de utilidade pública", Ensaio: Avaliação e Políticas Públicas em Educação (63) 2009, p. 272.
} 
que assumem o risco na atividade econômica e podem cobrar seus serviços dos usuários, desde que cumpram as condições previamente regulamentadas e se submetam ao controle exercido pela supervisão e avaliação dos órgãos competentes. ${ }^{355}$

Vitor Rhein Schirato entende que o que caracteriza o serviço público não é a prerrogativa estatal que interdita o exercício dessa atividade pelo particular, mas a existência de "uma obrigação estatal (em sentido jurídico), a qual, só de forma episódica e específica, poderá impor restrições ao direito fundamental de livre iniciativa, conforme venha a ser proporcional para a realização de um dado direito fundamental". ${ }^{356}$ Por essa visão, a educação, mesmo desenvolvida pelo particular, deve ser considerada serviço público, tendo em vista tratar-se de obrigação estatal, vinculada diretamente a direitos fundamentais e que, por essa razão, condiciona seu desenvolvimento pela iniciativa privada.

José Eduardo de Alvarenga entende que, dos serviços públicos arrolados na Constituição, nem todos são privativos do Estado, uma vez que a assistência à saúde e o ensino são livres à iniciativa privada. ${ }^{357}$ No entanto, o autor critica a utilização, pela Constituição, da expressão autorização, em sua opinião, incompatível com o regime jurídico público:

"Com efeito, as atividades dependentes de autorização não podem ser incluídas entre os serviços públicos. O equívoco do uso da expressão "autorização" quando se refere a serviços públicos, no texto constitucional, é patente: autorização" refere-se a atividades privadas que supõem, para seu exercício, prévia concordância do Poder Público. O objeto da autorização é facultar ao particular a prática de ato de seu interesse, não reservado ao Poder Público.”358

Marçal Justen Filho também aponta que a expressão autorização é incompatível com a existência de um serviço público:

"Não se outorga autorização de serviço público - fórmula verbal destituída de sentido lógicojurídico. Somente se cogita de autorização para certas atividades econômicas em sentido

\footnotetext{
${ }^{355}$ Cf. Magno Federici Gomes, "Educação superior privada como serviço de utilidade pública", p. 283.

${ }^{356}$ Vitor Rhein Schirato, Livre iniciativa nos serviços públicos, Belo Horizonte, Fórum, 2012, p. 328.

${ }^{357}$ Cf. José Eduardo de Alvarenga. "O serviço público", in José Eduardo Martins Cardozo / João Eduardo Lopes Queiroz / Márcia Walquíria Batista dos Santos (orgs.), Curso de Direito Administrativo Econômico. Vol I. São Paulo: Malheiros, 2006, p. 330.

358 José Eduardo de Alvarenga. "O serviço público", p. 337.
} 
estrito, cuja relevância subordina seu desempenho à fiscalização mais ampla e rigorosa do Estado. Sendo outorgada autorização não existirá serviço público.”359

O entendimento de que a atividade educacional é sempre serviço público foi expressa na Declaração da Conferência Regional de Educação Superior na América Latina e no Caribe, de 2008, preparatória da Conferência Mundial sobre Ensino Superior, em 2009:

"Considerando a imensa tarefa de expandir a cobertura que se apresenta para os países da América Latina e do Caribe, tanto o setor público quanto o privado estão obrigados a outorgar uma Educação Superior com qualidade e pertinência, razão pela qual os governos devem fortalecer os mecanismos de reconhecimento que garantam a transparência e a condição de serviço público." 360

Nessa linha, foi rejeitado o tratamento da educação como serviço comercial a ser disciplinado pelas regras da Organização Mundial do Comércio (OMC), por não se tratar de mercadoria:

"8 - A incorporação da Educação como um serviço comercial no marco da Organização Mundial de Comércio (OMC) foi sumariamente rejeitada por diversas organizações relacionadas diretamente com a Educação Superior."’361

O texto aprovado em 2009 na Conferência Mundial sobre Ensino Superior - As Novas Dinâmicas do Ensino Superior e Pesquisas para a Mudança e o Desenvolvimento Social - embora menos enfático do que o da declaração latino-americana, estabeleceu, em um de seus pontos, a educação como bem público, submetida, porém a financiamento público e privado:

“47. Financiamento: A educação é um bem público, porém financiamento privado deve ser estimulado. Enquanto todos os esforços devem ser tomados para aumentar o financiamento público do ensino superior, é necessário reconhecer que os financiamentos públicos são limitados e podem não ser suficientes para desenvolver o setor rapidamente. Outras fórmulas e fontes de financiamento devem ser encontradas, especialmente as baseadas no modelo de parceria público-privado."

Outro indicativo da natureza de serviço público da atividade educacional desenvolvida pela iniciativa privada é a equiparação dos de dirigentes de estabelecimentos

\footnotetext{
${ }^{359}$ Cf. Marçal Justen Filho, "Serviço público no direito brasileiro", in José Eduardo Martins Cardozo / João Eduardo Lopes Queiroz / Márcia Walquíria Batista dos Santos (orgs.), Curso de Direito Administrativo Econômico. Vol I. São Paulo: Malheiros, 2006, p. 386.

${ }^{360}$ Declaração da Conferência Regional de Educação Superior na América Latina e no Caribe, p. 237.

${ }^{361}$ Declaração da Conferência Regional de Educação Superior na América Latina e no Caribe, p. 238.
} 
particulares de ensino (quanto à matrícula e realização de provas, sobretudo) como ato de autoridade para fins de interposição de mandado de segurança, embora não exerçam função delegada, mas atividade dependente de autorização. ${ }^{362}$

A jurisprudência do Supremo Tribunal Federal, refletindo a controvérsia doutrinária, não é sistematizada no que diz respeito à delimitação do conceito de serviço público. $^{363}$ Quanto à natureza jurídica da atividade educacional desenvolvida por particulares, no julgamento da Ação Direta de Inconstitucionalidade no 319-4, que tinha por objeto a lei que dispunha sobre mensalidades escolares, o tribunal afirmou o caráter privado dos serviços prestados por tais estabelecimentos, mas, tendo em vista a ponderação entre os interesses públicos e privados envolvidos, considerou constitucional o controle de preços: ${ }^{364}$

"EMENTA: - Ação direta de inconstitucionalidade. Lei 8.039, de 30 de maio de 1990, que dispõe sobre critérios de reajuste das mensalidades escolares e da outras providencias. - Em face da atual Constituição, para conciliar o fundamento da livre iniciativa e do princípio da livre concorrência com os da defesa do consumidor e da redução das desigualdades sociais, em conformidade com os ditames da justiça social, pode o Estado, por via legislativa, regular a política de preços de bens e de serviços, abusivo que é o poder econômico que visa ao aumento arbitrário dos lucros. - Não é, pois, inconstitucional a Lei 8.039, de 30 de maio de 1990, pelo só fato de ela dispor sobre critérios de reajuste das mensalidades das escolas particulares."

No entanto, recentemente, vem se consolidando no Supremo Tribunal Federal a posição predominante de caracterizar a atividade educacional como serviço público mesmo quando desenvolvida pela iniciativa privada, conforme aponta Luiz Gustavo Bambini de Assis:

"Percebe-se, pois, que a questão tem sido objeto de atenção de nossa Suprema Corte e a tendência é do reconhecimento do direito à educação como sendo público e subjetivo. Por essa razão, não obstante ser prestado pela iniciativa privada, o serviço educacional, na sua essência, não perde as características do serviço público."365

Nesse diapasão, podemos apontar o acórdão proferido pelo Supremo Tribunal Federal no julgamento da Ação Direta de Inconstitucionalidade ${ }^{\circ}$ 1.266-5, relatada pelo Ministro Eros Grau:

${ }^{362}$ Cf. Odete Medauar, Direito administrativo moderno, 14. ed., São Paulo: RT, 2010, p. 423.

${ }^{363}$ Cf. Alexandre Santos de Aragão, Direito dos serviços públicos, p. 149.

${ }^{364}$ Cf. Alexandre Santos de Aragão, Direito dos serviços públicos, p. 182.

${ }^{365}$ Luiz Gustavo Bambini de Assis, "A natureza jurídica do serviço prestado pelas instituições privadas de ensino: controvérsias sobre o tema", in Nina Beatriz Stocco Ranieri (coord.), Direito à educação: aspectos constitucionais, São Paulo: EDUSP, 2009, p. 199. 
"EMENTA: AÇÃO DIRETA DE INCONSTITUCIONALIDADE. LEI N. 6.584/94 DO ESTADO DA BAHIA. ADOÇÃO DE MATERIAL ESCOLAR E LIVROS DIDÁTICOS PELOS ESTABELECIMENTOS PARTICULARES DE ENSINO. SERVIÇO PÚBLICO. VÍCIO FORMAL. INEXISTÊNCIA. 1. Os serviços de educação, seja os prestados pelo Estado, seja os prestados por particulares, configuram serviço público não privativo, podendo ser prestados pelo setor privado independentemente de concessão, permissão ou autorização. 2. Tratando-se de serviço público, incumbe às entidades educacionais particulares, na sua prestação, rigorosamente acatar as normas gerais de educação nacional e as dispostas pelo Estado-membro, no exercício de competência legislativa suplementar $\left(\$ 2^{\circ}\right.$ do ar. 24 da Constituição do Brasil). 3. Pedido de declaração de inconstitucionalidade julgado improcedente."

De todo exposto, percebe-se que a ambiguidade presente na definição de serviço público e a existência de um considerável número de regimes jurídicos diferenciados para o desenvolvimento de atividades econômicas em sentido estrito, não descritos de forma satisfatória nos artigos 173 e 175 da Constituição, refletem na caracterização da natureza jurídica da atividade educacional, acarretando a divergência doutrinária e jurisprudencial apresentada. No entanto, independentemente da caracterização da atividade educacional como serviço público ou atividade econômica em sentido estrito, resta pacificado o entendimento de que o desenvolvimento dessa atividade é submetido a um regime regulatório forte, com controle estatal muito mais rigoroso do que nas atividades econômicas em sentido estrito em geral, por conta de sua importância em relação aos objetivos de desenvolvimento de um país. ${ }^{366}$

Por essa razão, o presente trabalho acolhe o posicionamento de que a educação, mesmo quando desenvolvida por particulares, é serviço público, submetida a um regime jurídico que reflete suas peculiaridades constitucionalmente estabelecidas no artigo 209, não se submetendo, assim, aos dois principais regimes jurídicos descritas na Constituição: não se submete ao artigo 173 , tendo em vista o fato que sua prestação pelo Estado é constitucionalmente obrigatória, sem a existência de monopólio; tampouco está disciplinada pelo artigo 175 , por não estar sujeita a regime de delegação ao particular exclusivamente por concessão ou permissão. Essa visão só é possível com o entendimento de que o serviço público não está adstrito às disposições contidas no artigo 175, mas tem outros regimes constitucionalmente estabelecidos.

\footnotetext{
${ }^{366}$ Cf. Vladmir Oliveira da Silveira / Irene Patrícia Nohara, "Supervisão do ensino superior de direito no contexto federativo e complexidades do controle da pós-graduação stricto sensu”, p. 284.
} 
Assim sendo, a análise da atividade regulatória por parte do Estado, no campo da educação superior, deve considerar o fato de que se está diante da regulação da prestação de um serviço público fundamental para a efetivação de direitos sociais. ${ }^{367}$ Por outro lado, dada a peculiaridade de que o desenvolvimento da atividade educacional é livre à iniciativa privada, independentemente de concessão ou permissão, mas condicionada à avaliação de qualidade, incide em sua regulação alguns aspectos relativos à regulação das atividades econômicas em sentido estrito. ${ }^{368}$

\subsection{Fundamentos da atividade regulatória do Estado}

A regulação econômica é um assunto muito debatido pela doutrina jurídica brasileira desde a última década do século XX, de um lado, em relação à regulação da concorrencial, no campo das atividades econômicas em sentido estrito, e, principalmente, no que se refere à regulação econômica setorial, tendo em vista a mudança do modelo do Estado e do conceito de serviço público, cujos pressupostos econômicos, sociais e políticos alteraram-se radicalmente nas últimas décadas. ${ }^{369} \mathrm{Em}$ grande medida, essa doutrina desenvolveu-se com foco nos serviços públicos que eram prestados diretamente pelo Estado, principalmente nas décadas seguintes à Segunda Guerra Mundial, e que, nas últimas décadas do século XX, tiveram a sua prestação delegada à iniciativa privada. Essa mudança de paradigma na prestação de serviços públicos gerou a necessidade da criação de mecanismos jurídicos para a regulação da adequada prestação do serviço público pelo setor privado, ${ }^{370}$ envolvendo regras procedimentais e de organização - que no Brasil envolveu, em grande parte dos casos, a criação de agências reguladoras.

É nesse contexto que, segundo Eros Roberto Grau, a fim de servir de instrumento para a efetivação de políticas públicas, "deixa o direito de regular

\footnotetext{
${ }^{367}$ Nesse sentido, pode ser citada a atual legislação que trata das anuidades escolares: a Lei n ${ }^{\circ} 9.870$, de 23 de novembro de 1999.

${ }^{368}$ Nesse sentido, são aplicáveis às instituições privadas as disposições do Código de Defesa do Consumidor. Da mesma maneira, entendo que caberia a aplicação das normas relativas ao Sistema Brasileiro de Defesa da Concorrência - SBDC para operações de concentração econômica em relações societárias promovidas por mantenedoras de instituições de ensino superior.

${ }^{369}$ Cf. Dinorá Adelaide Musetti Grotti, "Teoria dos Serviços Públicos e sua Transformação", in Carlos Ari Sundfeld (coord.), Direito Administrativo Econômico. São Paulo: Malheiros, 2006, p. 43.

${ }_{370} \mathrm{Em}$ geral, foram delegados, por meio de concessão ou permissão, os serviços públicos regidos pelo artigo 175 da Constituição.
} 
exclusivamente situações estruturais, passando a ordenar situações conjunturais. Daí porque, neste momento, perece a concreção da lei como norma abstrata e geral". ${ }^{371}$

Patrícia Rodrigues Pessôa Valente aponta que, nos países em desenvolvimento como o Brasil, houve ao menos três categorias de regulação econômica nas últimas décadas: (a) a elaboração de uma estrutura regulatória aplicável aos setores privatizados da economia (telecomunicações e energia, por exemplo); (b) a mudança na intervenção estatal em alguns setores para atrair investimento privado (portos e aviação civil, por exemplo); e (c) o aperfeiçoamento da regulação em setores que exigem constante controle em razão de dever estatal constitucionalmente definido (saúde e meio ambiente, por exemplo). ${ }^{372}$ As duas primeiras categorias tiveram seu sistema de regulação sistematizado e estudado de forma extensa pela doutrina. Esse fenômeno se deve, em grande ao fato de que, em geral, tais sistemas regulatórios foram estruturados por meio da criação de agências reguladoras. A terceira categoria - caso da educação superior - ainda apresenta sistemas regulatórios em consolidação, merecendo, assim, atenção dos estudiosos do direito público.

Nessa linha, para Floriano de Azevedo Marques Neto, serviço público e regulação econômica são duas esferas jurídicas que passam por significativas mudanças nas últimas décadas, com a ampliação dos campos de atuação regulatória estatal e transformação da noção de serviço público, por meio da privatização de empresas e quebra do paradigma monopolista da exploração dessa atividade. ${ }^{373}$ Para ele é um equívoco acreditar que está em curso um processo de desregulação ou redução da regulação estatal, tendo em vista que esta se desenvolveu como uma das modalidades de intervenção estatal em face (no e sobre) do domínio econômico, assim definida:

"a atividade estatal mediante a qual o Estado, por meio de intervenção direta ou indireta, condiciona, restringe, normatiza ou incentiva a atividade econômica de modo a preservar a sua existência, assegurar o seu equilíbrio interno ou atingir determinados objetivos públicos como a proteção de hipossuficiências ou a consagração de políticas públicas." ${ }^{374}$

Esse quadro não é exatamente o existente na área da educação, uma vez que sua prestação pela iniciativa privada no Brasil já era consolidada, sob o regime de

\footnotetext{
${ }^{371}$ Eros Roberto Grau, O direito posto e o direito pressuposto, 8. ed., São Paulo: Malheiros, 2012, p. 119.

${ }^{372}$ Cf. Pessôa Valente, Patrícia Rodrigues. Análise de Impacto Regulatório: uma ferramenta à disposição do Estado. Dissertação de Mestrado. Departamento de Direito do Estado da Faculdade de Direito, Universidade de São Paulo, São Paulo, 2010, p. 7.

${ }^{373}$ Cf. Floriano de Azevedo Marques Neto, "A nova regulação dos serviços públicos", Revista de Direito Administrativo 228 (2002), p. 13

${ }^{374}$ Floriano de Azevedo Marques Neto, “A nova regulação dos serviços públicos”, p. 14.
} 
autorização. No entanto, a prestação do serviço de educação pela iniciativa privada, em especial no nível superior, teve significativo crescimento no período que coincidiu com a delegação da prestação de grande parte dos serviços públicos ao setor privado. Dessa forma, embora não tenha exatamente os mesmos pressupostos, a educação superior no Brasil também está submetida ao mesmo fenômeno: o do aumento da participação privada em sua prestação. Por essa razão, o estudo da doutrina relativa à regulação estatal da prestação dos serviços públicos mostra-se importante para a compreensão do regime jurídico específico da regulação da educação superior.

\subsubsection{Regulação: administração pública ordenadora e fomento}

Regulação, em seu aspecto jurídico, segundo Maria Sylvia Zanella di Pietro, é o "conjunto de regras de conduta e de controle da atividade privada do Estado, com a finalidade de estabelecer o funcionamento equilibrado do mercado". ${ }^{375}$ Para André Ramos Tavares, "a regulação é modalidade de intervenção estatal, classificada quanto ao seu conteúdo e sua forma. Caracteriza-se pela imposição, por meio de lei, de determinações acerca do desenvolvimento de atividades econômicas visando ao interesse público.”376 Para Marçal Justen Filho, "a regulação consiste no conjunto de providências por meio das quais o Estado busca disciplinar o desempenho pela iniciativa privada de atividades de interesse coletivo."377

Nota-se das conceituações expostas os seguintes elementos: uma atuação estatal, que disciplina atividades privadas, para alcançar determinada finalidade. No entanto, esses elementos - presentes também na tradicional noção de poder de polícia não bastam para caracterização do conceito de regulação, que é mais amplo do que o daquele, abrangendo também outras formas de intervenção estatal.

No entanto, mais adequado à realidade contemporânea é o conceito apresentado por Carlos Ari Sundfeld a respeito da atividade de regulação administrativa da vida privada: a administração ordenadora, que supera a ideia de poder de polícia, típica do

\footnotetext{
${ }^{375}$ Maria Sylvia Zanella di Pietro, "Limites da função reguladora das Agencias diante do princípio da legalidade", in Direito regulatório: temas polêmicos, Maria Silvia Zanella di Pietro (org.), São Paulo: Fórum, 2003, p. 29.

${ }^{376}$ André Ramos Tavares, "A intervenção do Estado no domínio econômico", in José Eduardo Martins Cardozo / João Eduardo Lopes Queiroz / Márcia Walquíria Batista dos Santos (orgs.), Curso de Direito Administrativo Econômico. Vol II. São Paulo: Malheiros, 2006, 173-218. 181

${ }^{377}$ Marçal Justen Filho, Curso de Direito Administrativo, p. 99.
} 
Estado Liberal. ${ }^{378}$ Esse conceito é inspirado na doutrina alemã que distingue a administração ordenadora (Ordnungsvervaltung ou ordnenden Verwaltung) em contraposição à que presta serviços ao administrado (Leistungsverwaltung ou leistenden Verwaltung), que o autor prefere denominar administração prestacional. ${ }^{379}$ Segundo o autor, administração ordenadora se apresenta como aquela que "congrega as operações estatais de regulação do setor privado (e, portanto, ligadas à aquisição, exercício e sacrifício de direitos privados), com o emprego do poder de autoridade", ${ }^{380}$ assim definida:

"Administração ordenadora é a parcela da função administrativa desenvolvida com o uso do poder de autoridade, para disciplinar, nos termos e para os fins da lei, os comportamentos dos particulares no campo de atividades que lhes é próprio." ${ }^{381}$

A função administrativa regulatória, portanto, apesar de utilizar permanentemente as competências inerentes à administração ordenadora, é exercida de forma mais abrangente, pois compreende poderes para disciplinar setores econômicos, dispondo sobre a conduta individual e coletiva, podendo utilizar medidas jurídicas permitivas e proibitivas, mas também mecanismos de incentivo e desincentivo. ${ }^{382}$ Desta maneira, a regulação também compreende a atividade administrativa de fomento, assim definido por Marçal Justen Filho:

"Fomento é uma atividade administrativa de intervenção no domínio econômico para incentivar condutas dos sujeitos privados mediante a outorga de benefícios diferenciados, inclusive mediante a aplicação dos recursos financeiros, visando a promover o desenvolvimento econômico e social." ${ }^{383}$

A atividade regulatória, portanto, implica na integração de diversas funções, conforme aponta Alexandre Santos de Aragão:

"Este quadro normativo é estabelecido por decisões gerais e abstratas, constantes geralmente de regulamentos; pela aplicação concreta das suas regras; pela composição dos conflitos que delas advêm, dando lugar, nestas duas últimas hipóteses, a decisões individuais. Há, portanto,

\footnotetext{
${ }^{378}$ Cf. Carlos Ari Sundfeld, Direito Administrativo Ordenador, São Paulo: Malheiros, 1993, pp. 13-15.

${ }^{379}$ Cf. Carlos Ari Sundfeld, Direito Administrativo Ordenador, p. 16.

${ }^{380}$ Carlos Ari Sundfeld, Direito Administrativo Ordenador, pp. 16-17.

${ }^{381}$ Carlos Ari Sundfeld, Direito Administrativo Ordenador, p. 20.

${ }^{382}$ Cf. Marçal Justen Filho, Curso de Direito Administrativo, 8. ed., Belo Horizonte: Fórum, 2012, pp. 98-99.

${ }^{383}$ Marçal Justen Filho, Curso de Direito Administrativo, p. 677.
} 
três poderes inerentes à regulação: aquele de editar a regra, o de assegurar sua aplicação e o de reprimir infrações. ${ }^{384}$

Para Maria Sylvia Zanella di Pietro, a atividade da Administração Pública abrange fundamentalmente o fomento, a polícia administrativa e o serviço público. ${ }^{385}$ Essas três noções, tradicionalmente tratadas de forma separada pelo Direito Administrativo, encontram-se presentes simultaneamente, conforme visto, na noção de regulação de serviços públicos, demonstrando o quão complexas se apresentam para o tratamento por meio da doutrina tradicional dessa disciplina. É por essa razão que a regulação é apontada como uma forma autônoma de atividade administrativa.

\subsubsection{Regulação econômica e regulação social}

Como mencionado, o conceito de regulação econômica, assim como o de serviço público, sofreram mudanças significativas nas últimas décadas, e não apresentam tratamento uniforme por parte da doutrina e da jurisprudência. ${ }^{386}$ Em relação a esta, Diogo de Sant'Ana apresenta diferentes acepções de regulação encontradas em julgados do Supremo Tribunal Federal: o Ministro Joaquim Barbosa, ${ }^{387}$ utiliza o termo no sentido de organização da atividade econômica; o Ministro Moreira Alves, ${ }^{388}$ na utilizou no sentido de controle; o Ministro Célio Borja, ${ }^{389}$ apresenta normatividade regulatória como uma espécie de normatividade específica, própria da administração. ${ }^{390} \mathrm{O}$ elemento comum, segundo o autor, é que regulação constitui-se em uma atividade (atuação ou intervenção), com uma finalidade (organização da economia). ${ }^{391}$

Apesar da ambiguidade do termo regulação, pode-se apontar que ele é atualmente utilizado, principalmente, com dois sentidos, conforme aponta Eros Roberto Grau: a regulação da atividade econômica em sentido estrito (regulação do Estado sobre o domínio econômico) e a regulação de serviços públicos, que se tornou muito importante a

\footnotetext{
384 Alexandre Santos de Aragão, "Regulação da Economia: conceito e características contemporâneas", in José Eduardo Martins Cardozo / João Eduardo Lopes Queiroz / Márcia Walquíria Batista dos Santos (orgs.). Curso de Direito Administrativo Econômico. Vol III. São Paulo: Malheiros, 2006, p. 418.

${ }^{385}$ Cf. Maria Sylvia Zanella di Pietro, Direito administrativo, p. 55.

${ }^{386}$ Cf. 3.1 .

${ }^{387}$ Recurso Extraordinário no 422.941.

${ }^{388}$ Ação Direta de Inconstitucionalidade no 319

${ }^{389}$ Conflito de Atribuições no 35.

${ }^{390}$ Cf. Diogo de Sant"Ana, "Conjuntura da regulação no Brasil: conflitos e convergência”, in Mario Gomes Schapiro (coord.), Direito econômico regulatório, São Paulo: Saraiva, 2010, p. 367-368.

${ }^{391}$ Cf. Diogo de Sant ${ }^{e ` A n a, ~ " C o n j u n t u r a ~ d a ~ r e g u l a c ̧ a ̃ o ~ n o ~ B r a s i l ”, ~ p . ~} 368$.
} 
partir do fenômeno da privatização destes. ${ }^{392}$ De todo modo, por tratarem ambas as acepções de regulação de atividades econômicas em sentido amplo, de forma genérica tais formas de regulação podem ser denominadas de regulação econômica.

Para Vital Moreira, regulação econômica é “o estabelecimento e a implementação de regras para a actividade económica destinadas a garantir o seu funcionamento equilibrado, de acordo com determinados objetivos públicos", 393 consubstanciando-se sempre em um condicionamento externo à atividade dos agentes econômicos, não incluindo a atividade econômica do próprio Estado. ${ }^{394}$ Por essa visão, o condicionamento estatal sobre a educação superior desempenhada por meio de instituições educacionais públicas, não poderia ser considerada como regulação.

Em linhas gerais, Floriano de Azevedo Marques Neto aponta que se verifica uma forte redução na intervenção direta estatal, ocorrendo o engrandecimento e reestruturação da regulação estatal sobre determinados setores, com o surgimento de um novo padrão de atuação regulatória:

"onde a imposição unilateral e autoritária de pautas, condutas e comportamentos dá lugar à articulação de interesses e ao estabelecimento de pautas regulatórias negociadas com os diversos interesses envolvidos numa dada atividade (operadores, usuários efetivos e usuários potenciais). ${ }^{395}$

Trata-se do fenômeno que o autor denomina regulação reflexiva, por meio da qual "o Estado deixa de ser um adjudicador de direitos e passa a ser um mediador de interesses, sem perder a função de tutor das hipossuficiências sociais" 396 Surge, assim, a necessidade de maior interlocução com a sociedade, com o Estado assumindo papel de mediador ativo de interesses, a fim de se consolidar uma atividade regulatória permeável à participação da sociedade. ${ }^{397}$ Essa pesquisa buscará compreender em que medida esse fenômeno ocorre com a regulação da educação superior.

Nessa visão, a noção de atividade regulatória - na perspectiva de mediação ativa de interesses - envolve uma dupla atividade estatal: (a) arbitrar interesses de atores

\footnotetext{
392 Cf. Eros Roberto Grau, "Atividade econômica e regulação", Revista da Academia Brasileira de Direito Constitucional 3 (2003), p. 446.

${ }^{393}$ Vital Moreira, Auto-regulação profissional e Administração Pública, Coimbra: Almedina, 1997, p. 34.

${ }^{394}$ Cf. Vital Moreira, Auto-regulação profissional e Administração Pública, p. 37.

${ }^{395}$ Floriano de Azevedo Marques Neto, “A nova regulação dos serviços públicos”, p. 15.

${ }^{396}$ Floriano de Azevedo Marques Neto, "A nova regulação dos serviços públicos”, p. 16.

${ }^{397}$ Cf. Floriano de Azevedo Marques Neto, “A nova regulação dos serviços públicos”, pp. 16-17.
} 
sociais e econômicos fortes; e (b) induzir ou coordenar as atividades em cada segmento específico, uma vez que se observa o surgimento de subsistemas jurídicos dotados de grande especialidade, com princípios, conceitos, pressupostos e procedimentos próprios. ${ }^{398}$

Por outro lado, Gilberto Bercovici aponta que, com a reforma do Estado, a regulação passou a ocorrer de dois modos distintos:

“a regulação contratual, ou seja, por meio do contrato de concessão entre o órgão regulador e o particular prestador do serviço público; e a regulação econômica setorial (economic regulation), pelo controle e fiscalização da prestação do serviço desempenhada pela atuação da "agência" reguladora do setor.",399

Segundo o autor, para desempenhar a função regulatória "o Estado deve gozar de autonomia perante os grupos sociais, alargando suas funções e readaptando seus órgãos e estruturas. ${ }{ }^{400}$ Para garantir a autonomia regulatória do Estado, é necessário evitar o risco da ocorrência da captura do regulador.

De acordo com o exposto, procedimento regulatório e sua estrutura administrativa devem ser estabelecidos com a constituição de instrumentos de efetivação de uma regulação reflexiva, por meio de uma adequada interlocução com os atores setoriais, garantindo-se, no entanto, um adequado grau de autonomia em relação aos grupos sociais, a fim de se evitar o fenômeno da captura do agente regulador. ${ }^{401}$

Existem muitas críticas à teoria da regulação, pelo fato de terem como fundamento a atividade econômica em si, por meio da tentativa de regular as falhas de mercado, relegando a segundo plano os aspectos sociais. Para Eros Grau, a teoria da regulação camufla os conflitos sociais, na medida em que "supõe que todos os homens sejam prudentes, supõe a inexistência dos fenômenos de dominação social, pretende substituir a função reguladora do Estado - que é a exoregulação - pela autoregulação". ${ }^{402}$

\footnotetext{
${ }^{398}$ Cf. Floriano de Azevedo Marques Neto, “A nova regulação dos serviços públicos”, p. 17.

${ }^{399}$ Gilberto Bercovici, Constituição econômica e desenvolvimento: uma leitura a partir da Constituição de 1988, São Paulo: Malheiros, 2005, p. 83.

${ }^{400}$ Gilberto Bercovici, Constituição econômica e desenvolvimento, p. 69.

401 A captura do regulador "ocorre quando os organismos regulatórios se encontram muito próximos dos regulados, favorecendo o aumento dos riscos de interferência de interesses particulares nas decisões públicas, consequentemente afetando a independência e a qualidade da regulação" (Cf. Verônica Cruz, "Estado e regulação: fundamentos teóricos", in Pedro Ivo Sebba Ramalho (coord.), Regulação e Agências Reguladoras: governança e análise de impacto regulatório, Brasília: Anvisa, 2009, p. 62).

${ }^{402}$ Cf. Eros Roberto Grau, "Atividade econômica e regulação”, p. 450.
} 
Nessa linha de pensamento, Gilberto Bercovici e Luis Fernando Massonetto, criticam o modismo do tratamento jurídico da regulação econômica, ${ }^{403}$ fazendo emergir "uma disciplina estéril, despida de qualquer potencial crítico, capaz de legitimar o padrão de dominação hegemônico no sistema mundial, mas incapaz de oferecer alternativas à dependência das nações periféricas." ${ }^{404}$ Segundo os autores, "a crítica ao discurso regulatório passa, necessariamente, pela contextualização teórica e política das razões econômicas existentes por trás de tais reformas institucionais." ${ }^{405}$

No entanto, existe por parte da doutrina um tratamento da regulação que aborda seu aspecto social, fundamental para o desenvolvimento do país de acordo com os objetivos estabelecidos na Constituição. Marçal Justen Filho apresenta um conceito geral de regulação econômico-social, que abrangeria fenômenos que ele denomina de regulação exclusivamente econômica e regulação social, que enfatizam, também, a presença da ação estatal para se atingir uma finalidade relativa a políticas públicas relacionadas de alguma maneira com os direitos fundamentais:

“A regulação econômico-social consiste na atividade estatal de intervenção direta sobre a conduta dos sujeitos públicos e privados, de modo permanente e sistemático, para implementar as políticas de governo e a realização dos direitos fundamentais." ${ }^{406}$

Para esse autor, em um primeiro momento, que ele denomina de primeira "onda regulatória", houve preocupação com o tratamento da regulação exclusivamente econômica, ou seja, destinada exclusivamente a suprir as deficiências e as insuficiências do mercado: $:^{407}$

"Essas concepções foram objeto de intensa revisão, a propósito do que se poderia identificar como uma segunda onda intervencionista. Trata-se da regulação social, que assume outras propostas. Constatou-se que o mercado, ainda que em funcionamento perfeito, pode conduzir à não realização de certos fins de interesse comum." ${ }^{408}$

Vital Moreira também traz uma importante classificação da regulação, baseada na doutrina norte-americana, que aponta a distinção entre regulação econômica e

\footnotetext{
${ }^{403}$ Cf. Gilberto Bercovici / Luís Fernando Massonetto, "Limites da regulação: esboço para uma crítica metodológica do "novo direito público da economia", Revista de Direito Público da Economia 25 (2009), p. 138.

${ }^{404}$ Gilberto Bercovici / Luís Fernando Massonetto, "Limites da regulação", p. 140.

${ }^{405}$ Gilberto Bercovici / Luís Fernando Massonetto, "Limites da regulação", p. 142.

${ }^{406}$ Marçal Justen Filho, Curso de Direito Administrativo, p. 637.

${ }^{407}$ Cf. Marçal Justen Filho, Curso de Direito Administrativo, p. 658.

${ }^{408}$ Marçal Justen Filho, Curso de Direito Administrativo, p. 660.
} 
regulação social. ${ }^{409}$ A regulação econômica, propriamente dita, "tem por objecto e justificação a regulação dessa actividade em si (entrada na actividade, mercados e preços, quantidade e natureza dos produtos, etc.)", ${ }^{410}$ enquanto a regulação social "tem finalidades exteriores à actividade económica, como a protecção ambiental, a segurança e outros interesses dos consumidores". ${ }^{411}$ A doutrina americana considera a primeira como regulação tradicional (old style regulation), e a segunda como regulação moderna (modern style regulation). ${ }^{412}$ Por essa distinção, a regulação da educação superior se relaciona com a denominada regulação moderna, já que tem finalidades externas além da relação educacional em si, uma vez que guarda relação direta com o desenvolvimento do país e com a efetivação de direitos fundamentais.

Diante do analisado, pode-se concluir que a regulação da educação superior pode se valer de contribuições teóricas provenientes da teoria da regulação, mas tendo em vista seu caráter econômico-social, deve se direcionar não para o estabelecimento de um equilíbrio econômico em seu sistema, mas servir como instrumento para fomentar atividades que busquem, por meio do atingimento de metas estabelecidas no Plano Nacional de Educação, a efetivação do direito à educação, fundamental para o desenvolvimento nacional.

\subsection{Análise de impacto regulatório - AIR}

A fim de mensurar a efetividade da atividade regulatória, passou-se a desenvolver estudos sistemáticos que vieram a constituir o que se denomina análise de impacto regulatório - AIR: uma ferramenta que busca avaliar os efeitos da regulação, a fim de ordenar a atuação estatal buscando a adoção de procedimentos que propiciem uma regulação de melhor qualidade. ${ }^{413}$ Trata-se de uma ferramenta a ser desenvolvida primordialmente pelos agentes reguladores do Estado, a fim de orientar sua decisão regulatória, ainda que a análise de impacto regulatório compreenda ampla participação da sociedade civil e de agentes privados em geral. ${ }^{414}$

\footnotetext{
${ }^{409}$ Cf. Vital Moreira, Auto-regulação profissional e Administração Pública, p. 39.

${ }^{410}$ Vital Moreira, Auto-regulação profissional e Administração Pública, p. 39.

${ }^{411}$ Vital Moreira, Auto-regulação profissional e Administração Pública, p. 39.

412 Cf. Vital Moreira, Auto-regulação profissional e Administração Pública, p. 39.

${ }^{413}$ Cf. Patrícia Rodrigues Pessôa Valente, Análise de Impacto Regulatório, p. 8.

${ }^{414}$ Cf. Patrícia Rodrigues Pessôa Valente, Análise de Impacto Regulatório, p. 14.
} 
A adoção da análise de impacto regulatório é uma recomendação de organismos internacionais como o Banco Mundial e a OCDE, que assim recomenda sua adoção:

"A AIR é uma ferramenta regulatória que examina e avalia os prováveis benefícios, custos e efeitos das regulações novas ou alteradas. Ela oferece aos tomadores de decisão dados empíricos valiosos e uma estrutura abrangente na qual eles podem avaliar suas opções e as conseqüências que suas decisões podem ter. Um escasso entendimento dos problemas em questão ou dos efeitos indiretos da ação governamental pode debilitar os incentivos regulatórios e resultar em falha regulatória. A AIR é utilizada para definir problemas e garantir que a ação governamental seja justificada e apropriada." ${ }^{\$ 15}$

Patrícia Rodrigues Pessôa Valente, em um dos primeiros estudos sistematizados sobre análise de impacto regulatório no Brasil, conceitua essa ferramenta como:

"instrumento de controle da atividade regulatória do Estado por meio de aplicação de procedimento administrativo voltado à análise das decisões regulatórias a serem tomadas ou já tomadas pelos agentes reguladores com base em evidências empíricas, resultando na introdução no processo de tomada de decisão de mecanismos de legitimação democrática e de responsabilização do regulador." ${ }^{416}$

A implementação da análise de impacto regulatório busca a consolidação do equilíbrio democrático, por meio da transparência nos procedimentos e da consequente possibilidade de responsabilização (accountability) dos agentes reguladores. ${ }^{417} \mathrm{~A}$ análise de impacto regulatório se configura como requisito prévio necessário à implantação de qualquer inovação relevante na regulação setorial e sua ausência revela a carência de planejamento sobre as finalidades buscadas, transformando a atividade regulatória em mera decisão subjetiva, desvinculada de fundamentos técnico-científicos. ${ }^{418}$

Por se constituir um procedimento ordenado de tomada de decisão no âmbito da atividade regulatória do Estado, ${ }^{419}$ como expressão da política regulatória contida dentro

415 OCDE, Brasil: fortalecendo a governança para o crescimento, Relatório sobre a reforma regulatória, Casa Civil da Presidência da República, 2008, p. 62.

${ }_{417}^{416}$ Cf. Patrícia Rodrigues Pessôa Valente, Análise de Impacto Regulatório, p. 89.

${ }^{417}$ Cf. Patrícia Rodrigues Pessôa Valente, Análise de Impacto Regulatório, p. 138. Nesse sentido, vide Marcos Vinícius Pó / Fernando Luiz Abrúcio, "Desenho e funcionamento dos mecanismos de controle e accountability das agências reguladoras brasileiras: semelhanças e diferenças", Revista Brasileira de Administração Pública 40 (2006), pp. 685-686.

${ }^{418}$ Marçal Justen Filho, Curso de Direito Administrativo, pp. 645-646.

${ }^{419}$ Cf. Patrícia Rodrigues Pessôa Valente, Análise de Impacto Regulatório, p. 24. 
dos parâmetros definidos pela política pública, ${ }^{420}$ a análise de impacto regulatório deve ser incorporada na disciplina jurídica de cada procedimento administrativo regulatório específico.

Alexandre Santos de Aragão apresenta três pressupostos para a análise da avaliação de impacto regulatório. O primeiro é a necessidade de coordenação entre as diversas instâncias regulatórias, a fim de evitar consequências indesejáveis como, por exemplo, a insegurança jurídica; o segundo é a manutenção da independência de cada instância regulatória setorial; o terceiro é a necessidade da inclusão de todas as instâncias regulatórias, não só apenas as que se organizam como agências independentes. ${ }^{421} \mathrm{O}$ próprio autor entende que, dos pressupostos apontados, potencialmente colidentes entre si, surge a necessidade de conciliação entre a coordenação e a manutenção da independência. ${ }^{422}$ Para tanto, o autor aponta que uma solução possível seria "uma ideia de soft law, de o órgão das AIR tentar se impor voluntariamente, por meio de consensos, às entidades reguladoras". ${ }^{423}$ De certa maneira, essa foi a intenção da criação do Programa de Fortalecimento da Capacidade Institucional para Gestão em Regulação - PRO-REG.

\subsubsection{Programa de Fortalecimento da Capacidade Institucional para Gestão em Regulação - PRO-REG}

O Programa de Fortalecimento da Capacidade Institucional para Gestão em Regulação - PRO-REG foi criado pelo Decreto no 6.062, de 16 de março de 2007, com o intuito de fortalecer a atividade regulatória exercida pelo Governo Federal, contribuindo para a melhoria do sistema regulatório, da coordenação entre as instituições que participam do processo regulatório, dos mecanismos de prestação de contas e de participação e monitoramento por parte da sociedade civil e da qualidade da regulação de mercado. ${ }^{424} \mathrm{O}$ PRO-REG tem como objetivo fundamental a formulação e implementação de medidas integradas que, em síntese, objetivam o fortalecimento do sistema regulatório, pelo fortalecimento da capacidade de formulação e análise de políticas públicas dos setores regulados e desenvolvimento de mecanismos de accountability nos processos

\footnotetext{
${ }^{420}$ Cf. Patrícia Rodrigues Pessôa Valente, Análise de Impacto Regulatório, p. 74.

${ }^{421}$ Cf. Alexandre Santos de Aragão, "Análise de Impacto Regulatório - AIR", Revista de Direito Público da Economia 32 (2010), pp. 11-12.

${ }_{422}$ Cf. Alexandre Santos de Aragão, “Análise de Impacto Regulatório - AIR”, p. 13.

423 Alexandre Santos de Aragão, “Análise de Impacto Regulatório - AIR”, p. 14.

${ }^{424}$ Decreto $^{\circ}{ }^{6} 6.062 / 2007$, artigo $1^{\circ}$.
} 
regulatórios, ${ }^{425} \mathrm{E}$, por essa razão, é identificado "como uma iniciativa voltada à consolidação do arranjo regulatório adotado pelo Brasil na década de 1990". ${ }^{426}$ O programa parte do pressuposto que há aspectos comuns relativos à atividade regulatória dos diferentes setores, que precisam ser desenvolvidos a fim de que sejam implementadas políticas e procedimentos regulatórios decorrentes de um lastro conceitual, teórico e prático, comum.

Para alcançar tais objetivos, foram constituídos dois comitês: o Comitê Gestor do PRO-REG - CGP e o Comitê Consultivo do PRO-REG - CCP, que desenvolvem suas atividades com o apoio da Subchefia de Análise e Acompanhamento de Políticas Governamentais, sendo todos esses órgãos integrantes da Casa Civil da Presidência da República. $^{427}$

O Comitê Gestor é composto por um representante titular e um suplente, da Casa Civil da Presidência da República - que o coordenará, do Ministério da Fazenda e do Ministério do Planejamento, Orçamento e Gestão, e tem a competência de definir o direcionamento estratégico do PRO-REG; definir as prioridades, coordenar e supervisionar o andamento geral do PRO-REG e de seus componentes; articular os órgãos envolvidos com a operação; aprovar os planos de aquisições e programas operacionais anuais; aprovar os informes semestrais de avanço que deverão ser apresentados ao Banco Interamericano de Desenvolvimento - BID; e resolver aspectos controversos relacionados à execução do PRO-REG. ${ }^{428}$

O Comitê Consultivo é composto por um representante titular e um suplente, de cada uma das agências reguladoras referidas em anexo à Lei no 10.871, de 20 de maio de 2004, e dos Ministérios aos quais estão vinculadas, do Ministério da Justiça e do Conselho Administrativo de Defesa Econômica (CADE), e tem a competência de

\footnotetext{
${ }^{425}$ Decreto no $^{\circ} 6.062 / 2007$, art. $2^{\text {o: }}$

“Art. 2 $2^{\circ}$ O PRO-REG deverá contemplar a formulação e implementação de medidas integradas que objetivem:

I - fortalecer o sistema regulatório de modo a facilitar o pleno exercício de funções por parte de todos os atores;

II - fortalecer a capacidade de formulação e análise de políticas públicas em setores regulados;

III - a melhoria da coordenação e do alinhamento estratégico entre políticas setoriais e processo regulatório;

IV - o fortalecimento da autonomia, transparência e desempenho das agências reguladoras; e

$\mathrm{V}$ - o desenvolvimento e aperfeiçoamento de mecanismos para o exercício do controle social e transparência no âmbito do processo regulatório.”

${ }^{426}$ Patrícia Rodrigues Pessôa Valente, Análise de Impacto Regulatório, p. 162.

${ }^{427}$ Decreto $^{\circ}{ }^{6} 6.062 / 2007, \operatorname{artigos} 3^{\circ}, 4^{\circ}$ e 11 .

${ }^{428}$ Decreto $^{\circ} 6.062 / 2007$, artigos $5^{\circ}$ e $6^{\circ}$.
} 
apresentar e discutir propostas que possam apoiar e melhorar a execução do PRO-REG; colaborar para o aperfeiçoamento dos níveis técnicos das ações implementadas e contribuir para a sua efetividade; prestar assessoria e orientação ao CGP; e zelar pela integridade técnica do PRO-REG. ${ }^{429}$

A composição do Conselho Gestor - restrita a participação de ministériosmeio, é alvo de críticas, pelo fato de potencialmente restringir a autonomia dos entes reguladores. Em relação a esse ponto, há a permissão, pelo Decreto, de que a Casa Civil venha a convidar representantes de órgãos e entidades públicas e privadas, bem como de outros poderes institucionais, para participar das reuniões, porém, sem direito a voto. ${ }^{430}$ De qualquer maneira, essa estruturação orgânica pode vir a elevar o grau da forte resistência que em relação a esse órgão por parte das agências reguladoras, por identificá-lo como uma forma de controle adicional voltada a tolher sua independência. ${ }^{431}$

De fato, tendo em vista a estrutura de seus comitês, o PRO-REG apresenta possibilidade limitada da participação da sociedade civil, bem como de outras autoridades públicas dotadas de competências regulatórias, mas que por não serem classificadas como agências reguladoras, não têm participação nesse órgão. Nesse sentido, podem ser citados o Banco Central, o Instituto Brasileiro do Meio Ambiente - IBAMA, a Comissão de Valores Mobiliários - CVM, o Instituto Nacional de Metrologia, Normalização e Qualidade Industrial - INMETRO, ${ }^{432}$ bem como os órgãos que realizam a regulação da educação superior no Brasil.

A criação do PRO-REG vem a atender a recomendações da OCDE, que, no entanto, aponta para a necessidade melhoria de seus mecanismos de consulta e participação popular, bem como de sua ampliação para outras esferas da administração pública:

“O PRO-REG deve refletir essa tendência se desejar tornar-se um instrumento para expandir as habilidades de gestão regulatória por meio de da administração. Ainda que essa iniciativa se concentre em agências regulatórias, existe a necessidade de aumentar o escopo das instituições envolvidas. Não deveria haver justificativa alguma para que sejam feitas exceções em diferentes áreas políticas e instituições, após a acumulação de experiência. Se o PRO-REG pretende, por exemplo, melhorar os mecanismos de consulta e promover o uso compulsório de

\footnotetext{
${ }^{429}$ Decreto $^{\circ}$ 6.062/2007, artigos $8^{\circ}$ e $9^{\circ}$.

${ }^{430}$ Cf. Patrícia Rodrigues Pessôa Valente, Análise de Impacto Regulatório, p. 178.

${ }^{431}$ Cf. Alketa Peci, "Desenho de uma estratégia de implantação e institucionalização da AIR", in Jadir Dias Proença (org.), PRO-REG: Contribuições para melhoria da qualidade da Regulação no Brasil, vol 1, Brasília: Semear Editora/Presidência da República, 2010, p. 73.

${ }^{432}$ Cf. Patrícia Rodrigues Pessôa Valente, Análise de Impacto Regulatório, pp. 178-179.
} 
avaliação de impactos para alguns setores e agências, isso deveria evoluir com o tempo e ser aplicado em seu devido tempo a toda a administração pública e não somente para agências setoriais." ${ }^{, 433}$

A OCDE, dessa maneira, indica que a análise de impacto regulatório deve ser utilizada e consolidada pelo aparato estatal regulatório como um todo:

"Há uma necessidade de o Brasil obrigar a utilização da AIR, uma vez consolidada, de forma compulsória para todos os órgãos institucionais do Poder Executivo dotados de poderes regulatórios. A AIR é um instrumento que só poderá fazer alguma diferença se for levado a cabo de forma abrangente." ${ }^{434}$

No entanto, apesar da análise de impacto regulatório ser indicada para todas as esferas regulatórias, a composição e a atuação do PRO-REG abrange apenas as políticas regulatórias relativas à infraestrutura, aos serviços públicos delegados a particulares, desenvolvidas por meio de agências reguladoras, e à defesa da concorrência. O PRO-REG, dessa maneira, perde a oportunidade de consolidar uma política regulatória mais ampla em relação às peculiaridades setoriais, que poderia consistir em uma importante ferramenta para o desenvolvimento nacional. Não haveria porque outros órgãos e entidades que realizam regulação estatal - inclusive de outros entes da Federação - não participassem do PRO-REG, a fim de aperfeiçoar o instrumento da análise de impacto regulatório, por meio da integração de tais instituições. É o caso da regulação da educação superior.

\subsubsection{Análise de impacto regulatório na educacional superior}

De certa forma, o sistema de regulação da educação superior já apresenta elementos que podem servir como insumos para a realização de avaliação de impacto regulatório. Nesse sentido, os indicadores de qualidade, ${ }^{435}$ analisados individualmente (por curso ou instituição) ou globalmente, mostram-se úteis para a implementação da cultura da avaliação regulatória.

Recentemente, a fim de formular uma política regulatória para a educação superior, foi editada pelo Ministério da Educação a Portaria $n^{\circ} 1.006$, de 10 de agosto de 2012, que instituiu o Programa de Aperfeiçoamento dos Processos de Regulação e Supervisão da Educação Superior - PARES. Esse programa visa a formular e implementar

\footnotetext{
${ }^{433}$ OCDE, Brasil: fortalecendo a governança para o crescimento, p. 339.

${ }^{434}$ OCDE, Brasil: fortalecendo a governança para o crescimento, p. 342.

${ }^{435}$ Cf. 5.5.1.4.
} 
de medidas integradas que objetivem: (a) melhorar a eficiência e a efetividade das atividades de regulação e supervisão de cursos e instituições de educação superior, de forma a assegurar ao estudante, destinatário principal das políticas públicas educacionais, a oferta de uma educação superior de qualidade; (b) fortalecer a capacidade institucional para gestão em regulação e supervisão; (c) melhorar a coordenação e o alinhamento estratégicos entre as políticas públicas setoriais e os processos regulatórios; (d) aperfeiçoar e desenvolver mecanismos de controle social e transparência dos procedimentos de regulação e supervisão desenvolvidos pelo MEC; (e) e aprimorar e desenvolver mecanismos de atendimento de demanda da sociedade e dos agentes regulados pelas informações produzidas e gerenciadas pelo MEC. ${ }^{436}$

Nota-se de suas finalidades, bem como de seus objetivos específicos, ${ }^{437}$ uma semelhança muito grande com aqueles do PRO-REG, acrescido, no entanto, de uma maior preocupação com a participação do setor regulado e da sociedade em geral. Essa tendência pode ser percebida pela composição de seu órgão colegiado consultivo, o Conselho Consultivo do Programa de Aperfeiçoamento dos Processos de Regulação e Supervisão da Educação Superior - CC-PARES, ${ }^{438}$ que prevê em sua composição representantes de

${ }^{436}$ Portaria $^{\circ} 1.006 / 2012$, artigo $2^{\circ}$.

${ }^{437}$ Portaria $^{\circ}{ }^{1.006 / 2012}$, artigo $3^{\circ}$ :

"Art. $3^{\circ}$ São objetivos específicos do PARES:

I - aprimorar os instrumentos normativos e organizacionais necessários ao efetivo exercício das atribuições de regulação e supervisão da educação superior;

II - coordenar e promover estudos e pesquisas relacionados aos procedimentos de regulação e supervisão da educação superior;

III - identificar e propor a adoção de instrumentos, metodologias, parcerias e soluções tecnológicas capazes de ampliar e fortalecer a capacidade regulatória do MEC;

IV - viabilizar a incorporação de metodologias de análise de impacto regulatório e de supervisão baseada em risco no âmbito da atividade regulatória da educação superior;

V - promover a institucionalização, a uniformização de procedimentos e a desburocratização, de modo a tornar mais eficiente e transparente a condução dos processos de regulação e de supervisão;

VI - sistematizar e qualificar os subsídios técnicos, administrativos e jurídicos destinados ao processo de tomada de decisão;

VII - promover a cooperação com os órgãos de defesa da concorrência e defesa do consumidor;

VIII - aprimorar mecanismos e canais de participação da sociedade no processo de regulação, sobretudo por meio de consultas e audiências públicas;

IX - instituir uma agenda regulatória, a ser revista e renovada periodicamente, de forma transparente e participativa, em conjunto com a sociedade."

${ }^{438}$ Portaria ${ }^{\circ}$ 1.006/2012, artigo $5^{\circ}$. A competência do CC-PARES está estabelecida no artigo $7^{\circ}$ :

"Art. $7^{\circ}$ Compete ao CC-PARES:

I - apresentar sugestões e avaliar propostas para formulação de políticas para a regulação e supervisão da educação superior, em consonância com as metas do Plano Nacional da Educação - PNE;

II - apresentar sugestões para a elaboração dos instrumentos de avaliação de instituições e cursos de educação superior;

III - apresentar sugestões para as ações de concepção e atualização dos referenciais e das diretrizes curriculares dos cursos superiores de graduação e tecnológicos; 
instituições federais de educação superior, de instituições de educação superior privadas com fins lucrativos; e de instituições de educação superior privadas comunitárias e confessionais, escolhidos a partir de listas tríplices elaboradas pelas entidades representativas respectivas. ${ }^{439}$

\subsection{Mecanismos de controle da atividade educacional pela sociedade e pelas corporações profissionais}

Esse subcapítulo analisará a participação da sociedade ${ }^{440}$ e das corporações profissionais na busca pela melhoria na qualidade da educação superior, a fïm de demonstrar por que esses mecanismos, isoladamente, não se prestam a induzir a melhoria da qualidade de cursos e instituições, dadas as peculiaridades jurídicas, sociais e culturais desse ramo de atividade, ${ }^{441}$ mas podem se integrar a atuação regulatória estatal.

O controle por meio da sociedade pode ser observado, internamente, pela pressão exercida por parte dos alunos para o aumento da qualidade dos cursos. No entanto,

IV - apresentar sugestões de referenciais de qualidade para a educação a distância, considerando as diretrizes curriculares da educação superior e as diversas tecnologias de informação e comunicação;

$\mathrm{V}$ - apresentar sugestões de estratégias para desenvolvimento das ações de supervisão das instituições de educação superior e cursos de graduação e sequenciais, presenciais e a distância, com vistas ao cumprimento da legislação educacional e à indução de melhorias dos padrões de qualidade da educação superior, aplicando as penalidades previstas na legislação;

VI - avaliar estudos e propor o aprimoramento das normas relativas à regulação, supervisão e avaliação da educação superior; e

VII - apresentar a proposta de seu Regimento Interno ao Ministro de Estado da Educação.”.

${ }^{439}$ Portaria $^{\circ}{ }^{1.006 / 2012,}$, artigo $6^{\circ}$ :

“Art. $6^{\circ}$ O CC-PARES será vinculado diretamente ao Gabinete do Secretário da SERES e será composto por um representante, titular e suplente, de cada um dos seguintes órgãos e entidades, designados em ato específico do Ministro de Estado da Educação:

I - Diretoria de Política Regulatória da SERES, que o presidirá;

II - Diretoria de Regulação da Educação Superior da SERES;

III - Diretoria de Supervisão da Educação Superior da SERES;

IV - Instituto Nacional de Estudos e Pesquisas Educacionais Anísio Teixeira -INEP;

V - Coordenação de Aperfeiçoamento de Pessoal de Nível Superior - CAPES;

VI - Ministério da Ciência, Tecnologia e Inovação - MCTI;

VII - instituições federais de educação superior;

VIII - instituições de educação superior privadas com fins lucrativos;

IX - instituições de educação superior privadas comunitárias e confessionais.

[...]

$\S 3^{\circ}$ Os representantes de que tratam os incisos VII a IX serão escolhidos a partir de listas tríplices elaboradas pelas entidades representativas das respectivas instituições.

${ }^{440}$ Preliminarmente, esse projeto utiliza a expressão "regulação pela sociedade", e não pelo "mercado", uma vez que, dado seu caráter de direito social fundamental, não pode ser a educação considerada bem propriamente suscetível de exploração econômica pelo mercado (cf. Maria Paula Dallari Bucci, “O art. 209 da Constituição 20 anos depois", p. 783.

${ }^{441}$ Em grande medida, o objetivo do Exame Nacional de Cursos, o "Provão", era de que a divulgação de dados a respeito do desempenho dos egressos diminuísse a assimetria de informações e levasse o "mercado" a valorizar os melhores cursos. 
no Brasil, esse meio de controle mostra-se, muitas vezes, ineficiente, tendo em vista um aspecto cultural muito peculiar: muitas vezes a preocupação maior do estudante é a simples obtenção do grau superior, e não a qualidade do ensino oferecido. ${ }^{442}$ Isso se deve a muitos fatores, dentre os quais o valor intrínseco do diploma. Externamente, em relação às instituições educacionais, o controle da sociedade pode se consubstanciar por meio da exigência feita pelo mercado de trabalho por profissionais formados em instituições que oferecem cursos de qualidade. Essa forma de controle pressupõe a busca pela simetria de informações, ${ }^{443}$ ou seja, a comunidade precisa ter informações adequadas a respeito da qualidade das instituições e cursos. $O$ fornecimento dessas informações também pode ficar a cargo do mercado, por meio da divulgação de rankings, ou por meio do sistema educacional. Em grande medida, o objetivo do Exame Nacional de Cursos, o "Provão", era de que a divulgação de dados a respeito da qualidade dos cursos, com base no desempenho dos egressos, levasse as pessoas a optarem pelos cursos com melhor desempenho. No entanto, a experiência prática demonstrou a ineficiência dessa forma de controle de qualidade, em grande medida, pelo fato de que as instituições, muitas vezes, estabelecem a competição por alunos pelo critério do valor das mensalidades, sacrificando a qualidade dos cursos. ${ }^{444}$

O controle de qualidade por parte das corporações profissionais se dá por meio da regulamentação a respeito do ingresso na profissão como ocorre, por exemplo, com a advocacia, por conta do Exame de Ordem para o ingresso na Ordem dos Advogados do Brasil (OAB). Nessa área, não restam dúvidas de que esse exame tem influência direta sobre a qualidade dos cursos, uma vez que a taxa de aprovação de egressos nessa prova é periodicamente divulgada, com certo grau de destaque nos meios de comunicação. ${ }^{445}$ Contudo, a existência do exame de ingresso não é a única forma possível de atuação de entidades de classe, que podem se manifestar nos processos regulatórios, integrando-as no processo regulatório educacional estatal.

${ }^{442}$ Cf. Claudio Mendonça Braga, “Construção de novos parâmetros de avaliação qualitativa: a relação entre o Ministério da Educação e a Ordem dos Advogados do Brasil na atividade de regulação e supervisão dos cursos jurídicos", in Paulo Roberto Moglia Thompson Flores (coord.), Desafios rumo à educação jurídica de excelência, Brasília: $\mathrm{OAB}, 2011$, p. 127.

${ }^{443}$ A assimetria de informações constitui-se em uma distribuição irregular de informações no mercado, que podem inviabilizar seu funcionamento, uma vez que os diversos agentes que participam do processo econômico detêm diferentes graus de informação, indicando que alguns dispõem de melhor condição de escolha que outros (cf. Calixto Salomão Filho, Regulação da atividade econômica: princípios e fundamentos jurídicos, 2. ed., São Paulo: Malheiros, 2008, p. 199, e Marçal Justen Filho, Curso de Direito Administrativo, p. 659).

${ }_{444}$ Cf. Claudio Mendonça Braga, “Construção de novos parâmetros de avaliação qualitativa”, pp. 127-128.

${ }^{445}$ Claudio Mendonça Braga, “Construção de novos parâmetros de avaliação qualitativa”, p. 128. 
Luiz Antônio Cunha apresenta três possíveis modelos de regulação da educação superior. O primeiro seria a regulação realizada pelo mercado, conforme os padrões norte-americanos: instituições privadas (ditas independentes) assumiriam o papel do Estado na avaliação e no credenciamento de instituições, induzindo os estudantes consumidores da "mercadoria ensino" - e os empregadores - como consumidores da "mercadoria força de trabalho" a orientar a busca pela qualidade. ${ }^{446} \mathrm{O}$ segundo modelo seria a montagem de um sistema que todas as instituições fossem controladas e financiadas diretamente pelo Estado. ${ }^{447} \mathrm{O}$ terceiro modelo seria uma combinação dos dois anteriores, estabelecido nos seguintes termos:

"Da vertente estatal, a proposta aqui defendida contém a supervisão direta e reforçada do Estado sobre os meios de ensino de cada instituição, incluindo os currículos, os docentes, os laboratórios, os acervos bibliográficos etc. A avaliação institucional, à imagem da proposta pelo Sistema Nacional de Avaliação da Educação Superior (SINAES) seria o ponto de partida do aparato pelo qual o Estado - o governo federal à frente - asseguraria à sociedade que cada IES teria os meios para cumprir com os requisitos estabelecidos para o ensino superior.

\section{$[\ldots]$}

"Da vertente mercadológica, a proposta aqui defendida contém a orientação de pautar o exercício profissional de acordo com os padrões estabelecidos pelo mercado. Além de reduzir a pauta das profissões regulamentadas por lei, ao contrário de nossa vocação credencialista atávica $[\ldots]]^{, 448}$

Enquanto o primeiro modelo se relaciona com sistemas educacionais eminentemente privados e, o segundo, com sistemas públicos, o terceiro modelo mostra-se mais adequado a sistemas nos quais coexistem instituições públicas e privadas. Por essa razão, é a concepção adotada pela regulação da educação superior no Brasil, com a criação de um sistema estatal de regulação, do qual participam as entidades de classe e que, por meio da divulgação de indicadores de qualidade, busca também influenciar a escolha por instituições e cursos com melhores padrões de qualidade.

Dessa forma, os controles realizados pela sociedade e por parte das corporações profissionais não se prestam isoladamente à garantia do estabelecimento de

\footnotetext{
446 Cf. Luiz Antônio Cunha, "Desenvolvimento desigual e combinado no ensino superior - Estado e mercado", Educação \& Sociedade 25 (2004), p. 810.

447 Cf. Luiz Antônio Cunha, "Desenvolvimento desigual e combinado no ensino superior - Estado e mercado", Educação \& Sociedade 25 (2004), p. 810.

${ }^{448}$ Luiz Antônio Cunha, "Desenvolvimento desigual e combinado no ensino superior - Estado e mercado", Educação \& Sociedade 25 (2004), p. 811.
} 
padrões de qualidade na educação superior em sistemas em que coexistem instituições públicas e privadas, embora possam, de certa maneira, ser incorporados ao sistema estatal de regulação nessa área.

\subsection{Panorama da regulação da educação superior no mundo}

É importante verificar em que medida experiências de regulação da educação em outros países podem ser úteis para a construção de um sistema regulatório da educação no Brasil, desde que, evidentemente, sejam consideradas peculiaridades sociais, culturais e jurídicas de nosso país.

A Declaração Mundial sobre Educação Superior no Século XXI: Visão e Ação, elaborada em conferência promovida pela UNESCO em Paris, em 1998, ${ }^{449}$ colocou o desenvolvimento e qualidade da educação superior como desafio, compreendendo-a como conceito multidimensional, que envolve a autoavaliação e avaliação externa, realizada por especialistas independentes. Além disso, propõe a criação de instâncias nacionais independentes, reconhecidas no plano internacional, nas quais os protagonistas deveriam ser parte integrante do processo. ${ }^{450}$

Os países europeus, por meio da Declaração Conjunta dos Ministros da Educação Europeus - Declaração de Bolonha - assinada nessa cidade em de junho de

\footnotetext{
${ }^{449}$ Conferência Mundial sobre a Educação Superior no Século XXI.

${ }^{450}$ Declaração Mundial sobre Educação Superior no Século XXI: Visão e Ação, 1998, artigo 11: "Artigo 11 - Avaliação da qualidade
}

a) A qualidade em educação superior é um conceito multidimensional que deve envolver todas as suas funções e atividades: ensino e programas acadêmicos, pesquisa e fomento da ciência, provisão de pessoal, estudantes, edifícios, instalações, equipamentos, serviços de extensão à comunidade e o ambiente acadêmico em geral. Uma autoavaliação interna transparente e uma revisão externa com especialistas independentes, se possível com reconhecimento internacional, são vitais para assegurar a qualidade. Devem ser criadas instâncias nacionais independentes e definidas normas comparativas de qualidade, reconhecidas no plano internacional. Visando a levar em conta a diversidade e evitar a uniformidade, deve-se dar a devida atenção aos contextos institucionais, nacionais e regionais específicos. Os protagonistas devem ser parte integrante do processo de avaliação institucional.

b) A qualidade requer também que a educação superior seja caracterizada por sua dimensão internacional: intercâmbio de conhecimentos, criação de redes interativas, mobilidade de professores e estudantes, e projetos de pesquisa internacionais, levando-se sempre em conta os valores culturais e as situações nacionais. c) Para atingir e manter a qualidade nacional, regional ou internacional, certos componentes são particularmente relevantes, principalmente a seleção cuidadosa e o treinamento contínuo de pessoal, particularmente a promoção de programas apropriados para o aperfeiçoamento do pessoal acadêmico, incluindo a metodologia do processo de ensino e aprendizagem, e mediante a mobilidade entre países, instituições de educação superior, os estabelecimentos de educação superior e o mundo do trabalho, assim como entre estudantes de cada país e de distintos países. As novas tecnologias de informação são um importante instrumento neste processo, devido ao seu impacto na aquisição de conhecimentos teóricos e práticos.". 
1999, criou o Espaço Europeu do Ensino Superior: buscando a integração de seus sistemas educacionais superiores, a fim de aprimorar os mecanismos de mobilidade acadêmica de estudantes, para desenvolver "a empregabilidade dos cidadãos europeus e a competitividade do Sistema Europeu do Ensino Superior”. Esse sistema pressupõe uma a padronização de critérios regulatórios, incentivando a cooperação europeia para a adoção de critérios e metodologias comparáveis, a fim de garantir da qualidade dos cursos.

A adoção do Espaço Europeu de Ensino Superior tem fins políticos, pois, além de buscar a efetiva integração europeia, por meio da mobilidade estudantil, visa também a promover o sistema europeu de educação superior em todo o mundo, tornando-o competitivo em face do norte-americano, principalmente, com o intuito de atrair estudantes de outros continentes. ${ }^{451}$

O Processo de Bolonha surgiu em um contexto no qual a importância da regulação da educação superior já estava em debate. Procedimentos sistemáticos de avaliação da educação superior, visando à garantia e melhoria de sua qualidade, foram implementados na Europa Ocidental desde meados da década de 1980. As experiências recolhidas por diversos estudos mostram que, em todos os países, procedimentos de avaliação multidimensionais constituíram o principal instrumento de garantia de qualidade e foram ganhando gradualmente aceitação no meio acadêmico. ${ }^{452}$

Alfredo Pérez Boullosa aponta que, embora mecanismos de avaliação e acreditação tenham sido adotados pelos países da Europa, seus desenhos institucionais são distintos: em alguns países, esse processo é realizado por órgãos governamentais (França, Itália e Espanha), em outros, por agências independentes (Reino Unido, Holanda e Bélgica), alguns adotam regimes mistos (Dinamarca e Finlândia), e outros se utilizam de mecanismos supranacionais (Alemanha, Suíça e Áustria). ${ }^{453}$ Em geral, os países desse continente iniciaram o processo de institucionalização da avaliação de qualidade na educação superior a partir dos anos 1980, intensificando esse processo nos anos 1990.

\footnotetext{
${ }^{451}$ Licínio C. Lima / Mário Luiz Neves de Azevedo / Afrânio Mendes Catani, "O processo de Bolonha, a avaliação da educação superior e algumas considerações sobre a universidade nova", Avaliação 13 (1) (2008), p. 10

${ }^{452452}$ Cf. L. Bornmann / S. Mittag / H. D. Daniel, "Quality assurance in higher education - meta-evaluation of multi-stage evaluation procedures in Germany", Higher Education 52 (2006), p. 688.

${ }^{453}$ Cf. Alfredo Pérez Boullosa, "Garantía de calidad en la enseñanza en el espacio europeo de educación superior", Cuadernos de Integración Europea 2 (2005), p. 46.
} 
O Reino Unido foi um dos primeiros países a adotar a avaliação da superior, a partir dos anos 1980, sob influência do pensamento neoliberal do Governo Thatcher, promovendo extensas reformas no setor, a fim de estabelecer reformas em seus mecanismos de accountability e criando da Agência de Garantia da Qualidade (Quality Assurance Agency - QAA) em $1997 .{ }^{454}$ Dado o contexto político de sua criação, a ênfase está na aferição da eficiência na utilização dos recursos na busca de melhores resultados.

A França se utiliza de um método de avaliação da educação superior diferente do usado no Reino Unido, no qual o Comitê Nacional de Avaliação dos Serviços Públicos Científicos, Culturais e Profissionais (Comité National de l'Évaluation des Établissements Publics à Caractère Scientifique, Culturel et Professionnel - CNE) organiza comentários externos e avaliações baseadas em entrevistas locais e por meio da publicação de relatórios com ênfase nos aspectos acadêmicos. ${ }^{455}$

Tanto no Reino Unido como na França, a avaliação tem sido vista como um elemento estratégico para a internacionalização de sua educação superior. Cada um desses países tem suas próprias agências de avaliação, atualmente compreendidos como fiadoras da qualidade do ensino superior nacional. ${ }^{456}$

No caso da Alemanha, em meados da década de 1990, foi iniciado, por meio da iniciativa de um grupo de instituições acadêmicas, um processo de avaliação multidimensional, que incluía avaliação interna, avaliação externa e acompanhamento da implementação das recomendações. ${ }^{457}$

Ainda nos anos de 1990, a educação superior na Itália promoveu alterações em seu sistema de avaliação da educação superior, a fim de alinhá-lo com os demais sistemas europeus. As mudanças foram efetuadas por meio de leis e regulamentações administrativas, que resultaram em mudanças institucionais, como a criação do Ministério da Universidade e Pesquisa Científica. O sistema italiano de avaliação da educação superior foi estruturado tendo a avaliação interna como elemento principal, por meio de

\footnotetext{
${ }^{454}$ Cf. Jiang Kai, "A critical analysis of accountability in higher education: its relevance to evaluation of higher education”, Chinese Education and Society 42(2) (2009), pp. 45-46.

${ }^{455}$ Cf. Jiang Kai, "A critical analysis of accountability in higher education: its relevance to evaluation of higher education", Chinese Education and Society 42(2) (2009), p. 46

${ }^{456} \mathrm{Cf}$. Anneliese Dodds, "British and french evaluation of international higher education issues: an identical political reality?”, European Journal of Education 40 (2) (2005), p. 155.

${ }^{457}$ Cf. L. Bornmann / S. Mittag / H. D. Daniel, “Quality assurance in higher education”, pp. 689-692.
} 
unidades de autoavaliação nas instituições, mas também prevendo mecanismos de avaliação externa, em grau limitado, compreendendo diversos atores. ${ }^{458}$

Conforme apontado, o Processo de Bolonha se desenvolveu a partir de um ambiente em que experiências de institucionalização da avaliação da educação superior já estavam em curso nos países europeus. Para empreender o processo de integração da educação desses países, no entanto, seria necessário que os cursos e instituições pudessem ser comparáveis em relação à qualidade. Por essa razão, no curso da institucionalização desse processo, foi realizada a Conferência de Berlim, em 2003, que, em seu comunicado, prescreveu o estabelecimento de critérios e procedimentos transparentes e comparáveis para a qualidade da educação superior. Nessa linha, foi proposto o fortalecimento da Rede Europeia para Garantia da Qualidade da Educação Superior (European Network for Quality Assurance in Higher Education - ENQA), composta por mais de quarenta agências europeias de avaliação. ${ }^{459}$ Como consequência, essa rede foi institucionalizada, por meio de entidade autônoma, ${ }^{460}$ pela criação da Associação Europeia para Garantia da Qualidade da Educação Superior (European Association for Quality Assurance in Higher Education). ${ }^{461}$ Sua consolidação, no entanto, mostra-se como tarefa complexa no que diz respeito ao estabelecimento de consenso entre tantos diferentes sistemas nacionais, que têm procedimentos e critérios metodológicos diferentes. ${ }^{462} \mathrm{Na}$ mesma linha, com objetivo de desenvolver e padronizar critérios e metodologias a serem adotadas nas decisões sobre acreditação, em 2003, foi criado o Consorcio Europeu de Acreditação (ECA). ${ }^{463}$

A China, no início do século XXI, apresentou uma expansão do sistema de educação superior extremamente acentuada, superando as metas estabelecidas em seu Décimo Plano Quinquenal (2001-2005). O grau acentuado dessa expansão influenciou uma mudança de política no Décimo Primeiro Plano Quinquenal (2006-2010), alterando o foco da política de expansão e massificação da educação superior para o desenvolvimento de

\footnotetext{
${ }^{458}$ Cf. Stefano Boffo / Roberto Moscati, "Evaluation in the italian higher education system: many tribes, many territories... many godfathers", European Journal of Education 33 (3) (1998), p. 349-354.

${ }^{459}$ Cf. Ignacio Javier Alfaro Rocher, "El Espacio Universitario Europeo: entre la autonomía, la diversidad y la convergência", Cuadernos de Integración Europea 2 (2005), pp. 13-14.

${ }^{460}$ Cf. Francisco Marcellán Español, "Criterios de garantía de calidad en educación superior: praxis europea", Educatio 23 (2005), pp. 16-17.

${ }^{461}$ Cf. Alfredo Pérez Boullosa, "Garantía de calidad en la enseñanza en el espacio europeo de educación superior", Cuadernos de Integración Europea 2 (2005), p. 49.

${ }^{462}$ Ignacio Javier Alfaro Rocher, "El Espacio Universitario Europeo: entre la autonomía, la diversidad y la convergência", Cuadernos de Integración Europea 2 (2005), pp. 13-14.

${ }^{463}$ Cf. Francisco Marcellán Español, "Criterios de garantía de calidad en educación superior: praxis europea", Educatio 23 (2005), pp. 16-17.
} 
sua qualidade. No bojo dessa mudança, foi lançado o Projeto Nacional de Avaliação do Ensino e Aprendizagem da Graduação Nacional, ${ }^{464}$ uma plataforma para o debate nacional entre os estudiosos e administradores universitários a respeito de conceitos e práticas de garantia de qualidade, institucional e programática, acreditação, avaliação da qualidade e avaliação, que, até o final de 2008, avaliou 516 instituições regulares de ensino superior, com a perspectiva de ampliação desse universo. ${ }^{465}$ Esse processo vem operando significativas mudanças na política de educação superior: o processo de consolidação de um sistema de avaliação no qual fazem parte muitos atores fez diminuir a intervenção direta do Estado nas instituições educacionais. ${ }^{466}$

Nos Estados Unidos o sistema de acreditação teve inicialmente um caráter voluntário e interinstitucional, de natureza privada, sendo o principal mecanismo de controle de qualidade da educação superior durante mais de um século de que dispunham as universidades e outros centros de educação superior para alcançar prestígio. ${ }^{467}$

Os países da América Latina também operaram, nesse período, alterações em seus sistemas educacionais superiores, estabelecendo mecanismos de regulação. Cinco anos após a Conferência Mundial sobre a Educação Superior no Século XXI, o Instituto Internacional para a Educação Superior na América Latina e no Caribe, da UNESCO (Iesalc) elaborou um relatório, no qual apontou que, entre 1998 e 2003, os países da região operaram significativas mudanças em seus sistemas de educação superior, entre as quais, o desenvolvimento de sistemas nacionais de avaliação e acreditação da educação superior. ${ }^{468}$

\footnotetext{
464 "National Undergraduate Teaching and Learning Evaluation Project", tradução do chinês "Quanguo benke jiaoxue gongzuo shuiping pinggu".

${ }^{465}$ Cf. Yuhao Cen / Heidi Ross, "Chinese higher education and evaluation in context", Chinese Education and Society 42(2009), pp. 3-4.

466 Cf. Jiang Kai, "A critical analysis of accountability in higher education: its relevance to evaluation of higher education”, Chinese Education and Society 42(2) (2009), p. 46.

${ }^{467}$ Cf. Inmaculada Egido Gálvez / Guy Haug, "La acreditación como mecanismo de garantía de la calidad: tendencias en el espacio europeo de educación superior", Revista Española de Educación Comparada, 12 (2006), p. 94. Nesse sentido, vide . Jiang Kai, "A critical analysis of accountability in higher education: its relevance to evaluation of higher education", Chinese Education and Society 42(2) (2009), p. 46.

${ }^{468}$ Cf. UNESCO, Reforms and Innovation in Higher Education in Some Latin American and Caribbean Countries, 1998-2003. Caracas: UNESCO-IESALC, 2003, pp. 1-2. Outras mudanças apontadas no relatório são: (a) o aumento no número das instituições de educação superior e diversificação das suas modalidades; (b) o aumento e diversificação das associações e redes de universidades, como instrumento de cooperação; (c) o desenvolvimento de novos modelos de ensino superior; (d) o crescente interesse em usar as novas tecnologias de informação e comunicação para o desenvolvimento das atividades educacionais; (e) a internacionalização do ensino superior; e (f) o crescente interesse no desenvolvimento de projetos de cooperação entre instituições de ensino superior e empresas e outras organizações (cf. Cf. UNESCO, Reforms and Innovation in Higher Education in Some Latin American and Caribbean Countries, pp. 1-2.
} 
No entanto, em grande medida, essa pauta foi colocada nos países da região, nos anos 1990, em um contexto de implementação de políticas de ajuste fiscal nas economias latino-americanas Por essa razão, o discurso da qualidade da educação superior se deu pela adoção de políticas públicas com ênfase do desempenho (eficiência), por meio menor custo e controle quantitativo do desempenho das instituições. ${ }^{469}$

\section{A Declaração da Conferência Regional de Educação Superior na América} Latina e no Caribe, de 2008, preparatória da Conferência Mundial sobre o Ensino Superior, realizada pela UNESCO, em 2009, estabeleceu a consolidação e integração dos sistemas de avaliação da educação superior como desafio para os países da região:

"O fortalecimento do processo de convergência dos sistemas de avaliação e revalidação nacionais e sub-regionais, visando dispor de padrões e procedimentos regionais de garantia de qualidade da Educação Superior e da pesquisa para projetar sua função social e pública. Os processos de revalidação regionais devem estar legitimados pela participação das comunidades acadêmicas, contar com a contribuição de todos os setores sociais e abordar a qualidade como um conceito inseparável da equidade e da pertinência." ${ }^{470}$

Vê-se, diante do exposto, que, em geral, o debate e a consolidação de sistemas de regulação da educação superior estão fortemente presentes, no plano internacional, desde a década de 1990. O Brasil não ficou alheio à essa discussão, que influenciou diretamente a criação do Sistema Nacional de Avaliação da Educação Superior - SINAES, em 2004.

${ }^{469}$ Vladmir Oliveira da Silveira / Irene Patrícia Nohara, "Supervisão do ensino superior de direito no contexto federativo e complexidades do controle da pós-graduação stricto sensu", pp. 279-280.

${ }^{470}$ Declaração da Conferência Regional de Educação Superior na América Latina e no Caribe. Avaliação 14 (2009), p. 245. 


\section{Capítulo 4 MARCO REGULATÓRIO DA EDUCAÇÃO SUPERIOR}

\subsection{Marco regulatório da educação superior: delimitação}

Apenas o controle da sociedade e o das corporações profissionais não são suficientes para que a educação superior alcance os níveis desejados de qualidade. ${ }^{471} \mathrm{Nessa}$ área, cabe ao Estado um papel mais amplo do que o da organização das informações oriundas de exames nacionais de curso - como o "Provão" - para fins de regulação pela sociedade, baseada na livre orientação dos estudantes em relação aos cursos disponíveis, de acordo com seu desempenho: ${ }^{472}$

“O Estado passa a atuar como regulador e supervisor efetivo, utilizando os referenciais da avaliação para exigir comportamentos das instituições de ensino, os quais, se não cumpridos adequadamente, podem levar à exclusão da instituição ou curso do "mercado". A atuação estatal, assim, termina por conformar os limites do mercado, devendo resultar na qualificação dos serviços oferecidos, visto que o universo da oferta passará a ser limitado pelo atendimento a um padrão tido como satisfatório de qualidade." ${ }^{, 43}$

Vladmir Oliveira da Silveira e Irene Patrícia Nohara apontam que a previsão de um marco regulatório constitucional de controle da atividade educacional é fundamentada no fato de que o objetivo constitucional de generalização da educação ultrapassa o mero desenvolvimento da pessoa humana considerada individualmente, mas mostra-se fundamental ao desenvolvimento nacional sustentável. ${ }^{474}$ Por essa razão é importante a criação de um modelo de avaliação institucionalizado.

Nos termos da determinação constitucional a atividade educacional é permitida à iniciativa privada, condicionada a obtenção de ato autorizativo por parte do Poder Público, condicionado à avaliação periódica de qualidade pelo Poder Público. O dispositivo constitucional relativo à avaliação de qualidade, contido no artigo 209, foi disciplinado, de forma genérica, pela Lei de Diretrizes e Bases da Educação de 1996, que,

\footnotetext{
${ }^{471}$ Cf. 3.4.

472 Cf. Maria Paula Dallari, “O art. 209 da Constituição 20 anos depois”, p. 783.

${ }^{473}$ Maria Paula Dallari, "O art. 209 da Constituição 20 anos depois”, p. 783.

${ }^{474}$ Cf. Vladmir Oliveira da Silveira / Irene Patrícia Nohara, "Supervisão do ensino superior de direito no contexto federativo e complexidades do controle da pós-graduação stricto sensu”, pp. 278-279.
} 
em primeiro lugar, estabeleceu a competência da União a esse respeito no que diz respeito a seu sistema de ensino:

“Art. 9 A União incumbir-se-á de:

\section{$[\ldots]$}

VIII - assegurar processo nacional de avaliação das instituições de educação superior, com a cooperação dos sistemas que tiverem responsabilidade sobre este nível de ensino;

IX - autorizar, reconhecer, credenciar, supervisionar e avaliar, respectivamente, os cursos das instituições de educação superior e os estabelecimentos do seu sistema de ensino."

Dessa maneira, a competência da União nessa matéria é ampla, mas exclui a regulação da educação superior desenvolvida por instituições públicas estaduais e municipais. $^{475}$

Em segundo lugar, a LDB definiu os atos regulatórios e o poder-dever do Estado em buscar o saneamento de deficiências de qualidade de cursos superiores, apontados em processos de avaliação:

"Art. 46. A autorização e o reconhecimento de cursos, bem como o credenciamento de instituições de educação superior, terão prazos limitados, sendo renovados, periodicamente, após processo regular de avaliação.

$\S 1^{\circ}$ Após um prazo para saneamento de deficiências eventualmente identificadas pela avaliação a que se refere este artigo, haverá reavaliação, que poderá resultar, conforme o caso, em desativação de cursos e habilitações, em intervenção na instituição, em suspensão temporária de prerrogativas da autonomia, ou em descredenciamento."

Dessa forma, a Lei de Diretrizes e Bases da Educação definiu quais são os atos autorizativos em matéria de educação superior (autorização, reconhecimento e renovação de reconhecimento de cursos; credenciamento e recredenciamento de instituições), previu a necessidade de sua renovação periódica e definiu que o Estado tem o poder-dever de buscar o saneamento de deficiências na prestação da atividade educacional superior, que, se não atingido, poderá ensejar as penalidades mencionadas. A legislação, assim, traz os contornos básicos da atividade de avaliação, regulação e supervisão da educação superior, sem, no entanto, trazer disposições que venham a instrumentalizar tal atividade.

No entanto, no plano infralegal havia um ambiente de provisoriedade normativa, consubstanciada em uma política decisória caracterizada pela edição quase 
diária de novas normas, em geral portarias ministeriais, cada uma cuidando de aspectos particulares de determinadas situações, muitas vezes contraditórias entre si. Criou-se um ambiente de dificuldade para se saber a norma aplicável a um caso, propiciando ampla margem de discricionariedade administrativa - e o consequente campo para contestação judicial, quando algum interesse particular se via contrariado pela ação do Poder Público. ${ }^{476}$

Por essa razão, para a efetivação dos mencionados preceitos constitucionais e legais relativos à avaliação de qualidade da educação superior, fazia-se necessário, ainda, o estabelecimento de um conjunto de conceitos fundamentais para o desenvolvimento da atividade regulatória, por meio de um arcabouço jurídico - legal e infralegal - que estabelecesse a organização institucional e os instrumentos e critérios procedimentais para que tal finalidade fosse atingida. Esse conjunto de normas jurídicas produzidas a partir de 2004 é o que aqui se denomina o novo marco regulatório da educação superior.

Esse marco regulatório é baseado nas seguintes premissas: a consolidação da atividade administrativa por meio da estruturação de um procedimento administrativo, a fim de possibilitar um maior grau de racionalidade administrativa, de garantia de direitos e de acesso à informação. Segundo Maria Paula Dallari Bucci, a reforma do marco regulatório da educação superior compreendeu um triplo movimento: uma reformulação normativa, a adoção de mecanismos de tecnologia da informação e de comunicação - com a criação do processo exclusivamente eletrônico, no sistema e-MEC -, e uma profunda revisão organizacional, centrada na mudança dos fluxos e processos de trabalho. ${ }^{477}$

A fim de conferir efetividade aos comandos normativos mencionados e a atingir as metas estabelecidas no Plano Nacional de Educação, foi promulgada a Lei $\mathbf{n}^{\mathbf{o}}$ 10.861, de 14 de abril de 2004, que criou o Sistema Nacional de Avaliação da Educação Superior - SINAES, ${ }^{478}$ estabelecendo o marco legal para as atividades de avaliação, regulação e supervisão da educação superior. ${ }^{479}$

${ }^{476}$ Cf. Maria Paula Dallari Bucci, "Processo administrativo eletrônico e informação pública: o sistema eMEC e o marco regulatório da educação superior", 2013, no prelo.

${ }^{477}$ Cf. Maria Paula Dallari Bucci, "Processo administrativo eletrônico e informação pública".

${ }^{478}$ Cf. 4.3 .

479 As três atividades mencionadas - avaliação, regulação e supervisão - se inserem no conceito de regulação, compreendida como atividade regulatória do Estado. Por essa razão, a fim de dirimir a ambiguidade do termo regulação, esse trabalho utilizará essa expressão no seu sentido amplo, de atividade regulatória estatal, utilizando a expressão regulação em sentido estrito para designar especificamente a expedição dos atos regulatórios de autorização, reconhecimento, renovação de reconhecimento, 
Posteriormente, no plano infralegal, foi expedido o Decreto $\mathrm{n}^{\circ} 5.773$, de 9 de maio de 2006, que estabeleceu normas relativas à avaliação, regulação (em sentido estrito) e supervisão da educação superior, disciplinando a necessária relação entre essas três dimensões da atividade estatal: os resultados obtidos na avaliação passaram a ter efeitos práticos para fins de regulação (em sentido estrito) e supervisão. Pelo fato de interrelacionar essas três dimensões, essa norma também é conhecida como decreto-ponte.

Outra importante normatização trazida no bojo da institucionalização do novo marco regulatório foi a Portaria Normativa MEC $n^{\circ}$ 40, de 12 de dezembro de 2007, que instituiu o e-MEC, sistema eletrônico de fluxo de trabalho e gerenciamento de informações relativas aos processos de regulação da educação superior no sistema federal de educação. Esse sistema, além de criar uma nova dinâmica e cultura processual, com menor grau de formalismo e focada nos aspectos materiais da oferta educacional. Em momento posterior, a Portaria Normativa $n^{\circ} 40 / 2007$ foi alterada pela Portaria Normativa $n^{\circ} 23$, de 29 de dezembro de 2010, que trouxe inovações, incorporou disposições contidas em outras normas e revogou uma grande quantidade de normas, promovendo a racionalização do sistema regulatório da educação superior.

O estabelecimento da necessária relação entre avaliação, regulação (em sentido estrito) e supervisão da educação superior geraram críticas no meio acadêmico, por conta de uma visão de que a avaliação deve servir como estímulo à melhoria da qualidade no âmbito interno das instituições, e não por meio de imposições estatais:

"A avaliação, um dos princípios da identidade universitária, põe-se no trabalho acadêmico como síntese, no plano ético, do que até agora se discutiu sobre a educação superior como mercadoria. A proposta do SINAES, produzida pela Comissão Especial de Avaliação da Educação Superior, orientava-se pela ética que se origina na cultura universitária moderna. No entanto, quando da transformação da proposta em lei, foi repolitizada segundo os objetivos de controle e regulação da educação superior, colocando, em princípio, em risco o próprio estatuto da autonomia, conseqüientemente, da democratização universitária e de sua gestão." ${ }^{480}$

No entanto, os objetivos de regulação não foram politizados no estabelecimento do marco regulatório da educação superior, o que se buscou foi extrair efeitos públicos das avaliações insatisfatórias, tal como previstas no artigo 10 da Lei do

credenciamento, e recredenciamento. Dessa maneira, para esse trabalho, regulação abrange as atividades de avaliação, regulação em sentido estrito e supervisão.

480 João dos Reis Silva Júnior / Valdemar Sguissardi, “A nova lei de educação superior: fortalecimento do setor público e regulação do privado/mercantil ou continuidade da privatização e mercantilização do público?”, Revista Brasileira de Educação 29 (2005), pp. 24-25. 
SINAES e, no mesmo sentido, do art. 46 da LDB, em observância a princípios e objetivos estabelecidos na Constituição.

\subsection{Expansão da educação superior no Brasil}

Para uma adequada compreensão do contexto em que o marco regulatório da educação superior foi implantado, é necessário que se tenha em mente o quadro de expansão da oferta de educação superior no Brasil nas últimas décadas.

O aumento da participação privada na educação superior foi acelerado nos oito anos de governo de Fernando Henrique Cardoso. Nesse período, o número de instituições privadas aumentou consideravelmente, em especial nas categorias universidade e centro universitário, o que resultou na ampliação do percentual de alunos abrangido por esse setor. ${ }^{481}$ Nesse período, foi instituído por meio da Lei $\mathrm{n}^{\mathrm{o}} 9.131$, de 24 de novembro de 1995, o Exame Nacional de Cursos (ENC), que ficou conhecido como "Provão", aplicado anualmente com base nos conteúdos mínimos estabelecidos para cada curso, destinado a aferir os conhecimentos e competências adquiridos pelos alunos em fase de conclusão dos cursos de graduação. Dessa maneira, o foco do Provão era o curso, e não na instituição, com ênfase nos resultados obtidos. ${ }^{482}$ Em grande medida, a instituição do Provão tinha por pressuposto a regulação da educação superior por meio da diminuição da assimetria de informações no setor, com a crença de que a divulgação anual de resultados levaria as pessoas a optarem por cursos mais bem avaliados, forçando os cursos com piores desempenhos a melhorar para não perder alunos. No entanto, esse modelo de regulação do mercado do ensino superior não vingou, ${ }^{483}$ por se mostrar insuficiente, exigindo o estabelecimento de um sistema regulatório estatal mais forte. A esse respeito, Luiz Antônio Cunha afirma:

"O sentido das normas foi o de estabelecer um capitalismo concorrencial, no qual o investimento realizado em instituições de ensino deixasse de usufruir de condições

${ }^{481}$ Cf. Luiz Antônio Cunha, "Desenvolvimento desigual e combinado no ensino superior - Estado e mercado", p. 807.

${ }^{482}$ Cf. SINAES - Sistema Nacional de Avaliação da Educação Superior, p. 24

${ }^{483}$ Cf. Luiz Antônio Cunha, "Desenvolvimento desigual e combinado no ensino superior - Estado e mercado", p. 809. 
acintosamente privilegiadas quando comparadas com as de qualquer outro setor econômico.

Vale dizer, procurou-se estabelecer a equalização das condições da concorrência." ${ }^{484}$

Nesse sentido, houve a admissão da oferta educacional com finalidade lucrativa, em 1997, por meio da Medida Provisória n $1.477-39$, de 8 de agosto de 1997, que acrescentou dispositivos à Lei $n^{\circ} 9.131 / 1995 .{ }^{485} \mathrm{~A}$ abertura da atividade educacional ao regime lucrativo não foi acompanhado da estrutura e regramentos necessários para a realização da regulação prevista na Constituição: ${ }^{486}$

\begin{abstract}
"O resultado, em menos de uma década, foi a expansão geral e sem critério de qualidade da educação superior. Isso alimentou uma posição no senso comum contrária à ampliação da oferta, entendendo-a como sinônimo de mercantilização desqualificada. Havia, no início dos anos 2000, um clamor público pedindo medidas pelo controle de qualidade, simultâneas ao refreamento da abertura de novos cursos e instituições. ${ }^{\text {} 487}$
\end{abstract}

De qualquer maneira, o mero estabelecimento abstrato de exigências relativas à qualidade, pela LDB de 1996, já apresentou efeitos positivos. Solange Alfinito, analisando o significativo aumento da titulação de docentes como mestres e doutores, no período de 1994 a 2003, aponta que os movimentos foram mais intensos entre os anos de 1998 e 2003, indicando um claro impacto das exigências previstas na LDB de $1996 .{ }^{488}$

Apesar da ampliação expressiva do acesso à educação superior nas duas últimas décadas, o país ainda se encontra muito aquém da meta quantitativa estabelecida pelo PNE, assim como não foram plenamente atingidas as metas de diminuição da desigualdade regional da oferta. É certo que a ampliação desejada deve se concretizar, em parte significativa, por vagas na rede pública, mas também pela oferta por meio do setor privado. Nesse sentido, cabe ao Estado, principalmente: (a) ampliar a oferta de educação superior pela rede pública; (b) regular a expansão da oferta, zelando pela qualidade dos

\footnotetext{
${ }^{484}$ Luiz Antônio Cunha, "Desenvolvimento desigual e combinado no ensino superior - Estado e mercado", p. 808.

${ }^{485}$ A Lei ${ }^{\circ}$ 9.131, de 1995, passou a contar com a seguinte redação, atualmente alterada:

"Art. $8^{\circ}$ As pessoas jurídicas de direito privado, mantenedoras de instituições de ensino superior, previstas no inciso II do art. 19 da Lei no 9.394, de 20 de dezembro de 1996, poderão assumir qualquer das formas admitidas em direito, de natureza civil ou comercial e, quando constituídas como fundações, serão regidas pelo disposto no art. 24 do Código Civil Brasileiro.

[...]

Art. 11 As entidades mantenedoras de instituições de ensino superior, com finalidade lucrativa, ainda que de natureza civil, deverão: [...]”. Disponível em http://www.planalto.gov.br/ccivil_03/mpv/Antigas/147739.htm, acesso em 15.12.2012.

${ }^{486}$ Cf. Maria Paula Dallari Bucci, "Processo administrativo eletrônico e informação pública".

${ }^{487}$ Maria Paula Dallari Bucci, "Processo administrativo eletrônico e informação pública".

${ }^{488}$ Cf. Solange Alfinito, Educação superior no Brasil: análise do histórico recente (1994-2003), p. 19.
} 
cursos e instituições públicas e privadas; e (c) implementar políticas públicas de democratização do acesso à educação superior, por meio da criação de mecanismos de ingresso e permanência de estudantes de baixa renda.

\subsection{Sistema Nacional de Avaliação da Educação Superior (SINAES)}

Conforme apresentado, à luz da Constituição e da LDB, a fim de buscar a instrumentalização apta a dar plena efetivação dos dispositivos mencionados, ${ }^{489}$ foi, inicialmente, instituído no plano legal, o Sistema Nacional de Avaliação da Educação Superior - SINAES, por meio da Lei $n^{\circ} 10.861 / 2004$, que buscou assegurar um sistema integrado de avaliação que incluísse dimensões externas e internas, particulares e globais, observando critérios quantitativos e qualitativos. ${ }^{490}$ Com a Lei do SINAES, foi implementada uma nova metodologia da avaliação sistemática de instituições e cursos superiores, provendo indicadores objetivos sobre os resultados do ensino ministrado.

O SINAES tem por finalidades a melhoria da qualidade da educação superior, a orientação da expansão da sua oferta, o aumento permanente da sua eficácia institucional e efetividade acadêmica e social e, especialmente, a promoção do aprofundamento dos compromissos e responsabilidades sociais das instituições de educação superior, por meio da valorização de sua missão pública, da promoção dos valores democráticos, do respeito à diferença e à diversidade, da afirmação da autonomia e da identidade institucional. ${ }^{491}$ Foi instituída, no âmbito do Ministério da Educação, a Comissão Nacional de Avaliação da Educação Superior (CONAES), órgão colegiado de coordenação e supervisão do SINAES, com importantes atribuições no estabelecimento de parâmetros à atividade regulatória do setor, podendo ser destacadas: (a) propor e avaliar as dinâmicas, procedimentos e mecanismos da avaliação institucional, de cursos e de desempenho dos estudantes; (b) estabelecer diretrizes para organização e designação de comissões de avaliação, analisar relatórios, elaborar pareceres e encaminhar recomendações às instâncias competentes; (c) formular propostas para o desenvolvimento das instituições de educação superior, com base nas análises e recomendações produzidas nos processos de avaliação; (d) articular-se

\footnotetext{
${ }^{489}$ A inefetividade do artigo 209 da Constituição pode ser verificada pelo fato de que uma parcela expressiva das cerca de $75 \%$ das matrículas em instituições privadas, e de algumas instituições públicas, encontrarem-se em cursos com baixos indicadores de qualidade, aferidos por diversas fontes (Cf. Maria Paula Dallari Bucci, "O art. 209 da Constituição 20 anos depois", p. 781).

${ }^{490}$ Cf. SINAES - Sistema Nacional de Avaliação da Educação Superior, p. 88.

${ }^{491}$ Lei do SINAES, artigo $1^{\circ}, \S 1^{\circ}$.
} 
com os sistemas estaduais de ensino, visando a estabelecer ações e critérios comuns de avaliação e supervisão da educação superior; (e) submeter anualmente à aprovação do Ministro de Estado da Educação a relação dos cursos a cujos estudantes será aplicado o Exame Nacional de Desempenho dos Estudantes - ENADE. ${ }^{492}$ A Composição da CONAES compreende representantes do Estado e da sociedade civil, ${ }^{493}$ a fim de envolver no processo os atores envolvidos na atividade educacional superior, buscando a implementação de mecanismos de regulação reflexiva.

A promulgação da Lei do SINAES conferiu à avaliação da educação superior caráter sistêmico, conjugando situações, instrumentos avaliativos distintos e informações, em apenas uma análise globalizada, de forma inédita no direito positivo brasileiro. Essa legislação institucionalizou a avaliação a cargo do INEP, segundo diretrizes estabelecidas pela CONAES, a fim de conferir integração das políticas públicas, do processo avaliativo e dos resultados conseguidos nos procedimentos regulatórios, que visam à melhoria da qualidade da educação superior. ${ }^{494}$

O SINAES foi fruto da discussão ocorrida no país a respeito da necessidade de institucionalização de um sistema de avaliação da educação superior, que vem acontecendo em outros países há algumas décadas, refletindo também debates ocorridos em instâncias internacionais. Esse sistema nacional de avaliação, no entanto, compreende de forma vinculada apenas o sistema federal de ensino, sendo facultativa a participação de instituições de educação superior compreendidas nos sistemas estaduais. No entanto, por se tratar de um sistema nacional, há autores que sustentam a conveniência da submissão de todas as instituições de educação superior a ele. Nesse sentido, Magno Federici Gomes entende que "seria conveniente, em função de questões orçamentárias e de manutenção do padrão de qualidade, em tais instituições, que todas estivessem submetidas ao Sinaes, evitando a descentralização e a confusão nesta questão basilar."495

\footnotetext{
${ }^{492}$ Lei do SINAES, artigo $6^{\circ}$.

${ }^{493}$ Lei do SINAES, artigo $7^{\circ}$.

${ }^{494}$ Cf. Magno Federeci Gomes, "Delimitação de atribuições educacionais: sistemas de ensino e competência constitucional”, Revista Brasileira de Estudos Pedagógicos 230 (2011), pp. 182-183.

${ }^{495}$ Cf. Magno Federeci Gomes. "Delimitação de atribuições educacionais”, pp. 182-183.
} 


\subsection{Aparelhamento do Estado brasileiro para a atividade regulatória da educação superior}

Nos termos da Constituição, na Lei de Diretrizes e Bases da Educação e na Lei do SINAES cabe à União, por meio do Ministério da Educação e outras entidades, realizar a avaliação, a regulação e a supervisão dos cursos superiores do sistema federal. Para desempenhar essa importante tarefa, houve a necessidade da recomposição da autoridade do Estado, diante de um setor desregulado de fato, por meio de uma nova racionalidade administrativa e de uma atividade normativa - o novo marco regulatório da educação superior, que, fundamentado nas leis mencionadas, estabelecesse concretamente os fundamentos desse nível de ensino. Nesse sentido, um desafio colocado foi o de reconstruir a capacidade de atuação racional e transparente do Estado como uma das prioridades de uma agenda de desenvolvimento nacional, a fim de inverter a tendência de seu esfacelamento em curso desde as décadas finais do século XX, em especial dos anos 1990, em praticamente todos os âmbitos. ${ }^{496}$

Nesse sentido, ao longo da implementação do marco regulatório da educação superior foram delimitadas as competências de cada órgão e entidade participante do SINAES, a fim de conferir segurança jurídica e autoridade à atividade regulatória da educação superior, tendo em vista que a reconstrução da capacidade de atuação racional e transparente do Estado constitui uma das prioridades de uma agenda de desenvolvimento nacional.

\subsection{Regulamentação infralegal da atividade regulatória da educação superior}

Conforme visto, no plano constitucional e legal, foram estabelecidos os fundamentos da regulação da educação superior, com um considerável nível de generalidade e por meio da adoção de conceitos jurídicos indeterminados. Coube, dessa forma, ao Poder Público, a regulamentação infralegal dos mencionados dispositivos, a fim de conferir aplicabilidade efetiva a eles. Por essa razão, passa-se à análise de tais dispositivos, que se mostraram fundamentais para a consolidação do marco regulatório da educação superior.

${ }^{496}$ Cf. Maria Paula Dallari Bucci, "Processo administrativo eletrônico e informação pública". 


\subsubsection{Decreto $\mathrm{n}^{0} \mathbf{5 . 7 7 3}$, de 9 de maio de 2006}

O marco regulatório da educação superior no Brasil tem como seu instrumento normativo infralegal fundamental o Decreto $n^{\circ} 5.773 / 2006$, que regulamentou a legislação existente, que, de forma relativamente genérica, compreende a regulação da educação superior fundamentada na ideia de um procedimento administrativo destinado à produção de um ato regulatório autorizativo (credenciamento e recredenciamento de instituições, autorização, reconhecimento e renovação de reconhecimento de cursos), com base na avaliação de qualidade. Dessa maneira, esse decreto busca disciplinar o procedimento administrativo que visa à expedição de um ato autorizativo como elemento fundamental da regulação desse setor, bem como de sua renovação periódica, a fim de permitir a avaliação do desenvolvimento da atividade educacional. Dessa forma, buscou-se integrar os resultados de avaliação obtidos no SINAES à expedição de atos autorizativos de regulação, a fim de assegurar a expansão qualitativa de matrículas na educação superior, fortalecendo um sistema de avaliação unificado, consolidado e compatível com a realidade brasileira. ${ }^{497}$

O mesmo decreto também disciplina a previsão contida na LDB, para o caso de deficiências identificadas pela avaliação, da instituição poder contar com um prazo para saneamento de deficiências, após o qual haverá reavaliação, que poderá resultar, conforme o caso, em sanções administrativas (desativação de cursos e habilitações, intervenção na instituição, suspensão temporária de prerrogativas da autonomia, e descredenciamento). ${ }^{498}$

Na mesma linha, o Decreto $n^{\circ} 5.773 / 2006$ também disciplina a previsão contida na Lei do SINAES, de que os resultados de avaliação considerados insatisfatórios acarretam a celebração de protocolo de compromisso, de caráter público e disponível a todos os interessados, a ser firmado entre a instituição de educação superior e o Ministério da Educação. ${ }^{499}$

As disposições contidas no Decreto $n^{\circ} 5.773$ serão apresentadas com maior detalhamento no capítulo relativo ao procedimento regulatório da educação superior. ${ }^{500}$

\footnotetext{
${ }^{497}$ Magno Federeci Gomes. "Delimitação de atribuições educacionais”, pp. 182-183.

${ }^{498}$ Decreto no $^{\circ} 5.773 / 2006$, artigos 47 a 52.

${ }^{499}$ Decreto no $^{\circ} 5.773 / 2006$, artigos 60 a 64.

${ }^{500}$ Cf. Capítulo 5.
} 


\subsubsection{Portaria Normativa/MEC $n^{\circ} 40$, de 12 de dezembro de 2007}

A Portaria Normativa MEC n 40/2007, alterada pela Portaria Normativa MEC $\mathrm{n}^{\mathrm{o}} 23 / 2010,{ }^{501}$ instituiu o Sistema e-MEC - sistema eletrônico de fluxo de trabalho e gerenciamento de informações relativas aos processos de regulação da educação superior no sistema federal de educação, completando o marco regulatório da regulação da educação superior, realizando a consolidação de normas administrativas esparsas, realizando a revogação de uma significativa quantidade de normas, bem como trazendo disposições novas. O sistema e-MEC tem o intuito de se compatibilizar com os princípios do processo administrativo no âmbito federal, em especial na observância dos princípios da finalidade, motivação, razoabilidade, moralidade, interesse público, economia e celeridade processual e eficiência, aplicando-se, por analogia, as disposições pertinentes da Lei $\mathrm{n}^{\mathrm{o}}$ 11.419, de 19 de dezembro de 2006, que dispõe sobre a informatização do processo judicial e, subsidiariamente, as disposições da Lei $n^{\circ}$ 9.784, de 29 de janeiro de 1999, que regula o processo administrativo no âmbito da Administração Pública Federal, bem como, em grande medida, já trazendo normas compatíveis com o espírito da Lei $\mathrm{n}^{\circ} 12.527$ de 18 de novembro de 2011, que regula o acesso à informações públicas.

Essa portaria regulamentou o gerenciamento de informações relativas aos processos de regulação, avaliação e supervisão da educação superior no sistema federal de educação por meio da criação do Cadastro e-MEC, que se constitui de banco de dados de consulta pública da situação jurídica de instituições e cursos, favorecendo o controle social dessa atividade, colaborando para a diminuição da assimetria de informações no setor. O intuito do Cadastro e-MEC é o de permitir informação ao público sobre o andamento dos processos, bem como a relação de instituições credenciadas e de cursos autorizados e reconhecidos, além dos dados sobre os atos autorizativos e os elementos relevantes da instrução processual, alem de indicadores de qualidade. Os dados que integram o Cadastro e-MEC são públicos, com as ressalvas previstas na legislação. Dessa maneira, além de atender ao princípio da publicidade, propiciando o controle social da atividade regulatória do Poder Público federal e a permitir a difusão de informações ao público em geral

\footnotetext{
${ }^{501}$ O presente trabalho tratará da Portaria $n^{\circ} 40 / 2007$ com as significativas alterações trazidas pela Portaria Normativa ${ }^{\circ}$ 23/2010. Por essa razão, ao mencionar a "Portaria no 40/2007", o presente texto estará se referindo ao texto consolidado pela Portaria Normativa $n^{\circ} 23 / 2010$.
} 
No capítulo relativo ao procedimento regulatório da educação superior, serão estudadas com maior grau de detalhamento as disposições contidas na Portaria Normativa $n^{\text {o }} 40 / 2007 .^{502}$

\subsection{Posicionamento do Judiciário a respeito do novo marco regulatório}

Para a análise completa do marco regulatório da educação superior no Brasil, faz-se necessária a verificação de seu tratamento por parte do Poder Judiciário, a fim de constatar se o conjunto das atividades regulatórias implementadas está se mostrando efetivo, mesmo quando levada à apreciação judicial.

Em primeiro e segundo graus de jurisdição, já se encontra certo número de demandas nas quais, em geral, o Poder Judiciário vem considerando válidas as normas instituídas pelo novo marco regulatório da educação superior. Podem ser listadas algumas delas: mandado de segurança $n^{\circ}$ 35497-80.2009.4.01.3400/DF - 17 $7^{a}$ Vara Federal da Seção Judiciária do DF; ${ }^{.03}$ ação ordinária $n^{\circ} 85210220104013400$ /DF - 6 ${ }^{\mathrm{a}}$ Vara Federal da Seção Judiciária do DF; ${ }^{.04}$ ação ordinária $n^{\circ}$ 22889-16.2010.4.01.3400/DF - $1^{\text {a }}$ Vara Federal da Seção Judiciária do DF; ${ }^{505}$ ação cautelar no $2010.51 .01 .013360-7 / R J-30^{\text {a }}$ Vara Federal da Seção Judiciária do Rio de Janeiro; ${ }^{506}$ ação cautelar $\mathrm{n}^{\circ}$ 3892973.2010.4.01.3400/DF - 20 ${ }^{\mathrm{a}}$ Vara Federal da Seção Judiciária do Distrito Federal; ${ }^{507}$ mandado de segurança $n^{\circ}$ 35497-80.2009.4.01.3400/DF - 22 ${ }^{\mathrm{a}}$ Vara Federal da Seção Judiciária do DF. ${ }^{508}$

Em razão de se tratar de tratamento jurídico recente para a matéria, de maneira geral, o marco regulatório da educação superior recebeu pouco tratamento de mérito pelos tribunais superiores. Merece destaque a decisão proferida na Ação Direta de Inconstitucionalidade $\mathrm{n}^{\circ} 2501$, que confirmou a submissão de instituições que, embora

\footnotetext{
502 Cf. Capítulo 5.

${ }^{503}$ Instituição de ensino objetiva o desarquivamento do pedido administrativo de autorização do curso.

${ }^{504}$ Instituição de ensino objetiva a não divulgação de seu Índice Geral de Cursos - IGC, bem como o desarquivamento do pedido de autorização de curso.

${ }^{505}$ Instituição de ensino objetiva a modificação de seu Índice Geral de Cursos - IGC.

${ }^{506}$ Instituição de ensino objetiva a suspensão das penalidades aplicadas pelo MEC, que resultaram no descredenciamento de curso.

${ }^{507}$ Instituição de ensino objetiva a suspensão das penalidades aplicadas pelo MEC que resultaram no seu descredenciamento para prestar serviço educacional à distância.

${ }^{508}$ Instituição de ensino objetiva a anulação de medida tomada pelo MEC que resultou na redução do número de vagas ofertadas em curso.
} 
criadas pelos estados e municípios, fossem mantidas pela iniciativa privada, ao Sistema Nacional de Avaliação da Educação Superior - SINAES. ${ }^{509}$

Em outra decisão significativa, o Supremo Tribunal Federal, no acórdão do julgamento do Recurso Ordinário em Mandado de Segurança no 27.666, relatado pelo Ministro Dias Toffoli, entendeu ser válida a disciplina do marco regulatório da educação superior por meio de normas infralegais, uma vez que decorre de poder regulamentar adequadamente utilizado para a regulamentação de dispositivos estabelecidos em lei:

“A Constituição Federal estabelece que o acesso à educação é "direito de todos e dever do Estado e da família" (art. 205). A prestação desse serviço público essencial pelo Estado será prestado, em regime de colaboração, pela União, pelos Estados, pelo Distrito Federal e pelos Municípios (art. 211, CF/88).

Embora seja dada primazia ao ensino público no texto constitucional, também a iniciativa privada poderá oferecer o ensino em todos os seus níveis e modalidades, estando condicionada a sua atuação ao "cumprimento das normas gerais da educação nacional" e à "autorização e avaliação de qualidade pelo Poder Público", conforme disposto no art. 209 da Constituição Federal.

Promulgou-se a Lei federal no 9.394/96 (Lei de Diretrizes e Bases da Educação Nacional), em conformidade com o art. 22, XXIV, da Constituição Federal, por que se incumbiu a União de:

“Art. $9^{\circ}(\ldots)$

VI - assegurar processo nacional de avaliação do rendimento escolar no ensino fundamental, médio e superior, em colaboração com os sistemas de ensino, objetivando a definição de prioridades;

(...)

VIII - assegurar processo nacional de avaliação das instituições de educação superior, com a cooperação dos sistemas que tiverem responsabilidade sobre este nível de ensino;

(...)

IX - autorizar, reconhecer, credenciar, supervisionar e avaliar, respectivamente, os cursos das instituições de educação superior e os estabelecimentos do seu sistema de ensino;"

Ainda a disciplinar o direito à educação, foi instituído o Sistema Nacional de Avaliação da Educação Superior - SINAES (Lei n $\left.{ }^{\circ} 10.861 / 2004\right)$, que "tem por finalidades a melhoria da qualidade da educação superior, a orientação da expansão da sua oferta, o aumento permanente da sua eficácia institucional e efetividade acadêmica e social e, especialmente, a

${ }^{509}$ Cf. 1.3.1.1. 
promoção do aprofundamento dos compromissos e responsabilidades sociais das instituições de educação superior" $\left(\S 1^{\circ}\right.$ do art. $\left.1^{\circ}\right)$.

A fim de regulamentar a ordem jurídica nesses termos positivadas, o Presidente da República no exercício da atribuição que lhe confere o art. 84, IV, da Constituição Federal - editou o Decreto no $5.733 / 2006 . "$

Por essa razão, entendeu a corte que a Portaria MEC n ${ }^{\circ} 147$, de 2 de fevereiro de 2007, editada com base no Decreto $n^{\circ} 5.773 / 2006$, era válida, por configurar-se como regular exercício do poder regulamentar:

"Não há qualquer fundamento constitucional, legal ou infralegal de que se possa extrair direito
subjetivo a ser amparado nos presentes autos ou, ainda, abuso de poder do Ministro de Estado
da Educação na edição da Portaria n ${ }^{\circ} 147 / 2007$.
Trata-se de atuação legítima do Poder Executivo federal, competente para executar as funções
de regulação, supervisão e avaliação no âmbito do sistema federal de ensino, o qual
compreende "I - as instituições de ensino mantidas pela União; II - as instituições de
educação superior criadas e mantidas pela iniciativa privada; III - os órgãos federais de
educação" (art. 16 da Lei no 9.394/96)."

Pelo quadro apresentado, o estabelecimento do marco regulatório da educação superior tende a se consolidar, tendo em vista o fato do Poder Judiciário compreendê-lo como efetivação de normas constitucionais e legais que visam à condicionar a emissão de atos autorizativos à avaliação de qualidade.

\subsection{Projeto de Lei $n^{0}$ 4.372/2012: criação Instituto Nacional de Supervisão e Avaliação da Educação Superior - INSAES}

Por meio da Mensagem $\mathrm{n}^{\mathrm{o}}$ 398, de 31 de agosto de 2012, foi encaminhado ao Congresso Nacional, pela Presidenta da República, o Projeto de Lei no 4.372/2012, que pretende criar o Instituto Nacional de Supervisão e Avaliação da Educação Superior INSAES. A eventual aprovação desse projeto acarretará sensíveis alterações funcionais no sistema de avaliação, regulação e supervisão da educação superior.

No encaminhamento da proposta de projeto de lei à Presidenta da República, assinada pelos ministros de Estado do Planejamento, Orçamento e Gestão, da Educação e da Fazenda, foi ressaltado que, apesar da criação de uma secretaria específica no Ministério da Educação, a Secretaria de Regulação e Supervisão da Educação Superior - 
SERES, seria necessário o aperfeiçoamento institucional da atividade regulatória da educação superior, a fim de que sejam atingidas as metas estabelecidas no Plano Nacional de Educação atualmente em discussão no Congresso Nacional:

“9. Em que pese o importante passo dado pela criação da SERES, o desafio imposto ao MEC de atingir e manter elevado padrão de qualidade na educação superior ainda requer profundas alterações da atual estrutura do Ministério. É necessário o aprimoramento e atualização das estruturas de gestão, processos e sistemas de informação, para que se obtenha efetividade nas ações destinadas à qualidade vis-à-vis a ampliação quantitativa da rede de instituições de ensino e cursos por ela oferecidos e às necessidades da população e objetivos estratégicos do governo federal, o que implica na necessidade de uma ampliação significativa dos recursos humanos e financeiros disponíveis para o cumprimento das atribuições institucionais de avaliação, regulação e supervisão da educação superior." ${ }^{510}$

\section{E prosseguem:}

"11. Neste contexto, é apresentada a proposta de criação do Instituto Nacional de Supervisão e Avaliação da Educação Superior, que será responsável pelas atividades referentes à avaliação e supervisão das instituições de educação superior e cursos de graduação no sistema federal de ensino, bem como à certificação das entidades beneficentes que atuem na área de educação superior e básica.

\section{$[\ldots]$}

13. A integração em um único órgão das atividades de avaliação e supervisão da educação superior justifica-se não apenas pela maior otimização de recursos e integração de processos, mas também porque, de acordo com o Sistema Nacional de Avaliação da Educação Superior SINAES, a avaliação institucional externa de cursos e instituições de educação superior constitui referencial básico para os processos de regulação e supervisão da educação superior, para fins de emissão dos atos regulatórios de autorização, reconhecimento e renovação de reconhecimento dos cursos de graduação e credenciamento e recredenciamento de instituições. O exame de avaliação de desempenho de estudantes da educação superior, o Enade, continuará sob a responsabilidade do INEP.",511

É interessante notar que, apesar de ser mencionado o termo regulação em diversas passagens na proposta acima transcrita, o projeto de lei enviado pelo Congresso Nacional $^{512}$ não utiliza esse termo, pois pretende atribuir ao Instituto Nacional de

510 Exposição de motivos do Projeto de Lei $\mathrm{n}^{\mathrm{o}}$ 4.372/2012, item 9. Disponível em http://www.planalto.gov.br/ccivil_03/Projetos/ExpMotiv/EMI/2012/199\%20-\%20MP\%20MEC\%20MF.htm, acesso em 08.12.2012.

${ }_{511}$ Exposição de motivos do Projeto de Lei no ${ }^{\circ}$ 4.372/2012, itens 11 e 13.

512 Projeto de Lei $\mathrm{n}^{\circ}$ 4.372/2012. Disponível em http://www.camara.gov.br/proposicoesWeb/ prop_mostrarintegra;jsessionid=574C88D5271319DA5B21CACB0560EB16. node1 ?codteor $=1022352 \&$ filen ame $=\mathrm{PL}+4372 / 2012$, acesso em 08.12.2012 
Supervisão e Avaliação da Educação Superior - INSAES as competências de avaliação e supervisão da educação superior. Essa visão se coaduna com aquela que prevalece no âmbito da Casa Civil da Presidência da República, segundo a qual a regulação está presente apenas nas agências reguladoras de serviços públicos delegados, nas áreas de infraestrutura e na defesa da concorrência, expressa na estrutura e composição do Programa de Fortalecimento da Capacidade Institucional para Gestão em Regulação PRO-REG. ${ }^{513}$ A fim de consolidar o marco regulatório da educação superior, seria importante a alteração dessa concepção durante a tramitação do projeto de lei em questão no Congresso Nacional.

Talvez a modificação mais significativa a ser trazida pela criação do INSAES seja o estabelecimento de um quadro funcional próprio, qualificado e em número adequado - um dos principais problemas atualmente existentes no sistema regulatório da educação superior e que vem merendo atenção desproporcionalmente reduzida, em face de sua importância crucial. ${ }^{514} \mathrm{O}$ projeto de lei prevê a instituição do Plano de Carreiras e Cargos do INSAES no Quadro de Pessoal do INSAES, ${ }^{515}$ com a criação de trezentos e cinquenta cargos de Especialista em Avaliação e Supervisão da Educação Superior; cento e cinquenta cargos de Analista Administrativo; e cinquenta cargos de Técnico Administrativo. ${ }^{516}$

Edgar Gastón Jacobs entende que essa estruturação administrativa permitiria a efetiva ampliação da capacidade de avaliação in loco, fazendo com que o sistema de avaliação da educação superior se utilizasse mais desse mecanismo e menos dos indicadores de qualidade. ${ }^{517}$

Em caso de aprovação do projeto, a criação do INSAES, com competências que atualmente atribuídas ao MEC e ao INEP, promoverá significativas mudanças na configuração do sistema regulatório da educação superior. Seu estabelecimento por meio uma entidade autárquica e o estabelecimento de quadro técnico especializado próprio apontam no sentido próximo daquele que estabeleceu as agências reguladoras, embora essa denominação não tenha sido utilizada em razão do menor grau de autonomia de que gozará

\footnotetext{
${ }^{513}$ Cf. 3.3.1.

${ }^{514}$ Cf. Maria Paula Dallari Bucci, "Processo administrativo eletrônico e informação pública".

515 Projeto de Lei $\mathrm{n}^{\circ} 4.372 / 2012$, artigo $6^{\circ}$.

${ }^{516}$ Projeto de Lei $\mathrm{n}^{\circ} 4.372 / 2012$, artigo $9^{\circ}$.

${ }^{517}$ Cf. Edgar Gastón Jacobs, “Um instituto para regular o ensino superior”. Gestão Universitária 308 (2012). Disponível em http://www.gestaouniversitaria.com.br/index.php?option=com_content\&view=article\&id= 27233:um-instituto-para-regular-o-ensino-superior\&catid=316:308\&Itemid=21, acesso em 08.12.2012.
} 
em relação à administração indireta e do mencionado entendimento de que a atividade estatal sobre a educação superior não se trata de regulação. 


\section{Capítulo 5 PROCEDIMENTO ADMINISTRATIVO DE REGULAÇÃO DA EDUCAÇÃO SUPERIOR}

\subsection{Procedimentalização da atividade administrativa}

Em linhas gerais, a Constituição, a LDB e a Lei do SINAES fixaram os elementos fundamentais da atividade regulatória estatal em matéria educacional: (a) a necessidade dos atos administrativos regulatórios, de caráter autorizativo (autorização e o reconhecimento de cursos, bem como o credenciamento de instituições de educação superior); (b) o prazo limitado de tais atos, ensejando a necessidade de sua renovação periódica; (c) a existência do processo regular de avaliação para a expedição desses atos; (d) a possibilidade de saneamento de eventuais deficiências apontadas no processo de avaliação, durante um prazo determinado; e (e) a possibilidade da aplicação de sanções administrativas (desativação de cursos e habilitações, intervenção na instituição, suspensão temporária de prerrogativas da autonomia, ou descredenciamento, conforme o caso).

Nesses termos, a avaliação de qualidade deve ser provida de efeitos práticos e fundamentar a atividade regulatória. Para tanto, a regulação da educação superior pressupõe a estruturação de um procedimento administrativo que visa à produção de atos regulatórios de entrada no sistema e de permanência no sistema, que devem ser baseados na produção de indicadores e conceitos de qualidades aptos a fundamentar a decisão administrativa regulatória. Para tal finalidade, foi desenvolvida uma dinâmica processual administrativa que prevê a existência de um sistema eletrônico próprio, que, além de abrigar o desenvolvimento de um processo administrativo eletrônico, a ser desenvolvido em fases (instrução documental, avaliação, decisão e recurso), constitui-se, também, em banco de dados para subsidiar a atividade regulatória nessa área. Trata-se, assim, de um sistema que busca dotar o Poder Público de ferramentas processuais e de informações para a atividade regulatória, ao mesmo tempo em que se constitui em um mecanismo de garantia aos direitos do administrado no processo administrativo e a de accountability da atividade regulatória como um todo.

A organização da administração pública por meio do procedimento administrativo se desenvolveu muito nas últimas décadas, tendo como ponto de partida o 
estabelecimento do direito ao contraditório e à ampla defesa, com os meios e recursos a ela inerentes, aos envolvidos em processos administrativos, equiparando o ao direito existente nos processos judiciais. ${ }^{518}$

A partir de então estudo do Direito Administrativo passou a dar maior ênfase no processo administrativo, deixando o ato administrativo de figurar no centro dessa disciplina jurídica, conforme aponta Marçal Justen Filho:

"O conceito de ato administrativo perdeu a sua relevância como instrumento de compreensão e organização do direito administrativo. O fundamental está em considerar a atuação administrativa de modo global, não cada ato administrativo isoladamente.",519

O que se tem, assim, não é a diminuição da importância do ato administrativo, mas a compreensão de que este é o resultado final de um processo administrativo, no qual é garantido o direito ao contraditório e à ampla defesa a seus interessados. Esse fenômeno também é descrito por Maria Sylvia Zanella di Pietro, que, entre as tendências do Direito Administrativo contemporâneo, aponta as seguintes: (a) o fortalecimento da democracia participativa, com a previsão de inúmeros instrumentos de participação do cidadão no controle e na gestão de atividades da Administração Pública, mas com dificuldade de efetivação na prática; (b) a processualização do direito administrativo, especialmente com a exigência constitucional do devido processo legal. ${ }^{520}$

Esse fenômeno importou em colocar no centro da análise do Direito Administrativo a atividade administrativa, realizada por meio do processo administrativo, conforme aponta José Joaquim Gomes Canotilho: "a exigência de um procedimento juridicamente adequado para o desenvolvimento da actividade administrativa considera-se como dimensão insubstituível da administração do Estado de direito democrático". ${ }^{521}$ Marçal Justen Filho também a relação entre procedimentalização e atividade administrativa:

“A procedimentalização consiste na submissão das atividades administrativas à observância de procedimentos como requisito de validade das ações e omissões adotadas. Significa que a função administrativa se materializa em atividade administrativa, que é um conjunto de atos. Esse conjunto de atos deve observar uma sequência predeterminada, que assegure a

\footnotetext{
${ }^{518}$ Constituição da República Federativa do Brasil, artigo 5º LV.

${ }^{519}$ Marçal Justen Filho, Curso de Direito Administrativo, p. 293.

${ }^{520}$ Cf. Maria Sylvia Zanella di Pietro, Direito administrativo, p. 30.

${ }^{521}$ José Joaquim Gomes Canotilho, Direito constitucional e teoria da Constituição, pp. 274-275.
} 
possibilidade de controle do poder jurídico para realizar os fins de interesse coletivo e a promoção dos direitos fundamentais. ${ }^{, 522}$

Nesse sentido, a procedimentalização da atividade administrativa, em diversos segmentos, incorporou mecanismos de participação dos interessados, tendo em vista que a efetividade das políticas públicas demanda a participação de todos os interessados, diretos e indiretos, para a manifestação clara e transparente de todas as posições e alternativas em jogo. ${ }^{523}$ Esse aspecto é ainda mais relevante quando se trata de atividade regulatória potencialmente limitadora de direitos e interesses de partes no processo - que requer, portanto, um procedimento claro, que preveja a participação dos interessados, inclusive com o estabelecimento da necessidade de audiências públicas: ${ }^{524}$

“A regulação é um dos mais expressivos frutos das tendências contemporâneas do Direito Público para o aperfeiçoamento da decisão administrativa com vistas a que seja eficiente em seu desempenho e legitimada em seu resultado, superando assim as linhas tradicionais da administração burocrática de corte positivista, em que, tanto a eficiência como a legitimidade, não eram mais que referências secundárias e periféricas." ${ }^{~} 525$

No Brasil, o fenômeno da procedimentalização da atividade administrativa se intensificou a partir da edição de leis gerais de processo administrativo, produzidas pelos diferentes entes da Federação. Destacam-se a já citada Lei no 9.784/1999, aplicável à União, bem como a Lei Estadual $n^{\circ} 10.177$, de 30 de dezembro de 1998, aplicável à administração pública do Estado de São Paulo, que influenciaram a adoção de leis similares pelos demais integrantes da Federação. Mais recentemente, a Lei de Acesso à Informação, ${ }^{526}$ aplicável a todos os entes federados, ${ }^{527}$ veio a aprofundar essa tendência, regulando o acesso a informações públicas, pela adoção do princípio da publicidade máxima - o acesso à informação passa a ser regra, o sigilo a exceção.

Um importante aspecto a ser salientado é que, para desempenhar essas funções o Estado deve "preferencialmente, avançar paulatinamente na regulação desejada, de

\footnotetext{
${ }^{522}$ Marçal Justen Filho, Curso de Direito Administrativo, p. 296.

${ }^{523}$ Cf. Maria Paula Dallari Bucci, Direito Administrativo e políticas públicas, p. 269.

${ }^{524}$ Cf. Augustín Gordillo, "La regulación económica y social", p. 63.

${ }_{525}^{5}$ Diogo de Figueiredo Moreira Neto, Direito Regulatório, Rio de Janeiro: Renovar, 2003, p. 95.

${ }^{526}$ Lei $^{\circ}{ }^{\circ} 12.527 / 2011$.

527 É importante salientar que as disposições da Lei de Acesso à Informação são aplicáveis também às entidades privadas sem fins lucrativos que recebam, para realização de ações de interesse público, recursos públicos diretamente do orçamento ou mediante subvenções sociais, contrato de gestão, termo de parceria, convênios, acordo, ajustes ou outros instrumentos congêneres (artigo $2^{\circ}$ ).
} 
acordo com o princípio da permanente correção de erros (trial and error)", ${ }^{528}$ a ser exercido, nos termos da lei ou nos limites da discricionariedade conferida pela lei.

\subsection{Atos autorizativos}

A Lei de Diretrizes e Bases da Educação estabelece que a autorização e o reconhecimento de cursos, bem como o credenciamento de instituições de educação superior, terão prazos limitados, sendo renovados, periodicamente, após processo regular de avaliação. ${ }^{529}$ Trata-se de regulamentação legal do disposto no artigo 209 da Constituição, que prevê a autorização e avaliação de qualidade do poder público na atividade educacional. Tem-se, dessa maneira, a consagração do ato autorizativo como elemento fundamental da regulação desse setor, bem como de sua renovação periódica, a fim de permitir a avaliação do desenvolvimento da atividade educacional.

A atuação do Poder Público na regulação da educação superior é exercida por meio de um processo administrativo, desenvolvido eletronicamente, instituído por iniciativa do administrado interessado com a finalidade da emissão de um ato administrativo autorizativo, fundamentado na qualidade, tendo por base o relatório de avaliação e o conjunto de elementos de instrução apresentados pelas entidades interessadas no processo ou solicitados pelo Poder Público em sua atividade instrutória.

O Decreto $n^{\circ}$ 5.773/2006 promoveu a simplificação da dinâmica processual, com a unificação das referências conceituais das várias decisões tipificadas sob a nomenclatura atos autorizativos - que constituem de modalidades de autorização, no sentido que lhe empresta o Direito Administrativo - com a finalidade de unificar o regime de tramitação, excetuando apenas aspectos pontuais de cada tipo de ato. ${ }^{530}$ A noção de ato administrativo autorizativo mostra-se fundamental à compreensão da atividade regulatória neste setor, uma vez que fixa os limites da atuação dos agentes públicos e privados em matéria de educação superior. ${ }^{531}$ A centralidade do ato autorizativo na regulação da

\footnotetext{
${ }^{528}$ Alexandre Santos de Aragão, "Regulação da Economia: conceito e características contemporâneas", p. 420.

${ }^{529} \mathrm{LDB}$, art. 46.

${ }^{530}$ Cf. Maria Paula Dallari Bucci, "Processo administrativo eletrônico e informação pública".

${ }^{531} \mathrm{O}$ regime jurídico geral para todos os atos autorizativos está previsto no importante artigo 10, do Decreto $n^{\circ} 5.773 / 2006$ :

"Art. 10. O funcionamento de instituição de educação superior e a oferta de curso superior dependem de ato autorizativo do Poder Público, nos termos deste Decreto.
} 
educação superior é ilustrada pela disposição de que, em caso de divergência entre o ato autorizativo e qualquer documento de instrução do processo, prevalecerá o ato autorizativo, uma vez que este contém os elementos relevantes para o desempenho das atividades educacionais, cujas alterações dependem de modificação do ato autorizativo originário, a ser processada na forma de pedido de aditamento. ${ }^{532}$

Os atos autorizativos têm prazos limitados e devem ser renovados periodicamente, após processo regular de avaliação. Por essa razão, são modalidades de atos autorizativos os atos administrativos de entrada no sistema (credenciamento de instituição de educação superior e autorização de curso superior) e os de permanência no sistema (recredenciamento de instituição, bem como reconhecimento e renovação de reconhecimento de curso). Ressalte-se que o funcionamento de instituição ou a oferta de curso sem o devido ato autorizativo configura irregularidade administrativa, passível da aplicação de sanções dessa natureza, sem prejuízo dos efeitos da legislação civil e penal. ${ }^{53}$

Por essa razão, é fundamental o estudo do instituto jurídico da autorização administrativa. Em linhas gerais, o termo autorização é utilizado pelo Direito Administrativo em diferentes acepções. Maria Sylvia Zanella di Pietro apresenta da

$\S 1^{\circ}$ São modalidades de atos autorizativos os atos administrativos de credenciamento e recredenciamento de instituições de educação superior e de autorização, reconhecimento e renovação de reconhecimento de cursos superiores, bem como suas respectivas modificações.

$\S 2^{\circ}$ Os atos autorizativos fixam os limites da atuação dos agentes públicos e privados em matéria de educação superior.

$\S 3^{\circ}$ A autorização e o reconhecimento de cursos, bem como o credenciamento de instituições de educação superior, terão prazos limitados, sendo renovados, periodicamente, após processo regular de avaliação, nos termos da Lei no 10.861, de 14 de abril de 2004.

$\S 4^{\circ}$ Qualquer modificação na forma de atuação dos agentes da educação superior após a expedição do ato autorizativo, relativa à mantenedora, à abrangência geográfica das atividades, habilitações, vagas, endereço de oferta dos cursos ou qualquer outro elemento relevante para o exercício das funções educacionais, depende de modificação do ato autorizativo originário, que se processará na forma de pedido de aditamento.

$\S 5^{\circ}$ Havendo divergência entre o ato autorizativo e qualquer documento de instrução do processo, prevalecerá o ato autorizativo.

$\S 6^{\circ}$ Os prazos contam-se da publicação do ato autorizativo.

$\S 7^{\circ}$ Os atos autorizativos são válidos até o ciclo avaliativo seguinte. (Redação dada pelo Decreto $n^{\circ} 6.303$, de 2007)

$\S 8^{\circ} \mathrm{O}$ protocolo do pedido de recredenciamento de instituição de educação superior, de reconhecimento e de renovação de reconhecimento de curso superior prorroga a validade do ato autorizativo pelo prazo máximo de um ano.

$\S 9^{\circ}$ Todos os processos administrativos previstos neste Decreto observarão o disposto na Lei no 9.784 , de 29 de janeiro de 1999.

$\S 10$. Os pedidos de ato autorizativo serão decididos tendo por base o relatório de avaliação e o conjunto de elementos de instrução apresentados pelas entidades interessadas no processo ou solicitados pela Secretaria em sua atividade instrutória. (Incluído pelo Decreto $n^{\circ}$ 6.303, de 2007)".

${ }_{532}$ Decreto $^{\mathrm{o}} 5.773 / 2006$, art. 10 , caput, e $\$ \S 2^{\circ}, 4^{\mathrm{o}}, 5^{\circ}$ e 10.

${ }^{533}$ Decreto $^{\circ} 5.773 / 2006$, art. $10, \S 1^{\circ}$ e $3^{\circ}$; e art. 11 , caput. 
seguinte maneira a definição ampla do termo, em que a discricionariedade administrativa é um elemento comum:

"Pode-se portanto, definir a autorização administrativa, em sentido amplo, como o ato administrativo unilateral, discricionário e precário pelo qual a Administração faculta ao particular o uso de um bem público (autorização de uso), ou a prestação de serviço público (autorização de serviço público), ou o desenvolvimento de atividade material, ou a prática de ato que, sem esse consentimento, seriam legalmente proibidos (autorização como ato de polícia). ${ }^{, 534}$

Para Odete Medauar, a autorização administrativa vem exteriorizar uma manifestação do poder de polícia, baseado na discricionariedade, diferenciando-se, assim da licença administrativa: "a autorização apresenta-se como ato administrativo discricionário e precário, pelo qual a Administração consente no exercício de certa atividade; portanto, inexiste direito subjetivo à atividade." 535

Marçal Justen Filho aponta que, apesar da definição tradicional de autorização classificá-la como ato administrativo discricionário, cujo objeto seria o desenvolvimento de uma atividade privada, o exercício de um direito ou a constituição de uma situação de fato, caracterizada, desta maneira, pela precariedade e revogabilidade, atualmente há um problema que reside no fato de que o vocábulo autorização passou a ser utilizado em situações incompatíveis com as noções acima expostas. ${ }^{536}$

Passa-se agora a descrever os atos autorizativos da educação superior em espécie: credenciamento, recredenciamento, autorização, reconhecimento e renovação de reconhecimento.

Credenciamento é o ato autorizativo que condiciona o início de funcionamento de uma instituição de educação superior, de competência do Ministro de Estado da Educação, ao homologar deliberação a esse respeito do Conselho Nacional de Educação. ${ }^{537}$ Apesar das instituições de educação superior poderem, em tese, ser organizadas, de acordo com suas respectivas prerrogativas acadêmicas, como faculdades, centros universitários ou universidades, elas serão credenciadas originalmente como faculdade. ${ }^{538}$ Ressalte-se que o pedido de credenciamento de instituição de educação superior deverá tramitar em conjunto

\footnotetext{
${ }^{534}$ Maria Sylvia Zanella di Pietro, Direito administrativo, p. 234.

535 Odete Medauar, Direito administrativo moderno, p. 350.

${ }^{536}$ Marçal Justen Filho, Curso de Direito Administrativo, p. 377.

${ }^{537}$ Decreto no $^{\circ} 5.773 / 2006$, art. $4^{\circ}$, I; e art. 13, caput.

${ }^{538}$ Decreto no $^{\mathrm{o}} 5.773 / 2006$, art. 12. / Decreto n ${ }^{\circ} 5.773 / 2006$, art. $13, \S 1^{\text {o }}$.
} 
com pedido de autorização de pelo menos um curso superior. ${ }^{539}$ Por essa razão, antes de seu funcionamento, a instituição de ensino superior deve ter ao menos dois atos autorizativos de entrada no sistema: o de seu credenciamento e o de autorização de pelo menos um curso de graduação.

Recredenciamento é o ato autorizativo que renova os efeitos do ato de credenciamento, após regular processo de avaliação de qualidade. Ele deve ser requerido pela instituição ao final de cada ciclo avaliativo do SINAES. ${ }^{540}$

Autorização é o ato autorizativo que condiciona a oferta de cursos superiores em faculdade ou instituição equiparada, de competência do Secretário de Regulação e Supervisão da Educação Superior do Ministério da Educação. ${ }^{541}$ É importante ressaltar que a criação de cursos de graduação em direito e em medicina, odontologia e psicologia, inclusive em universidades e centros universitários, dependerá de autorização prévia do Ministério da Educação, após manifestação, respectivamente, do Conselho Federal da Ordem dos Advogados do Brasil ou do Conselho Nacional de Saúde. ${ }^{542}$ A instituição beneficiária de uma autorização tem o prazo de doze meses, a contar de sua publicação, para iniciar o funcionamento do curso, sob pena de caducidade. ${ }^{543}$

Reconhecimento é o ato autorizativo que tem por escopo a confirmação da possibilidade de oferta do curso superior, como condição necessária, juntamente com o registro, para a validade nacional dos respectivos diplomas. ${ }^{544}$ Desta maneira, trata-se de um complemento à autorização - enquanto esta tem por objeto de análise um projeto de curso, avaliando suas potencialidades, o reconhecimento avalia um curso em andamento, considerando sua situação real. No caso de um curso autorizado não apresentar condições qualitativas de funcionamento, por ocasião da avaliação para fins de reconhecimento, será emitido o ato administrativo de reconhecimento para fins de registro de diplomas, a fim de regularizar a situação dos alunos matriculados.

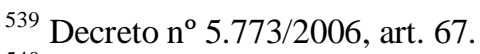

${ }^{540}$ Decreto $^{\circ}$ 5.773/2006, artigo 20, caput

${ }^{541}$ Decreto $^{\circ} 5.773 / 2006$, artigo 27, caput, artigo $5^{\circ}, \S 2^{\circ}$, II, $\S 3^{\circ}$, II e $\S 4^{\text {o }}$, II.

${ }^{542}$ Decreto no $^{\circ} 5.773 / 2006$, art. 28, $\S 2^{\circ}$.

${ }^{543}$ Decreto $^{\circ}$ 5.773/2006, art. 68, caput.

${ }^{544}$ Decreto no $^{\circ} 5.773 / 2006$, art. 34, caput.
} 
Renovação de reconhecimento é o ato autorizativo que renova os efeitos do ato de reconhecimento, após regular processo de avaliação de qualidade. A instituição deve requerê-lo ao final de cada ciclo avaliativo do SINAES. ${ }^{545}$

\subsection{Processo administrativo eletrônico: o Sistema e-MEC}

O contexto que ensejou a reconstrução do marco regulatório e a criação do sistema e-MEC caracterizava-se por problemas de toda ordem. Maria Paula Dallari Bucci aponta limitações no aparato burocrático regulatório que levaram à opção pelo processo administrativo eletrônico: (a) deficiências de pessoal e estrutura; (b) provisoriedade normativa; (c) fragmentação do processo decisório; (d) ausência de padrões de análise e decisão, conduzindo à necessidade de retrabalho e conduzindo à ineficiência; (e) baixa credibilidade e baixa efetividade das disposições regulatórias vigentes; e (f) ausência de transparência. O sistema existente à época - Sistema de Acompanhamento de Processos de Instituições de Ensino Superior (SAPIEnS) - apesar de simultaneamente eletrônico e em papel, era orientado segundo a lógica da tramitação em papel, devendo ser adaptado ou refeito a cada alteração normativa. ${ }^{546}$

A Portaria Normativa $n^{\circ}$ 40/2007 institui o Sistema e-MEC - sistema eletrônico de fluxo de trabalho e gerenciamento de informações relativas aos processos de regulação da educação superior no sistema federal de educação. ${ }^{547} \mathrm{O}$ intuito do e-MEC é o de simplificar, racionalizar e abreviar o trâmite dos processos relacionados à avaliação, regulação (em sentido estrito) e supervisão dos cursos superiores, utilizando ao máximo as possibilidades oferecidas pela tecnologia da informação. Além disso, esse sistema busca procedimentalização da atividade regulatória da educação superior, a fim de, por um lado, garantir o direito das partes interessadas e, por outro, racionalizar o desempenho dessa atividade, para obter maior efetividade nas políticas públicas implementadas por meio da regulação e aumentar a possibilidade de controle social dessa atividade.

É importante frisar que, por se tratar de processo desenvolvido eletronicamente, são aplicáveis, por analogia, as disposições da Lei no 11.419/2006, que

\footnotetext{
${ }_{545}^{54}$ Decreto $^{\circ} 5.773 / 2006$, artigo 41, caput.

${ }^{546}$ Cf. Maria Paula Dallari Bucci, "Processo administrativo eletrônico e informação pública".

${ }^{547}$ Cf. 4.5.2.
} 
dispõe sobre a informatização do processo judicial ${ }^{548}$ e, subsidiariamente, as disposições da Lei $\mathrm{n}^{\circ}$ 9.784/1999, que regula o processo administrativo no âmbito da Administração Pública Federal. ${ }^{549}$

Os documentos que integram o e-MEC são, via de regra, públicos, com exceção das informações de exclusivo interesse privado das instituições de educação superior, expressamente previstos na Portaria Normativa $n^{\circ} 40 / 2007 .{ }^{550}$ A interpretação do conteúdo das informações de exclusivo interesse privado devem se compatibilizar com o as disposições contidas na Lei de Acesso à Informação. ${ }^{551}$

Nos processos de avaliação, regulação (em sentido estrito) e supervisão da educação superior em tramitação no e-MEC, as notificações e publicações dos atos de tramitação dos processos serão feitas exclusivamente em meio eletrônico, e a movimentação dos processos se fará mediante a utilização de certificados digitais, padrão ICP Brasil. ${ }^{552}$ A contagem de prazos no e-MEC observa o disposto no artigo 66 da Lei $n^{\circ}$ 9.784/1999, em dias corridos, excluindo-se o dia da abertura da vista e incluído-se o do vencimento, levando em consideração o horário de disponibilidade do sistema, que será devidamente informado aos usuários, sendo que em caso de indisponibilidade do sistema na data de vencimento de qualquer prazo ocorre a prorrogação automática deste para o primeiro dia subsequente em que haja novamente a disponibilidade. É importante ressaltar que a não utilização do prazo pelo interessado acarreta preclusão, desencadeando o restabelecimento do fluxo processual. Como forma de garantir o controle adequado da marcha do processo, é gerado um registro e correspondente número para cada transação, mantendo informação de andamento processual própria. ${ }^{553}$

No âmbito das instituições de educação superior, deve ser indicado profissional que exercerá a função de Procurador Educacional Institucional (PI), que será o responsável pelas informações no Cadastro e-MEC e nos processos regulatórios correspondentes, bem como pelos elementos de avaliação, incluídas as informações necessárias à realização do ENADE. Para tanto, o Procurador Educacional Institucional deverá ser investido de poderes para prestar informações em nome da instituição, por ato

\footnotetext{
${ }^{548}$ Portaria Normativa $\mathrm{n}^{\mathrm{o}} 40 / 2007$, art. $1^{\mathrm{o}}$.

${ }^{549}$ Lei 9784/1999, art. 69.

${ }^{550}$ Portaria Normativa $\mathrm{n}^{\circ} 40 / 2007$, art. $3^{\circ}$, caput.

${ }^{551}$ Lei no $12.527 / 2011$.

${ }^{552}$ Portaria Normativa $n^{\circ} 40 / 2007$, art. $2^{\circ}$

${ }^{553}$ Portaria Normativa $n^{\circ} 40 / 2007$, art. $1^{\circ}, \S \S 3^{\circ}$ a $6^{\circ}$.
} 
de seu representante legal ao identificá-lo no sistema e-MEC, articulando-se, na instituição, com os responsáveis pelos demais sistemas de informações do Ministério da Educação, podendo indicar Auxiliares Institucionais (AI) para compartilhar tarefas de inserção de dados, sob sua responsabilidade, uma vez que as informações prestadas presumem-se válidas para todos os efeitos legais. ${ }^{554}$

O Procurador Educacional Institucional configura-se como um elemento de suma importância no âmbito das instituições, uma vez que esse profissional deve estabelecer a relação institucional com o sistema de avaliação, regulação e supervisão, tanto em questões administrativas quanto em acadêmicas. Por essa razão, esse profissional deverá, preferencialmente, estar ligado à Reitoria ou à Pró-Reitoria de Graduação da instituição ou a órgãos equivalentes, a fim de que a comunicação com os órgãos do MEC esteja coordenada com as políticas, procedimentos e dados da instituição no seu conjunto. $^{555}$

A Portaria Normativa $n^{\circ} 23 / 2010$, que alterou a Portaria Normativa $n^{\circ} 40 / 2007$, trouxe importantes medidas relacionadas à gestão de informações necessárias para o desenvolvimento da atividade regulatória da educação superior: a criação do Cadastro eMEC e do Cadastro Nacional de Docentes.

A regulamentação do gerenciamento de informações relativas aos processos de avaliação, regulação (em sentido estrito) e supervisão da educação superior no sistema federal de educação foi realizada por meio da criação do Cadastro e-MEC, ${ }^{556}$ cujo intuito é o de permitir a informação ao público sobre o andamento dos processos, bem como a relação de instituições credenciadas e de cursos autorizados e reconhecidos, além dos dados sobre os atos autorizativos e os elementos relevantes da instrução processual, ${ }^{557}$ além de indicadores de qualidade. Os dados que integram o Cadastro e-MEC são públicos, com as ressalvas previstas na legislação. ${ }^{558}$ Dessa maneira, além de atender ao princípio da publicidade, propiciando o controle social da atividade regulatória do Poder Público federal e a permitir a difusão de informações ao público em geral, diminuição a assimetria de informações prejudicial ao atendimento de índices de qualidade satisfatórios.

\footnotetext{
${ }^{554}$ Portaria Normativa $n^{\circ} 40 / 2007$, art. 61-E, caput e $\$ \S 2^{\circ}$ a $4^{\circ}$.

${ }_{555}^{5}$ Portaria Normativa ${ }^{\circ} 40 / 2007$, art. 61-E, $\S 1^{\circ}$.

${ }_{556} \mathrm{O}$ Cadastro e-MEC pode ser consultado na página eletrônica http://emec.mec.gov.br/.

${ }^{557}$ Portaria Normativa $\mathrm{n}^{\circ} 40 / 2007$, art. $4^{\circ}$.

${ }^{558}$ Portaria Normativa n ${ }^{\circ} 40 / 2007$, art. 61-A, $\S 1^{\text {o }}$.
} 
Dessa maneira, as informações contidas no Cadastro e-MEC constituem a base de dados de referência a ser utilizada pelos órgãos que detém competência regulatória relativa à educação superior, prevalecendo sobre quaisquer outras bases, sendo que seus arquivos e registros digitais são válidos para todos os efeitos legais e permanecerão à disposição das auditorias internas e externas, em que se manterá histórico de atualizações e alterações. $^{559}$

O Cadastro e-MEC relaciona-se diretamente aos processos de avaliação, regulação (em sentido estrito) e supervisão, uma vez que atribui para cada instituição, curso e local de oferta de educação superior um código próprio, a ser utilizado nos demais sistemas eletrônicos do MEC, considerando como curso individualizado aquele que possui projeto pedagógico próprio, independentemente de eventual compartilhamento de disciplinas, percursos formativos ou formas de acesso entre eles. A existência de códigos próprios para instituições e cursos tem o intuito de estruturar o sistema para propiciar a interoperabilidade com os demais sistemas e programas do MEC, ${ }^{560}$ embora esse processo ainda esteja em curso.

Os dados do Cadastro e-MEC, dessa maneira, devem guardar conformidade com os atos autorizativos das instituições e cursos de educação superior, editados com base nos processos regulatórios. ${ }^{561}$ Por essa razão, a alteração dos dados constantes do Cadastro e-MEC depende de aditamento ou atualização dos atos autorizativos correspondentes, na forma das normas que regem o processo regulatório. No âmbito do MEC, a responsabilidade pela orientação e gestão do Cadastro e-MEC caberá à Secretaria de Regulação e Supervisão da Educação Superior, que procederá a inserção de informações das instituições e cursos de educação superior. ${ }^{562}$

O Cadastro Nacional de Docentes foi instituído para constituir-se na base de dados oficial sobre os docentes vinculados às instituições de ensino superior, com precedência sobre outros repositórios de informações sobre professores da educação superior no âmbito do MEC e autarquias vinculadas. ${ }^{563}$ Suas informações são de responsabilidade das instituições, que deverão proceder a sua atualização e validação dos dados periodicamente ou quando solicitadas pelos órgãos do MEC ou autarquias

\footnotetext{
${ }^{559}$ Portaria Normativa $n^{\circ} 40 / 2007$, art. 61-A, $\S \S 5^{\circ}$ e $7^{\circ}$.

${ }^{560}$ Portaria Normativa ${ }^{\circ} 40 / 2007$, art. 61-A, $\$ \S 2^{\circ}$ a $4^{\circ}$.

${ }^{561}$ Portaria Normativa $\mathrm{n}^{\circ}$ 40/2007, art. 61-B.

${ }^{562}$ Portaria Normativa n ${ }^{\circ} 40 / 2007$, art. 61-F.

${ }^{563}$ Portaria Normativa no 40/2007, art. 61-G.
} 
vinculadas. Dessa maneira, o Cadastro Nacional de Docentes deve ser alimentado com a identificação de cada indivíduo pelo número de seu registro no Cadastro de Pessoas Físicas (CPF), a fim de evitar duplicidades. ${ }^{564}$ Por essa razão, esse cadastro pode vir a ser um importante instrumento na atividade regulatória da educação superior, permitindo a imediata verificação de possíveis irregularidades concernentes a excesso de vínculos de um mesmo docente.

Por outro lado, as informações relativas aos estudantes coletadas pelo Censo da Educação Superior, a cargo do Instituto Nacional de Estudos e Pesquisas Educacionais Anísio Teixeira (INEP), constituem a base de dados de referência a ser utilizada pelos órgãos do MEC e autarquias vinculadas para fins regulatórios, com precedência sobre quaisquer outras. ${ }^{565}$ Esses dados, a exemplo do que ocorre com os dos docentes, devem ser registrados por indivíduo, identificado pelo número de registro no Cadastro de Pessoas Físicas (CPF), a fim de evitar duplicidades. Dessa maneira, o cadastro de estudantes também pode constituir uma ferramenta útil, em especial no processo de supervisão, tendo em vista sua capacidade de identificar possíveis expedições irregulares de diplomas.

O procedimento regulatório da educação superior no Brasil é desenvolvido eletronicamente por meio do Sistema e-MEC, iniciando-se por meio da provocação, por parte do interessado, da instauração do procedimento administrativo de credenciamento, ${ }^{566}$ recredenciamento, ${ }^{567}$ autorização, ${ }^{568}$ reconhecimento, ${ }^{569}$ ou renovação de reconhecimento, ${ }^{570}$ bem como do pagamento da taxa de avaliação. A instituição de educação, além disso, deve instruir o pedido com a documentação exigida para a espécie de procedimento solicitada. Após a execução de tais medidas preliminares, a instituição interessada obtêm o protocolo eletrônico do processo. ${ }^{571}$

Após a obtenção do protocolo eletrônico, a atividade administrativa regulatória da educação superior passa a se desenvolver sob a responsabilidade do Poder Público, por meio de um procedimento trifásico, que abrange: (a) análise documental; (b) avaliação; e (c) decisão administrativa. Cada uma das fases - as duas primeiras de caráter instrutório e

\footnotetext{
${ }_{565}^{564}$ Portaria Normativa n ${ }^{\circ} 40 / 2007$, art. 61-H, parágrafo único.

${ }^{565}$ Portaria Normativa ${ }^{\circ}$ 40/2007, art. 61-H, caput.

${ }^{566}$ Decreto $^{\circ}$ 5.773/2006, art. 14, I.

${ }^{567}$ Decreto no $^{\circ} 5.773 / 2006$, art. 20.

${ }^{568}$ Decreto n $^{\circ} 5.773 / 2006$, art. 29, I.

${ }^{569}$ Decreto no $^{\circ} 5.773 / 2006$, art. 35 .

${ }^{570}$ Decreto no $^{\circ} 5.773 / 2006$, art. 41, caput.

${ }^{571}$ Portaria Normativa $n^{\circ} 40 / 2007$, art. $8^{\circ}$.
} 
a última, decisório - apresenta a possibilidade de formulação de recurso administrativo. Frise-se também que, ao iniciar o trâmite em uma dessas fases, não há a possibilidade de retorno à tramitação da fase anterior.

A atividade de avaliação, como expressão do poder de polícia estatal, enseja a cobrança da taxa de avaliação in loco, em favor do INEP, quando formulada solicitação de credenciamento ou renovação de credenciamento de instituição de educação superior e solicitação de autorização, reconhecimento ou renovação de reconhecimento de cursos de graduação. ${ }^{572}$ As receitas obtidas por meio deste tributo serão aplicadas exclusivamente no custeio das despesas com as comissões de avaliação. ${ }^{573}$

A taxa de avaliação in loco é fixada no valor de $\mathrm{R} \$ 6.960,00$ (seis mil, novecentos e sessenta reais), com o acréscimo de R $\$ 3.480,00$ (três mil, quatrocentos e oitenta reais) por avaliador acrescentado à composição básica da comissão de avaliação, que será de 2 (dois) membros. ${ }^{574} \mathrm{~A}$ taxa deverá recolhida ao INEP na oportunidade em que for solicitado credenciamento ou renovação de credenciamento de instituição de educação superior e autorização, reconhecimento ou renovação de reconhecimento de cursos de graduação, devendo ser paga uma taxa de avaliação pro processo aberto no Sistema eMEC. ${ }^{575}$ A criação da taxa de avaliação in loco, da qual são contribuintes as instituições de educação superior privadas e públicas, reforça a dimensão de poder de polícia existente na regulação da educação superior.

$\mathrm{Na}$ hipótese de arquivamento do processo ou dispensa de avaliação in loco, poderá ser gerado crédito do valor da taxa de avaliação correspondente em favor do requerente caso não tenham sido efetuadas despesas de custeio pelo INEP, podendo ser reaproveitado no sistema e-MEC em outra avaliação da instituição ou de seus cursos. ${ }^{576}$

\subsection{Competências administrativas}

A fim de desenvolver a atividade regulatória do sistema federal de educação superior, foi estruturado um sistema que compreende a distribuição de competências entre diversos órgãos e autarquias do Ministério da Educação (MEC), com a colaboração de

\footnotetext{
${ }^{572}$ Lei n ${ }^{\circ} 10.870 / 2004$, art. $1^{\circ}$, caput.

${ }^{573}$ Lei $\mathrm{n}^{\mathrm{o}} 10.870 / 2004$, art. $3^{\mathrm{o}}, \S 3^{\mathrm{o}}$.

${ }^{574}$ Lei $\mathrm{n}^{\mathrm{o}} 10.870 / 2004$, art. $3^{\mathrm{o}}$, caput e $\S 1^{\circ}$.

${ }^{575}$ Portaria Normativa n ${ }^{\circ} 40 / 2007$, art. 14-A, caput.

${ }^{576}$ Portaria Normativa $n^{\circ} 40 / 2007$, art. 14-B, caput e $\S 1^{\circ}$.
} 
outras entidades. No âmbito do Ministério da Educação, o sistema regulatório da educação superior confere competências ao Ministro de Estado da Educação, à Secretaria de Regulação e Supervisão da Educação Superior (SERES), ao Conselho Nacional de Educação (CNE), à Comissão Nacional de Avaliação da Educação Superior (CONAES), bem como ao Instituto Nacional de Estudos e Pesquisas Educacionais Anísio Teixeira (INEP), autarquia vinculada ao MEC. ${ }^{577}$

\subsubsection{Ministro de Estado da Educação}

Ao Ministro de Estado da Educação, autoridade máxima da educação superior no sistema federal de ensino, compete: (a) homologar deliberações do CNE em pedidos de credenciamento e recredenciamento de instituições de educação superior; (b) homologar os instrumentos de avaliação elaborados pelo INEP; (c) homologar os pareceres da CONAES; (d) homologar pareceres e propostas de atos normativos aprovados pelo Conselho Nacional de Educação; e (e) expedir normas e instruções para a execução de leis, decretos e regulamentos. 578

\subsubsection{Conselho Nacional de Educação (CNE)}

O Conselho Nacional de Educação (CNE), órgão colegiado integrante da estrutura de administração direta do Ministério da Educação, ${ }^{579}$ foi criado pela Lei $\mathrm{n}^{\mathrm{o}}$ 9.131/1995, ${ }^{580}$ em substituição ao antigo Conselho Federal de Educação. O CNE é um importante órgão para a regulamentação da educação brasileira, sucessor dos seguintes órgãos: Conselho de Instrução Superior (criado em 1891), o Conselho Superior do Ensino (criado em 1911), o Conselho Nacional de Ensino (CNEn - criado em 1925), o antigo Conselho Nacional de Educação (CNE - criado em 1931), o Conselho Federal de Educação (CFE - criado em 1961) e, finalmente, o atual CNE. ${ }^{581}$

\footnotetext{
${ }^{577}$ Decreto $^{\circ} 5.773 / 2006$, arts. $3^{\circ}$ a $8^{\circ}$.

${ }^{578}$ Decreto $^{\circ} 5.773 / 2006$, art. $4^{\circ}$.

${ }^{579}$ Lei $\mathrm{n}^{\circ} 10.683$, de 28 de maio de 2003, artigo 29, X.

${ }^{580}$ A Lei ${ }^{\circ}$ 9.131/1995, que criou o CNE, unicamente introduziu alterações na antiga Lei de Diretrizes e

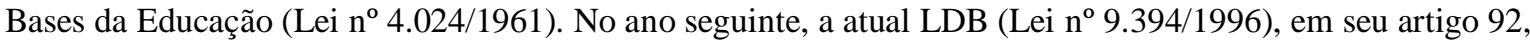
revogou parcialmente a antiga $\mathrm{LDB}$, mantendo expressamente alguns dispositivos, dentre os quais aqueles introduzidos pela Lei ${ }^{\circ}$ 9.131/1995.

${ }^{581}$ Cf. Magno Federici Gomes, "Educação superior privada como serviço de utilidade pública”, p. 275.
} 
Os membros do Conselho Nacional de Educação - tanto os que integram a Câmara de Educação Básica como a Câmara de Educação Superior - são nomeados pelo Presidente da República, com exceção de seus dois membros natos, integrantes do Ministério da Educação. ${ }^{582}$ A fim de permitir a participação social no processo de escolha dos conselheiros, está deve ser feita obrigatoriamente dentre os indicados em listas elaboradas especialmente para cada uma das câmaras, mediante consulta a entidades da sociedade civil, relacionadas às áreas de atuação dos respectivos colegiados. ${ }^{583}$ Especificamente em relação à Câmara de Educação Superior - que tem a competência da regulação nesse nível - a consulta deve envolver indicações formuladas por entidades nacionais, públicas e particulares, que congreguem os reitores de universidades, diretores de instituições isoladas, os docentes, os estudantes e segmentos representativos da comunidade científica. Os conselheiros do CNE têm mandato de quatro anos, sendo permitida uma recondução para o período imediatamente subsequente, havendo renovação de metade das Câmaras a cada dois anos. ${ }^{584}$

No que diz respeito à avaliação, regulação e supervisão da educação superior, compete ao CNE: (a) exercer atribuições normativas, deliberativas e de assessoramento do Ministro de Estado da Educação; (b) deliberar, com base no parecer da Secretaria de Regulação e Supervisão da Educação Superior (SERES), sobre pedidos de credenciamento e recredenciamento de instituições de educação superior e específico para a oferta de cursos de educação superior a distância; (c) recomendar, por sua Câmara de Educação Superior, providências da SERES, entre as quais a celebração de protocolo de compromisso, quando não satisfeito o padrão de qualidade específico para credenciamento e recredenciamento de universidades, centros universitários e faculdades; (d) deliberar sobre as diretrizes propostas pela SERES para a elaboração, pelo INEP, dos instrumentos de avaliação para credenciamento de instituições; (e) aprovar os instrumentos de avaliação para credenciamento de instituições, elaborados pelo INEP; (f) deliberar, por sua Câmara de Educação Superior, sobre a exclusão de denominação de curso superior de tecnologia do catálogo de denominações; (g) aplicar penalidades; (h) julgar recursos, nas hipóteses previstas neste Decreto; (i) analisar questões relativas à aplicação da legislação da

\footnotetext{
${ }^{582}$ Lei $n^{\circ} 4.024 / 1961$, com redação dada pela Lei $n^{\circ} 9.131 / 1995$, artigo $8^{\circ}$, caput.

${ }^{583}$ Lei $^{\circ}$ 4.024/1961, com redação dada pela Lei $n^{\circ} 9.131 / 1995$, artigo $8^{\circ}$, $\S 1^{\circ}$.

${ }^{584}$ Lei $n^{\circ} 4.024 / 1961$, com redação dada pela Lei $n^{\circ} 9.131 / 1995$, artigo $8^{\circ}, \S 6^{\circ}$.
} 
educação superior; e (j) orientar sobre os casos omissos na aplicação do Decreto $\mathrm{n}^{\mathrm{o}}$ $5.773 / 2006$, ouvido o órgão de consultoria jurídica do Ministério da Educação. ${ }^{585}$

\subsubsection{Comissão Nacional de Avaliação da Educação Superior (CONAES)}

A Comissão Nacional de Avaliação da Educação Superior (CONAES) é um órgão colegiado, vinculado ao Gabinete do Ministro da Educação, para a coordenação e supervisão do Sistema Nacional de Avaliação da Educação Superior (SINAES), criado pela Lei $\mathrm{n}^{\mathrm{o}}$ 10.861/2004, tendo as seguintes atribuições: (a) propor e avaliar as dinâmicas, procedimentos e mecanismos da avaliação institucional, de cursos e de desempenho dos estudantes; (b) estabelecer diretrizes para organização e designação de comissões de avaliação, analisar relatórios, elaborar pareceres e encaminhar recomendações às instâncias competentes; (c) formular propostas para o desenvolvimento das instituições de educação superior, com base nas análises e recomendações produzidas nos processos de avaliação; (d) articular-se com os sistemas estaduais de ensino, visando a estabelecer ações e critérios comuns de avaliação e supervisão da educação superior; (e) submeter anualmente à aprovação do Ministro da Educação a relação dos cursos a cujos estudantes será aplicado o Exame Nacional de Desempenho dos Estudantes (ENADE); (f) elaborar o seu regimento, a ser aprovado em ato do Ministro da Educação; e (g) realizar reuniões ordinárias mensais e extraordinárias, sempre que convocadas pelo Ministro de Estado da Educação. ${ }^{586}$

O Decreto $\mathrm{n}^{\mathrm{o}} 5.773 / 2006$ buscou conferir maior grau de detalhamento às atribuições da CONAES, conferindo-lhe ainda, as seguintes competências não expressas na Lei do SINAES: (a) estabelecer diretrizes para a elaboração, pelo INEP, dos instrumentos de avaliação de cursos de graduação e de avaliação interna e externa de instituições; (b) estabelecer diretrizes para a constituição e manutenção do banco público de avaliadores especializados; (c) aprovar instrumentos de avaliação e submetê-los à homologação pelo Ministro da Educação; (d) avaliar anualmente as dinâmicas, procedimentos e mecanismos da avaliação institucional, de cursos e de desempenho dos estudantes do SINAES; (e) estabelecer diretrizes para organização e designação de comissões de avaliação, analisar relatórios, elaborar pareceres e encaminhar recomendações às instâncias competentes; (f) ter acesso a dados, processos e resultados da avaliação; e (g) submeter anualmente, para

\footnotetext{
${ }^{585}$ Decreto n $^{\circ} 5773 / 2006$, art. $6^{\circ}$.

${ }^{586}$ Lei do SINAES, artigo $6^{\circ}$.
} 
fins de publicação pelo Ministério da Educação, relatório com os resultados globais da avaliação do SINAES. $^{587}$

Assim como o CNE, a CONAES também busca, por meio de sua composição, conferir participação social em suas atividades, sendo sua composição mais vinculada do que a do CNE, contando com: (a) um representante do INEP; (b) um representante da Fundação Coordenação de Aperfeiçoamento de Pessoal de Nível Superior - CAPES; (c) três representantes do Ministério da Educação, sendo um obrigatoriamente do órgão responsável pela regulação e supervisão da educação superior; (d) um representante do corpo discente das instituições de educação superior; (e) um representante do corpo docente das instituições de educação superior; (f) um representante do corpo técnicoadministrativo das instituições de educação superior; e (g) cinco membros, indicados pelo Ministro da Educação, escolhidos entre cidadãos com notório saber científico, filosófico e artístico, e reconhecida competência em avaliação ou gestão da educação superior. ${ }^{588} \mathrm{O}$ representante do corpo discente é nomeado pelo Presidente da República para mandato de dois anos, vedada a recondução. Os demais membros não integrantes natos dos órgãos e entidades governamentais são nomeados pelo Presidente da República para mandato de três anos, admitida uma recondução. ${ }^{589}$

\subsubsection{Instituto Nacional de Estudos e Pesquisas Educacionais Anísio Teixeira (INEP)}

O Instituto Nacional de Estudos e Pesquisas Educacionais Anísio Teixeira (INEP) foi transformado em autarquia federal vinculada ao Ministério da Educação pela Lei $\mathrm{n}^{\circ}$ 9.448, de 14 de março de 1997, tendo por finalidades: (a) organizar e manter o sistema de informações e estatísticas educacionais; (b) planejar, orientar e coordenar o desenvolvimento de sistemas e projetos de avaliação educacional, visando ao estabelecimento de indicadores de desempenho das atividades de ensino no País; (c) apoiar os Estados, o Distrito Federal e os Municípios no desenvolvimento de sistemas e projetos de avaliação educacional; (d) desenvolver e implementar, na área educacional, sistemas de informação e documentação que abranjam estatísticas, avaliações educacionais, práticas pedagógicas e de gestão das políticas educacionais; (e) subsidiar a formulação de políticas

\footnotetext{
${ }^{587}$ Decreto $^{\circ}$ 5.773/2006, artigo $8^{\circ}$.

${ }^{588}$ Lei do SINAES, artigo $7^{\circ}$, caput.

${ }^{589}$ Lei do SINAES, artigo $7^{\circ}, \S \S 2^{\circ}$ e $3^{\circ}$.
} 
na área de educação, mediante a elaboração de diagnósticos e recomendações decorrentes da avaliação da educação básica e superior; (f) coordenar o processo de avaliação dos cursos de graduação, em conformidade com a legislação vigente; (g) definir e propor parâmetros, critérios e mecanismos para a realização de exames de acesso ao ensino superior; (h) promover a disseminação de informações sobre avaliação da educação básica e superior; e (i) articular-se, em sua área de atuação, com instituições nacionais, estrangeiras e internacionais, mediante ações de cooperação institucional, técnica e financeira bilateral e multilateral. ${ }^{590}$

No que diz respeito à avaliação, regulação e supervisão da educação superior, compete ao INEP: (a) realizar visitas para avaliação in loco nos processos de credenciamento e recredenciamento de instituições de educação superior e nos processos de autorização, reconhecimento e renovação de reconhecimento de cursos de graduação e seqüenciais; (b) realizar as diligências necessárias à verificação das condições de funcionamento de instituições e cursos, como subsídio para o parecer da Secretaria de Regulação e Supervisão da Educação Superior, quando solicitado; (c) realizar a avaliação das instituições, dos cursos e do desempenho dos estudantes; (d) elaborar os instrumentos de avaliação conforme as diretrizes da CONAES; (e) elaborar os instrumentos de avaliação para credenciamento de instituições e autorização de cursos, conforme as diretrizes do CNE e da Secretaria de Regulação e Supervisão da Educação Superior, conforme o caso; e (f) constituir e manter banco público de avaliadores especializados, conforme diretrizes da CONAES. ${ }^{591}$

No âmbito do INEP, essas atribuições são desempenhadas pela Diretoria de Avaliação da Educação Superior, ${ }^{592}$ a quem compete, de forma mais específica: (a) propor, planejar, programar e coordenar ações voltadas à avaliação dos cursos e instituições de educação superior, articulando-se com os sistemas federal e estaduais de ensino; (b) definir e propor parâmetros, critérios e mecanismos para a realização do Exame Nacional de Desempenho dos Estudantes - ENADE, bem como coordenar o processo de consolidação e divulgação dos resultados e produtos; (c) organizar e capacitar o Banco de Avaliadores do Sistema Nacional de Avaliação da Educação Superior; (d) propor a realização de

\footnotetext{
${ }^{590}$ Lei $\mathrm{n}^{\circ} 9.448 / 1997$, art. $1^{\circ}$.

${ }^{591}$ Decreto $^{\circ} 5.773 / 2006$, artigo $7^{\circ}$.

${ }^{592}$ A Diretoria de Avaliação da Educação Superior é composta por três Coordenações-Gerais: CoordenaçãoGeral de Avaliação dos Cursos de Graduação e Instituições de Ensino Superior, Coordenação-Geral de Controle de Qualidade da Educação Superior e Coordenação-Geral do ENADE (Decreto n ${ }^{\circ}$ 6.317/2006, Anexo II, com redação dada pelo Decreto nº 7.693, de 2 de março de 2012).
} 
avaliações internacionais da educação superior, em articulação com organismos estrangeiros e internacionais; e (e) coordenar a elaboração dos instrumentos de avaliação da Educação Superior, segundo as diretrizes da Comissão Nacional de Avaliação da Educação Superior e da Secretaria de Regulação e Supervisão da Educação Superior $(\mathrm{SERES}){ }^{593}$

\subsubsection{Secretaria de Regulação e Supervisão da Educação Superior (SERES)}

A Secretaria de Regulação e Supervisão da Educação Superior (SERES) foi criada pelo Decreto $\mathrm{n}^{\mathrm{o}} 7.480$, de 16 de maio de $2011,{ }^{594}$ que atribuiu a essa secretaria competências regulatórias que anteriormente pertenciam a outras três secretarias: Secretaria de Educação Superior (SESu), Secretaria de Educação Profissional e Tecnológica (SETEC) e Secretaria de Educação a Distância (SEED). Por essa razão, as competências atribuídas a essas três secretarias em matéria regulatória por normas anteriores à criação da SERES devem ser exercidas por esta.

Compete à SERES: ${ }^{595}$ (a) planejar e coordenar o processo de formulação de políticas para a regulação e supervisão da educação superior, em consonância com as metas do PNE; (b) autorizar, reconhecer e renovar o reconhecimento de cursos de graduação e sequenciais, presenciais e a distância; (c) exarar parecer nos processos de credenciamento e recredenciamento de instituições de educação superior para as modalidades presencial e a distância; (d) supervisionar instituições de educação superior e cursos de graduação e sequenciais, presenciais e a distância, com vistas ao cumprimento da legislação educacional e à indução de melhorias dos padrões de qualidade da educação superior, aplicando as penalidades previstas na legislação; (e) estabelecer diretrizes e instrumentos para as ações de regulação e supervisão da educação superior, presencial e a distância em consonância com o ordenamento legal vigente; (d) estabelecer diretrizes para a elaboração dos instrumentos de avaliação de instituições e cursos de educação superior; (e) gerenciar sistema público de informações cadastrais de instituições e cursos de educação superior; (f) gerenciar sistema eletrônico de acompanhamento de processos

\footnotetext{
${ }^{593}$ Decreto $^{\circ}$ 6.317/2006, Anexo I, artigo 11.

594 Atualmente, as competências dos órgãos do MEC são definidas pelo Decreto no 7690 , de 2 de março de 2012, que revogou o Decreto $\mathrm{n}^{\mathrm{o}} 7.480 / 2011$.

595 A SERES é composta por três Diretorias: Diretoria de Política Regulatória, Diretoria de Supervisão da Educação Superior, e Diretoria de Regulação da Educação Superior (Decreto nº 7.690/2012, Anexo I, artigos 27 a 29).
} 
relacionados à regulação e supervisão de instituições e cursos de educação superior; (g) manter e atualizar o catálogo dos cursos superiores de tecnologia; (h) propor as ações de concepção e atualização dos referenciais e das diretrizes curriculares dos cursos superiores de graduação; (i) propor referenciais de qualidade para a educação a distância, considerando as diretrizes curriculares da educação superior e as diversas tecnologias de informação e comunicação; (j) articular-se, em sua área de atuação, com instituições nacionais, estrangeiras e internacionais, mediante ações de cooperação institucional, técnica e financeira bilateral e multilateral; e (k) gerenciar, planejar, coordenar e executar as ações referentes à concessão dos certificados das entidades beneficentes de assistência social da área de educação, e decidir sobre a certificação. ${ }^{596}$

\subsubsection{Síntese do sistema de competências administrativas na regulação da educação superior}

Conforme apresentado, a regulação da educação superior é exercida por um sistema que inclui diversos órgãos do Ministério da Educação e uma autarquia a ele ligada - o INEP. Essa organização garante a participação do setor regulado na composição de seus órgãos, compreendendo, dessa maneira, elementos de regulação reflexiva. Por outro lado, a autoridade do poder estatal é mantida pela posição central no sistema do Ministro da Educação e do Secretário de Regulação e Supervisão da Educação Superior.

Tem-se, portanto, um sistema que pretende ser permeável à participação social, em especial dos atores envolvidos na atividade educacional superior, buscando, no entanto, resguardá-lo do perigo da captura dos agentes reguladores. A dispersão orgânica de atribuições e o menor grau de autonomia, dado o fato de ser desenvolvida principalmente no âmbito da administração direta, distingue esse sistema regulatório daquele utilizado pelas agências reguladoras.

O CNE, a exemplo das agências reguladoras, também possui competência normativa, ${ }^{597}$ mais restrita, no entanto, do que a dessas, tendo em vista o fato de que dependem da homologação do Ministro da Educação. Por essa razão, decorrente do fato de que integra a administração direta do Ministério da Educação, o CNE não tem o mesmo

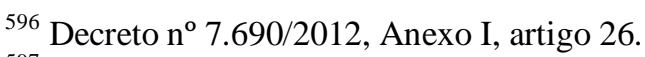

${ }^{597}$ Cf. Magno Federici Gomes, “Educação superior privada como serviço de utilidade pública”, p. 274.
} 
grau de autonomia das agências reguladoras, embora seus conselheiros também gozem da prerrogativa de terem mandato fixo.

Em caso de aprovação da criação do INSAES, o sistema regulatório da educação superior se aproximaria do regime das agências reguladoras, embora com menor grau de autonomia. ${ }^{598}$

\subsection{Avaliação da educação superior}

A fim de conferir concretude ao disposto no artigo 209 da Constituição, estabeleceu-se que a avaliação de qualidade da prestação da atividade educacional é o elemento fundamental da regulação desse setor, por meio de atos autorizativos. ${ }^{599}$ A LDB também prescreve que, em caso de deficiências identificadas pela avaliação, a instituição poderá contar com um prazo para saneamento de deficiências, após o qual haverá reavaliação, que poderá resultar, conforme o caso, em desativação de cursos e habilitações, em intervenção na instituição, em suspensão temporária de prerrogativas da autonomia, ou em descredenciamento. ${ }^{600}$

Dessa maneira, tem-se que, em linhas gerais, a estrutura legal estabelece a necessidade de avaliação periódica da qualidade de cursos e instituições para fundamentar a decisão regulatória consubstanciada na edição de atos autorizativos regulatórios periódicos. Além disso, caso sejam apontadas deficiências, há a previsão legal de prazo para saneamento, após o qual, caso infrutífero, enseja a abertura de procedimento administrativo visando à aplicação de penalidades.

A fim de estabelecer regulamentar essas disposições legais, o Decreto $\mathrm{n}^{\circ}$ 5.773/2006 estabelece que: (a) a avaliação constitui o referencial básico para os processos de regulação (em sentido estrito) e supervisão da educação superior, a fim de promover a melhoria de sua qualidade; (b) a regulação (em sentido estrito) realiza-se por meio de atos administrativos autorizativos do funcionamento de instituições de educação superior e de seus cursos; e (c) a supervisão será realizada a fim de zelar pela conformidade da oferta de educação superior no sistema federal de ensino com a legislação aplicável. ${ }^{601}$

\footnotetext{
${ }^{598}$ CF. 4.7.

${ }^{599}$ Cf. 2.2.1.

${ }^{600} \mathrm{LDB}$, art. $46, \S 1^{\circ}$.

${ }^{601}$ Decreto n $^{\mathrm{o}} 5.773 / 2006$, art. $1^{\mathrm{o}}, \S 1^{\mathrm{o}}$ a $3^{\mathrm{o}}$.
} 
A avaliação das instituições de educação superior, dos cursos de graduação e do desempenho acadêmico de seus estudantes será realizada no âmbito do SINAES, a fim de cumprir seus objetivos, nos termos da Lei $\mathrm{n}^{\circ} 10.861 / 2004$, compreendendo os seguintes processos de avaliação institucional: (a) avaliação interna das instituições de educação superior; (b) avaliação externa das instituições de educação superior; (c) avaliação dos cursos de graduação; e (d) avaliação do desempenho acadêmico dos estudantes de cursos de graduação. ${ }^{602}$

A avaliação, como referencial básico para a atividade regulatória de instituições e cursos, resultará na atribuição de conceitos, conforme uma escala de cinco níveis, presente, também, nos indicadores de qualidade, também estabelecidos na mesma escala. ${ }^{603}$ Os conceitos de avaliação e os indicadores de qualidade em níveis iguais ou superiores a 3 (três) indicam qualidade satisfatória.

A operacionalização do SINAES, de acordo com as diretrizes estabelecidas pela CONAES, é realizada pelo INEP em ciclos avaliativos, que compreendem a realização periódica de avaliação de instituições e cursos superiores, com referência nas avaliações trienais de desempenho de estudantes, as quais subsidiam, respectivamente, os atos de recredenciamento e de renovação de reconhecimento. ${ }^{604}$

\subsubsection{Elementos fundamentais para avaliação da educação superior}

Para a compreensão da organização da avaliação externa da educação superior, faz-se necessária a apresentação de alguns de seus elementos fundamentais: o Exame Nacional de Desempenho dos Estudantes (ENADE), o banco de avaliadores (BASIS), os instrumentos de avaliação, indicadores de qualidade e o núcleo docente estruturante.

\subsubsection{Exame Nacional de Desempenho dos Estudantes (ENADE)}

O Exame Nacional de Desempenho dos Estudantes (ENADE) é o instrumento para a realização da avaliação do desempenho dos estudantes em relação aos conteúdos programáticos previstos nas diretrizes curriculares do respectivo curso de graduação, suas

\footnotetext{
${ }^{602}$ Decreto n $^{\mathrm{o}} 5.773 / 2006$, art. 58, $\S 1^{\mathrm{o}}$, I a IV.

${ }^{603}$ Decreto n $^{\mathrm{o}} 5.773 / 2006$, art. 59, caput $\S 3^{\circ} \mathrm{c} / \mathrm{c}$ Portaria Normativa $\mathrm{n}^{\mathrm{o}} 40 / 2007$, art. 33-A, $\S \S 1^{\mathrm{o}}$ e $2^{\mathrm{o}}$.

${ }^{604}$ Portaria Normativa $\mathrm{n}^{\circ} 40 / 2007$, art. 33.
} 
habilidades para ajustamento às exigências decorrentes da evolução do conhecimento e suas competências para compreender temas exteriores ao âmbito específico de sua profissão, ligados à realidade brasileira e mundial e a outras áreas do conhecimento. ${ }^{605}$ Sua aplicação é periódica, sendo, por lei, trienal a periodicidade máxima de aplicação aos estudantes de cada curso, podendo ser utilizados procedimentos amostrais. ${ }^{606}$ Nos termos da Portaria Normativa $n^{\circ} 40 / 2007$, o ENADE é realizado todos os anos, aplicando-se trienalmente a cada curso, ${ }^{607}$ de modo a abranger, com a maior amplitude possível, as formações objeto das Diretrizes Curriculares Nacionais, da legislação de regulamentação do exercício profissional e do Catálogo de Cursos Superiores de Tecnologia. ${ }^{608}$

O ENADE é componente curricular obrigatório dos cursos de graduação, sendo responsabilidade do dirigente da instituição de educação superior a inscrição junto ao INEP de todos os alunos habilitados à participação, sob pena de aplicação de sanções. ${ }^{609} \mathrm{O}$ estudante que tenha participado do exame terá esse registro em seu histórico escolar, sendo que a regulamentação específica traz as hipóteses e procedimentos para justificativa de ausência. ${ }^{610}$ Caso a responsabilidade pela não realização do exame seja do estudante, esse deve requerer a regularização de sua situação, mediante a realização da prova geral de conhecimentos no ano seguinte. ${ }^{611}$

O ENADE é realizado pelo INEP, sob a orientação da CONAES, a partir de um banco de itens, elaborados por um corpo de especialistas, conforme orientação das comissões assessoras de área, para composição das provas. ${ }^{612} \mathrm{O}$ exame, aplicado aos estudantes ingressantes e concluintes de cada curso a ser avaliado, é composto de uma prova geral de conhecimentos e uma prova específica de cada área, esta aplicada apenas aos alunos concluintes, voltada a aferir as competências, habilidades e conteúdos agregados durante a formação. ${ }^{613}$

\footnotetext{
${ }^{605}$ Lei do SINAES, art. $5^{\circ}$, caput e $\S 1^{\circ}$, c/c Portaria Normativa n ${ }^{\circ}$ 40/2007, art. 33-D, caput.

${ }^{606}$ Lei do SINAES, art. $5^{\circ}, \S \S 2^{\circ}$ e $3^{\circ}$.

${ }^{607} \mathrm{O}$ calendário de aplicação do ENADE está estabelecido na Portaria Normativa n 40/2007, art. 33-E, $\$ \S 1^{\circ}$ e $2^{\circ}$.

${ }^{608}$ Portaria Normativa n ${ }^{\circ} 40 / 2007$, art. 33-E, caput.

${ }^{609}$ Lei do SINAES, art. $5^{\circ}, \S \S 5^{\circ}$ a $7^{\circ}$, art. 10, $\S 2^{\circ}$ c/c Portaria Normativa n ${ }^{\circ} 40 / 2007$, arts. 33-G, art. 33-I e art. 33-L.

${ }^{610}$ Portaria Normativa n ${ }^{\circ}$ 40/2007, art. 33-G.

${ }^{611}$ Portaria Normativa n ${ }^{\circ} 40 / 2007$, art. 33-L, $\$ 6^{\circ}$.

${ }^{612}$ Portaria Normativa $n^{\circ} 40 / 2007$, art. 33-D, $\$ \S 1^{\circ}$ e $2^{\circ}$.

${ }^{613}$ Portaria Normativa n ${ }^{\circ}$ 40/2007, art. 33-F.
} 
Como todos os conceitos de avaliação e indicadores de qualidade, a partir dos resultados do ENADE, é produzido um indicador de desempenho dos estudantes, expresso numa escala de cinco níveis, sendo que os estudantes em situação irregular não serão considerados para o cálculo do indicador baseado no ENADE. Ressalte-se que a informação dos resultados individuais dos estudantes será feita em boletim de acesso reservado. $^{614}$

\subsubsection{Banco de avaliadores (Basis)}

A avaliação de instituições e in loco de cursos e instituições é realizada por meio de comissões de avaliadores - docentes da educação superior, membros da comunidade universitária que, em nome de seus pares e por delegação do MEC, aferem a qualidade de instituições e cursos da educação superior. ${ }^{615}$ Os avaliadores devem integrar o Banco de Avaliadores do SINAES (Basis) - cadastro nacional, único e público de avaliadores da educação superior, selecionados e capacitados pelo INEP, administrado pela Diretoria de Avaliação da Educação Superior (DAES), que procederá às inclusões e exclusões pertinentes, ouvida a Comissão Técnica de Acompanhamento da Avaliação (CTAA), nos termos desta Portaria Normativa. ${ }^{616}$

Para se candidatar ao Basis, o docente, que precisa preencher alguns requisitos, ${ }^{617}$ deve inscrever-se voluntariamente em módulo próprio do sistema e-MEC. Os candidatos selecionados são convocados para a realização de capacitação presencial pelo INEP, voltada à aplicação dos instrumentos de avaliação. Ao final do processo de capacitação, o candidato, se convocado pelo INEP, deverá firmar um termo de compromisso, após o que, o docente será admitido como avaliador e inserido no Basis, por ato da DAES, homologado pela CTAA e devidamente publicado. ${ }^{618}$

\footnotetext{
${ }^{614}$ Portaria Normativa n ${ }^{\circ}$ 40/2007, art. 33-B, caput, III e art. 33-L.

${ }^{615}$ Portaria Normativa $\mathrm{n}^{\circ} 40 / 2007$, art. 17-A, caput.

${ }^{616}$ Portaria Normativa $n^{\circ} 40 / 2007$, art. 17-B.

${ }^{617}$ Portaria Normativa n ${ }^{\circ}$ 40/2007, art. 17-C:

"Art. 17-C São requisitos para candidatar-se ao Basis:

I - ser docente inscrito no Cadastro Nacional de Docentes, instituído pela Portaria $\mathrm{n}^{\circ} 327$, de $1^{\circ}$ de fevereiro de 2005, portador de titulação universitária não inferior a mestre;

II - comprovar exercício da docência, em nível superior, de pelo menos 3 (três) anos, em instituição e curso regulares conforme o Cadastro e-MEC;

III - possuir produção científica nos últimos 3 (três) anos, registrada no currículo Lattes;

IV - ter disponibilidade para participar de pelo menos três avaliações anuais; e

V - não ter pendências junto às autoridades tributárias e previdenciárias."

${ }^{618}$ Portaria Normativa n ${ }^{\circ} 40 / 2007$, art. 17-D.
} 
Uma vez que as avaliações in loco se destinam ao conhecimento e registro das condições concretas em que se desenvolvem as atividades educacionais, os avaliadores não têm delegação do INEP ou de qualquer órgão do MEC para aconselhar ou orientar a instituição em relação à atividade educacional. ${ }^{619}$ Por essa razão, os avaliadores devem se abster de desenvolver tais atividades, bem como de promover atividades de consultoria e assessoria educacional, eventos, cursos e palestras, bem como produzir materiais de orientação sobre os procedimentos de avaliação do INEP. ${ }^{620}$ Além dessas, são vedadas aos avaliadores outras condutas, ${ }^{621}$ e lhes são exigidas uma conduta ética relativa a deveres funcionais. ${ }^{622} \mathrm{O}$ avaliador será excluído do Basis, por decisão do CTAA, nas hipóteses previstas no artigo $17-\mathrm{G}$ da Portaria Normativa $n^{\circ} 40 / 2007 .{ }^{623}$ Durante a realização de sua atividade, o avaliador é considerado um agente público, na categoria de particular em colaboração com o Poder Público, que inclui "pessoas físicas que prestam serviços ao Estado, sem vínculo empregatício, com ou sem remuneração". ${ }^{624}$

A designação de avaliadores para a composição de cada comissão de avaliação é realizada por sorteio eletrônico, assegurando a observância de determinados parâmetros de mérito, ${ }^{625}$ a aplicação de critérios eliminatórios operacionais aos avaliadores, ${ }^{626}$ bem como a aplicação de critérios classificatórios entre os avaliadores. ${ }^{627}$ A cada designação, o avaliador deverá firmar termo de aceitação da designação, no prazo de 48 (quarenta e oito) horas. ${ }^{628}$ Com a participação em uma avaliação in loco, o avaliador faz jus ao recebimento do auxílio de avaliação educacional, criado pela Lei no 11.507 , de 20 de julho de 2007.

\footnotetext{
${ }^{619}$ Portaria Normativa n ${ }^{\circ} 40 / 2007$, art. 17-A, parágrafo único.

${ }^{620}$ Portaria Normativa $\mathrm{n}^{\circ} 40 / 2007$, art. $17-\mathrm{F}$, II e III.

${ }^{621}$ Portaria Normativa $n^{\circ} 40 / 2007$, art. 17-F.

${ }^{622}$ Portaria Normativa $\mathrm{n}^{\circ} 40 / 2007$, art. 17-E.

${ }^{623}$ Portaria Normativa n ${ }^{\circ} 40 / 2007$, art. 17-G:
}

“Art. 17-G O avaliador será excluído do Basis, por decisão da CTAA, nas seguintes hipóteses: I - voluntariamente, a pedido do avaliador;

II - em casos de inadequação reiterada dos relatórios às diretrizes de avaliação aplicáveis;

III - para conformidade com as exigências pertinentes à atividade de avaliação, observadas as diretrizes desta Portaria Normativa; ou

IV - pelo descumprimento de deveres, ou do Termo de Compromisso, ou inobservância de vedações referidas no art. 17-F desta Portaria Normativa, assegurados defesa e contraditório.

$\S 1^{\circ}$ Caberá à DAES processar as denúncias ou manifestações circunstanciadas que cheguem ao seu conhecimento a respeito dos integrantes do Basis.

$\S 2^{\circ}$ Na hipótese do inciso II, a CTAA poderá optar pela recapacitação do avaliador, uma única vez.

$\S 3^{\circ}$ A exclusão do avaliador com base no inciso IV perdurará pelo prazo mínimo de 3 (três) anos e impedirá sua participação na Comissão Própria de Avaliação (CPA) de instituição pelo mesmo período.”

${ }^{624}$ Maria Sylvia Zanella Di Pietro, Direito administrativo, p. 588.

${ }^{625}$ Portaria Normativa $\mathrm{n}^{\circ}$ 40/2007, art. 17-H, I.

${ }^{626}$ Portaria Normativa n ${ }^{\circ} 40 / 2007$, art. 17-H, II.

${ }^{627}$ Portaria Normativa $\mathrm{n}^{\circ}$ 40/2007, art. 17-H, III.

${ }^{628}$ Portaria Normativa no $40 / 2007$, art. 17-I. 


\subsubsection{Instrumentos de avaliação}

A fim de padronizar os critérios de avaliação, as atividades exercidas pelas comissões de avaliação são orientadas por indicadores de avaliação, quando disponíveis, e por instrumentos de avaliação. ${ }^{629}$ Os instrumentos de avaliação constituem o referencial para a realização da avaliação in loco, detalhado do modo mais objetivo possível, a partir dos quais os avaliadores atribuem conceitos para cada uma das dimensões avaliadas.

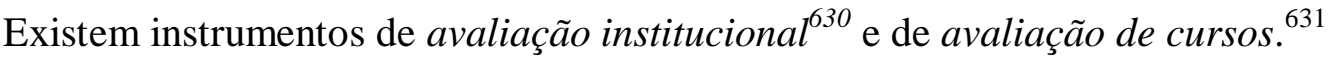

Os instrumentos de avaliação institucional, para credenciamento e recredenciamento de instituições, são elaborados pelo INEP, a partir de diretrizes estabelecidas pela CONAES e pela SERES - estas com aprovação do CNE - e submetidas à aprovação do CNE, após o que devem ser homologados pelo Ministro da Educação. ${ }^{632}$

O instrumento de avaliação para credenciamento de instituições compreende a análise de três dimensões: a organização institucional, o corpo social e as instalações físicas. O instrumento de avaliação para recredenciamento de instituições, uma vez que tem por objeto uma instituição em pleno funcionamento, apresenta maior grau de detalhamento, compreendendo dez dimensões: (a) a Missão e o Plano de Desenvolvimento Institucional (PDI); (b) a política para o ensino (graduação e pós-graduação), a pesquisa, a extensão e as respectivas normas de operacionalização, incluídos os procedimentos para estímulo à produção acadêmica, para as bolsas de pesquisa, de monitoria e demais modalidades; (c) a responsabilidade social da instituição, considerada especialmente no que se refere à sua contribuição em relação à inclusão social, ao desenvolvimento econômico e social, à defesa do meio ambiente, da memória cultural, da produção artística e do patrimônio cultural; (d) a comunicação com a sociedade; (e) as políticas de pessoal, de carreiras do corpo docente e corpo técnico-administrativo, seu aperfeiçoamento, seu desenvolvimento profissional e suas condições de trabalho; (f) a organização e gestão da instituição, especialmente o funcionamento e representatividade dos colegiados, sua independência e autonomia na relação com a mantenedora, e a participação dos segmentos da comunidade universitária nos processos decisórios; (g) a infraestrutura física, especialmente a de ensino e de pesquisa, biblioteca, recursos de informação e

${ }^{629}$ Portaria Normativa n ${ }^{\circ} 40 / 2007$, art. 17-J.

630 Disponíveis em: http://portal.inep.gov.br/superior-avaliacao_institucional-instrumentos, acesso em 17.01.2013.

${ }^{631}$ Disponíveis em: http://portal.inep.gov.br/superior-condicoesdeensino-manuais, acesso em 17.01.2013. ${ }^{632}$ Cf. 5.4. 
comunicação; (h) o planejamento e a avaliação, especialmente em relação aos processos, resultados e eficácia da autoavaliação institucional; (i) as políticas de atendimento aos discentes; e (j) a sustentabilidade financeira, tendo em vista o significado social da continuidade dos compromissos na oferta da educação superior.

Os instrumentos de avaliação de curso, para autorização, reconhecimento e renovação de reconhecimento, são elaborados pelo INEP, a partir de diretrizes estabelecidas pela CONAES e pela SERES, necessitando, também de homologação do Ministro de Estado. ${ }^{633}$

Os instrumentos de avaliação de curso são direcionados para a avaliação de três dimensões: a organização didático-pedagógica, o corpo docente e as instalações físicas. Há instrumentos de avaliação específicos para alguns cursos, como Direito, Medicina e Pedagogia, e outros genericamente destinados a outros bacharelados e licenciaturas. Há também instrumentos específicos para cursos superiores tecnológicos.

Os instrumentos de avaliação devem ser parâmetros periodicamente ajustados para adaptá-los à realidade brasileira, por meio de um sistema que permite a participação dos setores envolvidos. Para Vladmir Oliveira da Silveira e Irene Patrícia Nohara, "não são recomendáveis as "desregulações abruptas", que promovem a instabilidade no cenário da supervisão educacional." 634

\subsubsection{Indicadores de qualidade}

Os indicadores de qualidade são expressões objetivas de qualidade, obtidos por meio de recursos estatísticos, da comparação de desempenho, que variam na escala de 1 (um) a 5 (cinco), podendo ser preliminares ou definitivos, e relativos à instituições ou cursos. $^{635}$ Há no sistema regulatório da educação superior brasileiro os seguintes indicadores de qualidade: (a) Conceito Preliminar de Curso (CPC); (b) Conceito de Curso (CC); (c) Índice Geral de Cursos Avaliados da Instituição (IGC); e (d) Conceito de Instituição (CI).

\footnotetext{
${ }^{633}$ Cf. 5.4.

${ }^{634}$ Vladmir Oliveira da Silveira / Irene Patrícia Nohara, "Supervisão do ensino superior de direito no contexto federativo e complexidades do controle da pós-graduação stricto sensu”, p. 290.

635 Para o detalhamento estatístico da produção desses indicadores, vide Fernandes, Reynaldo / Pazello, Elaine Toldo / Leitão, Thiago Miguel Sabino de Pereira / Moriconi, Gabriela Miranda. Avaliação de cursos na educação superior: a função e a mecânica do Conceito Preliminar de Curso. Brasília: INEP, 2009.
} 
A participação social no sistema regulatório da educação superior é fundamental na produção e na avaliação dos indicadores de avaliação, que precisam ser calibrados com frequência, por meio, por exemplo, da alteração do peso de seus componentes, para melhor atender a seus objetivos.

Em relação a cursos, o Conceito Preliminar de Curso (CPC), que fora instituído pela Portaria Normativa 4/2008, ${ }^{636}$ é o indicador de qualidade de cursos superiores calculado pelo INEP, segundo metodologia própria, aprovada pela CONAES, no ano seguinte ao da realização do ENADE de cada área, com base na avaliação de desempenho de estudantes, corpo docente, infraestrutura, recursos didático-pedagógicos e demais insumos, conforme orientação técnica aprovada pela CONAES. ${ }^{637}$ Trata-se de um indicador prévio da situação dos cursos de graduação. Cursos que obtiverem CPC 1 (um) e 2 (dois) serão automaticamente incluídos no cronograma de visitas dos avaliadores do INEP para verificação in loco das condições de ensino. Cursos com conceito igual ou superior a 3 (três) podem optar por não receber a visita dos avaliadores e, assim, transformar o CPC em Conceito de Curso (CC). O CPC de cada grupo de cursos é divulgado a cada ciclo avaliativo, portanto a cada 3 (três) anos, junto com os resultados do ENADE.

O Conceito de Curso (CC) é um conceito de avaliação constituído pela confirmação do CPC de cursos com conceito igual ou superior a 3 (três) que não tenham optado pela visita in loco, ou constituído após verificação in loco realizada por Comissão de Avaliação do INEP, consideradas, em especial, as condições relativas ao perfil do corpo docente, à organização didático-pedagógica e às instalações físicas, ${ }^{638}$ podendo confirmar ou modificar o CPC.

No que se refere a instituições, o Índice Geral de Cursos Avaliados da Instituição (IGC), que fora instituído pela Portaria Normativa 12/2008, ${ }^{639}$ é o indicador de qualidade de instituições de educação superior calculado anualmente pelo INEP, segundo metodologia própria, aprovada pela CONAES, independentemente do número de cursos avaliados, considerando: (a) a média dos últimos CPCs disponíveis dos cursos avaliados da

\footnotetext{
${ }^{636}$ Revogado pela Portaria Normativa $n^{\circ} 40 / 2007$, art. 70, III, com redação dada pela Portaria Normativa 23/2010 (que consolidou suas disposições), com a manutenção dos efeitos já produzidos.

${ }^{637}$ Portaria Normativa $n^{\circ} 40 / 2007$, art. 33-B, caput e $\S 1^{\circ}$.

${ }^{638}$ Portaria Normativa $\mathrm{n}^{\circ}$ 40/2007, art. 33-C, I.

639 Revogado pela Portaria Normativa no 40/2007, art. 70, III, com redação dada pela Portaria Normativa 23/2010 (que consolidou suas disposições), com a manutenção dos efeitos já produzidos.
} 
instituição no ano do cálculo e nos dois anteriores, ponderada pelo número de matrículas em cada um dos cursos computados; (b) a média dos conceitos de avaliação dos programas de pós-graduação stricto sensu atribuídos pela CAPES na última avaliação trienal disponível, convertida para escala compatível e ponderada pelo número de matrículas em cada um dos programas de pós graduação correspondentes; (c) a distribuição dos estudantes entre os diferentes níveis de ensino, graduação ou pós-graduação stricto sensu. $^{640}$

O Conceito de Instituição (CI) é um conceito de avaliação, após verificação in loco realizada por Comissão de Avaliação do INEP, consideradas as dimensões analisadas na avaliação institucional externa. ${ }^{641}$

Após a realização da avaliação in loco pela comissão de avaliação, deve ocorrer a divulgação de seu resultado, que atribui a instituições ou cursos, respectivamente, um conceito de curso (CC) ou conceito de instituição (CI). O respectivo conceito e o relatório de avaliação devem ser disponibilizados para a exibição no Cadastro e-MEC. Caso ocorra revisão do conceito, por decisão da CTAA, após provimento de recurso, o CC ou CI revisto deve ser lançado pela no Cadastro e-MEC.

No caso de dispensa da avaliação in loco, com base em CPC ou IGC satisfatórios, o Cadastro e-MEC exibe a menção "dispensado" nos campos correspondentes ao $\mathrm{CC}$ ou $\mathrm{CI}$, respectivamente. ${ }^{642}$

O CPC e o IGC são calculados por sistema informatizado do INEP, considerando os insumos coletados nas bases de dados oficiais. Em caso de questionamento a respeito da exatidão dos indicadores, pode ser requerida a sua retificação, em campo próprio do sistema e-MEC, no prazo de até 10 (dez) dias da ciência. Uma vez que não haja pedido de retificação, ou após a análise do pedido de retificação, o INEP publicará os indicadores no Cadastro e-MEC e no Diário Oficial da União. ${ }^{643}$

\footnotetext{
${ }^{640}$ Portaria Normativa $n^{\circ} 40 / 2007$, art. 33-B, caput e $\$ \S 2^{\circ}$ e $7^{\circ}$.

${ }^{641}$ Portaria Normativa $n^{\circ} 40 / 2007$, art. 33-C, II.

${ }^{642}$ Portaria Normativa $n^{\circ} 40 / 2007$, art. $34, \S \S 5^{\circ}$ a $7^{\circ}$.

${ }^{643}$ Portaria Normativa $n^{\circ} 40 / 2007$, art. $34, \S \S 1^{\circ}$ a $4^{\circ}$.
} 


\subsubsection{Núcleo docente estruturante}

O núcleo docente estruturante é um importante instituto da regulação da educação superior que conta atualmente com a seguinte conceituação;

"Núcleo docente estruturante - conjunto de professores da instituição responsável pela formulação do projeto pedagógico do curso, sua implementação e desenvolvimento, composto por professores com titulação em nível de pós-graduação stricto sensu, contratados em regime de trabalho que assegure preferencialmente dedicação plena ao curso, e com experiência docente. ${ }^{\circ 44}$

Trata-se de um fundamental fator indicativo da qualidade de um curso, criado, inicialmente, por meio da Portaria Normativa/MEC $n^{\circ}$ 147, de 2 de fevereiro de 2007, especificamente para os cursos de Direito e de Medicina, com o intuito de qualificar o envolvimento docente no processo de concepção e consolidação do curso, com o estabelecimento de uma determinada proporção de professores do curso com maior nível de dedicação ao curso e titulação acadêmica, com a finalidade de colaborar para direcionar a efetivação do projeto pedagógico de curso (PPC). Nesse sentido, o NDE deve ser a "alma" de um curso superior, responsável pelo planejamento, implantação, revisão e aperfeiçoamento constante do PPC, conforme aponta Frederico Normanha Ribeiro de Almeida:

"Formado por parte do corpo docente com maior dedicação ao curso e à instituição de ensino, e com maior experiência e titulação acadêmica, o NDE deve se constituir como espaço de produção de conhecimento e de reflexão sobre as práticas pedagógicas adotadas no curso, trazendo para essa arena de discussão as experiências passadas e as adquiridas no cotidiano da sala de aula por aqueles professores. É por meio da efetividade de um NDE dedicado e atuante que o PPC é capaz de obter aderência à realidade do ensino-aprendizagem no cotidiano do curso[...]" ${ }^{645}$

Com base nessa experiência, a Comissão Nacional de Avaliação da Educação Superior (CONAES) aprovou o Parecer $\mathrm{n}^{\circ}$ 4, de 17 de junho de 2010, que ressaltou a importância de um grupo de professores fundamental para a constituição da identidade de um curso:

"A idéia surge da constatação de que um bom curso de graduação tem alguns membros do seu corpo docente que ajudam a construir a identidade do mesmo. Não se trata de personificar um

${ }^{644}$ Portaria Normativa/MEC n ${ }^{\circ}$ 40/2007, Anexo, item 9.4.

${ }^{645}$ Frederico Normanha Ribeiro de Almeida, "Avaliação de qualidade, profissionalização da docência e ensino jurídico", in Paulo Roberto Moglia Thompson Flores (org.), Desafios rumo à educação jurídica de excelência, Brasília: OAB, Conselho Federal, Comissão Nacional de Ensino Jurídico, 2011, p. 133. 
curso, mas de reconhecer que educação se faz com pessoas e que há, em todo grupo social, um processo de liderança que está além dos cargos instituídos.

\section{$[\ldots]$}

Com isso se pode evitar que os PPCs sejam uma peça meramente documental. Entende-se, então, que todo curso que tem qualidade possui (ainda que informalmente) um grupo de professores que, poder-se-ia dizer, é a alma do curso.”

Fundamentada nesse parecer, foi editada a Resolução/CONAES n ${ }^{\circ}$ 01, de 17 de julho de 2010, que instituiu a obrigatoriedade da instituição de um NDE em cada curso superior, a com a função de acompanhamento atuante "no processo de concepção, consolidação e contínua atualização do projeto pedagógico do curso". ${ }^{646}$ O NDE deve ser composto por professores do curso que "exerçam liderança acadêmica no âmbito do mesmo, percebida na produção de conhecimentos na área, no desenvolvimento do ensino, e em outras dimensões entendidas como importantes pela instituição". ${ }^{647}$

Segundo a Resolução/CONAES no 1/2010, são atribuições do NDE: (a) contribuir para a consolidação do perfil profissional do egresso do curso; (b) zelar pela integração curricular interdisciplinar entre as diferentes atividades de ensino constantes no currículo; (c) indicar formas de incentivo ao desenvolvimento de linhas de pesquisa e extensão, oriundas de necessidades da graduação, de exigências do mercado de trabalho e afinadas com as políticas públicas relativas à área de conhecimento do curso; e (d) zelar pelo cumprimento das Diretrizes Curriculares Nacionais para os Cursos de Graduação. ${ }^{648}$

Em termos quantitativos e qualitativos, a Resolução/CONAES n ${ }^{\circ}$ 1/2010 estabelece que o NDE deve (a) ser constituído por um mínimo de cinco professores pertencentes ao corpo docente do curso; (b) ter pelo menos $60 \%$ de seus membros com titulação acadêmica obtida em programas de pós-graduação stricto sensu; (c) todos os membros em regime de trabalho de tempo parcial ou integral, sendo pelo menos $20 \%$ em tempo integral; e (d) assegurar estratégia de renovação parcial dos integrantes do NDE de modo a assegurar continuidade no processo de acompanhamento do curso. ${ }^{649}$ Essas exigências foram incorporadas aos instrumentos de avaliação de cursos. ${ }^{650}$

\footnotetext{
${ }^{646}$ Resolução/CONAES no 01/2010, artigo $1^{\circ}$, caput.

${ }^{647}$ Resolução/CONAES n ${ }^{\circ} 01 / 2010$, artigo $1^{\circ}$, parágrafo único.

${ }^{648}$ Resolução/CONAES no 01/2010, artigo $2^{\circ}$.

${ }^{649}$ Resolução/CONAES no ${ }^{\circ} 01 / 2010$, artigo $3^{\circ}$.

${ }^{650}$ Cf. 5.5.1.3.
} 
À vista do quadro evolutivo apresentado, o núcleo docente estruturante consolidou-se como um instituto fundamental da atividade de avaliação, regulação e supervisão da educação superior, à medida que estabelece a relação entre duas das três dimensões fundamentais da avaliação de um curso superior: a organização didáticopedagógica e o corpo docente. O NDE pode ser compreendido como uma importante parte do corpo docente responsável por tornar dinâmico o projeto pedagógico do curso, que, analisado isoladamente, tem caráter estático. ${ }^{651}$

No entanto, o estabelecimento do número de cinco membros no NDE, por curso, com o intuito de evitar um "tamanho desmesurado, que inviabilizaria suas ações", pode descaracterizar a atuação do NDE em cursos com um elevado número de alunos, divididos em diversas unidades de ensino no mesmo município. Em tal situação, formalmente, há apenas um curso, mas, de fato, vários. Por essa razão, em evento organizado A fim de evitar essa descaracterização, sem aumentar desmesuradamente o NDE, em evento organizado pela Ordem dos Advogados do Brasil, ${ }^{652}$ propus que a exigência quantitativa de docentes não se desse por curso, mas por unidade educacional, nos seguintes termos:

"As Instituições de Educação Superior, por meio dos seus colegiados superiores, devem definir as atribuições e os critérios de constituição do NDE, atendidos, no mínimo, os seguintes:

I - ser constituído um núcleo docente estruturante por unidade educacional, conforme definição constante do item 8.2 do Anexo à Portaria Normativa/MEC nº 40/2007, alterada pela Portaria Normativa/MEC n 23/2010;

II - ser constituído por um mínimo de $10 \%$ do corpo docente do curso em cada unidade educacional, contando com o número mínimo de 5 professores pertencentes ao corpo docente do curso, sendo que cada professor poderá integrar apenas um NDE;

III - ter pelo menos $60 \%$ de seus membros com titulação acadêmica obtida em programas de pós graduação stricto sensu;

IV - ter todos os membros em regime de trabalho de tempo parcial ou integral, sendo pelo menos $20 \%$ em tempo integral;

${ }^{651}$ Cf. Claudio Mendonça Braga, "O núcleo docente estruturante como elemento indicador da qualidade dos cursos jurídicos", in Necessidades sociais e expectativas da educação jurídica de qualidade, Brasília: OAB, 2013, no prelo.

${ }^{652}$ II Seminário de Educação Jurídica, promovido pela Comissão Nacional de Ensino Jurídico do Conselho Federal da Ordem dos Advogados do Brasil, de 31 de março a $1^{\circ}$ de abril de 2011, na cidade do Rio de Janeiro/RJ. 
V - assegurar estratégia de renovação parcial dos integrantes do NDE de modo a assegurar continuidade no processo de acompanhamento do curso." ${ }^{.653}$

Nessa linha da proposta, entendo que esse instituto - que vem se demonstrando fundamental para a consolidação de um parâmetro efetivo de avaliação de qualidade dos cursos superiores - poderia ser aprimorado.

\subsubsection{Análise documental}

O procedimento regulatório da educação superior se inicia pela provocação do interessado, que deverá apresentar eletronicamente uma série de documentos, de acordo com a natureza do ato autorizativo pretendido. Em linhas gerais, os documentos exigidos podem se referir: (a) à habilitação jurídica da mantenedora; (b) à regularidade fiscal da mantenedora; (c) à qualificação econômico-financeira da mantenedora; (d) à estrutura jurídica e administrativa da instituição mantida; (e) ao desenvolvimento da atividade educacional pela instituição mantida; (f) à comprovação do pagamento da taxa de avaliação; e (g) à comprovação da disponibilidade do imóvel no qual serão desenvolvidas atividades educacionais.

A análise documental configura-se como uma fase administrativa, anterior à avaliação, de verificação formal de pré-requisitos exigidos para o desenvolvimento do processo regulatório.

\subsubsection{Análise documental nos processos de credenciamento e recredenciamento}

Em relação aos processos de credenciamento e recredenciamento, o pedido deve ser instruído com os documentos relacionados nos arts. 15 e 16 do Decreto $\mathrm{n}^{\circ}$ 5.773/2006. Quanto à habilitação jurídica da mantenedora, devem ser apresentados: (a) atos constitutivos, devidamente registrados no órgão competente, que atestem sua existência e capacidade jurídica, na forma da legislação civil; e (b) comprovante de inscrição no Cadastro Nacional de Pessoas Jurídicas do Ministério da Fazenda CNPJ/MF. Em relação à regularidade fiscal da mantenedora, devem ser juntados: (a) comprovante de inscrição nos cadastros de contribuintes estadual e municipal, quando for ${ }^{653}$ Claudio Mendonça Braga, "O Núcleo docente estruturante como elemento indicador da qualidade dos
cursos jurídicos". 
o caso; (b) certidões de regularidade fiscal perante as Fazendas Federal, Estadual e Municipal; e (c) certidões de regularidade relativa à Seguridade Social e ao Fundo de Garantia do Tempo de Serviço - FGTS. Em relação à qualificação econômico-financeira da mantenedora, deve-se apresentar: (a) demonstração de patrimônio para manter a instituição; (b) demonstração de aplicação dos seus excedentes financeiros para os fins da instituição mantida; não remuneração ou concessão de vantagens ou benefícios a seus instituidores, dirigentes, sócios, conselheiros, ou equivalentes e, em caso de encerramento de suas atividades, destinação de seu patrimônio a outra instituição congênere ou ao Poder Público, promovendo, se necessário, a alteração estatutária correspondente (apenas para as entidades sem fins lucrativos); e (c) apresentação de demonstrações financeiras atestadas por profissionais competentes (para as entidades com fins lucrativos).

Em relação à instituição de educação superior, para os pedidos de credenciamento ou recredenciamento de instituição, deve-se apresentar: (a) o comprovante de recolhimento da taxa de avaliação in loco; e (b) os documentos relativos à estrutura jurídica e administrativa da instituição mantida - regimento ou o estatuto da instituição (ou suas alterações, no caso de recredenciamento), bem como a identificação dos integrantes do corpo dirigente, destacando a experiência acadêmica e administrativa de cada um.

Por último, cabe ressaltar que os pedidos de credenciamento devem ser instruídos com um importante documento relativo ao desenvolvimento educacional da instituição: o plano de desenvolvimento institucional (PDI). Os pedidos de recredenciamento devem ser instruídos com a atualização do PDI. O plano de desenvolvimento educacional, cujos elementos necessários constam do artigo 16 do Decreto $\mathrm{n}^{\mathrm{o}} 5.773 / 2006$, é o documento que visa a fundamentar, em várias dimensões, o desenrolar da atividade da instituição. Em apertada síntese, o PDI deve conter a missão, os objetivos e o projeto pedagógico da instituição, o cronograma de implantação de suas atividades, a organização didático-pedagógica da instituição, em seus detalhes, o perfil do corpo docente, a organização administrativa da instituição, a infraestrutura física e instalações acadêmicas, a previsão de oferta de cursos, em todas as modalidades, bem como o demonstrativo de capacidade e sustentabilidade financeiras.

Cabe ressaltar que a análise dos documentos mencionados, exigidos também para processos de transferência de mantença, no que se refere a aspectos financeiros e fiscais, não compreendem atividade típica da estrutura do Ministério da Educação, que 
tende a desenvolver uma atuação meramente cartorial nesse assunto. Trata-se, evidentemente, de aferição importante, tendo em vista os reflexos econômicos envolvidos. Por essa razão, seria importante o estabelecimento de algum tipo de ajuste com o Ministério da Fazenda e seus órgãos, bem como com o Sistema Brasileiro de Defesa da Concorrência - SBDC, para operações de concentração econômica em relações societárias promovidas por mantenedoras de instituições de ensino superior.

Nesse sentido, recentemente foi anunciado o estabelecimento de uma parceria entre o MEC e o Conselho de Administração de Defesa Econômico (CADE), a fim de aperfeiçoar os mecanismos de controle nos processos de compra e venda de instituições de educação superior. $^{654}$

\subsubsection{Análise documental nos processos de autorização, reconhecimento e renovação de reconhecimento}

No que se refere aos processos de autorização, o pedido deve ser instruído com os documentos relacionados no artigo 30 do Decreto $\mathrm{n}^{\circ}$ 5.773/2006: (a) comprovante de recolhimento da taxa de avaliação in loco; (b) projeto pedagógico do curso, informando número de alunos, turnos, programa do curso e demais elementos acadêmicos pertinentes; (c) relação de docentes, acompanhada de termo de compromisso firmado com a instituição, informando-se a respectiva titulação, carga horária e regime de trabalho; e (d) comprovante de disponibilidade do imóvel.

Os pedidos de reconhecimento devem ser protocolados no período entre metade do prazo previsto para a integralização de sua carga horária e setenta e cinco por cento desse prazo. ${ }^{655}$ Os pedidos de renovação de reconhecimento devem ser protocolados ao final de cada ciclo avaliativo do SINAES. ${ }^{656}$ Para ambos os casos, os pedidos devem ser instruídos com os seguintes documentos: (a) comprovante de recolhimento da taxa de avaliação in loco; (b) projeto pedagógico do curso, incluindo número de alunos, turnos e

\footnotetext{
654 Nesse sentido, vide MEC e Cade unem-se na regulação universitária. Disponível em http://www.senado.gov.br/noticias/opiniaopublica/inc/senamidia/notSenamidia.asp?ud=20121130\&datNotici $\mathrm{a}=20121130 \& \operatorname{codNoticia}=782472 \&$ nomeOrgao $=\&$ nomeJornal $=$ Valor + Econ $\%$ C3\%B4mico\&codOrgao $=272$ 9\&tipPagina=1, acesso em 12.12.2012.

${ }^{655}$ Decreto $^{\circ} 5.773 / 2006$, art. 35 , caput.

${ }^{656}$ Decreto no $^{\circ}$.773/2006, art. 41, caput.
} 
demais elementos acadêmicos pertinentes; (c) relação de docentes, constante do cadastro nacional de docentes; e (d) comprovante de disponibilidade do imóvel. ${ }^{657}$

\subsubsection{Decisão e recurso na fase de análise documental}

A Secretaria de Regulação e Supervisão da Educação Superior dará impulso ao processo, procedendo à análise dos documentos apresentados, sob os aspectos da regularidade formal e do mérito do pedido, podendo determinar a realização de diligências necessárias à completa instrução do processo, visando a subsidiar a deliberação final. ${ }^{658} \mathrm{~A}$ diligência deverá ser atendida no prazo de 30 (trinta) dias, sob pena de arquivamento do processo. $^{659}$

Concluída a análise dos documentos, o processo segue para o Diretor de Regulação da Educação Superior, ${ }^{660}$ para apreciação da instrução, determinação da correção das irregularidades sanáveis, se for o caso, ou o arquivamento do processo, quando a insuficiência de elementos de instrução impedir o seu prosseguimento. ${ }^{661}$

Ressalte-se que não é possível a realização de alterações do pedido após o protocolo. Por essa razão, em caso de alteração relevante de qualquer dos elementos de instrução do pedido de ato autorizativo, o requerente deverá solicitar seu arquivamento e protocolar novo pedido, devidamente alterado. $\mathrm{O}$ arquivamento do pedido, nesta hipótese, gera em favor do requerente, crédito do valor da taxa de avaliação recolhida correspondente ao pedido arquivado, salvo se efetuado após a fase de avaliação, hipótese na qual não haverá restituição do valor da taxa. ${ }^{662}$

No caso de decisão de arquivamento por parte do Diretor de Regulação da Educação Superior, caberá recurso ao Secretário de Regulação e Supervisão da Educação Superior, no prazo de 10 (dez) dias, sendo que a decisão proferida pelo Secretário é irrecorrível. ${ }^{663}$

\footnotetext{
${ }^{657}$ Decreto $^{\mathrm{o}} 5.773 / 2006$, art. $35,1^{\circ}$ e art. $41, \S 1^{\mathrm{o}}$.

${ }^{658}$ Decreto no $^{\circ} 5.773 / 2006$, art. 17, caput e $\$ \S 1^{\circ}$ e $3^{\circ}$, Decreto $n^{\circ} 5.773 / 2006$, art. 31, caput e $\S 1^{\circ}$.

${ }^{659}$ Portaria Normativa $\mathrm{n}^{\circ} 40 / 2007$, art. $10, \S 3^{\circ}$.

${ }^{660}$ Decreto 7690/2012, Anexo I, art. 2 , II, “e”, 3 c/c Portaria Normativa n 40/2007, art. 66.

${ }^{661}$ Portaria Normativa ${ }^{\circ} 40 / 2007$, art. 11, caput.

${ }^{662}$ Portaria Normativa n ${ }^{\circ} 40 / 2007$, art. $11, \S \S 1^{\circ}$ a $4^{\circ}$.

${ }^{663}$ Portaria Normativa $\mathrm{n}^{\circ}$ 40/2007, art. 12.
} 
Após análise documental, a Secretaria de Regulação e Supervisão da Educação Superior, se for o caso, encaminhará o processo ao INEP para a realização de avaliação in loco. ${ }^{664}$ No caso de ocorrência de múltiplos endereços, a avaliação in loco poderá ser feita por amostragem, a juízo da Diretoria de Regulação da Educação Superior, a quem competirá assinalar os locais a serem visitados pelo INEP. ${ }^{665}$

\subsubsection{Dispensa da avaliação in loco, visitas por amostragem e possibilidade de prorrogação da validade de atos autorizativos}

Existe a possibilidade da dispensa da avaliação in loco com base nos indicadores de qualidade. Nos pedidos de autorização, isso pode ocorrer, por decisão do Diretoria de Regulação da Educação Superior, após a análise documental, mediante despacho fundamentado, condicionada ao Conceito Institucional (CI) e Indice Geral de Cursos Avaliados da Instituição (IGC) da instituição mais recentes iguais ou superiores a 3 (três), cumulativamente. ${ }^{666}$ Essa possibilidade não se aplica aos pedidos de autorização de cursos de graduação em direito, medicina, odontologia e psicologia, inclusive em universidades e centros universitários. ${ }^{667}$

É possível, ainda, no caso de CI ou IGC inferiores a 3 (três), ${ }^{668}$ com base na ponderação motivada dos elementos de instrução do processo e da situação da instituição, o indeferimento do pedido de autorização independentemente da visita de avaliação in loco. Um dos fundamentos expressamente suficiente para esse indeferimento é a reduzida proporção - correspondente a menos de 50\% (cinquenta por cento) de cursos reconhecidos em relação aos cursos autorizados e solicitados. ${ }^{669}$ Da mesma maneira, na hipótese de CI ou IGC inferiores a 3 (três), com base na análise fundamentada dos elementos de instrução do processo e da situação da instituição, os pedidos de credenciamento institucional para a modalidade de EAD, credenciamento de novos polos de apoio presencial e de autorização

\footnotetext{
${ }^{664}$ Decreto $^{\circ} 5.773 / 2006$, art. $17, \S 2^{\circ}$ e art. $31, \S 1^{\circ}$.

665 Portaria Normativa $\mathrm{n}^{\circ} 40 / 2007$, art. 13, parágrafo único.

${ }^{666}$ Portaria Normativa ${ }^{\circ} 40 / 2007$, art. 11-A, caput.

${ }^{667}$ Portaria Normativa $\mathrm{n}^{\circ}$ 40/2007, art. 11-A, $\S 1^{\text {o }}$, c/c Decreto $\mathrm{n}^{\circ} 5.773 / 2006$, art. $28, \S 2^{\circ}$.

${ }^{668} \mathrm{Na}$ ausência de CI, poderá ser considerado apenas o IGC da instituição (Portaria Normativa nº 40/2007, art. 11-A, $\S 4^{\circ}$ ).

${ }^{669}$ Portaria Normativa $n^{\circ} 40 / 2007$, art. $11-\mathrm{A}, \S \S 2^{\circ}$ e $3^{\circ}$.
} 
de cursos nessa modalidade poderão ser indeferidos independentemente de visita de avaliação in loco. ${ }^{670}$

Para os pedidos de autorização de cursos em EAD, poderá ser dispensada a avaliação in loco pelo INEP condicionada ao CI e IGC da instituição mais recentes iguais ou superiores a 4 (quatro), cumulativamente. ${ }^{671}$

No caso de pedidos de credenciamento de polos de apoio presencial, após a análise documental, poderá ser adotada a visita de avaliação in loco por amostragem, mediante despacho fundamentado, e condicionada, também, ao CI e IGC da instituição mais recentes iguais ou superiores a 4 (quatro), cumulativamente, devendo ser observadas as seguintes proporções: (a) até 5 (cinco) polos - a avaliação in loco será realizada em 1 (um) polo, à escolha da Secretaria; (b) de 5 (cinco) a 20 (vinte) polos - a avaliação in loco será realizada em 2 (dois) polos, um deles à escolha da Secretaria e o segundo, definido por sorteio; (c) mais de 20 (vinte) polos - a avaliação in loco será realizada em 10\% (dez por cento) dos polos, um deles à escolha da Secretaria e os demais, definidos por sorteio. ${ }^{672}$

Ressalte-se que os curso com CPC igual a 3 (três) ou 4 (quatro) têm o direito de requerer a avaliação in loco, tendo em vista seu potencial interesse na melhora conceitual. ${ }^{673}$ Para tanto, deverão protocolar pedido de renovação reconhecimento, no prazo de 30 (trinta) dias da publicação dos indicadores das grandes áreas correlatas do ENADE, acompanhado da taxa respectiva. Como resultado, será atribuído o CC, que poderá vir a manter o conceito, ser maior ou menor que o CPC, cabendo impugnação à CTAA, na forma do artigo 17. Caso o CC obtido seja insatisfatório, os cursos se submeterão ao procedimento previsto para cursos com CPC insatisfatório e instituições com IGC insatisfatório. ${ }^{674}$

Por outro lado, os cursos com CPC insatisfatório e as instituições com IGC insatisfatório em qualquer dos anos do ciclo deverão requerer renovação de reconhecimento ou recredenciamento, conforme o caso, no prazo de até 30 (trinta) dias da publicação do indicador, instruído com o plano de melhorias acadêmicas, contendo justificativa sobre eventuais deficiências que tenham dado causa ao indicador

\footnotetext{
${ }^{670}$ Portaria Normativa n ${ }^{\circ} 40 / 2007$, art. 11-B, $\S 2$.

${ }^{671}$ Portaria Normativa ${ }^{\circ} 40 / 2007$, art. 11-B, caput.

${ }^{672}$ Portaria Normativa n ${ }^{\circ} 40 / 2007$, art. 11-B, $\S 1^{\circ}$, c/c Portaria Normativa $n^{\circ} 40 / 2007$, art. 55, $\S 2^{\circ}$.

${ }^{673}$ Cabe aqui uma analogia com o conceito de interesse recursal, presente no Direito Processual Civil.

${ }^{674}$ Portaria Normativa n ${ }^{\circ}$ 40/2007, art. 35-B.
} 
insatisfatório, bem como medidas capazes de produzir melhora efetiva do curso ou instituição, em prazo não superior a um ano, aprovado pela Comissão Própria de Avaliação (CPA) da instituição, e do comprovante de recolhimento da taxa de avaliação in loco, salvo em hipótese de isenção legalmente estabelecida. ${ }^{675}$ Após essas medidas, será realizada avaliação in loco, após a qual será produzido o CC ou CI. ${ }^{676}$

É facultada ao Poder Público a prorrogação da validade dos atos de atos de recredenciamento de instituição, reconhecimento ou renovação de reconhecimento de curso em vigor, a cada ciclo avaliativo, por decisão do Ministro da Educação. Para tanto, é necessária a observância cumulativa dos seguintes requisitos: (a) indicador satisfatório: no caso de cursos, o CPC, e de instituição, os IGCs dos três anos que integram o ciclo; (b) ato autorizativo válido; e (c) inexistência de medida de supervisão em vigor. Para a tomada de tal medida, a CONAES poderá, ouvido o INEP, definir critérios de seleção de grupos de cursos ou instituições para submeterem-se a renovação do ato autorizativo naquele ciclo. ${ }^{677}$

\subsubsection{Avaliação in loco realizada pelo INEP}

Após a fase de análise documental, os procedimentos regulatórios da educação superior são encaminhados ao INEP para realização de avaliação in loco, ressalvadas as hipóteses de sua dispensa.

Após o despacho saneador satisfatório ou parcialmente satisfatório, relativo à análise documental, proferido pela Secretaria de Regulação e Supervisão da Educação Superior, os processos de autorização e reconhecimento de cursos, bem como credenciamento de instituições, e suas respectivas renovações serão encaminhados eletronicamente ao Instituto Nacional de Estudos e Pesquisas Educacionais Anísio Teixeira (INEP), para a realização da atividade de avaliação, de responsabilidade desta entidade. ${ }^{678}$ A atividade de avaliação da educação superior constitui referencial básico para os processos de regulação da educação superior, a fim de promover a melhoria de sua

\footnotetext{
${ }^{675}$ Portaria Normativa $n^{\circ} 40 / 2007$, art. 35-C, caput.

${ }^{676}$ Portaria Normativa n ${ }^{\circ} 40 / 2007$, art. 35-C, $\S 2^{\circ}$.

${ }^{677}$ Portaria Normativa $\mathrm{n}^{\circ}$ 40/2007, art. 35-A.

${ }^{678}$ Portaria Normativa n ${ }^{\circ} 40 / 2007$, art. 13-A.
} 
qualidade. ${ }^{679}$ Nos casos em que houver impugnação da avaliação, a avaliação será apreciada pela Comissão Técnica de Acompanhamento da Avaliação (CTAA). ${ }^{680}$

A tramitação do processo eletrônico no INEP se iniciará com a geração de código de avaliação no sistema e-MEC e a abertura de formulário eletrônico de avaliação para preenchimento pela instituição. ${ }^{681}$

Para cada processo, o INEP designará uma comissão de avaliação in loco, composta por três avaliadores (para avaliação de instituições) ou dois avaliadores (para avaliação de cursos), sorteados pelo sistema e-MEC dentre os integrantes do Banco de Avaliadores do Sistema Nacional de Avaliação da Educação Superior - SINAES (Basis).

As avaliações in loco devem ser realizadas no endereço constante do processo eletrônico de solicitação do ato autorizativo, ${ }^{682} \mathrm{em}$ data informada pelo INEP por meio do e-MEC, com a utilização, pela Comissão de Avaliadores, dos instrumentos de avaliação e seus respectivos formulários de avaliação eletrônicos - estes previamente preenchidos pelo requerente, no prazo de 15 (quinze dias), para cursos, e 30 (trinta) dias, para instituições, sob pena de arquivamento do processo. ${ }^{683}$ A Comissão deverá proceder ao registro fiel e circunstanciado das condições concretas de funcionamento da instituição ou curso, bem como aferir in loco a exatidão dos dados informados pela instituição, a fim de elaboração de relatório, com a atribuição do conceito da avaliação, ${ }^{684}$ sendo vedada à Comissão a realização de recomendações ou sugestões à instituição avaliada, sob pena de nulidade do relatório. $^{685}$

Após o recebimento do relatório, a Diretoria de Avaliação da Educação Superior do INEP atestará o trabalho realizado para fins de encaminhamento do pagamento do Auxílio Avaliação Educacional (AAE), em retribuição à participação em processo de avaliação. $^{686}$

\footnotetext{
${ }^{679}$ Decreto $^{\mathrm{o}} 5.773 / 2006$, art. $1^{\mathrm{o}}, \S 3^{\mathrm{o}}$.

${ }^{680}$ Portaria Normativa $\mathrm{n}^{\circ}$ 40/2007, art. 13-A.

${ }^{681}$ Portaria Normativa $n^{\circ} 40 / 2007$, art. 14, caput.

${ }^{682}$ Portaria Normativa $n^{\circ} 40 / 2007$, art. 14-C, parágrafo único.

${ }^{683}$ Portaria Normativa $n^{\circ} 40 / 2007$, art. 15 , caput e $\$ \S 1^{\circ}$ a $3^{\circ}$.

${ }^{684}$ Portaria Normativa $n^{\circ} 40 / 2007$, art. $15, \S \S 4^{\circ}$ a $6^{\circ}$.

${ }^{685}$ Portaria Normativa $\mathrm{n}^{\circ}$ 40/2007, art. 16, caput.

${ }^{686}$ Portaria Normativa n ${ }^{\circ} 40 / 2007$, art. $16, \S 4^{\circ}$ c/c Lei $11507 / 2007$, arts. $1^{\circ}$ a $5^{\circ}$.
} 


\subsubsection{Impugnação do resultado da avaliação}

Após a inserção do relatório da Comissão de Avaliadores no sistema e-MEC, o INEP notificará, simultaneamente, a instituição e a Secretaria de Regulação e Supervisão da Educação Superior, que terão o prazo comum de 60 (sessenta) dias para impugnar o resultado da avaliação. Havendo impugnação, será aberto prazo comum de 20 (vinte) dias para contrarrazões das Secretarias ou da instituição, conforme o caso. ${ }^{687}$

Caso haja impugnação, após decorrido o prazo para contrarrazões, o processo será submetido à Comissão Técnica de Acompanhamento da Avaliação (CTAA), que deverá apreciar conjuntamente apenas as manifestações da instituição e das Secretarias competentes inseridas no sistema e-MEC, e poderá decidir, de forma motivada, caso não entenda ser caso de manutenção do relatório impugnado: (a) pela reforma do parecer da Comissão de Avaliação, com alteração do conceito, para mais ou para menos, conforme se acolham os argumentos da instituição ou da Secretaria de Regulação e Supervisão da Educação Superior; (b) anulação do relatório e parecer, com base em falhas na avaliação, determinando a realização de nova visita. Não é possível à CTAA a realização de diligências ou verificações in loco. A decisão da CTAA é irrecorrível na esfera administrativa e encerra a fase de avaliação. ${ }^{688}$

A impugnação da avaliação tem natureza recursal, uma vez que enseja a reforma do relatório de avaliação. No entanto, tal recurso possui natureza distinta caso seja interposto pela instituição ou pela SERES. O interesse recursal que pode existir para a instituição é o de reformar no todo ou em parte o relatório de avaliação por motivos formais e/ou materiais que possam ter de alguma maneira a prejudicado na avaliação. No caso do recurso interposto pela Secretaria de Regulação e Supervisão da Educação Superior, o interesse recursal na impugnação reside na necessidade do relatório de avaliação conter fundamentos claros e objetivos para a tomada da decisão regulatória. Nesse caso, o recurso tem a natureza similar à dos embargos de declaração do processo civil, a fim de garantir que o relatório seja reformado por conter omissão, contradição ou obscuridade que torne difícil ou impossível a decisão administrativa regulatória. Dessa maneira, não deve prosperar a prática, que por vezes já ocorreu, da autoridade

\footnotetext{
${ }^{687}$ Portaria Normativa $n^{\circ} 40 / 2007$, art. $16, \S \S 1^{\text {o }}$ a $3^{\circ}$.

${ }^{688}$ Portaria Normativa $\mathrm{n}^{\circ} 40 / 2007$, art. 16.
} 
administrativa impugnar relatório de avaliação meramente pela existência de conceitos insatisfatórios.

\subsubsection{Avaliação como referencial para a regulação em sentido estrito}

Os resultados da avaliação de cursos e instituições no ciclo avaliativo constituem referencial básico dos processos de regulação e supervisão da educação superior, neles compreendidos o credenciamento e a renovação de credenciamento de instituições de educação superior, a autorização, o reconhecimento e a renovação de reconhecimento de cursos de graduação. ${ }^{689}$ A avaliação, como referencial básico para a regulação, resultará na atribuição de conceitos, conforme uma escala de cinco níveis. ${ }^{690}$

No entanto, o conceito obtido na avaliação não vincula a Secretaria de Regulação e Supervisão da Educação Superior, uma vez que, para decisão final a respeito de atos autorizativos relativos a cursos, ou parecer a respeito de atos autorizativos relativos a instituições, deverá ter como referencial o relatório de avaliação, mas também deverá considerar o conjunto de elementos que compõem o processo. ${ }^{691}$

\subsection{Regulação em sentido estrito da educação superior: decisão administrativa e respectivos recursos}

O Decreto $n^{\circ} 5.773 / 2006$ estabeleceu a articulação entre os fundamentos conceituais de direito material e processual - a avaliação como referencial básico da regulação - de tal forma que, diferentemente do que ocorria anteriormente, a avaliação insatisfatória gera consequências, impedindo a renovação automática do reconhecimento dos cursos ou recredenciamento de instituições. ${ }^{692}$ Os elementos constantes da avaliação, desta maneira, constituem os parâmetros a serem sopesados para a decisão administrativa orientada pelo princípio da proporcionalidade, conforme aponta Marçal Justen Filho:

"A decisão deverá ser orientada pelo princípio da proporcionalidade, o que envolve a necessidade de uma avaliação de custos e benefícios. Será inválida decisão administrativa

\footnotetext{
${ }^{689}$ Lei do SINAES, art. $2^{\circ}$, parágrafo único.

${ }^{690}$ Decreto no $^{\circ} 5.773 / 2006$, art. 59, $\S 3^{\circ}$.

${ }^{691}$ Decreto no $^{\circ} 5.773 / 2006$, art. 17, $\$ 4^{\circ}$.

${ }^{692}$ Cf. Maria Paula Dallari Bucci, "Processo administrativo eletrônico e informação pública".
} 
destituída dessa ponderação, mesmo que produzida no exercício de competência discricionária." 693

Após a realização da avaliação in loco, ou presentes as condições para decisão administrativa baseada em indicadores de qualidade, o trâmite do processo eletrônico segue para o Diretor de Regulação da Educação Superior para apreciação, que compreende os elementos da instrução documental, a avaliação do INEP (ou os indicadores de qualidade) e o mérito do pedido, preparando parecer no sentido de deferimento ou indeferimento. Caso o Diretor considere necessária a complementação de informação ou esclarecimento em ponto específico, poderá baixar o processo em diligência. ${ }^{694}$

Com o parecer do Diretor de Regulação da Educação Superior, o trâmite segue para o Secretário de Regulação e Supervisão da Educação Superior, que proferirá a decisão - no caso de pedido de autorização, reconhecimento ou renovação de reconhecimento - ou encaminhará ao $\mathrm{CNE}$ os pedidos de credenciamento ou de recredenciamento, para decisão. ${ }^{695}$ Nos casos em que cabe decisão do Secretário, desta poderá ser interposto recurso administrativo ao CNE, no prazo de 30 (trinta) dias. ${ }^{696}$

Nos casos em que cabe decisão do CNE, a deliberação é tomada pela Câmara de Educação Superior, em ato único, versando sobre o mérito do pedido. Dessa decisão, cabe recurso ao pleno do conselho. ${ }^{697}$ Após a decisão do CNE, o trâmite processual segue ao Ministro da Educação para homologação. ${ }^{698}$

\subsection{Supervisão da educação superior}

A supervisão da educação superior tem o objetivo de zelar pela conformidade da oferta da educação superior com a legislação vigente, nos termos dos atos autorizativos, verificando a ocorrência de possíveis irregularidades no funcionamento de instituição ou cursos superiores. Essa atividade visa a induzir a melhoria da qualidade da educação superior, resguardando o interesse dos envolvidos e preservando, na medida do possível, as atividades em funcionamento. Trata-se, portanto, de manifestação de atividade

\footnotetext{
${ }^{693}$ Marçal Justen Filho, Curso de Direito Administrativo, p. 334.

${ }^{694}$ Portaria Normativa $n^{\circ} 40 / 2007$, artigo 18 , caput e $\S 1^{\text {o. }}$.

${ }^{695}$ Portaria Normativa ${ }^{\circ} 40 / 2007$, artigo $18, \S \S 2^{\circ}$ e $3^{\circ}$.

${ }^{696}$ Decreto no $^{\circ} 5.773 / 2006$, artigos 33 e 40.

${ }^{697}$ Decreto $^{\circ}{ }^{\circ} 5.773 / 2006$, artigo 18.

${ }^{698}$ Decreto n $^{\circ} 5.773 / 2006$, artigo 19.
} 
administrativa ordenadora - ou, em uma visão mais tradicional - decorrente do exercício do poder de polícia. ${ }^{699}$

A Secretaria de Regulação e Supervisão da Educação Superior, por meio da Diretoria de Supervisão da Educação Superior, exerce as atividades relativas à supervisão dos cursos superiores de graduação e tecnológicos. Para tanto, pode, nos limites da lei, pode determinar a apresentação de documentos complementares ou a realização de auditoria. $^{700}$

O procedimento de supervisão pode se iniciar por meio de representação circunstanciada de alunos, professores e pessoal técnico-administrativo das instituições, admitida sua formulação por meio dos respectivos órgãos representativos, ${ }^{701}$ bem como por outras pessoas ou entidades interessadas. O procedimento também poderá ser instaurado de ofício, pela Secretaria de Regulação e Supervisão da Educação Superior, quando esta tiver ciência de irregularidade que lhe caiba sanar e punir. ${ }^{702}$

O procedimento de supervisão também poderá ser envolver mais de um curso ou instituição, submetidos a uma situação fática ou jurídica comum: são os casos dos procedimentos de supervisão especial ou extraordinária, por meio dos quais cursos ou instituições são agrupados de acordo com algum critério escolhido. Esse procedimento foi utilizado para supervisionar 20 (vinte) cursos de Medicina, 89 (oitenta e nove) cursos de Direito, 49 (quarenta e nove) cursos de Pedagogia e 11 (onze) cursos de Normal Superior que obtiveram conceitos insatisfatórios decorrentes do ENADE; bem como em 123 (cento e vinte e três) universidades e centros universitários que não atendiam aos percentuais mínimos exigidos quanto à titulação e regime de trabalho do corpo docente.

A representação deve conter a qualificação do representante, a descrição clara e precisa dos fatos a serem apurados e a documentação pertinente, bem como os demais elementos relevantes para o esclarecimento do seu objeto. ${ }^{703}$ Com base nesses elementos, o Secretário de Regulação e Supervisão da Educação Superior dará ciência da representação à instituição, que poderá, em dez dias, manifestar-se previamente pela insubsistência da representação ou requerer a concessão de prazo para saneamento de deficiências. Com

\footnotetext{
${ }^{699}$ Cf. Magno Federici Gomes, "Educação superior privada como serviço de utilidade pública”, p. 280.

${ }^{700}$ Decreto $^{\circ} 5.773 / 2006$, artigo 45 , caput e $\S 1^{\circ}$.

${ }^{701}$ Decreto no 5.773/2006, artigo 46, caput.

${ }^{702}$ Decreto n $^{\circ} 5.773 / 2006$, artigo 46, $\S 3^{\circ}$.

${ }^{703}$ Decreto $^{\circ} 5.773 / 2006$, artigo $46, \S \S 1^{\circ}$.
} 
base na manifestação da instituição, o Secretário decidirá pela admissibilidade da representação, instaurando processo administrativo ou concedendo prazo para saneamento de deficiências. ${ }^{704}$

A hipótese da concessão de prazo para saneamento de deficiências será analisada em subcapítulo próprio. Caso a decisão seja no sentido de instauração de processo administrativo para aplicação de penalidades, esta se dá por meio de portaria do Secretário, da qual deve constar: (a) identificação da instituição e de sua mantenedora; (b) o resumo dos fatos objeto das apurações, e, quando for o caso, das razões de representação; (c) a informação sobre a concessão de prazo para saneamento de deficiências e as condições de seu descumprimento ou cumprimento insuficiente; (d) outras informações pertinentes; (e) consignação da penalidade aplicável; e (f) a determinação de notificação do representado. Nessa fase, não há a possibilidade de concessão de novo prazo para saneamento de deficiências. ${ }^{705}$

Em obediência ao princípio do contraditório e ampla defesa, o representado tomará ciência do processo, para, no prazo de 15 (quinze) dias, apresentar sua defesa, envolvendo as matérias de fato e de direito pertinentes. ${ }^{706}$ Após o recebimento da defesa, o Secretário deve apreciar o conjunto dos elementos do processo e proferir sua decisão motivada, arquivando o processo ou aplicando alguma das penalidades administrativas: (a) desativação de cursos e habilitações; (b) intervenção; (c) suspensão temporária de prerrogativas da autonomia; ou (d) descredenciamento. ${ }^{707}$ Da decisão do Secretário cabe recurso ao CNE, no prazo de 30 (trinta) dias. A decisão administrativa final depende de homologação por portaria expedida pelo Ministro da Educação.

A relação restrita de sanções administrativas aplicáveis gerou uma questão controversa diante de algumas situações práticas: qual a sanção aplicável a deficiências comprovadas em determinados cursos, após instrução processual, que, por sua gravidade, seriam passíveis de aplicação de alguma penalidade, mas que não mereceriam a pena de desativação de curso? Para esses casos, em observância ao princípio da proporcionalidade, foi adotada a possibilidade de aplicação da penalidade de redução de vagas autorizadas,

\footnotetext{
${ }^{704}$ Decreto $^{\mathrm{o}} 5.773 / 2006$, artigo 47.

${ }^{705}$ Decreto $^{\circ}$ 5.773/2006, artigo 50.

${ }^{706}$ Decreto $^{\circ}$ 5.773/2006, artigo 51.

${ }^{707}$ LDB, artigo 46, $\S 1^{\circ}$. Decreto $n^{\circ} 5.773 / 2006$, artigo 52.
} 
que, de certa maneira, equivaleria à modulação de efeito, por meio da aplicação parcial da penalidade de desativação de curso.

\subsection{Termo de saneamento de deficiências e protocolo de compromisso}

A Lei de Diretrizes e Bases da Educação estabelece que, em decorrência da avaliação, a instituição tem direito a um prazo de saneamento de deficiências, após o qual é realizada nova avaliação, da qual poderá resultar a aplicação de penalidades administrativas. ${ }^{708} \mathrm{Na}$ mesma linha, a Lei do SINAES estabelece que os resultados de avaliação considerados insatisfatórios ensejarão a celebração de protocolo de compromisso, de caráter público e disponível a todos os interessados, a ser firmado entre a instituição de educação superior e o Ministério da Educação. ${ }^{709}$

Embora, de acordo com a legislação mencionada, saneamento de deficiências e protocolo de compromisso sejam decorrentes de avaliação, o Decreto $\mathrm{n}^{\mathrm{o}}$ 5.773/2006 regulamenta o saneamento de deficiências como decorrente da supervisão, ${ }^{710}$ e o protocolo de compromisso, da avaliação. ${ }^{711}$ Isso decorre do fato do termo avaliação ter sido empregado, na LDB, em uma acepção ampla, que abrangeria a supervisão - expressão não empregada por essa lei.

$\mathrm{Na}$ realidade, existe fungibilidade entre esses dois institutos. O saneamento de deficiências, se aceito pela instituição nos termos propostos pela Secretaria de Regulação e Supervisão da Educação Superior, deve ser reduzido a termo. Como o decreto não menciona os elementos que devem constar deste ajuste, é razoável a utilização dos elementos que constam do protocolo de compromisso, previstos em seu artigo 61. A peculiaridade existente no saneamento de deficiências decorrente da supervisão é o estabelecimento do prazo máximo de 12 (doze) meses, ${ }^{712}$ após o qual pode ser realizada nova avaliação in loco. ${ }^{713}$

\footnotetext{
${ }^{708}$ LDB, artigo 46, $\S 1^{\circ}$.

${ }^{709}$ Lei do SINAES, art. 10.

${ }^{710}$ Decreto n $^{\circ} 5.773 / 2006$, artigos 47 a 52.

${ }^{711}$ Decreto n$^{\circ} 5.773 / 2006$, artigos 60 a 64 .

${ }^{712}$ Decreto n $^{\circ} 5.773 / 2006$, artigo 48, § $1^{\circ}$.

${ }^{713}$ Decreto no $^{\circ} 5.773 / 2006$, artigo 49.
} 
O protocolo de compromisso, decorrente da obtenção de conceitos insatisfatórios nos processos periódicos de avaliação, deverá conter: (a) o diagnóstico objetivo das condições da instituição; (b) os encaminhamentos, processos e ações a serem adotados pela instituição com vistas à superação das dificuldades detectadas; (c) a indicação expressa de metas a serem cumpridas e, quando couber, a caracterização das respectivas responsabilidades dos dirigentes; (d) o prazo máximo para seu cumprimento; e (e) a criação, por parte da instituição de educação superior, de comissão de acompanhamento do protocolo de compromisso. ${ }^{714}$

A celebração de protocolo de compromisso suspende o fluxo do processo regulatório, até a realização da avaliação que ateste o cumprimento das exigências contidas no ajuste. $^{715}$

Existe previsão expressa de, durante a vigência de protocolo de compromisso, poder ser aplicada pela Secretaria de Regulação e Supervisão da Educação Superior medida cautelar de suspensão preventiva da admissão de novos alunos em cursos, visando a evitar prejuízo a novos alunos. ${ }^{716}$ Nesse ponto há mais um exemplo que demonstra a fungibilidade entre celebração de protocolo de compromisso e termo de saneamento de deficiências, pois se consolidou o entendimento de que a medida cautelar também pode ser utilizada em decorrência do processo de supervisão, uma vez que, nesse caso, também pode haver indicação de ocorrência de irregularidade potencialmente causadora de prejuízo a novos alunos.

Esgotado o prazo do protocolo de compromisso, a instituição será submetida a nova avaliação in loco pelo INEP, para verificar o cumprimento das metas estipuladas, com vistas à alteração ou à manutenção do conceito. Aqui está presente uma diferença em relação ao termo de saneamento de deficiências, no qual a realização ou não de nova visita fica a critério discricionário da autoridade administrativa.

Nota-se que tanto a celebração de termo de saneamento de deficiências, quanto a de protocolo de compromisso, apontam para o fato de que a atuação da autoridade regulatória na educação superior, embora tenha fortes elementos caracterizados como poder de polícia, inclina-se pelo fomento, uma vez que oferece às instituições a

\footnotetext{
${ }_{714}^{714}$ Decreto $\mathrm{n}^{\mathrm{o}} 5.773 / 2006$, artigo 61, caput.

${ }^{715}$ Decreto no $^{\circ} 5.773 / 2006$, artigo 61, § $1^{\circ}$.

${ }^{716}$ Decreto $^{\circ} 5.773 / 2006$, artigo $61, \S 1^{\circ}$ c/c artigo $11, \S 3^{\circ}$.
} 
possibilidade de ajustar com o Poder Público medidas visando à melhoria da qualidade da educação antes de serem submetidas a processo administrativo para aplicação de penalidades. Essa sistemática reflete o interesse público não em aplicar a priori penalidades sobre cursos e instituições, mas em estimular a melhoria da qualidade da educação superior. 


\section{Capítulo 6 REgULAÇÃO COMO GARANTIA DO DIREITO À EDUCAÇÃO SUPERIOR}

\subsection{Regulação e sua relação com as políticas públicas de democratização do acesso à educação superior}

Há políticas públicas que visam à democratização do acesso à educação superior e se relacionam diretamente com a atividade de regulação nessa área. Enquadramse nesse caso o Programa Universidade para Todos (ProUni) e o Fundo de Financiamento ao Estudante do Ensino Superior (FIES): políticas públicas de acesso à educação superior que devem ser efetivados por meio de cursos e instituições com qualidade satisfatória, tendo em vista que o direito à educação não se resume a aspectos meramente formais, pois, em termos substanciais, visa ao pleno desenvolvimento de todas as potencialidades humanas. Silke Weber estabelece a relação entre a avaliação e políticas de democratização do acesso à educação superior:

"Desse modo, a avaliação institucional deveria ser entendida como parte das políticas públicas de educação superior voltadas para a construção de um sistema de educação brasileiro vinculado ao projeto de sociedade democrática.

$[\ldots]$

Iniciativas como as do Programa Universidade para Todos (PROUNI), por exemplo, motivaram inovações no âmbito das instituições, tanto do ponto de vista da formação (inserção de atividades culturais, uso da informática, domínio de idiomas, práticas de leitura e de compreensão de texto), como do ponto de vista financeiro (bolsas de estudo, empréstimo, mensalidade flexível) para assegurar a permanência de estudantes, cujo rebatimento no seu desempenho e na sua autoestima começa a ser desvelado". ${ }^{717}$

Por essa razão, passa-se a analisar a relação existente entre a regulação da educação superior e as políticas públicas mencionadas.

717 Silke Weber, "Avaliação e regulação da educação superior: conquistas e impasses", Educação \& Sociedade 113 (2010), p. 1265. 


\title{
6.1.1. Programa Universidade para Todos (ProUni)
}

De 1988 a 2004, as instituições de educação superior sem fins lucrativos, amparadas pelo artigo 150, VI, “c”, e artigo 195, § $7^{\circ}$, da Constituição, ${ }^{718}$ gozaram de imunidades fiscais sem qualquer contrapartida e regulação estatal. A regulação de tais benefícios fiscais constitucionalmente concedidos a instituições demorou dezesseis anos para ser estabelecida pelo ordenamento jurídico. ${ }^{719}$ A ausência de regulamentação da imunidade prevista no artigo $195, \S 7^{\circ}$, fez com que as instituições delas gozassem sem a necessidade de contrapartidas, amparadas no julgamento, pelo Supremo Tribunal Federal, do Mandado de Injunção n⿳0 232, relatado pelo Ministro Moreira Alves:

\begin{abstract}
"Mandado de injunção. - Legitimidade ativa da requerente para impetrar mandado de injunção por falta de regulamentação do disposto no $\S 7^{\circ}$ do artigo 195 da Constituição Federal. Ocorrência, no caso, em face do disposto no artigo 59 do ADCT, de mora, por parte do Congresso, na regulamentação daquele preceito constitucional. Mandado de injunção conhecido, em parte, e, nessa parte, deferido para declarar-se o estado de mora em que se encontra o Congresso Nacional, a fim de que, no prazo de seis meses, adote ele as providencias legislativas que se impõem para o cumprimento da obrigação de legislar decorrente do artigo $195, \S 7^{\circ}$, da Constituição, sob pena de, vencido esse prazo sem que essa obrigação se cumpra, passar o requerente a gozar da imunidade requerida."
\end{abstract}

A regulamentação dessas imunidades foi promovida pela Medida Provisória ${ }^{\circ}$ 213, de 10 de setembro de 2004, posteriormente convertida na Lei $\mathrm{n}^{\circ} 11.096$, de 13 de janeiro de 2005, que instituiu o Programa Universidade para Todos (ProUni), destinado à concessão de bolsas de estudo integrais e parciais para estudantes de cursos superiores, em instituições privadas de ensino superior, com ou sem fins lucrativos. Os beneficiários desse programa são os brasileiros não portadores de diploma de curso superior, com renda

${ }^{718}$ Constituição da República Federativa do Brasil:

Art. 150. Sem prejuízo de outras garantias asseguradas ao contribuinte, é vedado à União, aos Estados, ao Distrito Federal e aos Municípios:

$[\ldots]$

VI - instituir impostos sobre:

$\{\ldots]$

c) patrimônio, renda ou serviços dos partidos políticos, inclusive suas fundações, das entidades sindicais dos trabalhadores, das instituições de educação e de assistência social, sem fins lucrativos, atendidos os requisitos da lei;

[...]

Art. 195. A seguridade social será financiada por toda a sociedade, de forma direta e indireta, nos termos da lei, mediante recursos provenientes dos orçamentos da União, dos Estados, do Distrito Federal e dos Municípios, e das seguintes contribuições sociais:

[...]

$\S 7^{\circ}$ - São isentas de contribuição para a seguridade social as entidades beneficentes de assistência social que atendam às exigências estabelecidas em lei."

${ }^{719}$ Cf. Eliane Ferreira de Sousa, Direito à educação, p. 115. 
familiar mensal per capita baixa. ${ }^{720}$ Além do critério relativo à renda, para fazer jus à bolsa, o estudante deve ter cursado o ensino médio integralmente em escola da rede pública ou em instituições privadas na condição de bolsista integral, ser portador de deficiência ou ser professor da rede pública de ensino, para os cursos de licenciatura, normal superior e pedagogia, destinados à formação do magistério da educação básica (nesse caso, independentemente da renda). Além disso, o beneficiário do programa é préselecionado pelos resultados obtidos no Exame Nacional do Ensino Médio (ENEM), garantindo a observância do artigo $208, \mathrm{~V}$, da Constituição. ${ }^{721}$

Os procedimentos de adesão das instituições de educação superior ao programa se dá por meio do Sistema do ProUni (SISPROUNI) que exige das instituições uma certificação eletrônica como forma de garantir o controle e a segurança do processo.

Existem alguns fatores que implicam na influência recíproca entre a regulação da educação superior e o ProUni. Por aderir ao programa, ${ }^{722}$ as instituições ficam isentas de alguns tributos, ${ }^{723}$ mas, em contrapartida, devem manter um padrão de qualidade satisfatório, pois o curso considerado insuficiente deve ser desvinculado do programa, sem prejuízo para o estudante já matriculado. Para tanto, o curso é considerado insuficiente segundo critérios de desempenho no Sistema Nacional de Avaliação da Educação Superior - SINAES, por duas avaliações consecutivas. ${ }^{724}$ Dessa maneira, para permanecer no programa, as instituições devem manter padrões satisfatórios de qualidade.

Por outro lado, a adesão ao programa e a concessão de bolsas, em si, já pode colaborar para a melhoria dos padrões de qualidade das instituições de educação superior aderentes ao programa. Eliane Ferreira de Sousa aponta que, apesar da nota mínima no ENEM para obtenção de bolsa ter sido fixada em 45 pontos, a nota média dos beneficiados atingiu marca superior a 60 pontos e manteve-se sempre superior à pontuação obtida pelos alunos egressos de escolas privadas, bem como o desempenho dos bolsistas do ProUni é

\footnotetext{
${ }^{720}$ A renda familiar mensal per capita não pode exceder o valor de até 1 (um) salário-mínimo e 1/2 (meio), para a bolsa integral, e de até 3 (três) salários-mínimos, para bolsa parcial

721 “Art. 208. O dever do Estado com a educação será efetivado mediante a garantia de:

$[\ldots]$

V - acesso aos níveis mais elevados do ensino, da pesquisa e da criação artística, segundo a capacidade de cada um;'

${ }^{722}$ A adesão ao ProUni é regulada pela Lei no 11.128 , de 28 de junho de 2005.

${ }^{723}$ Essa isenção refere-se aos seguintes tributos: a) Imposto de Renda das Pessoas Jurídicas; b) Contribuição Social sobre o Lucro Líquido; c) Contribuição Social para Financiamento da Seguridade Social; d) Contribuição para o Programa de Integração Social (Lei no 11.096/2005, artigo $8^{\circ}$ ).

${ }^{724}$ Esse critério foi inserido na Lei do ProUni pela Lei ${ }^{\circ} 11.509 / 2007$.
} 
sistematicamente superior ao dos demais no Exame Nacional de Desempenho dos Estudantes (ENADE). ${ }^{725}$

Nara Torrecilha Ferreira, em estudo a respeito da efetividade do ProUni, identificando os fatores que influenciam os resultados de políticas públicas voltadas ao ensino superior e analisando em que medida o PROUNI contribui para a ampliação do acesso à educação superior, identificou que o desempenho geral dos alunos bolsistas nas edições do ENADE, de 2006 a 2009, demonstra-se superior ao desempenho dos alunos não bolsistas em todas as provas, apesar de ainda persistirem críticas, por parte de alguns autores, relacionadas ao suposto despreparo dos bolsistas para acompanhar o curso de graduação: ${ }^{726}$

"Os dados demonstram que os estudantes selecionados para a bolsa integral obtêm os melhores resultados no ENADE e atingem os grupos mais excluídos do ensino superior. Por isso, podese constatar que a seleção via ENEM, de acordo com os critérios estabelecidos para as bolsas integrais, realmente seleciona os melhores alunos, que não poderiam cursar a graduação por falta de oportunidade e de condições financeiras, e não por falta de conhecimento."727

Contudo, a relação entre o Programa Universidade para Todos e a regulação da educação superior ainda precisa ser aperfeiçoada. Em grande medida, o sistema eletrônico do ProUni (SISPROUNI) ainda não tem uma relação adequada com o Sistema e-MEC. Um exemplo disso é o fato de que, por ocasião da inscrição de candidatos a bolsas concedidas pelo programa, na qual os estudantes realizam a opção pelos cursos pretendidos, é apresentada, na página eletrônica de inscrição, a relação de cursos e número de bolsas disponíveis, ${ }^{728}$ sem, no entanto, apresentar o conceito de avaliação dos cursos e instituições. ${ }^{729}$

Dado que nem todas as pessoas estão informadas da possibilidade de consultar conceitos de cursos e instituições no Cadastro e-MEC, a apresentação dessas informações no momento da escolha dos cursos na inscrição para bolsas do ProUni seria fundamental para consolidar a relação entre esse programa e o sistema regulatório da educação superior: a procura pelos cursos com melhores conceitos seria maior, permitindo, assim, a seleção de

${ }_{725}$ Cf. Eliane Ferreira de Sousa, Direito à educação, pp. 116-117.

${ }^{726}$ Cf. Nara Torrecilha Ferreira, Programa Universidade para Todos: uma avaliação sobre efetividade da política pública, Dissertação de Mestrado. Faculdade de Economia, Administração, Contabilidade e Ciência da Informação e Documentação, Universidade de Brasília, Brasília, 2012, p. 94.

${ }^{727}$ Nara Torrecilha Ferreira, Programa Universidade para Todos, p. 97

${ }^{728}$ Disponível em http://prounialuno.mec.gov.br/consulta/publica, acesso em 20.01.2013.

${ }^{729}$ Esse fato ocorreu ainda no último período de inscrições para o ProUni, de 17 a 21 de janeiro de 2013. 
alunos mais bem preparados, colaborando para a manutenção de índices de qualidade satisfatórios. As instituições com cursos com conceitos insatisfatórios, por outro lado, tenderiam a promover ações de melhoria da qualidade para não perderem alunos e não correrem o risco de exclusão do programa.

\subsubsection{Fundo de Financiamento ao Estudante do Ensino Superior (FIES)}

Da mesma maneira que o ProUni, outra política pública, o Fundo de Financiamento ao Estudante do Ensino Superior (FIES), instituído pela Lei $\mathrm{n}^{\circ} 10.260$, de 12 de julho de 2001, também condiciona a matrícula em cursos com a avaliação positiva, ${ }^{730}$ assim considerados aqueles que, nos termos do SINAES, obtiverem conceito maior ou igual a 3 (três) no Exame Nacional de Desempenho dos Estudantes. ${ }^{731}$ Os cursos que não atingirem essa média ficarão desvinculados do $\operatorname{FIES}^{732}$.

Nota-se, dessa maneira, que ambas as políticas públicas mencionadas buscam a democratização do acesso à educação superior, com objetivo de alcançar padrões mínimos de qualidade. Ocorre, nesses casos, uma articulação das normas de regulação da educação superior com políticas públicas garantidoras do direito social à educação. Por essa razão, pode-se afirmar que a regulação da educação superior apresenta-se como um mecanismo importante para a efetivação do direito a educação nesse nível.

\subsection{Regulação da educação superior e diminuição de desigualdades regionais na oferta da educação superior}

Um dos desafios da regulação da educação superior no país é o de promover o desenvolvimento regional, a fim de atingir o objetivo fundamental, constitucionalmente estabelecido, de diminuição das desigualdades regionais. Nesse particular, cabe uma reflexão a respeito dos critérios de avaliação na atividade regulatória: se forem uniformes e fixos para todo o território nacional, poderão constituir obstáculo à criação e manutenção de instituições e cursos superiores em algumas regiões, colaborando com a perpetuação da situação de desigualdade. No entanto, por outro lado, o estabelecimento de níveis de exigência diferenciados para cada região poderia instituir um sistema que se estruturaria

\footnotetext{
${ }^{730}$ Lei $\mathrm{n}^{\mathrm{o}} 10.260 / 2001$, artigo $1^{\mathrm{o}}$, caput.

${ }^{731}$ Lei $^{\circ} 10.260 / 2001, \operatorname{artigo1}^{\circ}, \S 2^{\circ}$.

${ }^{732}$ Lei n $^{\mathrm{o}} 10.260 / 2001$, artigo $1^{\circ}, \S 3^{\circ}$.
} 
com base em cursos de "primeira linha", nas regiões mais desenvolvidas, e cursos de "segunda linha", nas regiões menos desenvolvidas, da mesma maneira, perpetuando a situação de desigualdade. A atividade regulatória do setor, portanto, deve estar atenta aos objetivos de diminuição das desigualdades regionais:

“A avaliação deve ter também o papel de fortalecer estratégias e políticas coerentes com os grandes objetivos nacionais. Por isso, é importante que o sistema de avaliação ponha em foco de reflexão e análise os temas da pertinência e da relevância social dos conhecimentos e da formação, da democratização da educação e, portanto, da equidade, do acesso e da permanência, tendo como referência os valores primordiais e as prioridades da sociedade e das comunidades regionais." 733

De fato, a avaliação baseada em indicadores de qualidade e instrumentos de avaliação padronizados é realizada de forma uniforme em todo o território nacional. Por essa razão, o sistema regulatório deve permitir à autoridade a possibilidade de sopesamento dos indicadores de qualidade, visando à implementação de uma política regulatória compatível com o objetivo de redução das desigualdades regionais. Nesse sentido, apresenta-se pertinente a observação de Eduardo Molan Gaban:

\footnotetext{
"Este aparente paradoxo existente entre eficiência econômica e "eficiência" social (ou eficiência distributiva), deve ser sopesado com base em ditames da Constituição e princípios que norteiam o ordenamento jurídico, devendo a autoridade governamental realizar o julgamento da medida de prevalência de uma sobre outra, ou, sempre que possível, realizar sua adequação.",734
}

Para tanto, entendemos que dentro do sistema regulatório da regulação superior há espaço para o desenvolvimento de políticas de promoção da qualidade associadas a políticas de desenvolvimento regional. Diante de algum resultado de avaliação considerado insatisfatório, em decorrência de particularidades regionais, é possível, por meio da celebração de protocolo de compromisso, ${ }^{735}$ o estabelecimento de medidas de fomento para a promoção progressiva do aumento da qualidade na educação superior.

Podemos tomar como exemplo hipotético um curso avaliado de forma insatisfatória, em grande medida por conta da titulação, decorrente da ausência de mestres e doutores no corpo docente. A instituição alegaria que em seu estado da Federação não há

\footnotetext{
733 José Dias Sobrinho, “Avaliação e transformações da educação superior brasileira (1995-2009): do Provão ao SINAES”. Avaliação 15 (1) (2010), p. 221.

${ }^{734}$ Eduardo Molan Gaban, "Regulação econômica e assimetria de informação", p. 123.

${ }^{735}$ Cf. 5.8 .
} 
programas de pós-graduação stricto sensu na área, o que dificultaria a contratação de professores titulados. Nesse caso, o protocolo de compromisso poderia conter metas de titulação docente, com a apresentação de uma política institucional de qualificação, por meio da qual a instituição se comprometeria a aumentar a titulação de seu corpo docente de forma progressiva.

Dessa forma, compete à autoridade reguladora o exercício de sua atividade dentro do grau de discricionariedade conferido pela lei, com base em critérios amparados pelo princípio da proporcionalidade, para fomentar o desenvolvimento regional da educação superior.

\subsection{Regulação da educação superior e sua relação com políticas de efetivação do direito à educação}

O estabelecimento de um sistema regulatório estatal da educação superior, nos moldes do implementado nos últimos tempos, deve contribuir para o cumprimento das metas de ampliação de acesso à educação superior de qualidade, nos termos do Plano Nacional de Educação, promovendo a inclusão social.

Nas instituições de educação superior, em geral, há uma tensão interna entre os setores acadêmicos - que aspiram a melhorias qualitativas - e os setores administrativofinanceiros, que costumam colocar óbices a medidas de melhoria de qualidade que importem em maiores que, inevitavelmente, conduzem a maiores custos. O papel da regulação da educação superior é, em grande medida, fortalecer a posição do primeiro setor mencionado em relação ao segundo. Nesse sentido, apontam Vladmir Oliveira da Silveira e Irene Patrícia Nohara:

“O sistema de supervisão das instituições de ensino superior deve ser, portanto, arejado por regras que mitiguem a lógica de competição e acumulação do capitalismo contemporâneo, baseada em critérios meramente economicistas de eficiência, para que a cultura de qualidade na avaliação inspire-se em valores efetivamente democráticos.”,736

A existência de um marco regulatório da educação superior, dessa maneira, colabora com o aumento da oferta de educação superior, baseada em padrões de qualidade

\footnotetext{
736 Vladmir Oliveira da Silveira / Irene Patrícia Nohara, "Supervisão do ensino superior de direito no contexto federativo e complexidades do controle da pós-graduação stricto sensu”, p. 289.
} 
satisfatórios, com a gradativa inclusão da cultura de avaliação nas instituições brasileiras, devendo ser encarado como uma política pública estruturada e permanente:

"É preciso pensar em termos de programas estruturados que combinem de forma racional as dimensões política, econômica, jurídica e de gestão da ação governamental, resultando no atendimento de direitos em escala ampla, num horizonte temporal claro e conscientemente situados em relação ao processo político-eleitoral. Reclama-se uma compreensão sistemática sobre a expressão organizativa do Estado que outorga prestações, de modo que se tenha sempre presente a necessidade de legitimação na sua condução." ${ }^{\text {737 }}$

Evidentemente, a expansão do acesso à educação superior não deve ser realizada apenas pelo aumento da participação do setor privado, por meio de políticas públicas de garantia de acesso fomentadas pelo Estado. Cabe ao Estado o papel principal na expansão dessa oferta, por meio da criação de vagas em instituições públicas, segundo os padrões de qualidade estabelecidos no sistema regulatório. Para tanto, é muito importante o estabelecimento do investimento de 10\% (dez por cento) do Produto Interno Bruto na educação pública, nos termos do projeto de lei que pretende instituir o novo Plano Nacional de Educação, ainda em tramitação. ${ }^{738}$ Cumpre ao sistema regulatório da educação superior a tarefa de garantir que a expansão de oferta de ensino neste nível, tanto pelo Estado, quanto pela iniciativa privada, se desenvolva dentro de parâmetros de qualidade comuns, na busca da garantia do acesso à educação superior em padrões equitativos, na maior medida possível.

Da mesma maneira, a regulação da educação superior deve ter como objetivo à efetivação do direito à educação como um todo, considerado em uma dimensão sistêmica. Tradicionalmente, é colocada uma falsa oposição entre educação básica e educação superior: diante da falta de recursos, alega-se que cabe ao gestor público optar pela primeira. ${ }^{739}$ No entanto, cabe ao sistema educacional brasileiro a superação dessa falácia, que nos coloca em uma encruzilhada: não há como aprimorar a educação básica sem a existência de cursos superiores de qualidade, nos quais serão formados os professores; da mesma maneira que, sem alunos formados em escolas básicas de qualidade, torna-se difícil a tarefa de garantir padrões de qualidade satisfatórios em instituições e cursos superiores.

\footnotetext{
${ }^{737}$ Maria Paula Dallari Bucc,. “O art. 209 da Constituição 20 anos depois”, p. 785.

${ }^{738}$ Cf. 2.4.

739 Cf. Fernando Haddad, O Plano de Desenvolvimento da Educação: razões, princípios e programas, Brasília: INEP, 2008, p. 6.
} 
Essa questão só pode ser superada por meio do desenvolvimento de políticas educacionais baseadas em uma visão sistêmica:

"Visão sistêmica implica, portanto, reconhecer as conexões intrínsecas entre educação básica, educação superior, educação tecnológica e alfabetização e, a partir dessas conexões, potencializar as políticas de educação de forma a que se reforcem reciprocamente." ${ }^{\text {740 }}$

Por essa razão, cabe ao sistema regulatório da educação superior um importante papel, dentro do sistema educacional, de garantia da efetivação do direito à educação em todos os seus níveis.

${ }^{740}$ Fernando Haddad, O Plano de Desenvolvimento da Educação, p. 9. 


\section{CONCLUSÃO}

A presente tese pretendeu estudar e sistematizar o novo marco regulatório da educação superior, entendido como uma série de inovações normativas, destinadas a dotar o Poder Público de mecanismos para efetivar o dispositivo contido no artigo 209 da Constituição, que condiciona o desempenho da atividade educacional à avaliação de qualidade e autorização estatal, bem como analisar, em que medida, a regulação da educação superior colabora para a efetivação de políticas públicas de democratização do acesso à educação superior.

Nesse sentido, cabe consignar as seguintes conclusões fundamentadas ao longo do trabalho:

1. O Direito Educacional é uma disciplina jurídica em fase de consolidação, que na presente tese é conceituada como: um conjunto de normas jurídicas de direito público que disciplinam o direito à educação, bem como as relações jurídicas e a organização das atividades administrativas destinadas a sua efetivação, nos diversos níveis, por parte do Estado, por meio da prestação direta ou por meio da regulação da qualidade de sua prestação pela iniciativa privada. O presente trabalho buscou colaborar com o processo de consolidação dessa disciplina, a partir da sistematização da matéria relativa à regulação da educação superior.

2. O direito à educação deve ser considerado como direito fundamental social, por conta da ideologia contida na Constituição de 1988, de caráter social. Portanto, incumbe ao Estado, bem como à sociedade, a implementação de políticas públicas para a progressiva efetivação do direito à educação, em todos os níveis, com garantia de contínua melhoria dos padrões de qualidade.

3. A Constituição de 1988 estabelece, em seu artigo 209, que o ensino é livre à iniciativa privada, desde que sejam cumpridas as normas gerais da educação nacional, e a atividade seja submetida à autorização e avaliação de qualidade pelo Poder Público. Além disso, o texto constitucional fixa as bases de um sistema nacional de educação, envolvendo todas as entidades integrantes da Federação. 
4. A educação superior, embora não tratada de forma expressa pela Constituição como direito público subjetivo, pode vir a ser assim considerada no futuro, a exemplo do que ocorreu recentemente com o ensino médio, dado o caráter progressivo da efetivação dos direitos sociais.

5. Para expansão da oferta da educação superior, cabe ao Estado, principalmente: ampliar a oferta de educação superior pela rede pública; regular a expansão da oferta, zelando pela qualidade dos cursos e instituições públicas e privadas; e implementar políticas públicas de democratização do acesso à educação superior, por meio da criação de mecanismos de ingresso e permanência de estudantes de baixa renda.

6. A relação entre a educação de qualidade e o desenvolvimento nacional demanda a necessidade do aparelhamento do Estado para exercer sua função regulatória. Nesse aspecto, a educação superior de qualidade possui um relevante papel de indutor do desenvolvimento nacional, merecendo, dessa maneira, um tratamento jurídico adequado.

7. A Lei de Diretrizes e Bases da Educação regulamentou o artigo 209 da Constituição, estabelecendo os elementos fundamentais da atividade regulatória estatal em matéria de educação superior: (a) a necessidade de atos administrativos regulatórios, de caráter autorizativo; (b) a limitação de prazo e a necessidade de renovação de tais atos; (c) a existência de processo regular de avaliação para a expedição desses atos; (d) a possibilidade de saneamento de eventuais deficiências apontadas no processo de avaliação; e (e) a possibilidade da aplicação de sanções administrativas.

8. A educação superior, mesmo quando desenvolvida por particulares, caracteriza-se como serviço público, submetido a um regime jurídico que reflete as peculiaridades constitucionalmente estabelecidas no artigo 209, não se subordinando, assim, ao regime jurídico do artigo 173, tampouco ao do artigo 175. Por essa razão, a atividade regulatória no campo da educação superior tem por objeto a prestação de um serviço público fundamental para a efetivação de direitos sociais, mas, por outro lado, sofre a incidência de alguns aspectos relativos à regulação das atividades econômicas em sentido estrito.

9. O debate e a consolidação de sistemas nacionais de avaliação da educação superior estão fortemente presentes, no plano internacional, desde a década de 1990. Essa 
discussão influenciou diretamente a criação do Sistema Nacional de Avaliação da Educação Superior - SINAES, no Brasil, em 2004.

10. Para efetivar o preceito de garantia da qualidade na educação superior, foi necessária a consolidação de um arranjo jurídico, que estabelecesse a organização institucional e os instrumentos e critérios procedimentais. Esse conjunto de normas jurídicas produzidas a partir de 2004 é o que se denomina o novo marco regulatório da educação superior.

11. O Sistema Nacional de Avaliação da Educação Superior - SINAES, criado por meio da Lei $n^{\circ} 10.861 / 2004$, buscou assegurar um sistema integrado de avaliação que incluísse dimensões externas e internas, particulares e globais, observando critérios quantitativos e qualitativos, conferindo à avaliação da educação superior caráter sistêmico.

12. O marco regulatório da educação superior foi completado com a edição de normas infralegais, merecendo destaque o Decreto $\mathrm{n}^{\circ} 5.773 / 2006$ e a Portaria Normativa MEC no 40/2007.

13. O estabelecimento do marco regulatório da educação superior, em grande medida, por meio de atos normativos infralegais, tem sido compreendido pelo Poder Judiciário como regular exercício do poder regulamentar em relação às normas constitucionais e legais que condicionam a emissão de atos autorizativos à avaliação de qualidade.

14. Seguindo a tendência de procedimentalização da atividade administrativa, foi estabelecido um procedimento administrativo regulatório, por via eletrônica, necessário para a emissão de ato autorizativo, após a realização de avaliação de qualidade.

15. O procedimento administrativo regulatório da educação superior, baseado em indicadores de qualidade, se estabelece por meio de um trâmite trifásico: com análise documental, avaliação e decisão administrativa. Cada uma das fases apresenta a possibilidade de formulação de recurso administrativo.

16. O procedimento de supervisão da educação superior tem o objetivo de zelar pela conformidade de sua oferta com a legislação vigente e com os atos autorizativos, verificando possíveis ocorrências de irregularidades no funcionamento de instituições ou cursos superiores. 
17. A previsão de celebração de termo de saneamento de deficiências e de protocolo de compromisso indica forte tendência de fomento na atividade regulatória da educação superior, uma vez que oferece às instituições a possibilidade de ajustar com o Poder Público medidas visando à melhoria de qualidade.

18. Políticas públicas destinadas ao acesso à educação superior, como o ProUni e o FIES, devem manter e aprofundar sua relação com as atividades regulatórias deste nível educacional, pois, de forma articulada, constituem um fundamental mecanismo de democratização do acesso à educação superior, em padrões de qualidade satisfatórios.

19. O sistema regulatório da educação superior deve ser desenvolvido de modo a contribuir para a promoção da melhoria da qualidade associada a políticas de desenvolvimento regional.

20. De acordo com uma visão sistêmica do desenvolvimento de políticas educacionais, cabe ao sistema regulatório da educação superior um importante papel de garantia da efetivação do direito à educação em todos os seus níveis. 


\section{BIBLIOGRAFIA}

Adorno, Theodor W. Educação e emancipação. (tradução de Wolfgang Leo Maar). Rio de Janeiro: Paz e Terra, 2010.

Aguillar, Fernando Herren. Controle social dos serviços públicos. São Paulo: Max Limonad, 1999.

Alexy, Robert. Theorie der Grundrechte. Baden-Baden: Suhrkamp, 1994.

Alfinito, Solange. Educação superior no Brasil: análise do histórico recente (1994-2003). Brasília: INEP, 2007.

Almeida, Frederico Normanha Ribeiro de. "Avaliação de qualidade, profissionalização da docência e ensino jurídico". In Paulo Roberto Moglia Thompson Flores (org.). Desafios rumo à educação jurídica de excelência. Brasília: $\mathrm{OAB}$, Conselho Federal, Comissão Nacional de Ensino Jurídico, 2011, 133-142.

Alvarenga, José Eduardo de. “O serviço público”. In José Eduardo Martins Cardozo / João Eduardo Lopes Queiroz / Márcia Walquíria Batista dos Santos (orgs.). Curso de Direito Administrativo Econômico. Vol I. São Paulo: Malheiros, 2006, 319-374.

Aragão, Alexandre Santos de. "Regulação da Economia: conceito e características contemporâneas”. In José Eduardo Martins Cardozo / João Eduardo Lopes Queiroz / Márcia Walquíria Batista dos Santos (orgs.). Curso de Direito Administrativo Econômico. Vol III. São Paulo: Malheiros, 2006, 413-467.

Aragão, Alexandre Santos de. Direito dos serviços públicos. 2. ed. Rio de Janeiro: Forense, 2008.

Aragão, Alexandre Santos de. “Análise de Impacto Regulatório - AIR”, Revista de Direito Público da Economia 32 (2010), 9-15.

Araujo, Luiz Alberto David / Nunes Júnior, Vidal Serrano. Curso de direito constitucional. 9. ed. São Paulo: Saraiva, 2005.

Assis, Luiz Gustavo Bambini de. “A natureza jurídica do serviço prestado pelas instituições privadas de ensino: controvérsias sobre o tema”. In Nina Beatriz Stocco Ranieri (coord.). Direito à educação: aspectos constitucionais. São Paulo: EDUSP, 2009, 185-202. 
Barcellos, Ana Paula de. "Neoconstitucionalismo, direitos fundamentais e controle das políticas públicas”. Revista de Direito Administrativo 240 (2005), 83-103.

Barcellos, Ana Paula de. "Constitucionalização das políticas públicas em matéria de direitos fundamentais: o controle político-social e o controle jurídico no espaço democrático". Revista de Direito do Estado 3 (2006), 17-54.

Barreyro, Gladys Beatriz. Mapa do ensino superior privado. Brasília: INEP, 2008.

Barros, Marcus Aurélio de Freitas. Controle jurisdicional de políticas públicas: parâmetros objetivos e tutela coletiva. Porto Alegre: Sérgio Antonio Fabris, 2008.

Barroso, Luís Roberto / Barcellos, Ana Paula de. "O começo da História: a nova interpretação constitucional e o papel dos princípios no Direito brasileiro". In Virgílio Afonso da Silva (org.), Interpretação constitucional. São Paulo: Malheiros, $2005,271-316$.

Bercovici, Gilberto. Desigualdades regionais, Estado e Constituição. São Paulo: Max Limonad, 2003.

Bercovici, Gilberto. Constituição econômica e desenvolvimento: uma leitura a partir da Constituição de 1988. São Paulo: Malheiros, 2005.

Bercovici, Gilberto. "Desenvolvimento, Estado e Administração Pública”. In José Eduardo Martins Cardozo / João Eduardo Lopes Queiroz / Márcia Walquíria Batista dos Santos (orgs.). Curso de Direito Administrativo Econômico. Vol II. São Paulo: Malheiros, 2006, 19-39.

Bercovici, Gilberto. "Constituição econômica e dignidade da pessoa humana". Revista da Faculdade de Direito da Universidade de São Paulo 102 (2007), 457-467.

Bercovici, Gilberto / Massonetto, Luís Fernando. "Breve história da incorporação dos direitos sociais nas constituições democráticas brasileiras”. Revista do Departamento de Direito do Trabalho e da Seguridade Social 3 (2007), 61-84.

Bercovici, Gilberto / Massonetto, Luís Fernando. "Limites da regulação: esboço para uma crítica metodológica do "novo direito público da economia". Revista de Direito Público da Economia 25 (2009), 137-147. 
Bernheim, Carlos Tünnermann / Chauí, Marilena de Souza. Desafios da universidade na sociedade do conhecimento: cinco anos depois da conferência mundial sobre educação superior. Brasília: UNESCO, 2008.

Boaventura, Edivaldo M. “A constitucionalização da autonomia universitária”. Revista de Informação Legislativa 108 (1990), 297-308.

Boaventura, Edivaldo M. "A Constituição e a educação brasileira". Revista de Informação Legislativa 127 (1995), 29-42.

Boaventura, Edivaldo M. "Um ensaio de sistematização do direito educacional". Revista de Informação Legislativa 131 (1996), 31-57.

Boffo, Stefano / Moscati, Roberto. "Evaluation in the italian higher education system: many tribes, many territories... many godfathers". European Journal of Education 33 (3) (1998), 349-360.

Bonavides, Paulo. Curso de direito constitucional. 26 ed. São Paulo: Malheiros, 2011.

Bornmann, L. / Mittag, S. / Daniel, H. D. "Quality assurance in higher education - metaevaluation of multi-stage evaluation procedures in Germany". Higher Education 52 (2006), 687-709.

Boullosa, Alfredo Pérez. "Garantía de calidad en la enseñanza en el espacio europeo de educación superior”. Cuadernos de Integración Europea 2 (2005), 39-53.

Braga, Claudio Mendonça. “A Convenção da Unesco contra a discriminação no ensino e as ações afirmativas no Brasil". In Nina Beatriz Stocco Ranieri (coord.). Direito à educação: igualdade e discriminação no ensino. São Paulo: EDUSP, 2010, 92-106.

Braga, Claudio Mendonça. "Construção de novos parâmetros de avaliação qualitativa: a relação entre o Ministério da Educação e a Ordem dos Advogados do Brasil na atividade de regulação e supervisão dos cursos jurídicos”. In Paulo Roberto Moglia Thompson Flores (coord.). Desafios rumo à educação jurídica de excelência. Brasília: OAB, 2011, 127-131.

Braga, Claudio Mendonça. "O núcleo docente estruturante como elemento indicador da qualidade dos cursos jurídicos”. In Necessidades sociais e expectativas da educação jurídica de qualidade. Brasília: OAB, 2013, no prelo. 
Bucci, Maria Paula Dallari. Direito Administrativo e políticas públicas. São Paulo: Saraiva, 2002.

Bucci, Maria Paula Dallari. “O conceito de política pública em direito”. In Maria Paula Dallari (org.). Políticas públicas: reflexões sobre o conceito jurídico. São Paulo: Saraiva, 2006, 1-49.

Bucci, Maria Paula Dallari. "O art. 209 da Constituição 20 anos depois. Estratégias do Poder Executivo para a efetivação da diretriz da qualidade da educação superior”. In Gustavo Binenbojm / Daniel Sarmento / Cláudio Pereira de Souza Neto (orgs.). Vinte Anos da Constituição Federal de 1988. Rio de Janeiro: Lumen Juris, 2008, 781-807.

Bucci, Maria Paula Dallari. "Controle judicial de políticas públicas: possibilidades e limites". In Maria Victoria de Mesquita Benevides / Gilberto Bercovici / Claudineu de Melo (orgs.). Direitos Humanos, Democracia e República: homenagem a Fábio Konder Comparato. São Paulo: Quartier Latin, 2009, 693-711.

Bucci, Maria Paula Dallari. "Processo administrativo eletrônico e informação pública: o sistema e-MEC e o marco regulatório da educação superior”. 2013, no prelo.

Canotilho, José Joaquim Gomes. Direito constitucional. 6. ed. Coimbra: Almedina, 1993.

Canotilho, José Joaquim Gomes. Constituição dirigente e vinculação do legislador: contributo para a compreensão das normas constitucionais programáticas. 2. ed. Coimbra: Coimbra Editora, 2001.

Canotilho, José Joaquim Gomes. Direito constitucional e teoria da Constituição. 7. ed. Coimbra: Almedina, 2003.

Canotilho, José Joaquim Gomes. "Um olhar jurídico-constitucional sobre a judicialização da política. Revista de Direito Administrativo 245 (2007), 87-95.

Canotilho, José Joaquim Gomes. “O direito dos pobres no activismo judiciário”. In José Joaquim Gomes Canotilho / Marcus Orione Gonçalves Correia / Érica Paula Barcha Correia (coords.). Direitos fundamentais sociais. São Paulo: Saraiva, 2010, 33-35.

Cen, Yuhao / Ross, Heidi. "Chinese higher education and evaluation in context". Chinese Education and Society 42(2009), 3-7.

Claude, Richard Pierre / Andreopoulos, George (orgs.). (tradução de Ana Luiza Pinheiro), Educação em direitos humanos para o século XXI. São Paulo: EDUSP, 2007. 
Clève, Clèmerson Merlin. "O desafio da efetividade dos direitos fundamentais sociais". Revista da Academia Brasileira de Direito Constitucional 3 (2003), 289-300.

Comparato, Fábio Konder. Educação, Estado e Poder. São Paulo: Brasiliense, 1987.

Comparato, Fábio Konder. A afirmação histórica dos direitos humanos. 3. ed. São Paulo: Saraiva, 2003.

Comparato, Fábio Konder. "Ensaio sobre o juízo de constitucionalidade de políticas públicas”. Revista de Informação Legislativa 138 (1998), 39-48.

Cunha, Luiz Antônio. "Desenvolvimento desigual e combinado no ensino superior Estado e mercado", Educação \& Sociedade 25 (2004), 795-817.

Cunha, Luiz Antônio. A universidade temporã: o ensino superior, da Colônia à Era Vargas. 3. ed. São Paulo: UNESP, 2007.

Cury, Carlos Roberto Jamil. "O público e o privado na história da educação brasileira: concepções e práticas educativas”. In José Claudinei Lombardi / Mara Regina M. Jacomeli / Tânia Mara T. da Silva (orgs.). O público e o privado na história da educação brasileira: concepções e práticas educativas. Campinas: Autores Associados, Histedbr, Unisal, 2005, 3-28.

Dallari, Dalmo de Abreu. "Os direitos fundamentais na Constituição brasileira”. Revista da Faculdade de Direito da Universidade de São Paulo 88 (1993), 421-437.

Dallari, Dalmo de Abreu. Direitos humanos e cidadania. São Paulo: Editora Moderna, 1998.

Dallari, Dalmo de Abreu. "Educação e preparação para a cidadania". In Maria Victoria de Mesquita Benevides / Gilberto Bercovici / Claudineu de Melo (orgs.). Direitos Humanos, Democracia e República: homenagem a Fábio Konder Comparato. São Paulo: Quartier Latin, 2009, 323-345.

Dallari, Dalmo de Abreu. Elementos de Teoria Geral do Estado. 29. ed. São Paulo: Saraiva, 2010.

Declaração da Conferência Regional de Educação Superior na América Latina e no Caribe. Avaliação 14 (2009), 235-246. 
Di Pietro, Maria Sylvia Zanella. "Limites da função reguladora das Agencias diante do princípio da legalidade", in Maria Sylvia Zanella di Pietro (org.). Direito regulatório: temas polêmicos. São Paulo: Fórum, 2003, 27-60.

Di Pietro, Maria Sylvia Zanella. Direito administrativo. 25. ed. São Paulo: Atlas, 2012.

Diniz, Maria Helena. Compêndio de introdução à ciência do direito. 18 ed. São Paulo: Saraiva, 2006.

Dodds, Anneliese. "British and french evaluation of international higher education issues: an identical political reality?”. European Journal of Education 40 (2) (2005), 155 172.

Dória, Antônio de Sampaio. Direito constitucional: comentários à Constituição de 1946 (arts. 141, § 11 a 218). Vol. 4. São Paulo, Max Limonad, 1960.

Duarte, Clarice Seixas. "Direito público subjetivo e políticas educacionais". São Paulo em Perspectiva 18 (2004), 113-118.

Duarte, Clarice Seixas. "A educação como um direito fundamental de natureza social". Educação \& Sociedade 100 (2007), 691-713.

Dworkin, Ronald. Levando os direitos a sério. (tradução de Jefferson Luiz Camargo). 2 ed. São Paulo: Martins Fontes, 2007.

Español, Francisco Marcellán. “Criterios de garantía de calidad en educación superior: praxis europea". Educatio 23 (2005), 15-32.

Fernandes, Reynaldo / Pazello, Elaine Toldo / Leitão, Thiago Miguel Sabino de Pereira / Moriconi, Gabriela Miranda. Avaliação de cursos na educação superior: a função e a mecânica do Conceito Preliminar de Curso. Brasília: INEP, 2009.

Ferraz, Esther de Figueiredo. Alternativas da educação. Rio de Janeiro: José Olympio, 1976.

Ferraz, Esther de Figueiredo. "O Judiciário e os direitos humanos e sociais: notas para uma avaliação da justiça brasileira". In José Eduardo Faria (org.). Direitos Humanos, Direitos Sociais e Justiça. São Paulo: Malheiros, 1994, 94-112.

Ferraz Júnior, Tércio Sampaio. Introdução ao estudo do direito: técnica, decisão, dominação. 2. ed. São Paulo: Atlas, 1994. 
Ferreira, Nara Torrecilha. Programa Universidade para Todos: uma avaliação sobre efetividade da política pública. Dissertação de Mestrado. Faculdade de Economia, Administração, Contabilidade e Ciência da Informação e Documentação, Universidade de Brasília. Brasília, 2012.

Ferreira, Pinto. "Educação e Constituinte". Revista de Informação Legislativa 92 (1986), 171-194.

Gálvez, Inmaculada Egido / Haug, Guy. "La acreditación como mecanismo de garantía de la calidad: tendencias en el espacio europeo de educación superior". Revista Española de Educación Comparada 12 (2006), 81-112.

Garcia, Maria. "Educação, Cultura e Desporto, (arts. 205 a 217)". In Sônia Yuriko Kanashiro Tanaka (org.). Direito Constitucional. São Paulo: Malheiros, 2009, 178192.

Gomes, Magno Federici. "Educação superior privada como serviço de utilidade pública". Ensaio: Avaliação e Políticas Públicas em Educação (63) 2009, 263-292.

Gomes, Magno Federici. "Delimitação de atribuições educacionais: sistemas de ensino e competência constitucional". Revista Brasileira de Estudos Pedagógicos 230 (2011), 166-186.

Gordillo, Augustín. "La regulación económica y social". Revista Jurídica de Buenos Aires 3 (1998), 29-67.

Grau, Eros Roberto. “Atividade econômica e regulação”. Revista da Academia Brasileira de Direito Constitucional 3 (2003), 443-451.

Grau, Eros Roberto. A ordem econômica na Constituição de 1988. 14. ed. São Paulo: Malheiros, 2010.

Eros Roberto Grau. O direito posto e o direito pressuposto. 8. ed. São Paulo: Malheiros, 2012.

Grotti, Dinorá Adelaide Musetti. "Teoria dos Serviços Públicos e sua Transformação”. In Carlos Ari Sundfeld (coord.). Direito Administrativo Econômico. São Paulo: Malheiros, 2006, 39-71.

Haddad, Fernando. O Plano de Desenvolvimento da Educação: razões, princípios e programas. Brasília: INEP, 2008. 
Jacobs, Edgar Gastón. "Um instituto para regular o ensino superior". Gestão Universitária 308 (2012). Disponível em http://www.gestaouniversitaria.com.br/ index.php?option=com_content $\&$ view=article $\&$ id=27233:um-instituto-para-regularo-ensino-superior\&catid=316:308\&Itemid=21. Acesso em 08.12.2012.

Joaquim, Nelson. Direito educacional brasileiro: história, teoria e prática. Rio de Janeiro: Livre Expressão, 2009.

Justen Filho, Marçal. "Serviço público no direito brasileiro". In José Eduardo Martins Cardozo / João Eduardo Lopes Queiroz / Márcia Walquíria Batista dos Santos (orgs.). Curso de Direito Administrativo Econômico. Vol I. São Paulo: Malheiros, 2006, 375-407.

Justen Filho, Marçal. Curso de direito administrativo. 8. ed. Belo Horizonte: Fórum, 2012.

Kai, Jiang. "A critical analysis of accountability in higher education: its relevance to evaluation of higher education". Chinese Education and Society 42(2) (2009), 39-51.

Kant, Immanuel. Über Pädagogik. Königsberg: Friedrich Theodor Rinf, 1803.

Kelsen, Hans. Teoria geral do Direito e do Estado. (tradução de Luís Carlos Borges). São Paulo: Martins Fontes, 2005.

Lima, Licínio C. / Azevedo, Mário Luiz Neves de / Catani, Afrânio Mendes. "O processo de Bolonha, a avaliação da educação superior e algumas considerações sobre a universidade nova". Avaliação 13 (1) (2008), 7-36.

Lopes, José Reinaldo de Lima. "Direito subjetivo e direito sociais: o dilema do Judiciário no Estado Social de Direito". In José Eduardo Faria (org.). Direitos Humanos, Direitos Sociais e Justiça. São Paulo: Malheiros, 1994, 113-143.

Lourenço Filho, Manoel Bergstrom. Educação comparada. 3. ed. Brasília: MEC/INEP, 2004.

Marques Neto, Floriano Azevedo. "A nova regulação dos serviços públicos". Revista de Direito Administrativo 228 (2002), 13-29.

Marques Neto, Floriano Azevedo. "Concessão de serviço público sem ônus para o usuário”. In Luiz Guilherme da Costa Wagner Júnior. Direito Público - Estudos em homenagem ao Professor Adilson Abreu Dallari, Belo Horizonte, Del Rey, 2004, $331-351$. 
Miranda, Pontes de. Direito à educação. Rio de Janeiro: Alba Limitada, 1933.

Miranda, Jorge. Manual de Direito Constitucional. Tomo IV. 3. ed. Coimbra: Coimbra Editora, 2000.

Modesto, Paulo. "Reforma administrativa e marco legal das organizações sociais no Brasil”. Revista de Direito Administrativo 210 (1997), pp. 195-212.

Moreira, Vital. Auto-regulação profissional e Administração Pública. Coimbra: Almedina, 1997.

Moreira Neto, Diogo de Figueiredo. Direito Regulatório. Rio de Janeiro: Renovar, 2003.

Medauar, Odete. Direito administrativo moderno. 14. ed. São Paulo: RT, 2010.

Mello, Celso Antônio Bandeira de. Curso de direito administrativo. 27. ed. São Paulo: Malheiros, 2010.

Motta, Elias de Oliveira. Direito Educacional e educação no século XXI: com comentarios à nova Lei de Diretrizes e Bases da Educação Nacional. Brasilia: UNESCO, 1997.

Nader, Paulo. Introdução ao estudo do direito. 24. ed. Rio de Janeiro: Forense, 2004.

OCDE. Brasil: fortalecendo a governança para o crescimento. Relatório sobre a reforma regulatória. Casa Civil da Presidência da República, 2008.

Oyama, Lurdes Keiko. "O Direito à Educação na Constituição Portuguesa”. Revista de Direito Educacional 1 (2010), 171-205.

Pacheco, Eliezer / Ristoff, Dilvo I. Educação superior: democratizando o acesso. Brasília: INEP, 2004.

Paiva, Regina Garcia de. "Direito educacional: do fato para o Direito". In André Trindade (coord.). Direito educacional em uma ótica sistêmica. Curitiba: Juruá, 2010, 63-96.

Pannunzio, Eduardo. "O Judiciário e o direito à educação". In Nina Beatriz Stocco Ranieri (coord.). Direito à educação: aspectos constitucionais. São Paulo: EDUSP, 2009, 61-88.

Peci, Alketa. "Desenho de uma estratégia de implantação e institucionalização da AIR". In Jadir Dias Proença (org.). PRO-REG: Contribuições para melhoria da qualidade da Regulação no Brasil. Vol 1. Brasília: Semear Editora/Presidência da República, 2010, 17-96. 
Pessôa Valente, Patrícia Rodrigues. Análise de Impacto Regulatório: uma ferramenta à disposição do Estado. Dissertação de Mestrado. Departamento de Direito do Estado da Faculdade de Direito, Universidade de São Paulo. São Paulo, 2010.

Piovesan, Flávia. "Justiciabilidade dos direitos sociais e econômicos: desafios e perspectivas”. In José Joaquim Gomes Canotilho / Marcus Orione Gonçalves Correia / Érica Paula Barcha Correia (coords.). Direitos fundamentais sociais. São Paulo: Saraiva, 2010, 53-69.

Pó, Marcos Vinícius / Abrúcio, Fernando Luiz. "Desenho e funcionamento dos mecanismos de controle e accountability das agências reguladoras brasileiras: semelhanças e diferenças". Revista Brasileira de Administração Pública 40 (2006), 679-698.

Ranieri, Nina Beatriz Stocco. Autonomia universitária. São Paulo: EDUSP, 1994.

Ranieri, Nina Beatriz Stocco. Educação Superior, Direito e Estado: na Lei de Diretrizes e Bases (Lei $n^{o}$ 9.394/96). São Paulo: Editora da Universidade de São Paulo, Fapesp, 2000.

Ranieri, Nina Beatriz Stocco. "Os Estados e o direito à educação: comentários acerca da jurisprudência do Supremo Tribunal Federal". In Nina Beatriz Stocco Ranieri (coord.). Direito à educação: aspectos constitucionais. São Paulo: EDUSP, 2009, 39-59.

Ribeiro, Darcy. A universidade necessária. 5. ed. São Paulo, Paz e Terra, 1991.

Rocher, Ignacio Javier Alfaro. "El Espacio Universitario Europeo: entre la autonomía, la diversidad y la convergência”. Cuadernos de Integración Europea 2 (2005), 3-15.

Salomão Filho, Calixto. Regulação da atividade econômica: princípios e fundamentos jurídicos. 2. ed. São Paulo: Malheiros, 2008.

Sant'Ana, Diogo de. "Conjuntura da regulação no Brasil: conflitos e convergência". In Mario Gomes Schapiro (coord.). Direito econômico regulatório. São Paulo: Saraiva, 2010, 365-392.

Sarlet, Ingo Wolfgang. "O papel da jurisdição constitucional na realização do Estado Social”. Revista da Academia Brasileira de Direito Constitucional 3 (2003), 355365.Sarlet, Ingo Wolfgang. "Os direitos sociais como direitos fundamentais: contributo para um balanço aos vinte anos da Constituição Federal de 1998”. In 
Gustavo Binenboj / Daniel Sarmento / Cláudio Pereira de Souza Neto (orgs.). Vinte Anos da Constituição Federal de 1988. Rio de Janeiro: Lumen Juris, 2008, 479-510.

Schirato, Vitor Rhein. Livre iniciativa nos serviços públicos. Belo Horizonte, Fórum, 2012.

Severino, Antônio Joaquim. "Expansão do ensino superior: contextos, desafios, possibilidades". Avaliação 14 (2) (2009), 253-266.

Sifuentes, Mônica. "Direito da educação e função dos juízes”. In António Pedro Barbas Homem (coord.). Temas de direito da educação. Coimbra: Almedina, 2006, 41-44.

Sifuentes, Mônica. Direito fundamental à educação. 2. ed., Porto Alegre: Núria Fabris Editora, 2009.

Silva, José Afonso da. Aplicabilidade das normas constitucionais. 6. ed. São Paulo: Malheiros, 2003.

Silva, José Afonso da. Curso de direito constitucional positivo. 32. ed. São Paulo: Malheiros, 2010.

Silva, José Afonso da. Comentário contextual à Constituição. 7. ed. São Paulo: Malheiros, 2010.

Silva, Virgílio Afonso da. "O Judiciário e as políticas públicas: entre transformação social e obstáculo à realização dos direitos sociais”. In Cláudio Pereira de Souza Neto / Daniel Sarmento (coord.). Direitos sociais: fundamentos, judicialização e direitos sociais em espécie. Rio de Janeiro: Lumen Juris, 2008, 587-599.

Silva Júnior, João dos Reis / Sguissardi, Valdemar. "A nova lei de educação superior: fortalecimento do setor público e regulação do privado/mercantil ou continuidade da privatização e mercantilização do público?”. Revista Brasileira de Educação 29 (2005), 5-28.

Silveira, Vladmir Oliveira da / Nohara, Irene Patrícia. "Supervisão do ensino superior de direito no contexto federativo e complexidades do controle da pós-graduação stricto sensu - tensões do discurso do desempenho em face do objetivo da democratização", Revista de Direito Educacional 5 (2012), pp. 277-292.

SINAES - Sistema Nacional de Avaliação da Educação Superior: da concepção à regulamentação. 4. ed. Brasília: INEP, 2007. 
Siqueira, Ângela C. de. "A regulamentação do enfoque comercial no setor educacional via OMC/GATS”. Revista Brasileira de Educação 26 (2004), 145-156.

Sobrinho, José Dias. “Avaliação e transformações da educação superior brasileira (19952009): do Provão ao SINAES”. Avaliação 15 (1) (2010), 195-224.

Souza Neto, Claudio Pereira de. "A justiciabilidade dos direitos sociais: críticas e parâmetros". In Cláudio Pereira de Souza Neto / Daniel Sarmento (coord.). Direitos sociais: fundamentos, judicialização e direitos sociais em espécie. Rio de Janeiro: Lumen Juris, 2008, 515-551.

Sousa, Eliane Ferreira de. Direito à educação: requisito para o desenvolvimento do país. São Paulo: Saraiva, 2010.

Sundfeld, Carlos Ari. Direito Administrativo Ordenador. São Paulo: Malheiros, 1993.

Sundfeld, Carlos Ari. Fundamentos de direito público. 5. ed. São Paulo: Malheiros, 2012.

Tavares, André Ramos. "A intervenção do Estado no domínio econômico". In José Eduardo Martins Cardozo / João Eduardo Lopes Queiroz / Márcia Walquíria Batista dos Santos (orgs.). Curso de Direito Administrativo Econômico. Vol II. São Paulo: Malheiros, 2006, 173-218.

Tavares, André Ramos. "Direito Fundamental à educação". In Cláudio Pereira de Souza Neto / Daniel Sarmento (coord.). Direitos sociais: fundamentos, judicialização e direitos sociais em espécie. Rio de Janeiro: Lumen Juris, 2008, 771-787.

Teixeira, Anísio. A universidade de ontem e de hoje. Rio de Janeiro: EdUERJ, 1998.

Terrazas, Fernanda Vargas, "O Poder Judiciário como voz institucional dos pobres: o caso das demandas judiciais de medicamentos". Revista de Direito Administrativo 253 (2010), 79-115.

Tojal, Sebastião Botto de Barros. "Controle judicial da regulamentação de políticas públicas”. Revista da Academia Brasileira de Direito Constitucional 3 (2003), 185194.

Trindade, André / Mazzari Júnior, Edval Luiz. "Autonomia universitária e direito educacional". In André Trindade (coord.). Direito universitário e educação contemporânea. Porto Alegre: Livraria do Advogado, 2009, 9-84. 
UNESCO. Reforms and Innovation in Higher Education in Some Latin American and Caribbean Countries, 1998-2003. Caracas: UNESCO-IESALC, 2003.

Wang, Daniel Wei Liang. "Escassez de recursos, custos dos direitos e reserva do possível na jurisprudência do STF”. Revista Direito GV 4(2) (2008), 539-568.

Wang, Daniel Wei Liang. "Poder Judiciário e políticas públicas de saúde: participação democrática e equidade”. Cadernos Gestão Pública e Cidadania 54 (2009), 51-87.

Wang, Daniel Wei Liang / Palma, Juliana Bonacorsi de / Colombo, Daniel Gama e. "Revisão judicial dos atos das agências reguladoras: uma análise da jurisprudência brasileira”. In Mario Gomes Schapiro (coord.). Direito econômico regulatório. São Paulo: Saraiva, 2010, 269-328.

Weber, Silke. "Avaliação e regulação da educação superior: conquistas e impasses". Educação \& Sociedade 113 (2010), 1247-1269. 


\section{ANEXO: Legislação e normas pertinentes à regulação da educação superior}

\section{Legislação ordinária}

Lei n ${ }^{\circ}$ 4.024, de 20 de dezembro de 1961 (Conselho Nacional de Educação)

Lei ${ }^{\circ} 5.540$, de 28 de novembro de 1968 (escolha de dirigentes)

Lei n ${ }^{\circ} 9.131$, de 24 de novembro de 1995 (organização das mantenedoras)

Lei $\mathrm{n}^{\circ}$ 9.394, de 20 de dezembro de 1996 (LDB)

Lei $\mathrm{n}^{\circ}$ 9.784, de 29 de janeiro de 1999 (processo administrativo)

Lei $\mathrm{n}^{\circ}$ 9.870, de 23 de novembro de 1999 (anuidades escolares)

Lei $\mathrm{n}^{\circ} 10.260$, de 12 de julho de 2001 (FIES)

Lei $\mathrm{n}^{\mathrm{o}}$ 10.861, de 14 de abril de 2004 (SINAES)

Lei $\mathrm{n}^{\circ}$ 10.870, de 19 de maio de 2004 (taxa de avaliação)

Lei ${ }^{\circ}$ 11.096, de 13 de janeiro de 2005 (PROUNI)

Lei ${ }^{\circ} 11.128$, de 28 de junho de 2005 (adesão ao PROUNI)

Lei $n^{\circ} 11.507$, de 20 de julho de 2007 (auxílio de avaliação educacional)

Lei $\mathrm{n}^{\mathrm{o}} 12.527$, de 18 de novembro de 2011 (acesso a informações)

\section{Decretos}

Decreto $n^{\circ} 5.773$, de 9 de maio de 2006 (avaliação, regulação e supervisão)

Decreto $n^{\circ}$ 5.786, de 24 de maio de 2006 (centros universitários)

Decreto $\mathrm{n}^{\circ}$ 7.690, de 2 de março de 2012 (estrutura regimental do MEC)

\section{Portarias Normativas - Ministério da Educação}

Portaria Normativa $\mathrm{n}^{\circ} 1$, de 10 de janeiro de 2007 (ciclo avaliativo)

Portaria Normativa $\mathrm{n}^{\circ}$ 40, de 12 de dezembro de 2007 (e-MEC) 
Portaria Normativa $\mathrm{n}^{\circ}$ 6, de 14 de março de 2012 (ENADE 2012)

\section{Portarias - Ministério da Educação}

Portaria $\mathrm{n}^{\mathrm{o}}$ 1.741, de 12 de dezembro de 2011 (indicadores - instrumentos de avaliação)

Portaria $\mathrm{n}^{\circ}$ 1.006, de 10 de agosto de 2012 (PARES)

\section{Resoluções - Câmara de Educação Superior do Conselho Nacional de Educação}

Resolução CNE/CES no 2, de 18 de junho de 2007 (carga horária mínima e duração de cursos)

Resolução CNE/CES nº 3, de 2 de julho de 2007 (conceito de hora-aula)

Resolução CNE/CES n ${ }^{\circ}$ 7, de 28 de novembro de 2008 (denominações e siglas de IES)

Resolução CNE/CES no 1, de 20 de janeiro de 2010 (credenciamento e recredenciamento de centros universitários)

Resolução CNE/CES no 3, de 14 de outubro de 2010 (credenciamento e recredenciamento de universidades)

Resolução CNE/CES n ${ }^{\circ}$ 6, de 8 de julho de 2011 (delegação de competências)

\section{Resolução - Comissão Nacional de Avaliação da Educação Superior}

Resolução CONAES nº 1, de 17 de junho de 2010 (núcleo docente estruturante)

\section{Resolução - Conselho Nacional de Saúde}

Resolução CNS no 350, de 09 de junho de 2005 (cursos na área de saúde)

\section{Instrução Normativa - Ordem dos Advogados do Brasil}

Instrução Normativa $\mathrm{OAB}$ n $^{\circ}$ 1, de 06 de dezembro de 2008 (cursos de Direito)

\section{Editais - Secretaria de Regulação e Supervisão da Educação Superior}

Edital SERES/MEC nº 01, de 09 de agosto de 2011 (migração de sistemas)

Edital SERES/MEC nº 1, de 14 de agosto de 2012 (migração de sistemas) 